\title{
DEFENSE WASTE PROCESSING FACILITY: \\ REPORT OF TASK FORCE ON OPTIONS TO MITIGATE THE EFFECT OF NITRITE ON DWPF OPERATIONS (U)
}

\section{SAVANNAH RIVER SITE 200-S AREA}

Author:

J. C. Marek

Contributors:

D. D. Walker

D. H. McGuire

J. W. Nelson/Bechtel National

P. E. Zapp

D. F. Brown

D. F. Bickford

P. D. D'Entremont

J. F. McGlynn

Editor:

D. Randall

March 1992

Authorized Derivative Classifier

LPan - 2an

C. T. Randali, 704T 


\section{DISCLAIMER}

This report was prepured by Westinghouse Savannah River Company (WSRC) for the United States Department of Energy under Contract No. DE-ACO9-89SR18035 and is an sccount of work performed under that contract. Neither the United States Department of Energy, nor WSRC, nor any of their employees makes any warranty, expressed or implied, or assumes any legal liability or responsibility for the eccuracy, completeness, or usefulness of any information, apparatus, or product or process disclosed herein or represents that its use will not infringe privately owned rights. Reference herein to any specific commercial produch, process, or service by tradematk, name, manufacturer or otherwise does not necessarily constitute or imply endorsement, recommendation, or favoring of same by WSRC or by the United States Covernment or any agency thereof. The views and opinions of the authors expressed herein do not necessarily state or reflect those of the United States Government or any agency thereof. 


\section{Distribution:}

P. M. Hekman, Jr., 703-A

L. C. Sjostrom, 703-A

A. L. Schwallie, 703-A

D. B. Amerine, 704-S

M. A. Baich, 704-T

R. T. Begley, 773-A

D. F. Bickford, 773-A

N. C. Boyter, 703-A

D. F. Brown, 703-H

J. T. Carter, 704-1T

P. D. d'Entremont, 703-H

R. E. Eibling, 704-T

D. L. Fish, 773-A

S. T. Goforth, 773-A

R. W. Harral, 703-H

D. W. Harrison, 704-S

E. W. Holtzscheiter, 773-A

C. W. Hsu, 704-1T

R. A. Jacobs, 704-T

A. L. Kielpinski, 773-11A

L. F. Landon, 704-T

L. M. Lee, 704-T

B. L. Lewis, 703-H

J. C. Marek, 704-T

J. C. Marra, 773-A

J. F. McGlynn, 773-A

D. H. McGuire, 704-27S

J. F. Ortaldo, 704-S

L. M. Papouchado, 773-A

C. Peckinpaugh, 703-A

M. J. Plodinec, 773-A

C. T. Randall, 704-T

D. Randall, 773-42A

H. E. Shook, 704-1T

W. E. Stevens, 773-43A

W. L. Tamosaitis, 773-A

W. J. Vetch, WYATT

D. D. Walker, 773-A

G. T. Wright, 703-H

P. E. Zapp, 773-A

SRTC Records (4) 
DEFENSE WASTE PROCESSING FACILITY:

REPORT OF TASK FORCE ON OPTIONS TO MITIGATE THE

EFFECT OF NITRITE ON DWPF OPERATIONS (U)

\section{ABSTRACT}

The possibility of accumulating ammonium nitrate (an explosive) as well as organic compounds in the DWPF Chemical Processing Cell Vent System was recently discovered. A task force was therefore organized to examine ways to avoid this potential hazard. Of thirty-two processing/engineering options screened, the task force recommended five options, deemed to have the highest technical certainty, for detailed development and evaluation:

- Radiolysis of nitrite in the tetraphenylborate precipitate slurry feed in a new corrosion-resistant facility.

- Construction of a Late Washing Facility for precipitate washing before transfer to the DWPF.

- $\quad$ "Just-in-Time" precipitation.

- Startup Workaround by radiolysis of nitrite in the existing corrosion-resistant Pump Pit tanks.

- Ammonia venting and organics separation in the DWPF.

Estimated costs and schedules are included in this report. 
Revision 0

BLANK 
WSRC-TR-92-67

Revision 0

DEFENSE WASTE PROCESSING FACILITY:

REPORT OF TASK FORCE ON OPTIONS TO MITIGATE THE

EFFECT OF NITRITE ON DWPF OPERATIONS (U)

CONTENTS

1.0 EXECUTIVE SUMMARY

2.0 INTRODUCTION

2.1 Process Description

2.2 Discovery of Problem

3.0 SUMMARY

3.1 Task Force Studies

3.2 Task Force Recommendations

3.2.1 Recommended Options for the Chemical Process Cell

3.2.2 Recommended Long-Range Options for the Salt Process Cell

3.2.3 Recommended Short-Term Workaround Option

3.2.4 Actions Recommended for Immediate Implementation

3.2.5 Results from Immediate Actions

4.0 SCHEDULE AND COST OF RECOMMENDED OPTIONS

4.1 Salt Process Cell Options

4.1.1 Radiolysis Facility

4.1.2 Late Washing Facility

4.1.3 Just-in-Time Precipitation

4.1.4 Startup Workaround by Pump Pit Radiolysis

4.1.5 Ammonia Venting and Organics Separation

4.2 Chemical Process Cell Options

4.2.1 Ammonia Scrubbers

5.0 NITRITE AND AMMONIUM ION CHEMISTRY

5.1 Nitrite Chemistry in the Tank Farm

5.2 Nitrite Chemistry in the DWPF

5.3 Sources of Ammonium Ion

6.0 DESCRIPTION OF OPTIONS WITH HIGHEST TECHNICAL CERTAINTY

6.1 Salt Process Cell: Radiolysis Facility

6.1.1 Approach

6.1.2 Process Details

6.1.3 Technical Certainty Rating

6.1.4 Technical Certainties and Benefits

6.1.5 Technical Uncertainties and Risiks

6.2 Late (or Final) Washing

6.2.1 Approach

6.2.2 Process Details

6.2.3 Technical Certainty Rating

6.2.4 Technical Certainties and Benefits 
6.2.5 Technical Uncertainties and Risks

6.3 "Just In Time" Precipitation

6.3.1 Approach

6.3.2 Process Details

6.3.3 Technical Certainty Rating

6.3.4 Technical Certainties and Benefits

6.3.5 Technical Uncertainties and Risks

6.4 Chemical Process Cell: Ammonia Scrubbers

6.4.1 Approach

6.4.2 Process Details

6.4.3 Technical Certainty Rating

6.4.4 Technical Certainties and Benefits

6.4.5 Technical Uncertainties and Risks

6.5 Workaround Option for Startup: Pump Pit Radiolysis

6.5.1 Approach

6.5.2 Process Details

6.5.3 Technical Certainty Rating

6.5.4 Technical Certainties and Benefits

6.5.5 Technical Uncertainties and Risks

7.0 DESCRIPTION OF OTHER OPTIONS FOR SALT PROCESS CELL

7.1 SPC Modifications to Mitigate Ammonium Nitrate by Ammonia Vent

7.1.1 Approach

7.1.2 Process Details

7.1.3 Technical Certainty Rating

7.1.4 Technical Certainties and Benefits

7.1.5 Technical Uncertainties and Risks

7.2 Physical Separation of Organic-Coated Solids

7.2.1 Approach

7.2.2 Process Details

7.2.3 Technical Certainty Rating

7.2.4 Technical Certainties and Benefits

7.2.5 Technical Uncertainties and Risks

\subsection{GENERIC RECOMMENDATIONS}

8.1 Reducing Nitrite in the Precipitate

8.2 Reworking the Precipitate

8.3 Mitigation of Ammonium Nitrate Accumulation

8.4 Noble Metal Testing

8.5 Organic High-Boiler Carryover in the Salt Process Cell

8.6 Improving Attainment During Pump-Pit Workaround

8.7 DWPF Recycle to Tank Farm

\subsection{SUMMARY OF ALL OPTIONS CONSIDERED}

9.1 Promising Options

9.1.1 Options That Eliminate Ammonium Formation in the SPC

Option 1: Radiolysis of Nitrite 


\author{
Option 2: Late Washing \\ 9.1.2 Option That Deals with Ammonium Formed in the SPC \\ Option 3: Evolution of Ammonia \\ 9.1.3 SPC Options That Close-Couple ITP to DWPF Operations \\ Option 4: "Just-in-Time" Precipitation in New Facility \\ Option 5: "Just-in-Time" Precipitation in Tanks 48, 49 \\ 9.1.4 Options That Deal with Ammonia Evolved in the CPC \\ Option 6: Ammonia Gas Scrubbers, PVV Filter Flush \\ Option 7: Continuous HEME Spray for FAVC \\ 9.1.5 Option That Prevents Formation of Ammonium in the CPC \\ Option 8: Use of Nitric Acid in SRAT \\ 9.1.6 Option That Reduces Organic Carryover in the CPC \\ 9.2 Rejected Options \\ Option 9: Separation of Organic-Coated Solids \\ Option 10: Steam/Cooling Jackets Around Vent Jumpers \\ Option 11: Absorber for Ammonium (in Liquid) or Ammonium \\ Nitrate (in Gas) \\ Option 12: Explosion-Proof Design \\ Option 13: Flush System for PVV Header \\ Option 14: Catalytic Combustion of Ammonia \\ Option 15: CPC Vent Reroute \\ Option 16: Ammonia Gas Scrubber in SPC Vent \\ Option 17: Acidic pH Maintained in SRAT \\ Option 18: PHA Dewatered in PR \\ Option 19: Replace HAN with Sulfamate \\ Option 20: Supplement HAN with Sulfamate \\ Option 21: Reduce HAN Usage \\ Option 22: Use No HAN \\ Option 23: Eliminate Nitrite by Chemical Oxidizer or Electrolytic \\ Cell \\ Option 24: Increase Concentration of Precipitation Solids, \\ Redilute in PR \\ Option 25: Minimize Nitrite by Additional Washing \\ Option 26: Minimize Nitrite by Cooling Waste Tanks \\ Option 27: Minimize Nitrite by More Frequent but Smaller \\ Additions \\ Option 28: Supplement Nitrite with Hydroxide \\ Option 29: Use Additional Washing/Cooling to Eliminate Need for \\ Inhibitor \\ Option 30: Use Alternative/Supplemental Inhibitor (Chromate, \\ Molybdate, Borate) \\ Option 31: Use Non-Chemical Inhibitor (Cathodic Protection) \\ Option 32: Set Corrosion Allowance for Tanks 48 and 49
}




\section{REFERENCES}
APPENDIX A. Nitrite Task Force Charter
APPENDIX B. Task Force Rating Criteria and Assessment Process
APPENDIX C. Pitting Corrosion and Its Inhibition in Carbon-Steel Waste Tanks
APPENDIX D. Radiolysis of Nitrate and Nitrite Solutions
APPENDIX E. Summary of Option Project Schedule Estimates
APPENDIX F. Sizing the Nitrite Radiolysis Facility and Attainment Estimates for the Pump-Pit Startup Workaround
APPENDIX G. Conceptual Design of a Nitrite Radiolysis Facility
APPENDIX H. Overhead Slides From Task Force Presentation

GLOSSARY 
Ammonium nitrate (a known explosive) and non-polar organics accumulated in the process vessel vent system of the Integrated DWPF Melter System (IDMS) during preparations of simulated melter feeds. The accumulated material created a potential safety hazard and operational problems (e.g., filter pluggage) in the pilot facility at TNX. These technical problems result from the addition of sodium nitrite to the soluble radioactive waste to inhibit pitting corrosion of the carbon-steel processing tanks (Tanks 48 and 49) during In-Tank Precipitation. The impact of nitrite must be aggressively resolved to ensure a safe and timely startup of the Defense Waste Processing Facility (DWPF).

A Task Force was chartered on December 12, 1991 (Appendix A) to rapidly evaluate and supplement all potential options for mitigating or eliminating the impact of nitrite on DWPF operations. Each option was evaluated for technical feasibility and risk, schedule impact (assuming 6/94 startup of radioactive operations in the DWPF), and cost impact. The recommendations were presented to R. T. Begley and N. C. Boyter on 12/19/91.

Under the current DWPF process chemical flowsheet, the primary source of ammonium ion will be the aqueous product produced in the Salt Process Cell (SPC). At projected levels of nitrite $(S 0.08 \mathrm{M})^{*}$ in the washed precipitate feed to DWPF, hydroxylamine nitrate (HAN) is needed in the DWPF Precipitate Hydrolysis Process to minimize production of non-polar organics and tars from the nitrite. However, HAN also produces ammonium ion that is eventually transferred from the SPC to the Chemical Process Cell (CPC) when the precipitate hydrolysis aqueous product (PHA) is blended with the acidified sludge.

The $\mathrm{pH}$ of the acidified sludge waste rises during the SRAT process. This phenomenon is probably accelerated by noble-inatal-catalyzed dehydrogenation of the formic acid used during melter feed preparation.[1] The $\mathrm{pH}$ rise promotes evolution of ammonia from the processing vessels into the vent system. Ar:nonium ion is also formed during the sludge adjustment with formic acid, presumably by reactions of hydrogen and nitrate catalyzed by noble metals. At the design-basis nitrite content of precipitate feed $(0.20 \mathrm{M})$, it is estimated $620 \mathrm{lbs}$ of ammonium nitrate could accumulate in the DWPF CPC process vessel vent system per melter feed batch. It is estimated that the PHA/HAN source accounts for about $90 \%$ and the CPC generation of ammonium accounts for about $10 \%$ of the total potential ammonium.

For highest technical certainty of mitigating ammonium from the PHA source term, the task force recommends installing a corrosion-resistant (Type 304L or Type 316 stainless steel) facility to reduce the nitrite content of the washed precipitate feed to $50.01 \mathrm{M}$ and operation of the Salt Process Cell without HAN. Bench-scale experiments indicate precipitate hydrolysis could be performed without HAN at feed nitrite levels $<0.01 \mathrm{M}$. The new facility should be designed for maximum flexibility to reduce the nitrite concentration to $\leq 0.01 \mathrm{M}$ by any of three identified technologies: radiolytic nitrite destruction, late (or final) washing of the stored precipitate, or "Just In Time" (JIT) precipitation. Which of these three technologies is of highest technical certainty is not clear at this time. SRL priorities should be re-aligned to address the technical uncertainties associated with these three options.

Radiolytic nitrite destruction offers several attractive benefits: a straightforward workaround to meet the 6/94 radioactive operation startup date, minimal complexity of operations, minimal changes in the existing Tank Farm and DWPF processing plans, and no change in the degree to which the Tank Farm operations are coupled to DWPF. The radiolysis would destroy the nitrite during storage of the washed precipitate slurry in the facility. Depending on several factors (extent

* Revised downward from $0.2 \mathrm{M}$, the design basis concentration.

M920208 
of precipitate washing in Tank 48, storage temperature in Tank 49, initial nitrite content of washed precipitate, radionuclide content, preliminary data for nitrite destruction (Appendix D), etc.), the projected additional storage capacity could range from 160,000 gallons to 570,000 gallons.

Assuming one of the above technologies is selected for long-term implementation, the schedule for the new facility would not meet the 694 startup date for DWPF radioactive operation. As a "workaround", the existing pump pit tanks and the Precipitate Reactor Feed Tank could be used to radiolytically destroy nitrite and meet the $6 / 94$ startup date while accepting a significant attainment penalty. However, it is further recommended that a new task force be chartered to assess In-Tank Precipitation and DWPF operational improvements to minimize the attainment penalty with this option and identify more attractive startup workarounds.

The Task Force recommends an aggressive development effort on a nitric acid sludgeadjustment process because an estimated $10 \%$ of the potential ammonium nitrate is generated in the current CPC melter feed preparation process. Bench-scale scoping experiments indicate that no ammonium ion is formed and hydrogen production is greatly reduced when simulated sludge waste with noble metals is treated with nitric acid instead of formic acid. The Task Fonce recommends designing and installing scrubber jumpers on the exhaust line from the Formic Acid Vent Condenser (FAVC) and the vent line of the Recycle Collection Tank (RCT), to mitigate ammonium nitrate generation and accumulation in the CPC with the current formic acid sludge flowsheet. The scrubbers should be supplemented with periodic inspection and cleaning of FAVC jumpers and flooding of the Process Vessel Vent System filter. 


\subsection{PROCESS DESCRIPTION}

A simplified process diagram is shown in Figure 1. Sludge waste will be transferred from storage to specially equipped waste processing tanks and washed to remove soluble salts. The washed sludge will be stored in the Tank Farm and fed in small batches to the Sludge Receipt Adjustment Tank (SRAT) in the DWPF Chemical Process Cell (CPC). In the SRAT, formic acid is added and the sludge is boiled to reduce metal oxides and remove mercury by steam-stripping.

The soluble waste in the Tank Farm will be decontaminated by the In-Tank Precipitation (ITP) process, and the decontaminated salt solution will be converted into Saltstone at $Z$ Area. The concentrated radioactive organic precipitate (primarily potassium tetraphenylborate, KTPB) from the ITP process will be stored in Tank 49 until it is fed in small batches to the Salt Process Cell (SPC) in the DWPF. In the Precipitate Reactor (PR) of the SI'C, the precipitate will be reacted with formic acid and a copper catalyst to remove the aromatic carbon by converting it primarily to benzene (organic waste). The organic will be stripped, decontaminated, and recovered for eventual disposal, possibly by incineration. The aqueous hydrolysis product (Precipitate Hydrolysis Aqueous, or PHA) contains the radioactive elements (primarily cesium-137 and barium 137) and will be sent to the Precipitate Reactor Bottoms Tank (PRBT) for eventual transfer to the SRAT. In the SRAT, the PHA will be combined with the sludge vaste and boiled down to reduce the water content of the waste slurry.

The combined Sludge/PHA slurry will then be trans tr: ed to the Slurry Mix Evaporator (SME). In the SME, glass frit will be added and the slurry will be further concentrated by boiling off more water. The material will then be sampled and analyzed for process control of glass quality before it is transferred to the Melter Feed Tank (MFT) and eventually to the DWPF glass melter.

\subsection{DISCOVERY OF PROBLEM}

Pilot-scale operations at TNX use the Precipitate Hydrolysis Experimental Facility (PHEF) to produce PHA for processing tests in the Integrated DWPF Melter System (IDMS). The IDMS simulates both the SRAT and SME operations in the DWPF Chemical Process Cell with a single tank and the glass melter. During recent pilot-scale operations, ammonium nitrate (an explosive) and organic compounds accumulated in the IDMS SRAT/SME vessel vent system (not to be confused with the melter off-gas system). The accumulation was detected after loss of instrumentsampling capability on the vent lines due to pluggage of the small sampling lines. Further investigation revealed significant deposits consisting of ammonium nitrate mixed with organic solids in the ventilation lines. The accumulation of ammonium nitrate was observed after processing simulated sludge that included noble metals (palladium, rhodium, and ruthenium).[1]

The implications for the feed preparation processes of the DWPF are:

- a potential explosion hazard from the accumulation of ammonium nitrate, and

- a potentially severe attainment reduction by the accumulation of organic solids.

As a result of these findings, a task force was chartered on December 12, 1991 (Appendix A) to develop and evaluate options to mitigate or eliminate the impact of sodium nitrite on the DWPF. 
WSRC-TR-92-67

Revision 0

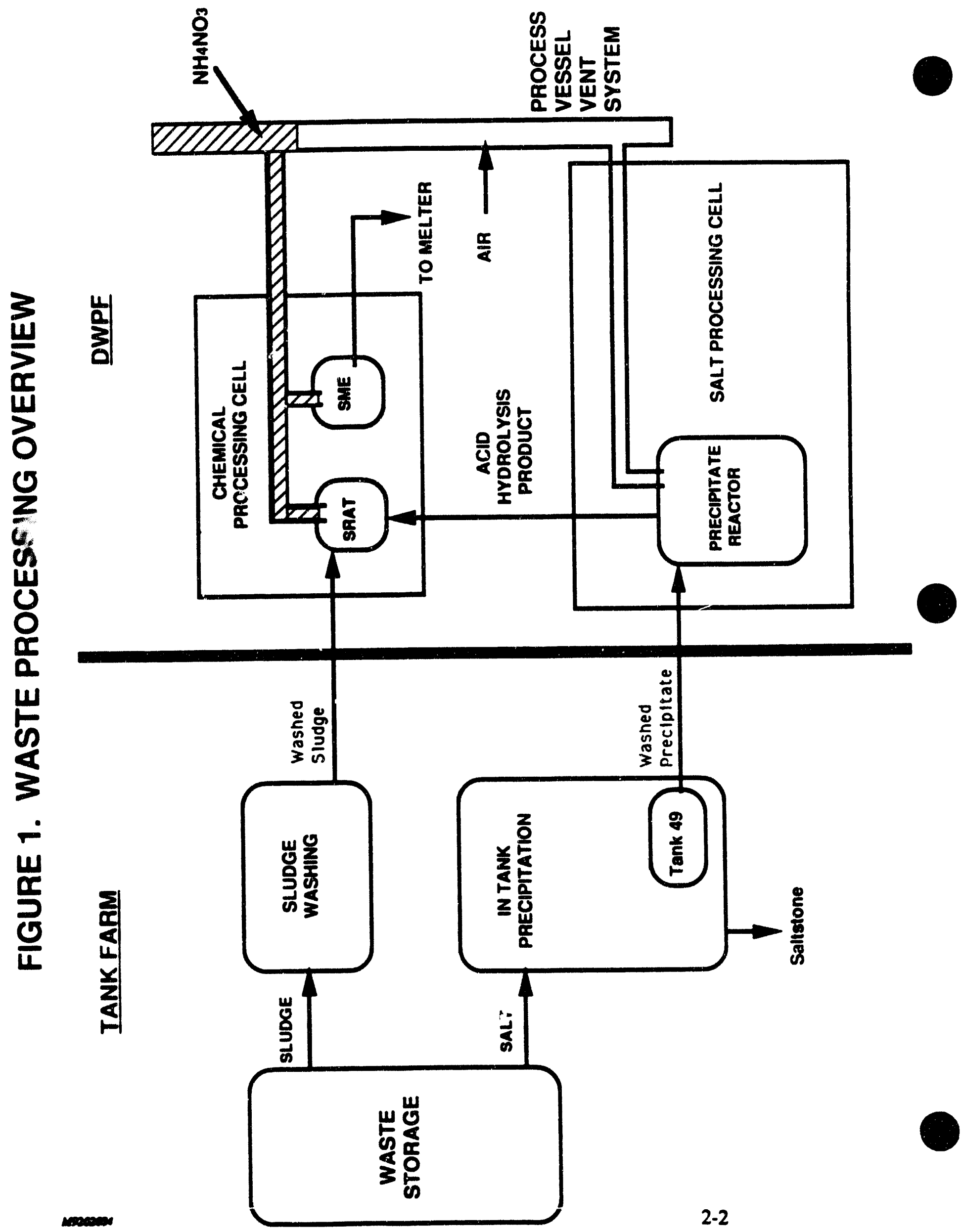




\subsection{TASK FORCE STIJIIES}

The Task Force completed its work on an ambitious schedule (one week) and presented its conclusions and recommendations to N. C. Boyter and R. T. Begley on December 19, 1991. WSRC-TR-92-67 (this report) documents the conclusions and activities of the Task Force. The Task Force recommendations emphasize minimizing technical risk but also consider schedule impact, cost, and attainment impact. Members of the Task Force unanimously agreed that these recommendations are the best path forwand for further development and demonstration with minimal technical risk and with reasonable cost and schedule impact.

The Task Force evaluated 32 potential options for mitigating the impact of nitrite on DWPF. From this initial large set of alternatives, two options for the Chemical Process Cell (CPC) and four options for the Salt Process Cell (SPC) were judged to be of sufficiently high technical certainty that they were further developed and assessed in greater detail.

\subsection{TASK FORCE RECOMMENDATIONS}

\subsubsection{Recommended Options for thi Chemical Process Cell}

It is recommended that both of the options below be pursued for the highest technical certainty of mitigating the accumulation of ammorium nitrate in the CPC by way of any ammonium generated in or transferred to the CPC:

- Scrub ammonia vapors from the CPC vessel vent system and vent the ammonia to the atmosphere through the pump pit recycle tanks.

- Accelerate development of a nitric-acid SRAT process to reduce the quantity of ammonium and hydrogen generated during the melter feed preparation processes.

\section{2.? Recommended Long-Range Options for the Salt Process Cell}

For the highest technical certainty of mitigating ammonium production from the PHA feed to the DWPF, the Task Force recommends installing a corrosion-resistant (Type 304L or Type 316 stainless steel) facility to reduce the nitrite content of washed precipitate feed to $50.01 \mathrm{M}$, and operating the SPC without HAN. The new facility should be designed for maximum flexibility to reduce the nitrite concentration to $\leq 0.01 \mathrm{M}$ by any of the first three technologies listed below: radiolytic nitrite destruction, lare (or final) washing of the stored precipitate, or "Just-In-Time" (JIT) precipitation.

Which of these three technologies is of highest technical certainty is not clear at this time. SRL priorities should be redirected to evaluate the technical uncertainties of these options, as well as the feasibility of a fourth option (also listed below) which would required several engineering changes in the DWPF. In the meantime, a "Workaround" option (Section 3.2.3) should be implemented in order to accomplish the scheduled hot startup of the DWPF in June 1994.

- Recommended Option 1. Allow radiolytic destruction of nitrite by long-term storage of the radioactive precipitate in corrosion-resistant (Type 304L or Type 316) stainiess steel tankage. Allow the nitrite concentration to diminish to less than $0.01 \mathrm{M}$ before transferring the precipitate feed to the SPC. Discontinue adding HAN (no longer needed to eliminate nitrite) during Precipitate Hydrolysis in order to avoid generation of ammonium in the SPC. 
This option would avoid the formation of ammonium nitrate and reduce the amount of organics transferred to the CPC. It was judged to have a technical certainty of about $90 \%$.

- Recommended Option 2. Install a corrosion-resistant (Type 304L or Type 316 stainless steel) late washing facility. If deemed necessary, reprecipitate any dissolved cesium (from radiolytic solubilization of CSTPB during precipitate storage) with more sodium tetraphenylborate. Wash the precipitate to nitrite concentration below $0.01 \mathrm{M}$ before transfer to the DWPF.

Discontinue use IIAN during Procipitate Hydrolysis to eliminate generation of ammonium in the SPC.

This option woild avoid the formation of ammonium ion from HAN and reduce the amount of organics transfierred to the CPC. It was judged to have a technical certainty of about $70 \%$.

- Recommended Option 3. Install a new corrosion resistant (Type 304L or Type 316 stainless steel) facility for "Just-In-T "me" precipitation. Discontinue the use of the sodium nitrite cosrosion inhibitor in the precipitation process. Wash the precipitate to reduce the nitrite and nitrate concentrations below O01M before transfer to the DWPF. Discontinue the use of HAN in Precipitate Hydrolysis to eliminate generation of ammonium in the Salt Process Cell.

"Just-In-Time" precipitation would reduce the storage time before transfer of the material to the DWPF, which would reduce benzene emissions in the Tank Farm and the quantity of organic irradiation products (ionic species and high-boilers) formed during the current two-year average storage time. This option would avoid formation of ammonium nitrate and reduce the amount of organics transferred to the CPC. It was judged to have a technical certainty greater than or equal to that of the current ITP process.

- A fourth option involved several engineering changes in DWPF, retaining the current tank farm operating strategy and use of HAN in the precipitate hydrolysis process. A chemical agent (base) would be added to raise the $\mathrm{pH}$ of the Precipitate Hydrolysis Aqueous product and convert ammonium ion to ammonia. Re-routing the Salt Process Cell vessel vent would allow venting the ammonia out the SPC independently of the CPC vent system. This option was judged to have a technical certainty of about $80 \%$ for mitigating the accumulation of ammonium nitrate in the CPC from the SPC operation, but it would do nothing to mitigate the quantity of organics transferred to the CPC. To address the organics a physical separation of the organic solids (settling followed by decantation) was included in this option. The technical certainty of the organics separation step was deemed to be about $75 \%$, so that the technical certainty of the combined steps is about $60 \%$.

\subsubsection{Recommended Short-Term Workaround Option}

Until a new corrosion-resistant facility can be installed, a "workaround" option is recommended to permit hot startup of the DWPF as scheduled for 6/94.

Workaround Option. Use the existing Type 304L stainless-steel precipitate pump tanks in the Interarea Transfer System (i.e., the Low Point Pump Pit and the Auxiliary Pump Pit) and the Hastelloy (Cabot Corp.) C-276 Precipitate Reactor Feed Tank in the DWPF Salt Process Cell to store the precipitate as long as is necessary for radiolysis to reduce the nitrite concentration to $0.01 \mathrm{M}$ or less in the precipitate feed to the DWPF. Operate the SPC without HAN (no longer necessary). 
This workaround option is judged to have a technical certainty $>90 \%$. It would permit the start of cold chemical runs in the DWPF, using a nonradiaactive precipitate simulant containing a maximum of $0.01 \mathrm{M}$ nitrite, and it would permit hot startup with real waste precipitate by June 1994, on schedule. However, the DWPF would incur a severe attainment penalty until one of the long-term options (Section 3.2.2) comes online.

\subsubsection{Actions Recommended for Immediate Implementation}

The following actions are recommended for aggressive implementation to reduce the technical uncertainty remaining in the radiolysis option:

- Confirm the radiolytic destruction of nitrite by obtaining kinetic data of sufficient quality to design a nitrite radiolysis facility. The experiments should be done with a precipitate slurry containing Cs-137 and with a composition similar to that projected for Tank 49 to make the results applicable to real waste.

- Determine the forecasted Cs-137 concentrations for the existing In-Tank Precipitation schedule to use in sizing the radiolysis tankage.

- Appoint a Task Force to optimize startup attainment using the pump pits and the PRFT to implement either the radiolysis option or the late-washing option.

- Demonstrate the modified DWPF flowsheet at TNX at workaround nitrite levels $(0.01 \mathrm{M})$ and long-term nitrite levels $(0.00$ to $0.01 \mathrm{M})$ with simulated precipitate. In addition, perform benchscale experiments with irradiated precipitate feeds without HAN.

- Provide design basis for CPC vent system ammonia scrubbers.

- Aggressively develop a nitric-acid sludge adjustment flowsheet.

- Determine the amount of any ammonium tetraphenylborate in real precipitate, either as a result of waste content or radiolysis reactions.

- Obtain corrosion data on Type 304L and Type 316 stainless steels in zero-nitrite washed precipitate.

- Obtain corrosion data in Shielded Cells on Type 304L and Type 316 stainless steels in samples of washed precipitate.

\subsubsection{Results from Immediate Actions}

Following the presentation (Appendix $\mathrm{H}$ ) of options to mitigate the impact of nitrite on DWPF to senior SRS management, an aggressive team effort was implemented to assess the technical viability of destroying nitrite by radiolytic reactions. More detailed results will be documented later by the respective investigators. A synopsis of the results is included below.

- The G-value for nitrite destruction was found to be dose-rate-dependent in an unfavorable direction (i.e., the lower the dose rate, the lower the G-value). The G-value expected in the pump pit workaround option is about 0.25 , reducing the attainment for this option to about $2 \%$ and increasing the size of the tankage required for the long-term radiolysis facility by $220 \%$.

- The cesium-137 concentrations in Tank 49 will average about $24 \mathrm{Ci} / g a l$ for the first five years of DWPF/ITP operation, and are forecast to reach levels of as low as $10-12 \mathrm{Ci} / \mathrm{gal}$. 
- Ammonium ion is formed not only by decomposition of excess HAN, but also during imadiation of precipitate slurries that simulate the composition of the material transferred from Tank 48 to Tank 49.

- Radioysis products of the simulated slurries include ionic organic species (highly polar and water soluble), including formate, oxalate, and many as yet unidentified ionic organic species. Precipitate hydrolysis studies have found that copper catalyst activity is reduced when irradiated precipitate slurries are acid-hydrolyzed, requiring additional copper beyond the reference $400 \mathrm{ppm}$ and causing concern about exceeding the solubility of copper in the borosilicate glass product. This concern is heightened by the longer storage times necessitated by diminishing $G$ values (first item above). The reduced catalyst activity is believed to be the result of a complexing mechanism involving the organic ionic species and is an active area of research and development.

- The counterions formed from nitrite destruction include carbonate and hydroxide. This increases the formic acid requirement in the acid hydrolysis process, creating additional concerns about foaming (due to evolution of $\mathrm{CO}_{2}$ ) in the Precipitate Reactor feed step and increased hydrogen generation rates in the CPC from the additional formic acid and formate in the PHA.

Based on these results and concerns, a major effort to assess the Late Washing option was initiated in late February, 1992. The late wash option considered most likely to be achievable by the 6/94 radioactive operation uses the Auxiliary Pump Pit Precipitate Tank as the wash tank. Late washing can address all these concerns by washing out the soluble species (assuming the ammonium in the spent wash is purged from the system before reprecipitating). The main technical uncertainties to be addressed were the crossflow filter performance and the impact of the spent wash on saltstone performance, twn as identified by the Nitrite Task Force. 


\subsection{SCHEDULE AND COST OF RECOMMENDED OPTIONS}

This section summarizes the expected cost and schedule for the various options developed. More detailed schedule breakdowns are provided in Appendix E.

\subsection{SALT PROCESS CELL OPTIONS}

\subsubsection{Radiolysis Facility}

A Nitrite Radiolysis Facility (Section 3.2.2) is estimated to cost about $\$ 35$ to $\$ 50$ million and may take about 5 to 6 years to bring online. The cost estimate is based on a current project estimate of $\$ 54$ million for installing two 750,000 gallon stainless-steel low-level waste tanks in the waste management facilities. The low-level waste tanks do not include cooling coils or an inert-gas blanketing system.

\subsubsection{Late Washing Facility}

A Late or "Final" Washing Facility (Section 3.2.2) is estimated to cost about $\$ 50$ to $\$ 100$ million and will take about 6 to 8 years to bring online. The cost estimate is based on the project estimate of \$54 million for installing two 750,000 gallon stainless-steel low-level waste tanks plus cooling coils, inert gas blanketing, and allowances for adding a new crossflow filter cell, a nitrogen-inerted benzene stripping column, associated filtrate hold tanks, and sampling and analytical capability. These tanks do not include cooling coils or an inert-gas blanketing system.

\subsubsection{Just-in-Time Precipitation}

The cost and schedule for a "Just-in-Time" Precipitation Facility (Section 3.2.2) would be about the same as for a Late Washing Facility. The cost would be reduced significantly if it is possible to tie in to the crossflow filter cell and benzene stripping columns that are part of the ITP facilities.

\subsubsection{Startup Workaround by Pump Pit Radiolysis}

Only minor modifications are anticipated for the precipitate pump tanks to implement pump-pit radiolysis as a startup workaround (Section 3.2.3). The spare penetrations in the Low-Point Pump Pit (or the Auxiliary Pump Pit) would be extended prior to processing radioactive feed, to allow future tie-ins of the new long-term nitrite reduction facility with minimal radiation exposure. This option is estimated to cost about \$1 million and take about 14 months to complete.

\subsubsection{Ammonia Venting and Organics Separation}

The combined chemical and engineered solution (Section 3.2.2, fourth option) to vent ammonia from the SPC is estimated to cost about $\$ 10$ million and will take about 3 years to complete. Re-routing of the SPC vent would conflict with the current DWPF Integrated Cold Run schedule. The cost estimate stated here is an average of individual estimates made by members of the Task Force. 


\subsection{CHEMICAL PROCESS CELL OPTIONS}

\subsubsection{Ammonia Scrubbers}

The CPC options to scrub ammonia (Section 3.2.1) are estimated to cost about \$5 million and would take about 27 months to complete. The switch to a nitric acid flowsheet, if found to be viable, would have minimal cost and schedule impact. The cost estimate stated here is an average of individual estimates made by members of the Task Force. 


\subsection{NITRITE CHEMISTRY IN THE TANK FARM}

In the Tank Farm, nitrite is present in the stored wastes and is aiso formed by radiolytic conversion of nitrate ion in the residual soluble waste. Sodium nitrite will be added to both the washed tetraphenylborate precipitate and the washed sludge waste to inhibit pitting corrosion.

Nitrite is decomposed by radiation when organic compounds (such as the potassium tetraphenylborate[2] precipitate) are present. The loss of nitrite is proportional to the radiation dose and depends on the type and concentration of organic material present, but is independent of the nitrite concentration (i.e., the reaction is zero order in nitrite). Hence, there is a need to replenish the nitrite, and sodium nitrite will be added periodically to the stored washed precipitate in order to maintain the required level of pitting corrosion inhibitor in Tank 49. Additional details on pitting corrosion and inhibitor requirements are contained in Appendix $\mathrm{C}$ and additional details on radiolysis of nitrate and nitrite solutions are contained in Appendix D.

\subsection{NITRITE CHEMISTRY IN THE DWPF}

The washed precipitate will be reacted with formic acid and a copper catalyst in the SPC to convert the potassium tetraphenylborate mainly to benzene. At the same time, nost of the nitrite ion in the washed precipitate will be converted to nitrous acid. Nitrous acid is very reactive and initiates chain reactions that produce organic compounds other than benzene, including tars and high-boilers. High-boilers, such as diphenylamine and biphenyl, are difficult to remove from the PHA. Tars are of such low volatility that they would not be removed from the Precipitate Reactor to any appreciable extent and could drastically foul heat-transfer surfaces within the PR.

To prevent the formation of tars and reduce high-boiler production in the PR, hydroxylamine nitrate (HAN) is added to the reaction. Nitrous acid reacts rapidly with HAN to generate nitrous oxide $\left(\mathrm{N}_{2} \mathrm{O}\right)$, reducing the severity of reactions of nitrous acid with the organics. Although the production of tars and high-boilers could be controlled within acceptable limits for the SPC operation with HAN to destroy the nitrite, a significant quantity of high-boilers would still be present in the aqueous product. These high-boilers probably would be adsorbed on the solid sodium titanate and sludge particles.

\subsection{SOURCES OF AMMONIUM ION}

Ammonium ion can result from at least two and possibly three independent sources, as shown in Figure 2.

- Excess HAN added to destroy nitrite in the Precipitate Reactor (Section 5.2 above) eventually decomposes, yielding ammonium ion in solution. Under the acidic conditions (pH 3 to 4) in the PR, the ammonium ion remains largely dissolved in the PHA stream from the SPC.

- A second source of ammonium ion is the reaction of nitrate and/or nitrite ions in the PHA when it is combined with sludge containing formic acid in the SRAT and SME. If the sludge does not contain noble metals, the resultant slurry remains acidic ( $\mathrm{pH} 4$ to 5.5), and the ammonium ion remains largely in solution and is eventually fed to the glass melter. However, during IDMS runs with sludge containing noble metals, the formic acid was catalytically decomposed to hydrogen and carbon dioxide, increasing the $\mathrm{pH}$ of the slurry (in some cases to neutrality, 
WSRC-TR-92-67

Reviaion 0

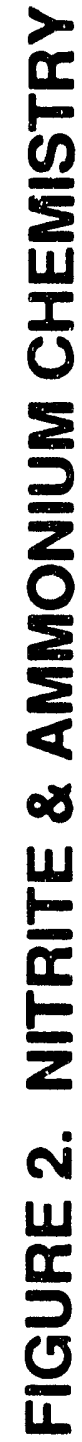

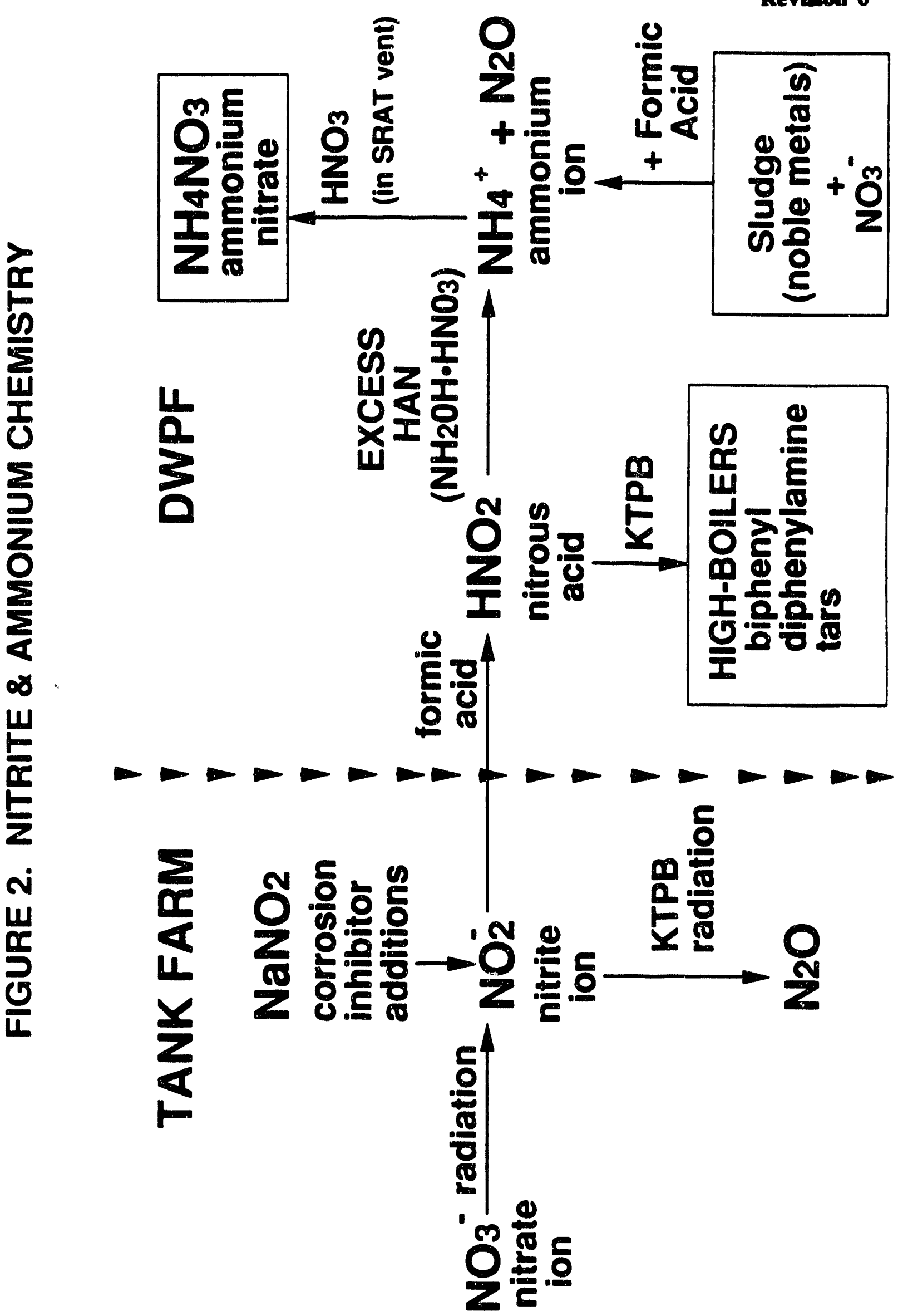


pH 7). The higher pH premoted ammonium ion conversion to dissolved ammonia, which was released to the vessel veat system (Figure 3). Although this source of ammonium ion is smaller than the HAN source, it is estimated to account for about $10 \%$ of the total potential ammonium.

- Some ammonium ion might be present in the stored salt cake used to produce the tetraphenylborate precipitate. Although this source is expected to be small compared to the first two sources, the Task Force agreed that all sources must be addressed to obtain a complete and technically certain solution to the ammonium nitrate problem. 
$\sum_{0}^{\infty}$

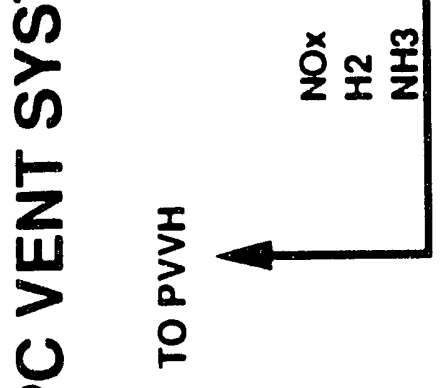

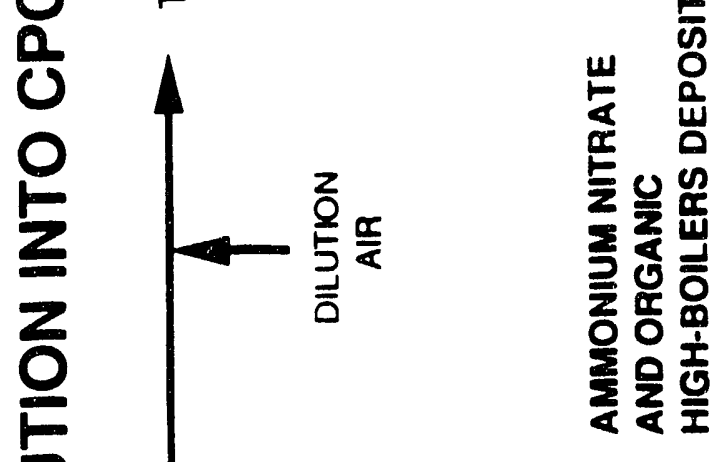

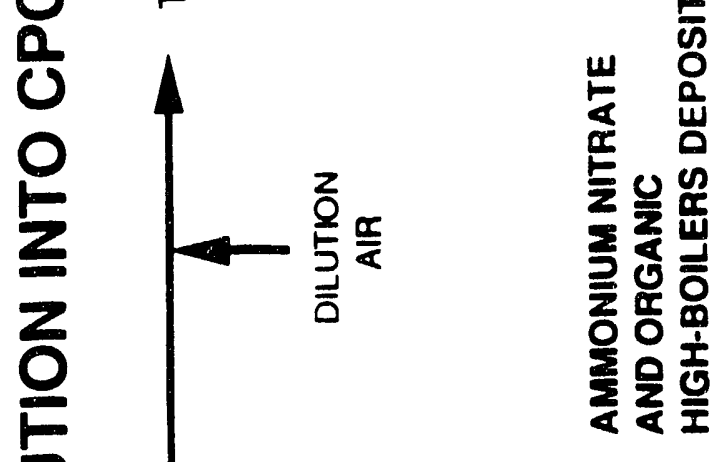

(3)
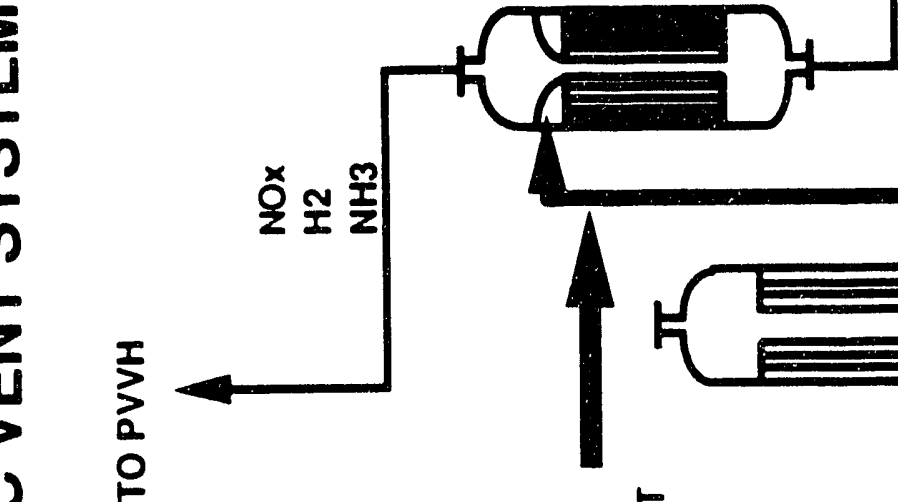

$15 \frac{5}{\frac{\pi}{4}}$

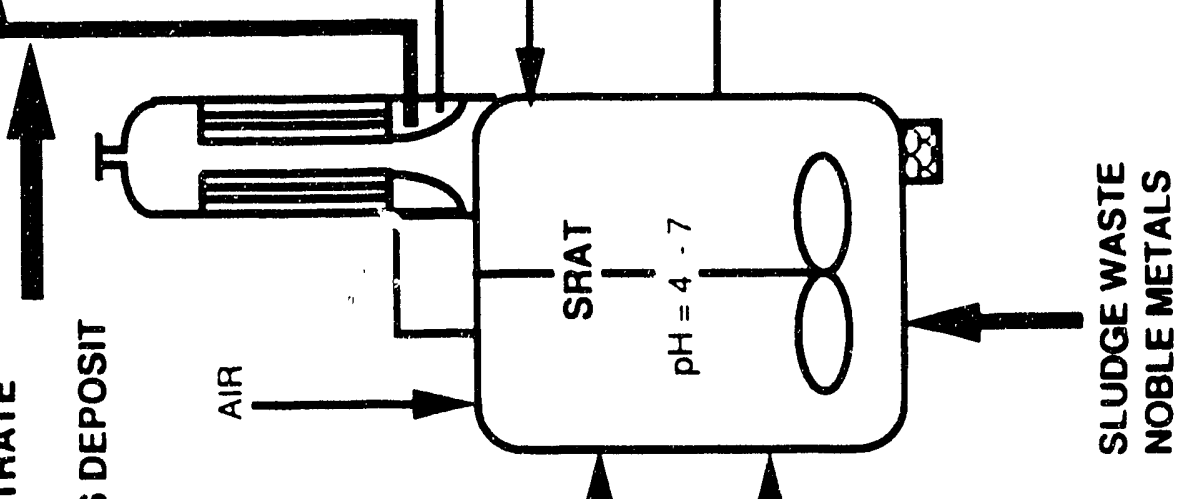

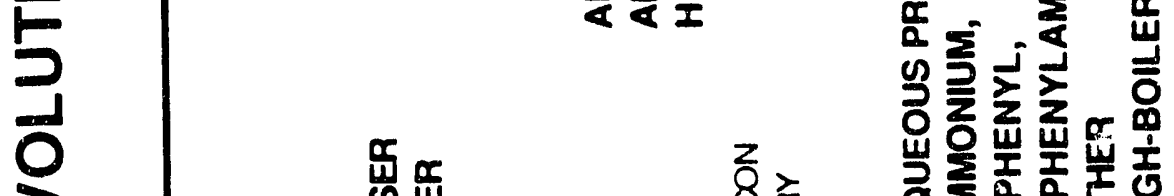

iII

$\sum^{\frac{\pi}{2}}$

๓ं

㟧

骂

$\frac{5}{11}$
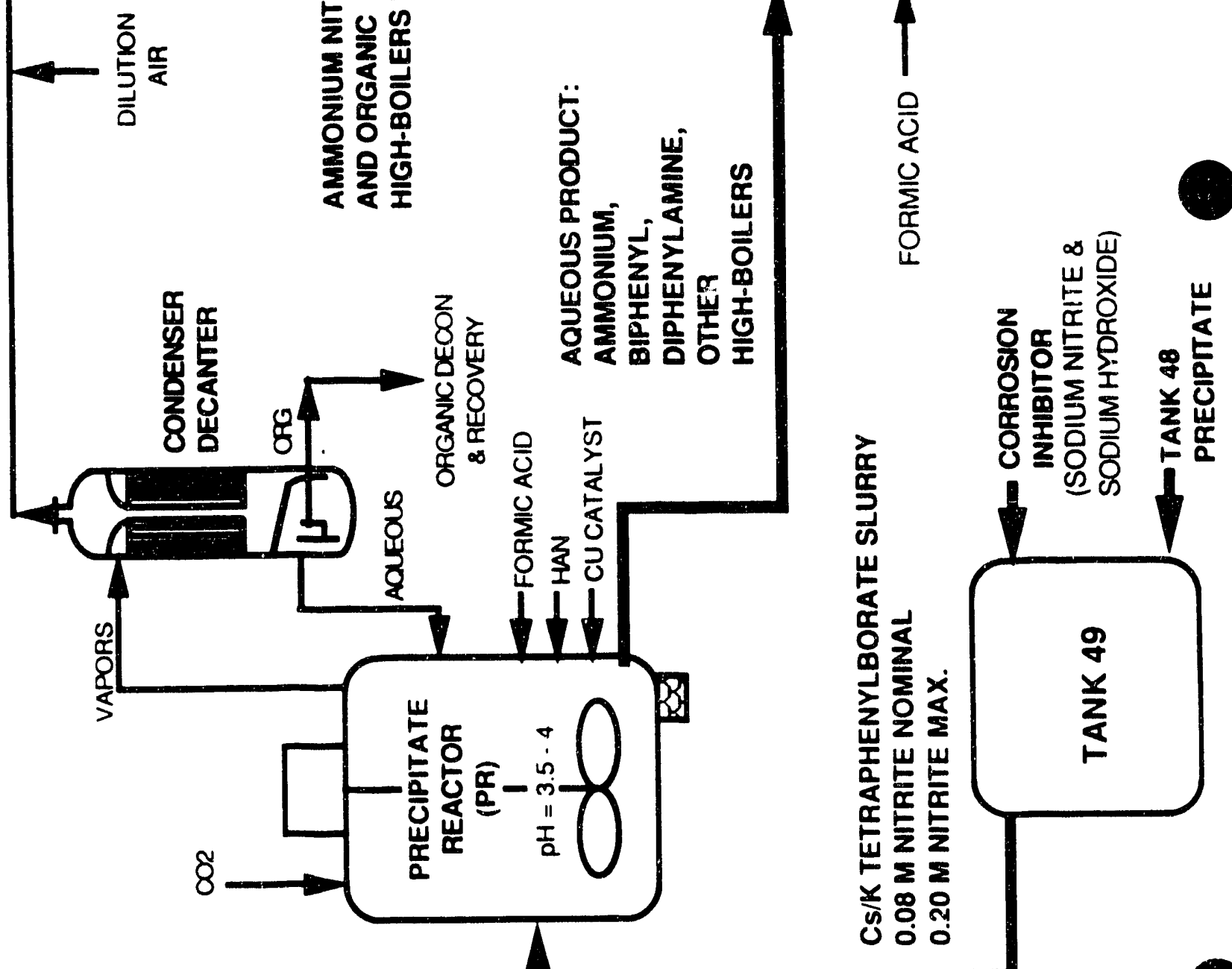


\subsection{DESCRIPTION OF OPTIONS WITH HIGHEST TECHNICAL CERTAINTY}

\subsection{SALT PROCESS CELL: RADIOLYSIS FACILTYY}

\subsubsection{Approach}

Allow radiolysis reactions to cestroy nitrite and reduce the nitrite concentration to less than $0.01 \mathrm{M}$ in the precipitate feed to the DWPF by storing the washed precipitate feed in corrosion resistant (stainless steel) tankage. The facility could be designed with sufficient capacity to eliminate the need for Tank 49 (including the operating costs, sampling requirements, and sodium nitrite inhibitor additions). An overview of the radiolysis option is depicted in Figure 4.

\section{1.\% Process Details}

Size the radiolysis facility to achieve an adequate supply of precipitate feed to DWPF with reasonable control of the nitrite concentration and radioactivity level of the precipitate transferred to the radiolysis facility. Operate the Salt Process Cell without HAN, based on data from scoping experiments that indicate HAN is not required in the SPC for nitrite concentrations $\leq 0.01 \mathrm{M}$.

\subsubsection{Technical Certainty Rating}

The Task Force rated the technical certainty of this option at $>90 \%$.

\subsubsection{Technical Certainties and Benefits}

- No HAN would be needed in SPC, based on scoping experimental data. The annual cost savings from eliminating use of HAN in the DWPF is about $\$ 750,000$.

- Nitrite consumption has been demonstrated in laboratory experiments (irradiation in cobalt-60 facility).

- Would reduce organic carryover as well as eliminate the main source of ammonium nitrate.

- Facility could be sized to free Tank 49 for other uses and avoid continual additions of sodium nitrite inhibitor.

- Would have no impact on In-Tank Precipitation startup schedule.

- Would require no new chemical additions.

\subsubsection{Technical Uncertainties and Risks}

- Low Cs-137 concentrations in waste would increase radiolysis time and might impact DWPF attainment.

- Need to demonstrate precipitate hydrolysis process on irradiated feed without HAN. Earlier demonstrations with HAN showed problems with maintaining copper catalyst activity for phenylboric acid hydrolysis.

- Would not affect ammonium present in precipitate feed or mitigate ammonium generated in the CPC. 


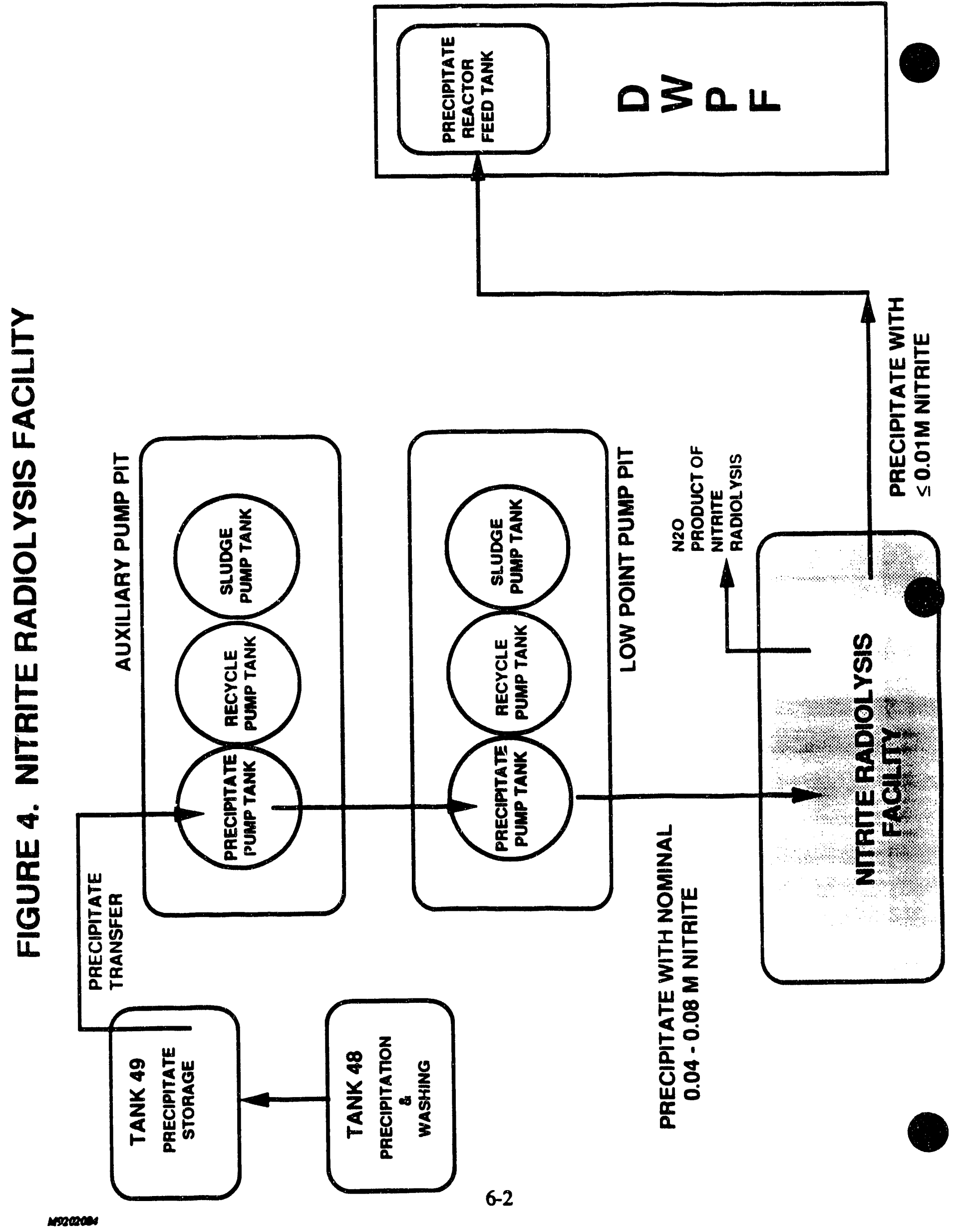


- The nitrite destruction rate may be sensitive to other variables including temperature, dose rate, and organic concentration.

\subsection{LATE (OR FINAL) WASHING}

\subsubsection{Approach}

Remove nitrite by reprecipitating* and rewashing small batches of ITP product in a new corrosion-resistant facility prior to transfer to DWPF (Figure 5). This option both addresses the ammonium nitrate issue and reduces the quantity of organics transferred to the CPC. It has been proposed several times in the past ten years, but the proposals did not include the required benzene stripping and nitrogen purging. The late washing option as presented here would be a new, large facility, but it might be possible to modify a pump pit to implement the wash and meet the 6/94 radioactive operation startup date.

\subsubsection{Process Details}

Current operating plans require storing the ITP washed precipitate in Tank 49 for an average of two years before it is transferred to S-area. During this storage, radiolysis would destroy about $15 \%$ of the tetraphenylborate, solubilizing some of the Cs-137 activity and generating various organic decomposition products. Radiolysis would also consume the nitrite corrosion inhibitor, necessitating its periodic replenishment, which would increase the sodium content of the S-Area feed by about $0.08 \mathrm{M}$ to $0.16 \mathrm{M}$ per year.

A new corrosion-resistant (Type 304L or Type 316 stainless steel) "late-washing" facility would be installed. The solubilized Cs-137 would be reprecipitated with sodium tetraphenylborate, combined with small batches of existing ITP precipitate, and washed in the new facility to reduce the nitrite concentration to less than $0.01 \mathrm{M}$ and remove the added sodium before transfer to the DWPF. Use of HAN in precipitate hydrolysis would be discontinued to eliminate generation of ammonium in the Salt Process Cell.

The "late washing" facility would essentially be a half-size ITP facility, consisting of:

- A source of sodium tetraphenylborate (NaTPB), oxalic acid, nitrogen, etc. (connected to current Cold Feeds, or a stand-alone supply).

- A filter cell (similar size to one of the current ITP filters).

- A nitrogen-blanketed benzene stripper column (similar to the current ITP "small" column).

- Filtrate tanks and analytical capability.

- Two stainless-steel, shielded, double-wall, inert-gas-blanketed tanks for reprecipitation and washing (fulfilling functions similar to those of Tanks 48 and 49).

*The need to reprecipitate soluble Cs- 137 freed by radiolysis of the slurry should be carefully assessed. 
WSRC-TR-92-67

Revision 0

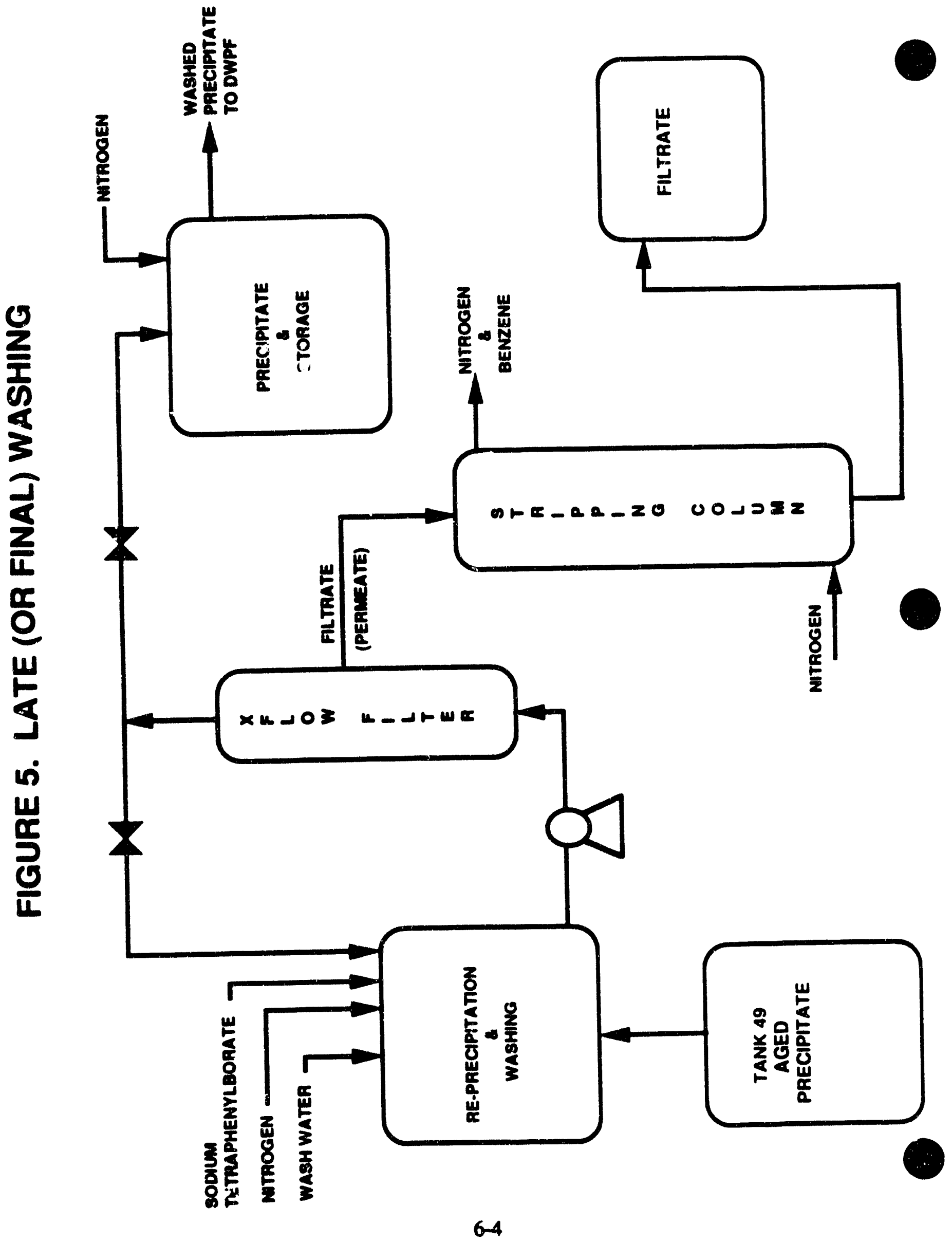


The size of the two tanks would determine the batch size, and thus the number of cycles per year (e.g., approximately one cycle per month at 50,000 gal each). ITP could be operated per current plans, or all/part of the washing could be cleferred to the new facility, or the corrosion inhibitor content of Tank 49 could be increased.

\subsubsection{Technical Certainty Rating}

The Task Force rated the technical certainty of this option at $>70 \%$.

\subsubsection{Technical Certainties and Benefits}

- HAN would not be needed in the SPC, because nitrite would be $<0.01 \mathrm{M}$ in S-Area feed.

- The ammonia and heavy-organics problems in the SPC should be eliminated.

- The required glass production would be reduced, because of the lower sodium content of the S-Area feed.

- Concem about eventually exceeding S-Area's limit of $0.45 \mathrm{M}$ sodium (because of inhibitor additions over an extended time) would be addressed.

- The amount of organic decomposition products in the feed to the SPC (resulting from radiolysis of tetraphenylborate during storage in Tank 49) would be reduced.

- Any concern about corrosion of Tank 49 would be decreased (if additional inhibitors were added for "comfort", or if less washing were done).

- ITP attainment would increase if some of the washing were deferred to the new facility.

- The new facility could partially utilize and/or duplicate the existing ITP design.

- No new chemicals would be required (although the amnunt of chemicals currently used would increase).

\subsubsection{Technical Uncertainties and Risks}

- The organic content (TPB-decomposition products) of the feed to Z Area would increase. The ability to produce acceptable quality saltstone would have to be investigated, demonstrated, and perhaps re-permitted.

- It is known that irradiated feed has a very different rheology (e.g., shear stress, viscosity, "purmpability") than does fresh precipitate. With irradiated feed, the ITP filter process design has been demonstrated only on a very limited basis (e.g., on a very small laboratory scale). Note that this concern is also valid for the current ITP process (see Section 8 , Generic Recommendations).

- The late washing facility may increase ITP workload, and may require additional manpower and incur additional operating expense. The consumption of NaTPB would increase, as would the production of Saltstone (because of the increased volume of washwater) and the amount of benzene generated, which must ultimately be disposed of, possibly in the Consolidated Incineration Facility (CIF). 
- If the Late Wash Facility is operated by ITP, the degree of coupling and the complexity of operations and communications between ITP and S Area may increase, because of the smaller inventory of washed feed available at any given time.

- The late wash would not remove ammonium ion if it were present in the salt waste and precipitated in Tank 48 as ammonium tetraphenylborate.

- The late wash would remove soluble ammonium ion only if the reprecipitation were not used and the ammonium were purged from the spent wash water.

\section{3 "JUST-IN-TIME" PRECIPITATION}

\subsubsection{Approach}

Perform escentially the same precipitation and washing process as planned for ITP in a new corrosion-resistant (stainless steel) facility but reduce the storage time. The precipitation and washing tank (Tank 48 analogue) would have capacity on the order of 0.5 to 1 million gallons, and the storage tank would have capacity of about 75,000 to 150,000 gallons. The facility would deliver feed with $50.01 \mathrm{M}$ nitrite to the DWPF SPC, which would be operated without HAN.

\subsubsection{Process Details}

The storage time of the precipitate would be reduced to about 2 to 5 months by the closecoupling of precipitation in the new facility to the DWPF operation. Tanks 48 and 49 would accept DWPF recycle or other wastes, which alleviates concerns about waste storage capacity during the DWPF startup. About 133,000 gallons of precipitate is to be generated every four months according to current operating plans for ITP. Current plans require storing the ITP washed precipitate in Tank 49 for an average of two years before it will be transferred to $S$ Area. During the two year storage, radiolysis would destroy about $15 \%$ of the tetraphenylborate, solubilizing some of the Cs-137 activity, and generating a variety of organic decomposition products, including benzene, high-boilers, and ionic species (formate, oxalate, and other unidentified ions).

Radiolysis would also consume the nitrite corrosion inhibitor, necessitating periodic replenishment with sodium nitrite and increasing the sodium content of the $S$ Area feed by about 0.08 to 0.16 molar/year.

\subsubsection{Technical Certainty Rating}

The Task Force rated the technical certainty of this option as equal to or greater than that for the current ITP process.

\subsubsection{Technical Certainties and Benefits}

- Impact of irradiation on precipitate processing would be mitigated by the reduced storage time, because the amount of organic radiolysis products in the feed to the SPC would be reduced.

- No corrosion inhibitor would be required.

- The SPC ammonia and heavy-organics problems would be eliminated, and HAN would not be needed (because the S-Area feed would be $<0.01 \mathrm{M}$ nitrite).

- Concem about eventually exceeding S-Area's limit of $0.45 \mathrm{M}$ sodiun. (due to inhibitor replenishment over an extended time) would be relieved. 
- Required glass production would be reduced (due to the reduced sodium content of the S Area feed).

- Benzene emissions from the Tank Farm would be reduced by shorter storage times.

- No new chemicals would be required.

\subsubsection{Technical Uncertainties and Risks}

- If the new stainless steel tanks are operated by ITP, the degree of coupling, and the complexity of operation/communications between ITP and S Area, would increase (due to the smaller inventory of washed feed available). This would be an important consideration for the startup period of DWPF and Tank Farm processing, but the schedule for implementation of this option is well beyond the 6/94 DWPF radioactive startup date.

\subsection{CHEMICAL PROCESS CELL: AMMONIA SCRUBßERS}

\subsubsection{Approach}

Design and install scrubbers on the Formic Acid Vent Condenser (FAVC) exit and the Recycle Collection Tank (RCT) vent to prevent any ammonia from reaching the Process Vessel Vent Header. Analyze for ammonia in the SRAT/SME off-gas using, if possible, the planned sample lines and analyzers for hydrogen. Modify the Process Vessel Vent Filter (PVVF) to allow water flooding and soaking for periodic removal of ammonium nitrate. A schematic overview of this option is shown in Figure 6.

\subsubsection{Process Details}

The scrubbed ammonia would be retained in the recycle waste liquid by operating the scrubber during the RCT neutralization. The ammonia would then be vented through the pump pit recycle tank vessel vents. Inspection and cleaning of the jumpers from the SRAT and SME to the FAVC and from the FAVC to the PVVH could be performed periodically. The scrubber water flow requirements are estimated to be small. However, there would be an attainment penalty associated with increased water load to the RCT, which is already an attainment bottleneck. The magnitude of the penalty needs to be assessed after the scrubber design is finalized, and the frequency and duration of scrubber operation are better defined. A potential workaround to avoid the penalty is to use the SMECT contents as the source of the RCT scrubber liquid. See also Section 8.7.

\subsubsection{Technical Certainty Rating}

The Task Force rated the technical certainty of this option at $>75 \%$.

\subsubsection{Technical Certainties and Benefits}

- Water is effective for scrubbing ammonia gas.

- Have F \& H Canyon experience with using scrubber jumpers.

- Have ability to remove, inspect, clean SRAT, SME, and FAVC jumpers and the PVVF. 


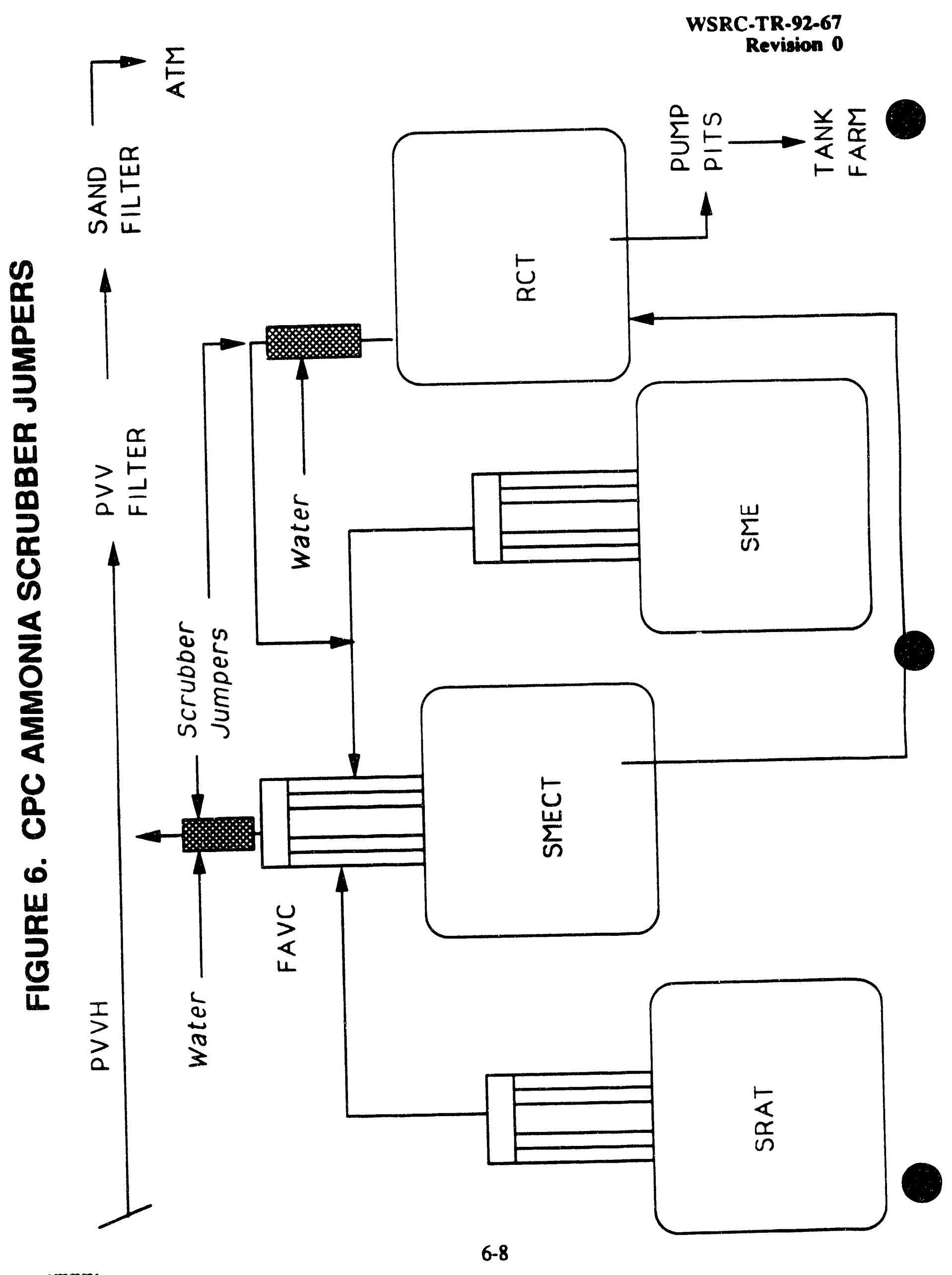




\subsubsection{Technical Uncertainties and Risks}

- Scrubber efficiencies are never $100 \%$ (but efficiencies in excess of $99 \%$ are readily achievable). See also Section 8.3.

- Possible environmental impact of ammonia release at pump pit.

- SME Condensate Tank (SMECT) equivalent in IDMS has been recently observed to operate alkaline, thereby releasing ammonia.

- Additional aqueous recycle would be sent to tank farm.

- Scrubber liquid would be routed through the RCT, which is expected to be a very busy vessel and a potential attainment bottleneck.

\subsection{WORKAROUND OPTION FOR STARTUP: PUMP PIT RADIOLYSIS}

\subsubsection{Approach}

Use the existing Type 304L stainless-steel precipitate pump pit tanks and the Precipitate Reactor Feed Tank (see Figure 7) for radiolytic nitrite removal to meet the 6/94 radioactive startup date, albeit with a severe attainment penalty until the radiolysis facility (or other long-term solution) comes on line.

\subsubsection{Process Details}

The precipitate feed to the DWPF would be stored in the two Type 304L stainless-steel precipitate pump pit tanks in the Interarea Transfer System (Auxiliary Pump Pit and Low Point Pump Pit) and in the Hastelloy (Cabot Corp.) C-276 Precipitate Reactor Feed Tank (PRFT) in the Salt Process Cell for the time required for radiolysis to reduce the nitrite concentration to $\leq$ $0.01 \mathrm{M}$ in the precipitate feed to DWPF. The DWPF Salt Process Cell would be operated without HAN. Start DWPF Cold Chemical Runs on schedule with precipitate simulant containing a maximum of $0.01 \mathrm{M}$ nitrite.

\subsubsection{Technical Certainty Rating}

The Task Force rated the technical certainty of this option at $>90 \%$.

\subsubsection{Technical Certainties and Benefits}

- No HAN would be needed in SPC, based on scoping experimental data. The annual cost savings from eliminating use of HAN in the DWPF is about $\$ 750,000$.

- Essentially the same as the long-term option with high tochnical certainty for destroying nitrite.

- Nitrite consumption has been demonstrated in laboratory experiments (irradiation in cobalt-60 facility).

- Would reduce organic carryover as well as eliminate the main source of ammonium nitrate.

- Would have no impact on In-Tank Precipitation startup schedule. 


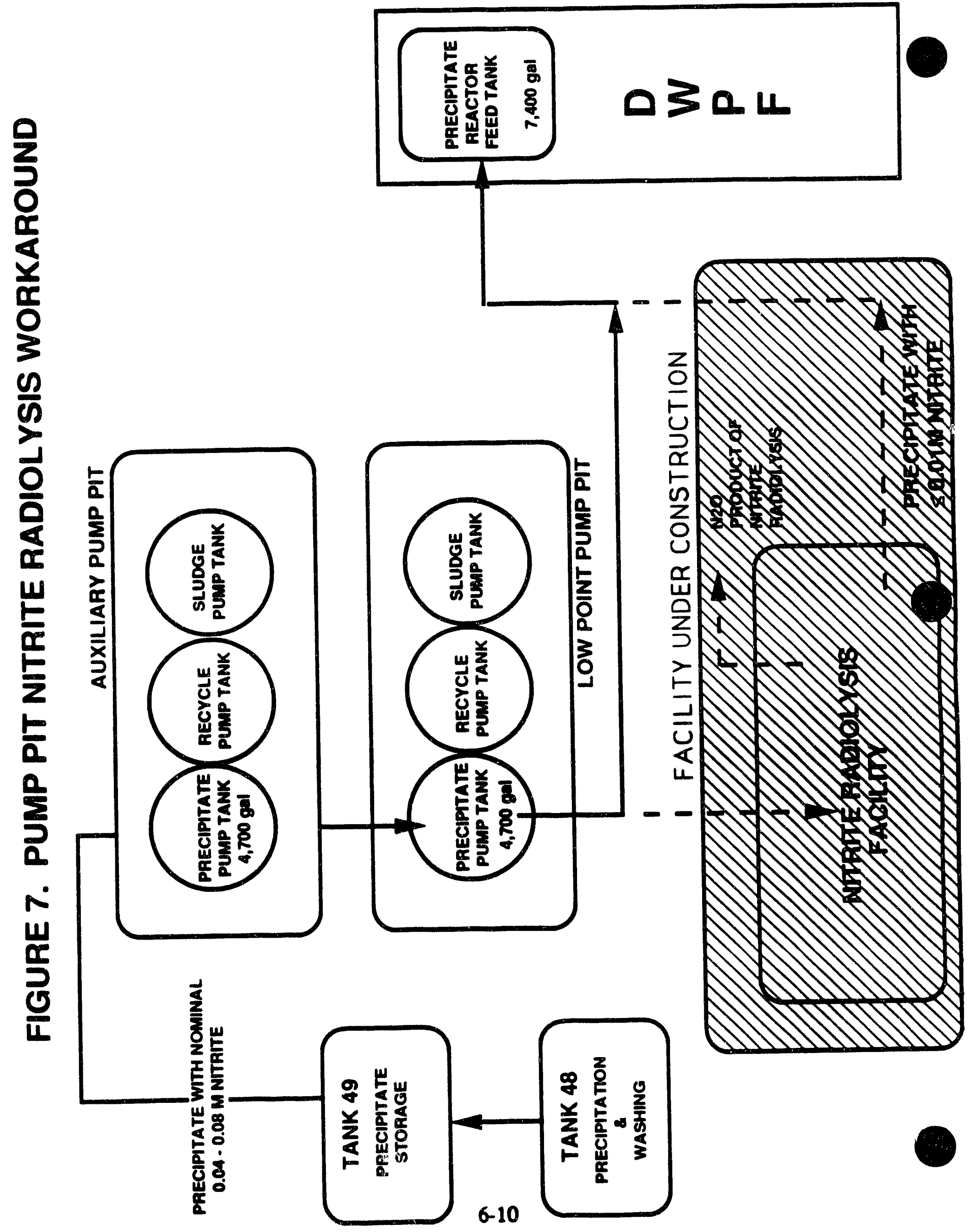


- Would require no new chemical additions.

\subsubsection{Technical Uncertainties and Risks}

- Low Cs-137 concentrations in waste would increase radiolysis time and might further impact DWPF startup attainment.

- Need to demonstrate precipitate hydrolysis process on irradiated feed without HAN. Earlier demonstrations with HAN showed problems with maintaining copper catalyst activity for phenylboric acid hydrolysis.

- Would not affect ammonium present in precipitate feed or mitigate ammonium generated in the CPC.

- The nitrite destruction rate may be sensitive to other variables including temperature, dose rate, and organic concentration.

- The Interarea Transfer Line is made of Type 304L stainless-steel (primary containment) and carbon steel (secondary containment). The adequacy of the carbon-steel secondary containment for transferring uninhibited precipitate feed needs to be assessed.

Note: this concern is also valid for any extended downtime in the current operating scheme. 


\subsection{DESCRIPTION OF OTHER OPTIONS FOR SALT PROCESS CELL}

This section describes other options developed for the SPC to mitigate the ammonium nitrate and organics problems. These options were deemed to have technical certainties $>50 \%$ but not as high as for the radiolysis option.

\subsection{SPC MODIFICATIONS TO MITIGATE AMMONIUM NITRATE BY AMMONIA VENT}

\subsubsection{Approach}

The current Tank Farm operating strategy and the hydroxylamine nitrate flowsheet for the Salt Process Cell is retained to mitigate nitrite. A combined chemical and engineered solution is used to deal with the ammonium formed from the HAN in the SPC, before transfer of the Precipitate Hydrolysis Aqueous (PHA) product to the PRBT. The SPC vent, which presently exits the Salt Cell Vent Condenser (SCVC) and flows into the Process Vessel Vent Header (PVVH), would be separated from the PVVH and routed to a new exhaust location (Figure 8). The Precipitate Reactor (PR) contents would be neutralized after the normal batch cycle, thereby releasing ammonia gas out the new exhaust vent. Since the ammonia coming off the Salt Cell would not contact nitric acid $\left(\mathrm{HNO}_{3}\right.$ ) fumes in the Chemical Process Cell (CPC) or PVVH, no ammonium nitrate would be formed from the SPC HAN source.

Because this approach does nothing to address the heavy organics carried into the CPC with the PHA product, a separate option was devised to work in conjunction with the SPC vent reroute. The organic solids in the PHA would be physically separated from the aqueous by settling and decantation. The organic separation option is discussed in Section 7.2, after the combined engineering and chemical option (below).

\subsubsection{Process Details}

HAN is presently used in the SPC (in conjunction with formic acid) to facilitate curversion of the nitrite ion to nitrous oxide $\left(\mathrm{N}_{2} \mathrm{O}\right)$. This reaction is necessary to avoid, or at least minimize, a competing reaction in which the nitrite reacts in the presence of tetraphenylborate to form organic tars and high boilers. The high boilers can create tarlike compounds that cause fouling and pluggage problems in both the SPC and the CPC. HAN was chosen over other chemical candidates, and its nitrite destruction effectiveness has been proven in the Precipitate Hydrolysis Experimental Facility (PHEF) at TNX.

The SPC vent can be rerouted by utilizing existing spare lines that pass through the 221-S canyon wall and extend underground approximately 50 feet west of the building, where they are capped. These spare lines were initially installed for feeding the PR directly from the Low Point Pump Pit (no longer required with change to an in-canyon Precipitate Reactor Feed Tank). A new facility would be required to provide the motive force and filtration for this new vent. The facility would consist of a concrete structure, blower(s), filter(s), a new stack, and perhaps tie-ins for future benzene-abatement equipment. If direct release of the ammonia to the atmosphere proved unacceptable, then a catalytic converter could be added, which might then allow the vent to exhaust straight into the Zone 1 air tunnel, thereby eliminating the need for a new stack. An additional incanyon HEPA filter would probably be added upstream of the new facility to allow easier access to and changeout of the new blower and filters, with minimal personnel exposure. 
WSRC-TR-92-67

Revieion 0

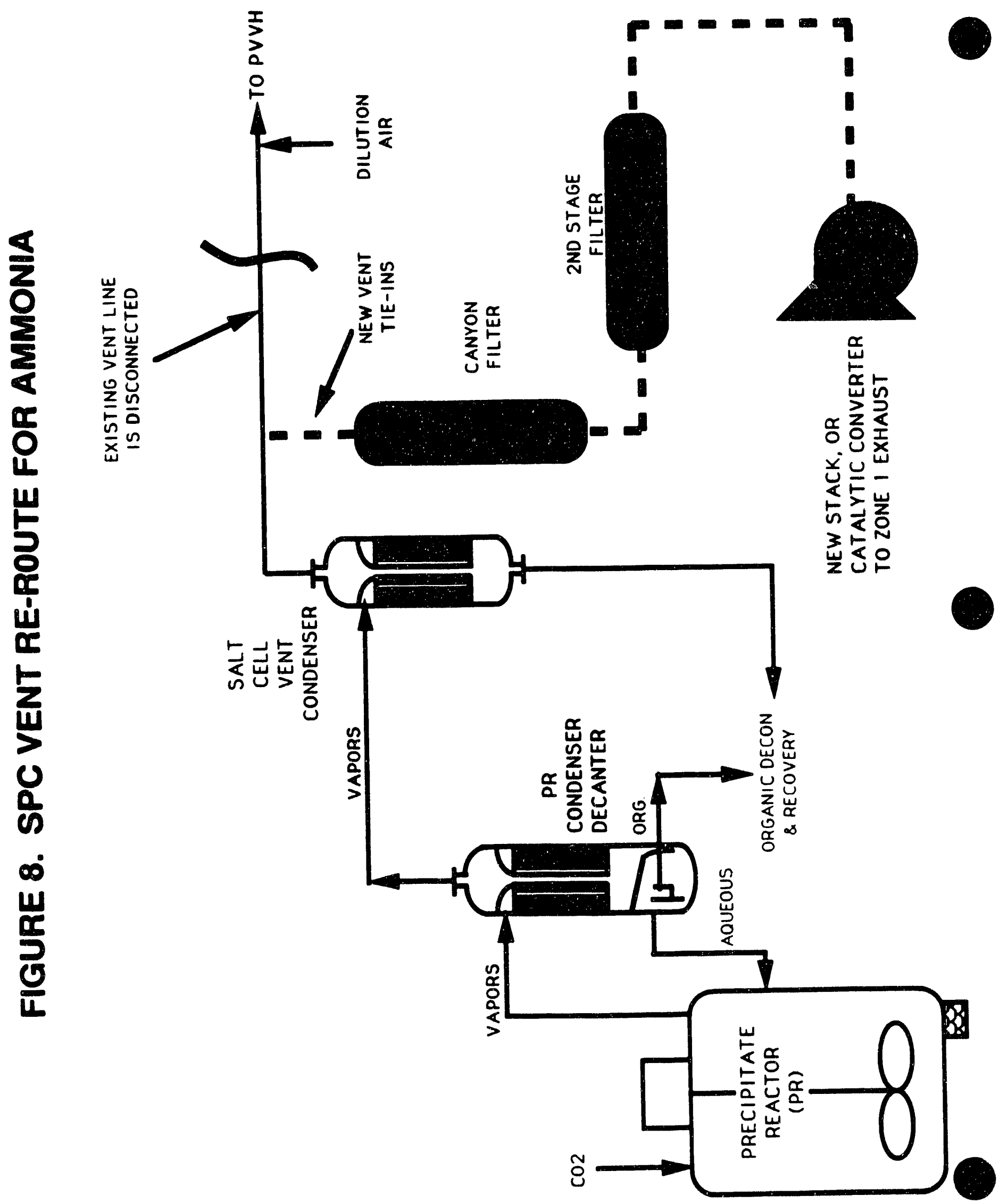


Under the present operating strategy, the PR is maintained acidic (pH 3 to 4) and the ammonium ion remains in the PHA that is transferred to the CPC. To liberate the ammonia from the PR, the $\mathrm{pH}$ of the PR contents would be raised by adding a base, probably lithium hydroxide ( $\mathrm{LiOH}$ ). Lithium has a lesser adverse effect on the glass (susceptibility to leaching) than does sodium or potassium. This adverse effect can be countered by increasing the amount of frit added to the glass, but this reduces the waste loading. The amount of $\mathrm{LiOH}$ required would have to be evaluated. There is also potential that lithium already present in the clean frit could be reduced or eliminated to minimize the added glass volume.

\subsubsection{Technical Certainty Rating}

The Task Forae rated the technical certainty of this option at $>80 \%$ for mitigating the accumulation of ammonium nitrate. However, this option does nothing to reduce the amount of organics transferred to the CPC; that problem is addressed by the physical separation of organics (Section 7.2). If these two options are used together, the combined technical certainty diminishes to $>60 \%$ (Section 7.2.3).

\subsubsection{Technical Certainties and Benefits}

- Two spare lines are available to provide the path out of the canyon for the vent reroute.

- The Salt Cell vent reroute design has already been conceptualized for the benzene abatement proposal.

- The chemical liberation of ammonia gas by neutralization of the PHA has been demonstrated in the laboratory. Essentially all the ammonium ion can be released as ammonia, given enough time and an adequate increase in $\mathrm{pH}$.

\subsubsection{Technical Uncertainties and Risks}

- The primary uncertainty would be the impact, if any, of the ammonia release on the environment and on obtaining an operating permit.

- Effectiveness of a catalytic converter, if required, is unproven.

- Additional glass production and operating costs because of the reduced waste loading from use of an alkali base to raise the $\mathrm{pH}$.

- Potential impact on attainment from increasing the PR cycle to vent the ammonia.

- Initial consideration of exhausting the rerouted vent (no catalytic converter) into the Zone 1 air tunnel was rejected due to concem of ammonium nitrate accumulation in the Sand Filter.

Hence a separate stack is required if a catalytic converter is not used.

\subsection{PHYSICAL SEPARATION OF ORGANIC-COATED SOLIDS}

\subsubsection{Approach}

Many of the options (e.g., see Section 7.1) mitigate accumulation of ammonium nitrate but not the transfer of organic high-boilers to the CPC. A separate option was therefore devised to reduce the quantity of high-boilers when used in conjunction with any of the other options. The organic- 
coated solids in the PHA would be physically separated from the aqueous by settling and decantation. Known solids in the PHA include sodium titanate (or titanium dioxide after the PR processing), traces of sludge solids originally entrained in the salt/sludge separation in the Tank Farm, and solidified high-boilers, which may or may not be coated on the sludge and titanate. The solids would be routed to SME after the vessel is cooled and then transferred to the Melter Feed Tank (MFT) and the DWPF melter (Figure 9).

\subsubsection{Process Details}

After transferring two batches of PHA to the PRBT, the material would be sampled for process control analyses; then the agitator would be turned off and the solids allowed to settle. The aqueous phase would be transferred to the SRAT, as in the current operating scheme. The SME contents would be concentrated somewhat more than currently planned and after SME cool-down, the solids would be re-suspended in the PRBT and transferred to the SME. This should reduce the quantity of high-boilers stripped up into the CPC vessel vent system.

\subsubsection{Technical Certainty Rating}

The Task Force rated the technical certainty of this option at about $75 \%$. When this option is used, together with the option discussed in Section 7.1, the overall technical certainty is about $60 \%$ (cf. Section 7.1.3).

\subsubsection{Technical Certainties and Benents}

- A reduction in the quantity of organic high-boilers transferred into the boiling SRAT vessel.

\subsubsection{Technical Uncertainties and Risks}

- The reduction may not be sufficient to significantly increase attainment.

- Would not mitigate ammonium nitrate problem - must be paired with other option(s).

- Impact on cycle time not determined.

- Settling time for expected range of solids concentrations not determined. 
WSRC-TR-92-67

Revision 0

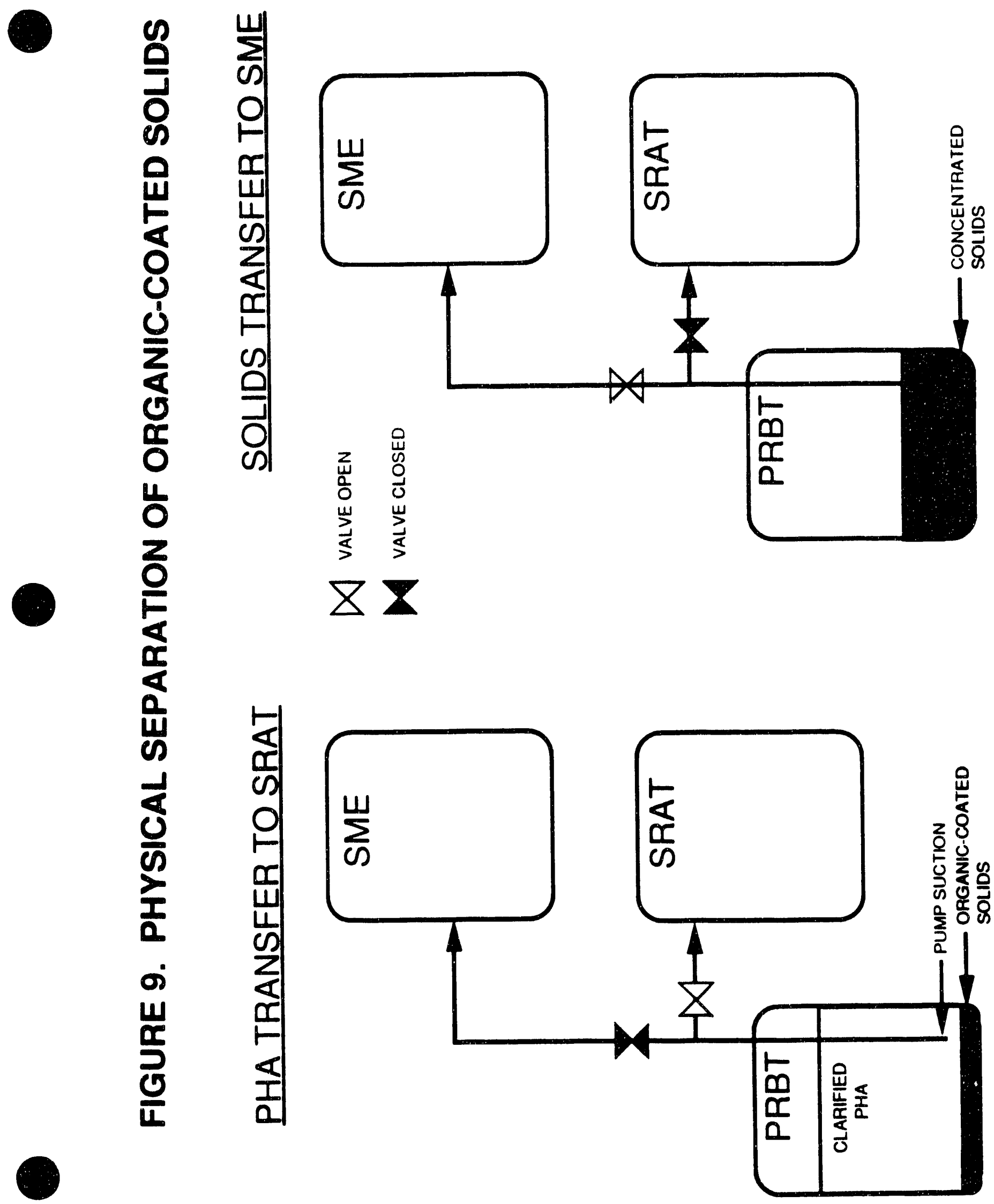




\subsection{GENERIC RECOMMENDATIONS}

This section presents recommendations that are common to many or all of the options considered by the Task Force.

\subsection{REDUCING NITRITE IN THE PRECIPITATE}

For a number of the options examined by tive Task Force, it is desirable to reduce the nitrite concentration in the washed precipitate sent from the Tank Farm to the DWPF. In the option identified for startup (radiolytic reduction of nitrite in stainless-steel pump pit tanks and the PRFT), reducing the nitrite during the workaround period increases the rate at which precipitate can be fed to the DWPF. Increasing this rate is desirable for two reasons:

- Salt space in the Tank Farm is currently tight. Increasing the precipitate feed rate would increase the rate at which salt can be removed from the Tank Farm. Expeditious rates of salt removal are needed to meet regulatory and DOE requirements, and to ensure that sufficient space is available in the Tank Farms to receive new wastes (including DWPF recycle and Extended Sludge Processing wash water).

- Operating the DWPF at low rates would be economically unattractive because much of the operating costs are fixed.

With respect to reducing the nitrite in the Tank Farm, the Task Force makes the following recommendations:

- Additional washing in Tank 48 should be pursued to reduce the concentration of aggressive corrosion species, such as nitrate, and hence reduce the required level of nitrite corrosion inhibitor. The level of nitrite corrosion inhibitor could be lowered while retaining current safety margins. The additional washing could involve certain penalties, such as reduced ITP rate, increased Saltstone feed, and more frequent nitrite additions to Tank 49. The Task Force recommends that the SRL Corrosion Working group, chaired by D. T. Hobbs, determine the cost and feasibility of additional washing to various nitrite leveis.

- Cooling of Tank 49 with chillers should be pursued since lower temperatures reduce the required level of nitrite. Chiller systems need to be designed with redundancy and other measures to ensure their reliability, since they will be needed to maintain the integrity of Tank 49.

- The monitoring of Tank 49 nitrite levels should be upgraded by improving sampling techniques, analytical capability, and adjustment of nitrite addition frequency. Sampling and nitrite additions are needed more frequently at low nitrite levels, since the rate of nitrite disappearance is fixed.

- Improved inspection techniques for detecting corrosion should considered for Tank 49 because the tank will be operated at inhibitor levels lower than other tanks in the Tank Farm. 


\subsection{REWORXING THE PRECIPITATE}

A plen needs to be developed for reworking procipitate in Tank 49 that cannot be processed through the DWPF. P1 as are to store washed precipitate in Tank 49 for an average residence time of about two years before transfer to DWPF. Such precipitare might become unacceptable to DWPF if:

- An unanticipared DWPF downtime required storing precipitate for longer than two years (because periodic inhibiwor additions during this time would raise the sodium level unacceptably or might produce an unscceptable amount of organic radiolysis products).

- An inadvertent inhibitor addition to Tank $490 \mathrm{or}$ a problem in ITP caused salts to be added to Tank 49.

A limited amount of unpublished bench-scale data exists for filtration of two-year-aged, washed precipitate. 'in data, developed by D. D. Walker, suggest that aged precipitate will filter at an adequate rate. These data need to be published and/or supplemented with further experiments.

The following items also need to be addressed:

- Can Saltstone handle the degraded organics produced ciuring two or more years of aging?

- What are the logistics of transferring a million-gallon batcl. of precipitate from Tank 48 to Tank 49 and washing it? Could the precipitate be washed in Tank 49 similarly to sludge, i.e., by letting the precipitate settle, decanting, adding water, and agitating?

- Related to the two items above, the flexibility of transfers and processing in Tanks 48 and 49 should be evaluated.

\subsection{MTTIGATION OF AMMONIUM NITRATE ACCUMULATION}

Because it is unlikely that any of the options will completely eliminate all ammonium nitrate, and scrubber efficiencies approach but cannot achieve 100\%, the following measures should be adopted:

- Inspect the Process Vessel Vent System routinely. Periodically remove vent jumpers, inspect for ammonium nitrate deposits, and flush if necessary.

- Develop capability to flood the Process Vessel Vent Filter (PVVF) if deposits of ammonium nitrate are found in the vent system.

- To inspect for ammonium nitrate accumulations downstream from the ammonia scrubbers, install inspection ports in the Process Vessel Vent Header similar to those installed in new plutonium vent systems.

- Analyze the gas stream for ammonia (perhaps using the sample lines and anaiyzers that are being installed for hydrogen monitoring). The most critical sample points for monitoring the potential accumulation of ammonium nitrate in the PVVH are regions downstream from the scrubbers. 
- One other concern is that ammonium nitrate could accumulate in the DWPF sand filter, perhaps causing an accident that is not anticipated in the current Safety Analysis Report (SAR). Since the ammonium nitrate hazard cannot be completely eliminated, this should be addressed in the DWPF SAR and the DWPF Operating Safety Requirements.

\subsection{NOBLE METAL TESTING}

The inclusion of noble metals in uxe IDMS sludge feed simulant led directly to identification of several major technical issues for DWPF operation in advance of DWPF Integrated Cold Runs. The Task Force recommends that flowsheet levels of noble metals be included during a portion of the DWPF cold runs, perhaps by including noble metals as part of the waste simulant used for "mercury runs." The noble metals should be tested to demonstrate the ability of the DWPF to control the hydrogen and ammonium nitrate hazards before the facility processes actual high-level radioactive waste.

\subsection{ORGANIC HIGH-BOILER CARRYOVER IN THE SALT PROCESS CELL}

The option to physically separate the organic-coated solids from the aqueous material ransferred to the SRAT may be viable with any of the other options developed. It should be pursued as a contingency option to provide additional mitigation of organic high-boiler carryover.

\subsection{IMPROVING ATTAINMENT DURING PUMP PIT WORKAROUND}

During a radiolysis "pump pit workaround" period, the precipitate feed rate will be limited by the storage time required to destroy nitrite by radiolysis. The Task Force has recommended a number of options that might allow increased precipitate feed rate, including (1) additional washing, (2) cooling of Tank 49, and (3) improved monitoring of nitrite levels in Tank 49.

The Task Force generated a number of other ideas to improve the workaround attainment but didn't include them in the final recommendations because they are not fully developed. However, for the beneht of future groups trying to optimize the workaround rate, these ideas are listed below:

- Radiation sources could be added to one or more of the Interarea Transfer System pump-pit tanks to increase the radiation dose rate. Some possible radiation sources are Cs-137 capsules at Hanford and the cobalt wbes stored in the SRS reactor areas. A good way to use these sources would be to construct a large metal tube in a pump tank, similar to a thermowell, into which the source would be inserted, so that the exterior of the source would remain uncontaminated. The design would include a mechanism for withdrawing the source from the pump tank into a shielded cask for maintenance work in the pump pit.

- An X-ray machine could be used to increase the dose rate instead of a radioactive source. Some specialty plastics are commercially cross-linked using X-ray machines at doses of up to about 8 megarads.

- The purmp pit tanks could be enlarged, perhaps by making them square so that they would fill more of the pump pit.

- A soluble organic might increase the rate of nitrite destruction - for example, ethylene glycol (see Appendix D). The challenge is to find an organic that works at low enough concentration to avoid causing other problems in DWPF.

- One of the recycle pump pits could be converted to precipitate service. 
- One of the tanks planned for the Hazardous Low-Level Waste Processing Tank project could be converted to high-level waste service. By making use of the existing project, it might be possible to accelerate the construction relative to a completely new tank project.

- The solids losding of precipitate in the Tank Farm could be increased, perhaps by settling in Tank 49 and decanting. This would increase the amount of potassium tetraphenylborate precipitate carried along with each pound of nitrite, effectively increasing the attainment of the entire process.

- The feed from the Tank Farm to the DWPF could be diluted in the Precipitate Reactor Feed Tank to reduce the nitrite concentration to $0.01 \mathrm{M}$ or less. This would allow feed from the Tank Farm to be received at the DWPF with nitrite concentrations in excess of $0.01 \mathrm{M}$. This scheme would reduce the storage time required for nitrite radiolysis in the pump pit."

\subsection{DWPF RECYCLE TO TANK FARM}

If implemented, the use of ammonia scrubbers in the CPC vessel vent system might increase the recycle stream flow back to the tank farm.

The adequacy of the Tank Farm to accommodate the DWPF recycle stream should be assessed as soon as the impact of the scrubbers on the recycle flow is defined. Consideration should be given to the needs and benefits of installing an evaporator for the DWPF recycle stream.

- For instance, if it were planned to dilute the feed in the PRFT by a factor of two, the DWPF could accept feed that had been stored only long enough to reduce the nitrite content to $0.02 \mathrm{M}$ or less, rather than $10 \leq 0.01 \mathrm{M}$. 


\subsection{SUMMARY OF ALL OPTIONS CONSIDERED}

\subsection{PROMISING OPTIONS}

\subsubsection{Options That Eliminate Ammonium Formation in the SPC}

OPTION 1: let radiolysis reduce nitrite to $<0.01 \mathrm{M}$ during storage in stainless-steel vessels.

OPTION 2: remove nitrite in late washing facility (see also Options 4 \& 5).

Both of the above were further developed because use of HAN would be eliminated and both address the organics problem.

\subsubsection{Option That Deals with Ammonium Formed in the SPC}

OPTION 3: neutralize (raise $\mathrm{pH}$ ) of PR contents to evolve ammonia, and re-route SPC vent.

This option was selected for further development and supplemented with physical separation of the organic-coated solids to address the organics issue.

\subsubsection{SPC Options That Close-Couple ITP to DWPF Operations}

OPTION 4: "Just-in-Time" (JT) precipitation in new stainless-steel facility.

Start ITP at the Tank Farm in smaller batches using a new stainless-steel facility just before DWPF startup. This could eliminate the need for a corrosion inhibitor and reduce the quantity of radiolysis organic products and benzene emissions by shortening the storage time. Option 4 would close-couple tank farm operation to the DWPF, creating a potential gridlock in Tank Farm, which needs to start up before DWPF to make room for the DWPF recycle stream. The gridlock could be offset by starting up ITP two years ahead of DWPF, as currently planned, and switching to JIT precipitation in the future, at which time Tanks 48 and 49 could be used to accept DWPF recycle waste. However, Option 4 could not meet the 6/94 radioactive operation startup date. Investment cost would be about equal to that of a Radiolysis Facility or Late Washing Facility; but Option 4 would not require any additional NaTPB. Technical certainty should be greater than or equal to the current ITP process because of the reduced storage time.

OPTION 5: "Just-in-Time" (JT) precipitation, using both Tanks 48 and 49, together with a new, small stainless-steel tank for washing.

This option was proposed by L. Lee and was deemed to have higher technical certainty than Late Washing. Would operate at high ionic levels $\left(5 \mathrm{M} \mathrm{Na}, 0.15 \mathrm{M} \mathrm{NO}_{2}^{-}\right)$using both Tank 48 and 49 for precipitation and concentration. Under these conditions, NaTPB would be precipitated in crystalline form during storage. The impact from release of the irradiation products (biphenyl, terphenyls) during washing and filtering is the main technical uncertainty. Would close-couple tank farm operation to the DWPF, creating a potential gridlock in Tank Farm which Tanks 48 and 49 would not be available to alleviate, as they are in Option 4 . However, this might become a very attractive option after the first five years or so of DWPF operation because of the ability to control sodium levels. On this basis, the radiolysis tank design should facilitate attachment of the crossflow filters for washing in a close-coupled operation.

This option was not further developed because of the degree to which ITP would be coupled to the DWPF during DWPF startup, as well as the similarity to Option 4. 


\subsubsection{Options That Deal with Ammonia Evolved in the CPC}

OPTION 6: add ammonia gas scrubbers in FAVC and RCT vents, add flush system on PVV filter.

OPTION 7: run FAVC HEME spray continuously (instead of separate scrubber), add flush system on PVV filter

The scrubber option was selected because of the precedent and operating success in the Separations Canyons. Design considerations may dictate which is eventually selected to scrub the ammonia.

\subsubsection{Option That Prevents Formation of Ammonium in the CPC}

OPTION 8: use nitric acid in SRAT.

Data from a single bench-scale experiment suggest this would greatly minimize the amount of hydrogen and ammonium formed in the SRAT. But it would have no impact on the amount of ammonium formed in the SPC and vented in the CPC, or on the organics problem. This is recommended as an accelerated development program because of the potential benefits in the CPC.

\subsubsection{Option That Reduces Organic Carryover in the CPC}

OPTION 9: physically separate the organic-coated solids before transferring the PHA to the boiling SRAT vessel and route them to the SME after cooldown. This entails allowing the solids to settle and decanting the clear aqueous phase to the SRAT.

This option was proposed by M. A. Baich. It does not address the ammonium nitrate problem but was deemed to have about $75 \%$ technical certainty for mitigating the organic carryover into the CPC vessel vent system.

\subsection{REJECTED OPTIONS}

Twenty-three other options were considered. Most addressed only a part of the problem. Many would require extensive research and development prior to implementation. All were deemed to have technical certainties $<50 \%$ and were therefore rejected.

OPTION 10: use steam/cooling jackets around SRAT/SME vent jumpers.

Partially addresses the organic problem, but only shifts the ammonium nitrate problem further downstream because it is a solid with finite vapor pressure.

OPTION 11: use absorber for ammonium (in liquid phase) or ammonium nitrate (in gas).

No "getters" for liquid-phase ammonium are currently identified; whatever chemical agent is used would require extensive testing to determine process impact. Relying solely on gas scrubbers would probably involve large equipment.

OPTION 12: incorporate explosion-proof design, rupture disc. 
Unknown impact of explosion on performance of sand filter. Changes would be very extensive, probable negative perception problems.

OPTION 13: add flush system on PVV header.

Uncertain what amount of ammonium nitrate buildup would be acceptable (if any) on the PVV filter or downstream (all the way to the sand filter). Probable major attainment loss to conduct the flush operation, "in-cell" changes would be extensive. Organics not mitigated. Flushing the PVV filter is recommended in conjunction with other options.

OPTION 14: catalytic combustion of ammonia.

Many of the possible catalysts are poisoned by mercury, no workable catalyst currently identified. Requires invention and lengthy demonstration.

OPTION 15: reroute the CPC vent.

Ammonium nitrate would still be formed in the new vent system. Preliminary calculations indicate that although ammonium nitrate has a significant vapor pressure, the air flow is not high enough to prevent accumulation (even in the sand filter).

OPTION 16: install ammonia gas scrubber in SPC vent.

Would neutralize the PR to evolve the ammonia, then scrub it as ammonium ion. Problem is where to route the scrubbed ammonium since benzene can potentially be present. Does not address the organic problem, or the ammonia formed in CPC.

OPTION 17: maintain acidic pH in SRAT.

Ammonium would be routed to melter (instead of being converted to ammonia and then being released to the vent system). No currently identified/demonstrated method is available to accomplish this; even when using nitric acid instead of formic acid (see Option 8), some pH rise would still occur.

OPTION 18: dewater PHA in PR and route PRBT to SME after cooldown.

Suggested by $L$. Lee and has previously been evaluated separately. A lengthy list of questions and uncertainties need to be addressed on this proposal. The Task Force did not review Lee's latest "response/rebuttal". Transfer of frit to SRAT was later found to be physically intractable.

OPTION 19: replace HAN with sulfamate or some other alternative.

OPTION 20: reduce HAN usage by supplementing with sulfamate, etc.

While partial substitution may be possible, glass quality limits on amount of sulfur and/or sulfate deposition in the melter off-gas system would prohibit totally replacing HAN with sulfamate. No other alternatives are currently identified; implementation depends on invention. Alternatives require extensive testing to determine process impact.

OPTION 21: reduce HAN usage to achieve an acceptable level of ammonium nitrate.

OPTION 22: don't use any HAN (but this would foul terribly). 
It is uncertain what amount of ammonium nitrate buildup would be acceptable (if any). Would aggravate the organic problem. Could be used to help reduce quantity of ammonium in conjunction with other options (ammonia scrubbers).

OPTION 23: eliminate nitrite and/or nitrate, or ammonium (e.g., by chemical oxidizer or electrolytic cell).

No method has been identified to accomplish this without also attacking the precipitate and generating tars, high-boilers, and oxidation products.

OPTION 24: Operate at higher concentration of precipitate solids (and then dilute supernate in PR).

Increasing the solids significantly would greatly affect the rheology (e.g.,"pumpability"), at least with fresh precipitate (as it would be if this were accomplished in ITP). Supernate could be decanted from aged precipitate in Tank 49, but it would contain high levels of cesium and organics (see Late Washing, Sections 4.1.2 and 6.2, and Option 2). Probably can't reduce nitrite from expected levels $(\sim 0.08 \mathrm{M})$ to the required value $(<0.01 \mathrm{M})$.

OPTION 25: minimize nitrite by additional washing.

OPTION 26: minimize nitrite by cooling waste tanks with chillers.

OPTION 27: ninimize nitrite by sampling with on-line analysis and using more frequent but smaller inhibitor additions.

Additional washing would reduce the nitrate level, thus reducing the nitrite requirement. Cooling the waste tanks would reduce the corrosion rate, also reducing the nitrite requirement. Obtaining more current sample results (without the drawbacks of the current sample method) would allow minimizing the amount of excess nitrite currently used.

While all these methods would have a desirable effect, they are not deemed to be sufficient to eliminate the problem (i.e., to reduce the nitrite to $<0.01 \mathrm{M}$ ). Depending on these "active" measures (especially chillers, samplers, analyzers) would necessitate a significant degree of redundancy to ensure reliability. The consequences of "failure" would be pitting failure of Tank 49 (not simply a batch to be reprocessed).

These steps could be utilized in conjunction with the other recommended long-term solutions to minimize the size of the new facilities and maximize the startup attainment, and are therefore included in the Generic Recommendations (Section 8.1).

OPTION 28: minimize nitrite by inhibiting with hydroxide (could use $\mathrm{LiOH}$ ).

Corrosion experts believe an oxidizing inhibitor is required so hydroxide could not be the sole inhibitor. Both hydroxide and nitrite are consumed by radiolytic reactions, so the sodium/lithium addition would actually increase (tending towards impacting glass formulation).

OPTION 29: use additional washings/cooling, to some level where inhibitor is not required.

Technical basis is lacking for operating without a corrosion inhibitor. Current inhibitor requirements allow for the presence of a certain amount of "other" aggressive anions (e.g., chloride, sulfate, floride), plus additional nitrite based on the amount of nitrate. With additional 
washing, all these anions could be removed to any desired extent. However, this would not eliminate the need for some form of corrosion inhibitor, as even pure water is corrosive to carbon steel.

OPTION 30: use an altemative/supplemental inhibitor (chromate, molybdate, borate).

All identified altematives are also expected to be affected by the organic decomposition/radiolysis products and many of these would impact glass quality.

OPTION 31: use a "non-chemical" corrosion inhibitor (e.g., cathodic protection).

Cathodic protection has previously been investigated and been ruled impractical (by the experts), due to the physical complexity of the waste tanks.

OPTION 32: set corrosion allowance for Tanks 48 and 49 (i.e., set their lifetime).

Without an inhibitor, the corrosion rate would be excessive (a matter of months for pits to penetrate the tank wall). Thus this is not a viable option (as it might be if the tank life were to be measured in years). 
1. J. T. Carter, D. H. Miller, R. E. Eibling, L. M. Lee, L. F. Landon, and J. C. Marek. Recommendations for Control of Ammonium Nitrate Deposits in the DWPF Process Vessel Vent System. WSRC-RP-91-1174, Westinghouse Savannah River Company, Savannah River Site, Aiken, SC (November 21, 1991).

2. D. D. Walker and B. S. Johnston. Radiolytically Induced Changes in the Concentrations of Nitrate and Nitrite Ions in Potassium Tetraphenylborate Slurries. DPST-86-716, E. I. Du Pont de Nemours and Co., Savannah River Laboratory, Aiken, SC (October 14, 1986).

3. M. Daniels and E. E. Wigg. Radiation Chemistry of the Aqueous Nitrate System. I. Gamma Radiolysis of Dilute Solutions. J. Phys. Chem. 71, 1024 (1967).

4. M. L. Hyder. The Radiolysis of Aqueous Nitrate Solutions. J. Phys. Chem. 69, 1858 (1965).

5. D. D. Walker. Benzene Distribution in Product Streams From In-Tank Processing. DPST-86-390, E. I. Du Pont de Nemours and Co., Savannah River Laboratory, Aiken, SC (January 15, 1987).

6. N. E. Bibler, personal communication.

7. D. D. Walker and B. A. Hamm. Material Balance and Planned Operating Schedule for the In-Tank Process (U). WSRC-RP-89-1303. Westinghouse Savannah River Company, Savannah River Site, Aiken, SC (December 27, 1989). 
Appendix A displays the authorization letter for establishment of the Nitrite Task Force. The letter outlines the problem, indicates the goals to be accomplished and the schedule to be followed, and lists the membership of the task force. 
WSRC-TR-91-664

Keywords: Nitrite; DWPF

cc: N. C. Boyter, 703-A

R. T. Begley, 773-A

R. Miller, 241-120H

C. Baker, 241-120H

D. L. Fish, 773-A

L. F. Landon, 704-T

H. H. Elder, 704-S

J. A. Gentilucci, 704-S

M. J. Plodinec, 773-A

J. T. Carter, 704-1T

C. B. Jones. $719-12 \mathrm{~A}$

J. M. McKibben, 704-S

SRL Records (4), 773-A

December 11, 1991

D. B. Amerine, Manager/DWPF

G. T. Wright, Manager/Waste Management

L. M. Papouchado, Acting Manager/DWP \& HT-SRL

TASK FORCE TO MITIGATE/ELIMINATE THE IMPACT OF SODIUM NITRITE ON THE DWPE

Process simulations in the Integrated DWPF Melter System (IDMS) at TNX have revealed the accumulation of ammonium nitrate (a known exposive) in the process vessel vent system during melter feed preparation processes as well as several operational problems due to the accumulation of non-polar organics. The presence the non-polar organics in the precipitate hydrolysis aqueous product (PHA) are at direct result of the corrosion inhibitor (sodium nitrite) added during In-Tank Precipitation to prevent pitting corrosion of the carbon steel waste tanks (Tanks 48 and 49). With the nitrite present, it is necessary to use hydroxylamine nitrate (HAN') in the DWPF Precipitate Hydrolysis Process to minimize the production of tars and non-polar organics; however, the HAN results in the formation of ammonium nitrate in the DWPF Chemical Processing Cell. The greater the nitrite concentration, the 
WSRC-TR-91-664

WSRC-TR-92-67, Rev 0

p. A-3

Page 2

December 11, 1991

greater the concentration of organics and ammonium ion in the PHA sent to the Chemical Process Cell. Without nitrite in the precipitate feed no HAN is needed in the Salt Processing Cell (SPC); the hydrolysis process thus produces PHA containing no ammonium ion and extremely low concentrations of non-polar organics.

Accelerated process and equipment development have been in progress by SRL; however, a straightforward chemical "fix" in the DWPF process alone, has not surfaced. At this time, it appears that the resolution of this problem will require process/equipinent modifications in both ITP and DWPF. To provide the best and most balanced path forward to resolution of this issue, the subject task force is being assembled to apply their expertise and technical judgement. Attachment 1, provides the definition of the task. Attachment 2 provides the current options logic diagram developed by DWPT for the DWPF process. Attactiment 3 provides the current options chart for the Tank Farm Processes. Altachments 2 \& 3 should be treated as a starting point by the team.

The Task Statement in Attachment 1 should be reviewed by the Task Force at their first meeting scheduled for December 12, 1991, 8:00 am in the 704-T Exhibit Room at TNX. At 10:00 am Dick Harral, Walt Tamosaitis, Joe Ortaldo, and Bill Holtzscheiter will join the Task Force meeting to address questions, clarifications, and modifications to the Task Statement in Attachment 1. For the remainder of the year, the Conference Room in 679-T at TNX has been reserved for the use of the Task Force.

The Task Force recommendations, as presented on the 19th of December, 1991 will be incorporated into the SRL, DWPF, and ITP Programs. The progress, will then be monitored in the Plan of the Week meetings of both DWPF and SRL. The success of this effort is key to providing a good and operable process for the DWPF Salt Processing Cell and to the timely removal and processing of salt currently stored in the Tank Farm.

Rf Less ht Rw/tome
R.W. Harral, Manager
Waste Management-Technical

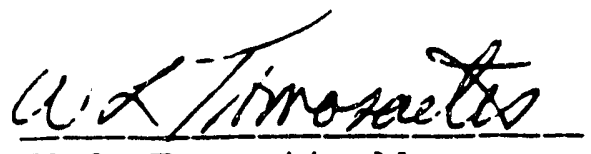

W. L. Tamosaitis, Manager Interim Waste Technology Savannah River Laboratory
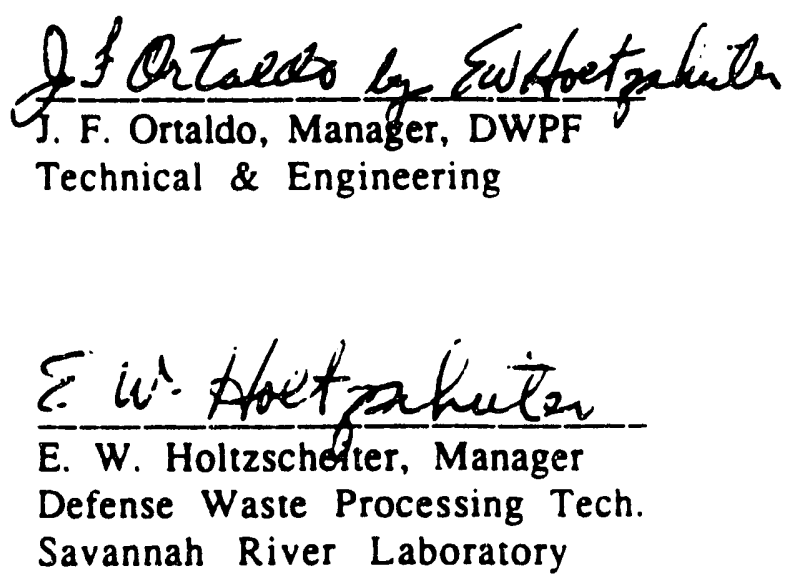


\section{\% 3 SK FORCE TO MITIGATE/ELIMINATE THE IMPACT OF SODIUM NITRITE ON THE DWPF}

\section{Purnose:}

This team is formed of the minimum number of experts in the required disciplines to rapidly evaluate options for mitigating or eliminating the impact of nitrite on the DWPF operations. The team's recommendations should provide a balance of technical risk, schedule attainment, and cost. The result of this effort is to provide the best path(s) forward for further development and demonstration. This result will also provide the basis for prioritizing the development and project expenditures.

\section{Required Product and Deliverables:}

1. Verbal presentation of the Task Force's evaluation of the options that the site has to mitigate or eliminate the impact on the DWPF of sodium nitrite introduced as a corrosion inhibitor in the tank farm. The options evaluations should include discussion of relative merit of the options and recommendations.

This presentation has been scheduled with Mr. Begley and Mr. Boyter for December 19. 1991 12-2 pm in 773-A , Conference Room A224.

2. Written report of the Task Force's evaluation of options and presentation of recommendations discussed in item 1 above should be complete 1/10/92.

\section{Precess:}

The evaluations of options should include the following:

- Review of the options evaluations prepared by SRL/IWT and SRL/DWPT. The options should be reviewed for completeness and revised and augmented as appropriate. 
WSRC-TR-91-664

- Evaluation for 1) technical risk/feasibility, 2) ability to mett 6/94 DWPF radioactive start-up milestone or realistic but fast-track alternate start-up date. 3) cost impact. Relative ratings should be reported for each option and for each of the above parameters.

- Resources outside the Task Force membership can be utilized via the appropriate L-3 Manager.

- Recommendations for paths forward based on the combined technical experise of the team.

\section{Resources:}

The following team of experts will be placed on full time special assignment effective December 12. 1991 through January 3, 1992. Vacation schedules should be adjusted to allow 100\% of your time starting December 12, 1991 through December 19, 1991 . Finalizing the report can be accomplished by all or part of the team allowing appropriate celebration of the holiday period.

$\begin{array}{lll}\text { Chairperson: } & \text { Jim Marek/DWPT } & \text { Precipitate Hydrolysis } \\ \text { Doug Walker/IWT } & \text { In-Tank Precipitation } \\ \text { Dave McGuire/DWPF } & \text { DWPF Technical/Salt Cell } \\ \text { Jack Nelson/Bechtel } & \text { Waste Mgt \& DWPF Projects } \\ \text { Phil Zapp/MTS } & \text { Corrison-DWPF \& Waste Mgt } \\ \text { Doug Brown/WM } & \text { ITP-Waste Management } \\ \text { Denny Bickford/DWPT } & \text { Glass Quality } \\ \text { Paul D'Entremont/WM } & \text { Waste Management-Tech. } \\ \text { Jim McGlenn/WM } & \text { Waste Management-ITP Ops }\end{array}$

Other Resources:

As indicated previously, other expertise will be provide as required through the appropriate L-3 Managers in DWPF, WM, SRL. 
ATTACHMENT 2

Op:ions chart for DWPF 

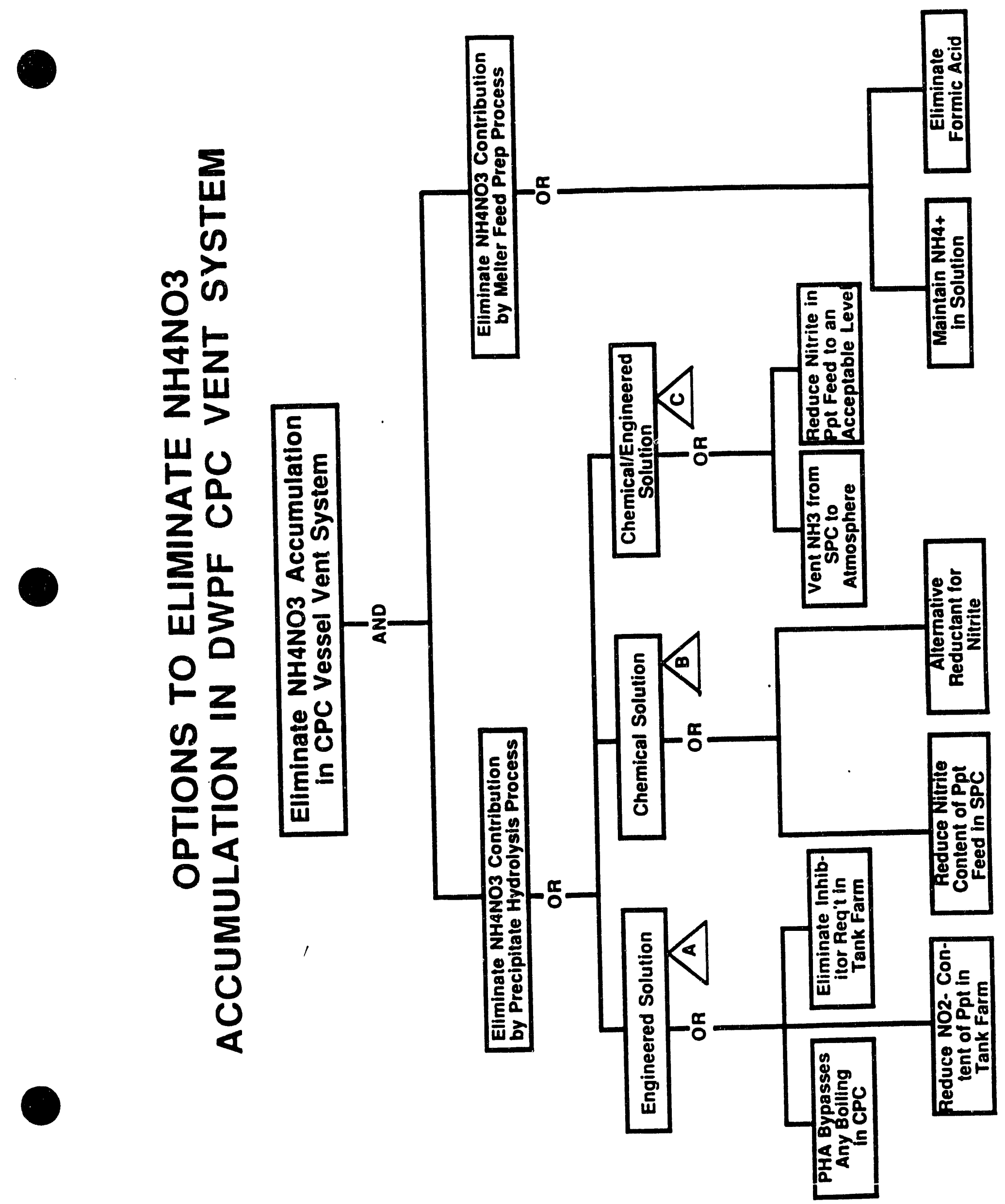


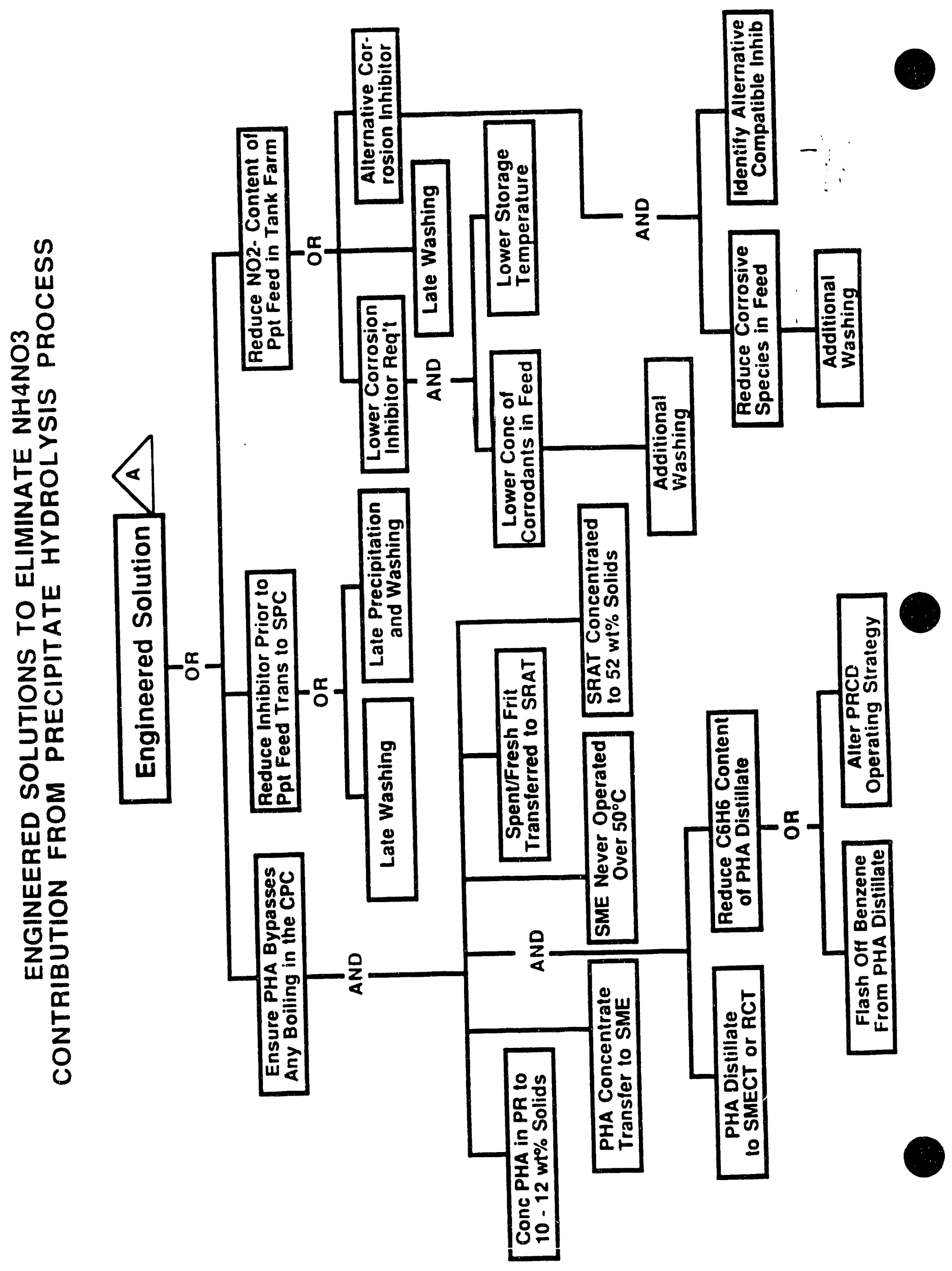



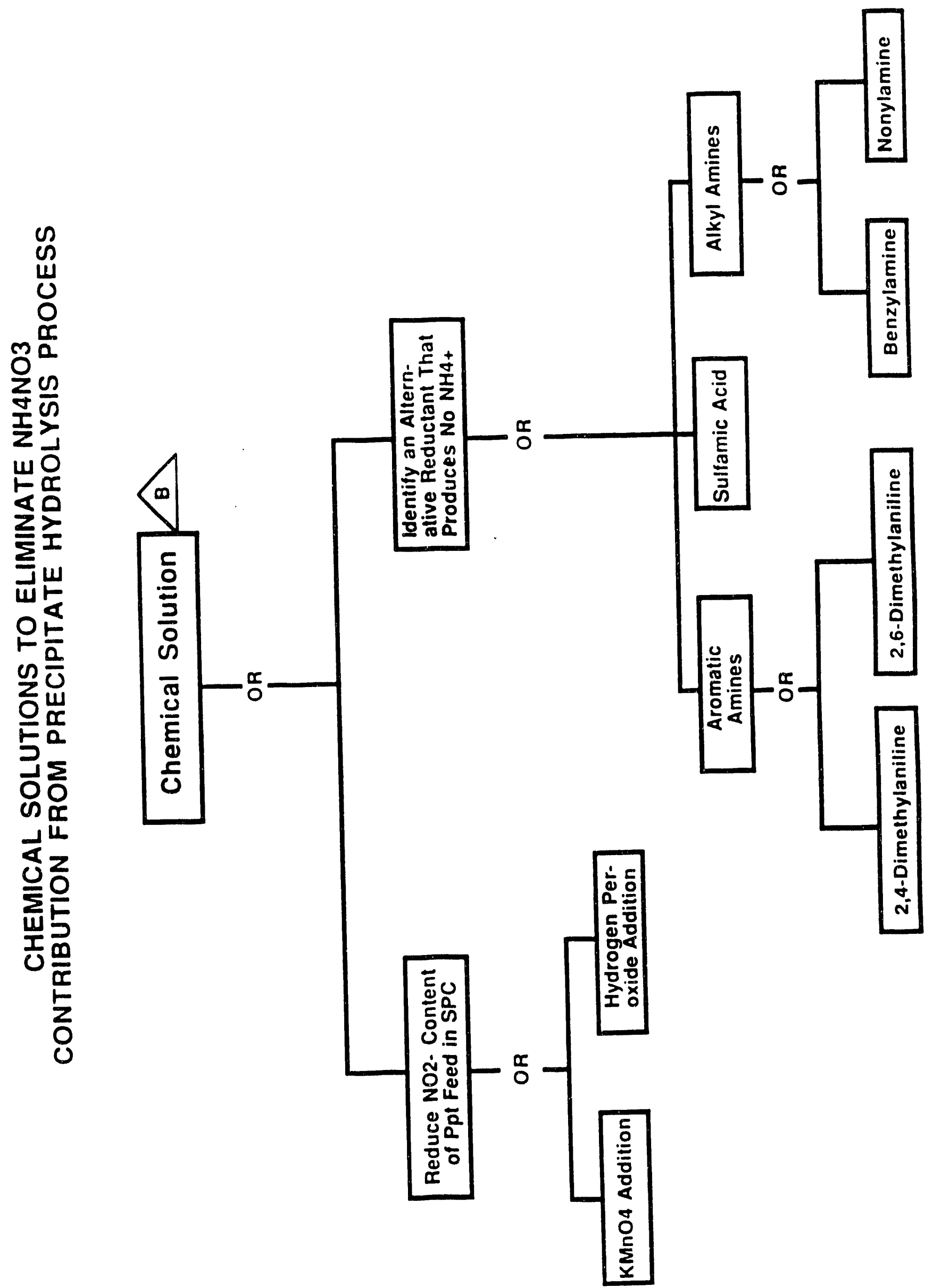


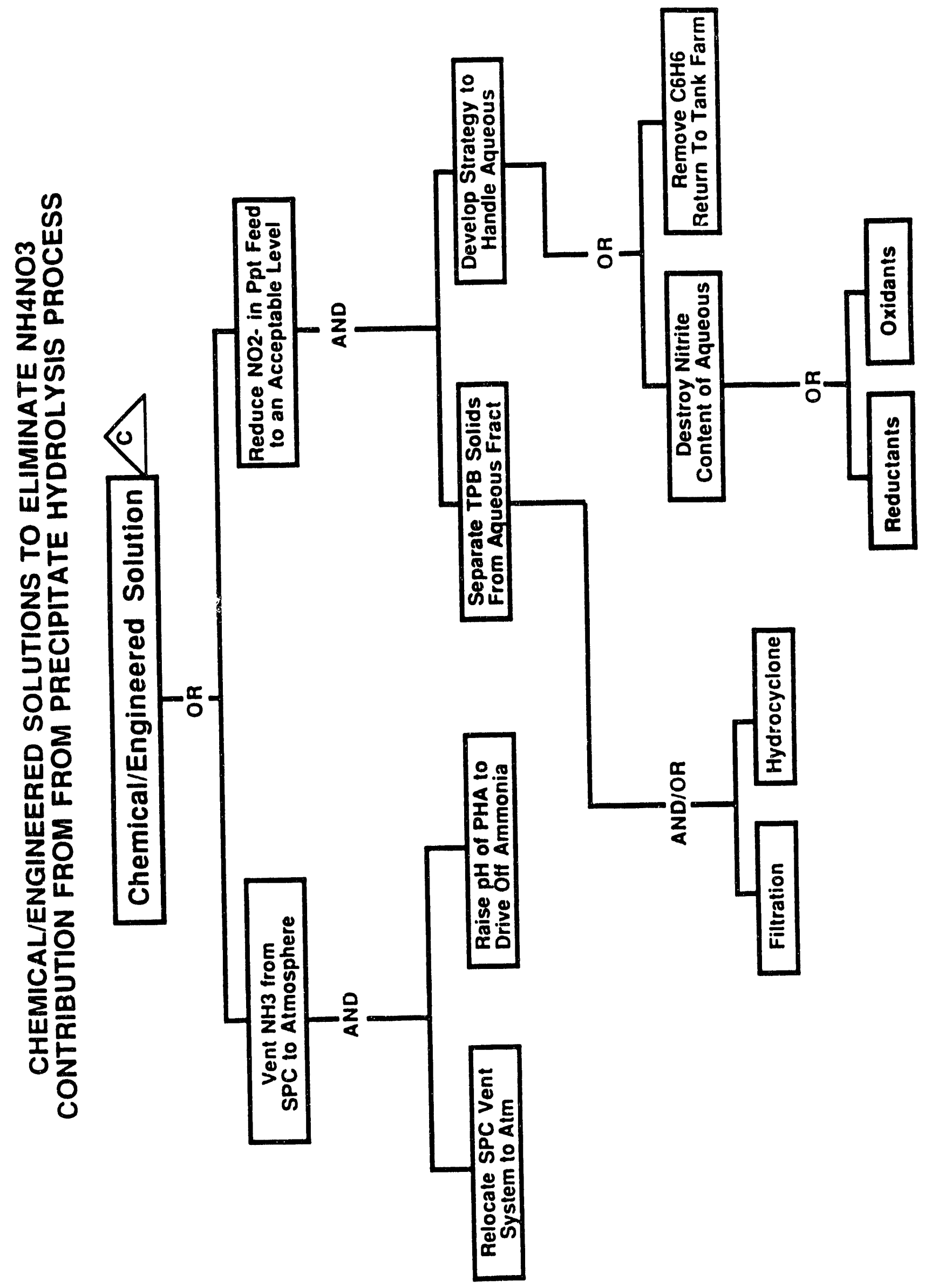


ATTACHMENT 3

Options chart for ITP 


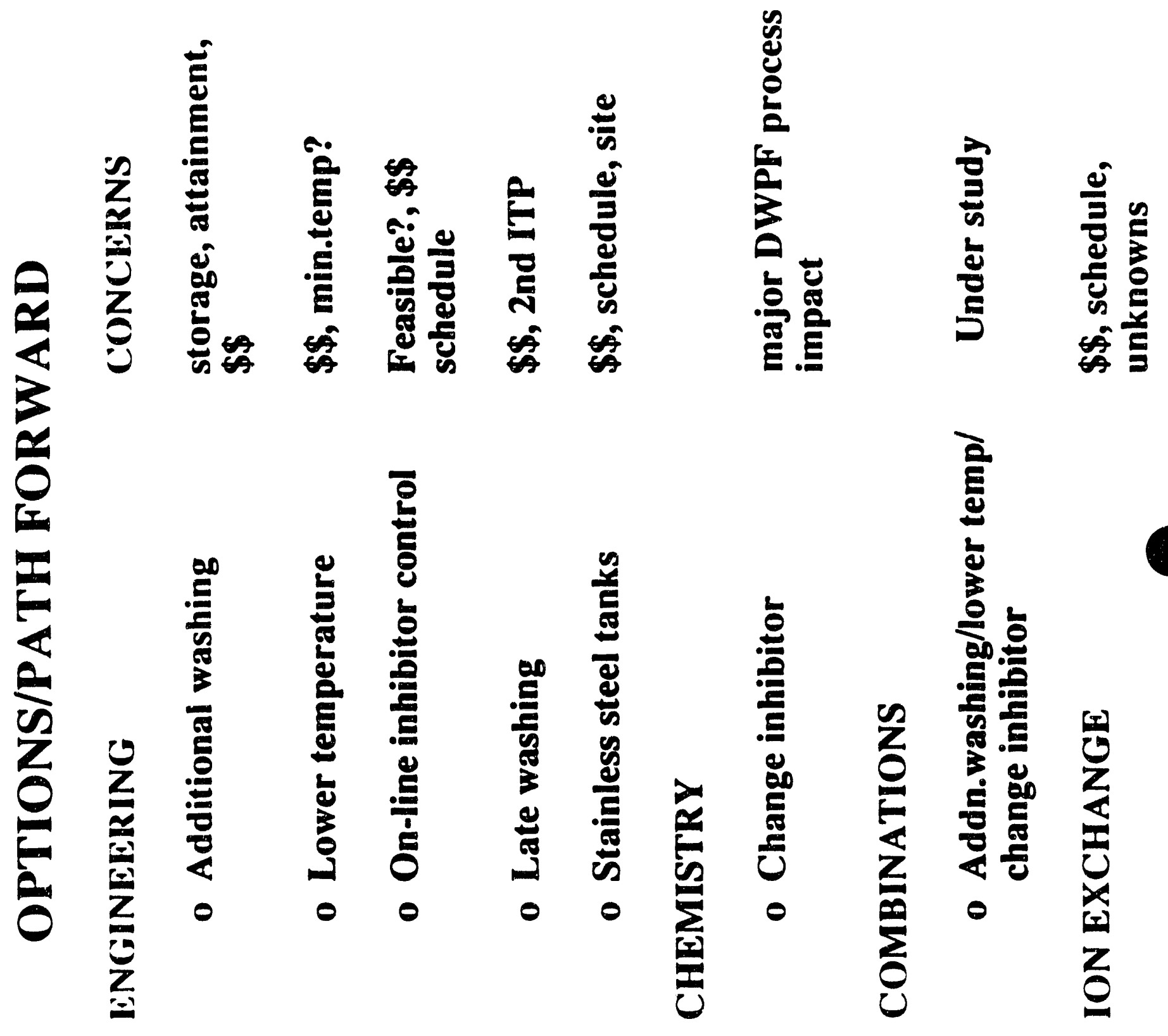



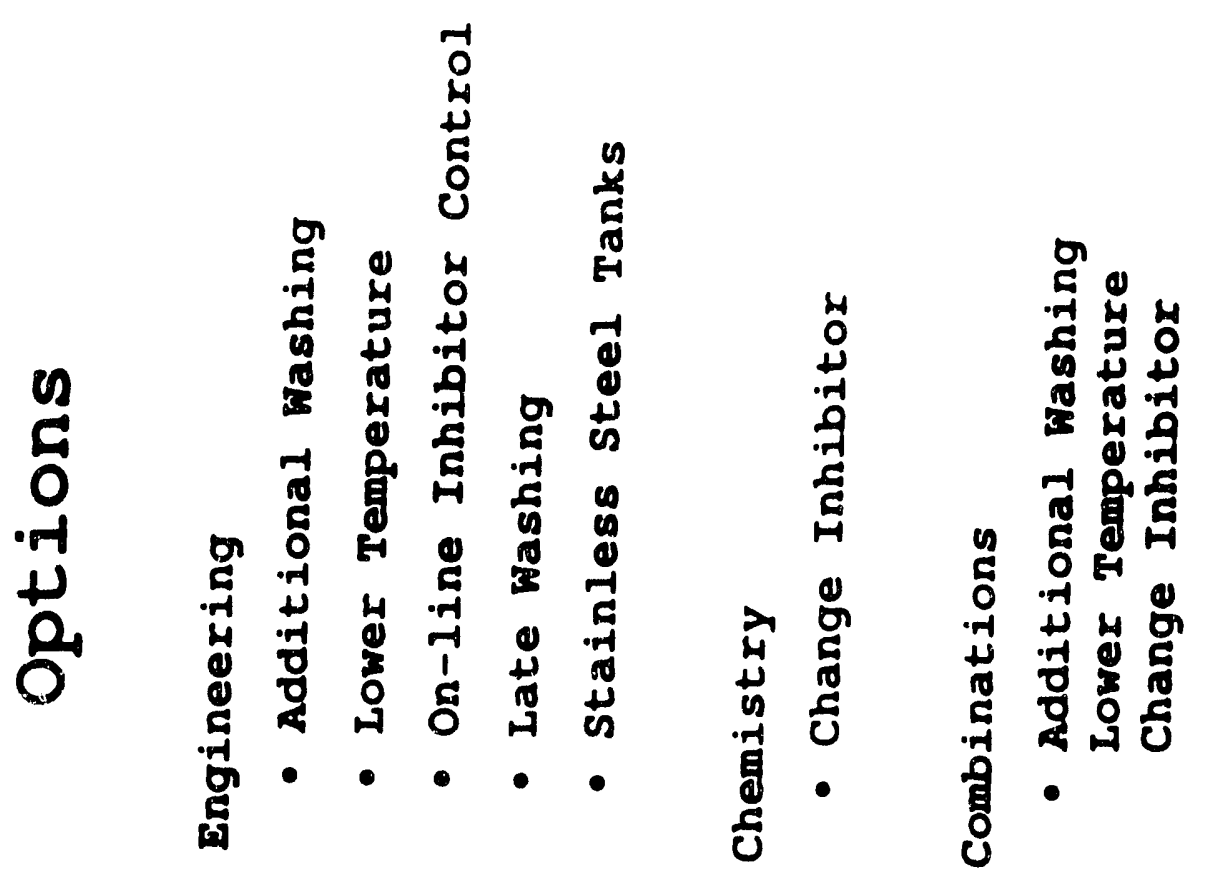


\section{CRITERIA FOR INITIAL CUT}

To be deemed worthy of further consideration, an option must be deemed to have a probability of success ("technical certainty") in excess of 50\% (see Section 6 and Section 9.1). Other options are to be rejected (see Section 9.2) at this time.

\section{OPERATIONAL, TECHNICAL, AND FINANCIAL CONSTRAINTS}

The following general goals were established:

- The option MUST MITICATE ammonium nitrate in the Chemical Process Cell vent system.

- It is DESIRABLE that the option ELIMINATE ammonium nitrate in the Chemical Process Cell vent system. The basis for the source terms was $90 \%$ of the total ammonium nitrate from the Salt Process Cell and 10\% of the total from the Chemical Process Cell.

- The amount of non-polar organic high-boilers should be reduced.

- Schedule for radioactive operations: MUST by 7/95, DESIRABLE by 6/94.

- Cost must be minimized.

- Impact on attainment must be minimized.

- Need for new equipment must be minimized.

- Complex operations should be avoided.

- Coupling of Tank Farm and DWPF operations should be minimized.

- Integrity of waste tanks MUST be maintained.

- Environmental impact MUST be minimized. All provisions of the Federal Clean Air Act must be satisfied. All EPA, OSHA, and SCDHEC regulations must be complied with.

- Safety features of DWPF equipment and procedures MUST NOT be degraded. All DOE orders must be complied with.

\section{ASSESSMENT PROCESS}

After brainstorming 32 options to mitigate the impact of nitrite on the DWPF, the Task Force undertook exhaustive discussion about the relative merits, drawbacks, potential advantages, and potential pitfalls of each option. Detailed development and evaluation of all 32 options was not compatible with the time resources allocated to the Task Force. The options were thus screened, using an Adelphi statistical approach to distribute them into two categories according to whether the projected probability of technical success was greater than or less than $50 \%$. This left the Task Force with two CPC options (vent system scrubbers and nitric acid sludge adjustment) and three SPC options (radiolytic nitrite destruction, late washing, and combined chemical and engineering SPC modifications to retain HAN and vent the ammonia). These options were then developed in greater detail as to their technical feasibility and risk, schedule, and cost. 
"Just-in-Time" precipitation was not included in the original list of options because of the degree to which it close-couples Tank Farm operations to DWPF operations. It was incorporated after the Task Force presentation when it became apparent that if selected, Tank 49 (and perhaps even Tank 48) would be available to provide waste storage during the DWPF startup and thus alleviate the coupling somewhat.

The remaining options were assessed by individual vote of each Task Force member for their effect on the following:

- Probability of success

- Reduction of ammonium nitrate from the SPC source term

- Reduction of ammonium nitrate from the CPC source term

- Attainment

- Degree to which equipment changes would be required

- Degree to which coupling would be increased/decreased

- Waste tank integrity

- Degree to which additional red tape (environmental and safety-related paperwork) would be created

- Engineering and Project man-months

- Schedule for SRL Basic Data and Technical Development

- Schedule for Project Engineering and Construction.

The values reported in the text of this report are for the "Probability of Success" portion of the Task Force rating process. "Just-in-Time" precipitation by definition has technical certainty greater than or equal to the current ITP process.

After determining the probability of success for mitigating ammonium nitrate accumulation, the Task Force assessed whether the SPC options also mitigated the organic high-boiler carryover problem. Because the combined chemical and engineering approach to vent the ammonium formed from HAN would result in no appreciable decrease in the organic high-boilers, the Task Force supplemented this option with the physical separation of the organic-coated solids. 


\section{APPENDIX C. PITTING CORROSION AND ITS INHIBITION IN CARBON. STEEL WASTE TANKS}

Dilute salt solutions containing tetraphenylborate solids are known to be corrosive to carbonsteel waste tanks. Under waste storage conditions, waste tank corrosion is inhibited with a high hydroxide concentration (1.0M). In ITP the hydroxide concentration is reduced by washing, by adsorption of atmospheric carbon dioxide, and by radiolysis. At the reduced hydroxide concentration, the tank wall and cooling coils become vulnerable to pitting.

Initially it is the steel immediately above the solution-air interface that is subject to pitting. An aqueous film develops on the steel and rapidly absorbs atmospheric carbon dioxide, which reacts with hydroxide to form cartonate and bicarbonate. Since the transport of hydroxide from the bulk solution into the film is very slow, the concentration of hydroxide is depleted and the pH drops to a steady-state value of about 9.5 in several hours from an initial $\mathrm{pH}$ of about 12 after washing. The $\mathrm{pH}$ of the bulk solution reaches 9.5 during the 2-year storage of washed precipitate slurry in Tank 49. Therefore, in the absence of other inhibitors, all wetted steel surfaces of that tank might eventually be attacked.

Five inhibitors were identified that can protect carbon steel from pitting when exposed to washed precipitate slurries. These were hydroxide, nitrite, chromate, carbonate, and pertechnetate. Nitrite was selected to inhibit washed precipitate because it is readily available and was deemed compatible with the DWPF. Minimum nitrite concentrations were established for inhibiting pitting corrosion. It was determined that nitrate, chloride, fluoride, and sulfate are the corrosive species in this system, and these ions were found to function independently in promoting pitting. That is, the required nitrite inhibitor concentration depended only on the concentration of a particular corrosive ion, when the concentration of that ion exceeded a critical concentration. Nitrate is the dominant corrosive ion in "fresh" washed precipitate. From laboratory tests at $40^{\circ} \mathrm{C}$, the required molar concentration of nitrite, including a safety factor, was found to depend on the nitrate molar concentration according to a polynomial expression:

$$
\left[\mathrm{NO}_{2}^{-}\right]=0.014+1.4\left[\mathrm{NO}_{3}^{-}\right]-2.5\left[\mathrm{NO}_{3}^{-}\right]^{2}+3.8\left[\mathrm{NO}_{3}^{-}\right]^{3}
$$

Nitrate is destroyed by radiolysis in Tank 49. As its concentration goes to zero, the dominant corrosive ion becomes sulfate. A constant nitrite concentration of $0.014 \mathrm{M}$ inhibits pitting under this condition at $40^{\circ} \mathrm{C}$. The temperature dependence of the nitrite concentration required to inhibit pitting was investigated from $2^{\circ} \mathrm{C}$ to $60^{\circ} \mathrm{C}$. The data were empirically fitted by the expression:

$$
\left[\mathrm{NO}_{2}^{-}\right]=0.0056 \mathrm{e}^{0.048 \mathrm{~T}}
$$

where $\mathrm{T}$ is the temperature in ${ }^{\circ} \mathrm{C}$. Lowering the temperature of Tank 49 to $30^{\circ} \mathrm{C}$ leads to a $40 \%$ reduction in the nitrite requirement. 


\section{APPENDIX D. RADIOLYSIS OF NITRATE AND NITRITE SOLUTIONS}

The radiolysis of aqueous nitrate and nitrite solutions has been extensively studied and the major features of this chemistry are well known. ${ }^{[3,4]}$ Recently, however, there has been renewed interest in nitrate and nitrite radiolysis in the presence of organic compounds. Organic compounds dramatically change the chemistry and lead to the formation of $\mathrm{N}_{2} \mathrm{O}$ gas. This reaction is believed to have contributed to the formation of flammable gas mixtures $\left(\mathrm{H}_{2}\right.$ and $\left.\mathrm{N}_{2} \mathrm{O}\right)$ in Hanford's Tank 101-SY and has been investigated at the Savannah River Laboratory in relation to the storage of potassium tetraphenylborate slurries in the In-Tank Precipitation Process. The basic features of this chemistry are described below.

The primary reactive species from the irradiation of alkaline aqueous solutions are the aqueous electron and hydroxyl radical:

$$
\begin{aligned}
\mathrm{H}_{2} \mathrm{O} & \longrightarrow \mathrm{e}^{-}(\mathrm{aq})+\mathrm{H}_{2} \mathrm{O}^{+} \\
\mathrm{H}_{2} \mathrm{O}^{+}+\mathrm{OH}^{-} & \longrightarrow \mathrm{OH}+\mathrm{H}_{2} \mathrm{O}
\end{aligned}
$$

In the absence of organic compounds, nitrate ion reacts with the aqueous electrons to produce nitrite ion:

$$
2 \mathrm{e}^{-}(\mathrm{aq})+\mathrm{NO}_{3}^{-}+\mathrm{H}_{2} \mathrm{O} \longrightarrow \mathrm{NO}_{2}^{-}+2 \mathrm{OH}^{-}
$$

There is also a back-reaction of nitrite with the hydroxyl radical which can regenerate nitrate or slow the formation of nitrite:

$$
2 \mathrm{OH}+\mathrm{NO}_{2}^{-} \longrightarrow \mathrm{NO}_{3}^{-}+\mathrm{H}_{2} \mathrm{O}
$$

The concentrations where Reaction (3) is balanced by Reaction (4) lie in favor of the nitrite ion. For example, if a $0.1 \mathrm{M}$ sodium nitrite solution is irradiated, no change is apparent in the nitrite concentration for doses up to 1000 megrads (within a few percent error). Similarly, irradiation of a $0.1 \mathrm{M}$ nitrate solution will produce $0.1 \mathrm{M}$ nitrite.

However, if organic compounds are present, it is found that both nitrate and nitrite disappear upon irradiation. Recent work has demonstrated that much of the nitrite is converted to nitrous oxide gas $\left(\mathrm{N}_{2} \mathrm{O}\right)$, although some was previously observed to form nitrated organic compounds. [5] The exact mechanism for $\mathrm{N}_{2} \mathrm{O}$ formation is not known at this time but is being investigated at Argonne and at Savannah River. Results from Savannah River show that the production of nitrous oxide gas is a general reaction and occurs with a wide variety of organic compounds (Table I). 


\section{TABLE I. Organic Compounds Which Form $\mathrm{N}_{2} \mathrm{O}$ Gas During} Irradiation in the Presence of Nitrate Ion.

\author{
Sodium acetate \\ Sodium tetraphenylborate \\ Benzene \\ Phenol \\ Tri-butylphospate \\ n-Paraffin \\ Acetone \\ Methanol
}

\author{
Ethanol \\ iso-Propanol \\ n-Butanol \\ tert-Butanol \\ Ethylene glycol \\ Dow Coming \#544 antifoam \\ Ethylenediaminetetraacetic acid (EDTA) \\ Ion-exchange resin
}

$\mathrm{N}_{2} \mathrm{O}$ does not appear to be formed in the presence of a few highly oxidized carbon species, such as carbonate and formate ions.

It has also been found that the rate of disappearance of nitrate is faster with organic compounds present than when they are absent. This is due to the scavenging effect of organics for hydroxyl radicals, which interferes with Reaction (4). This effect on nitrate radiolysis has been shown with several organic compounds, including formate ion, methanol, ethanol, and ethylene glycol.[6]

The rate of loss of nitrite ion has been studied for potassium tetraphenylborate slurries simulating the washed precipitate from the In-Tank Precipitation process. The results are shown in Figure 1. The rate of the reaction appears to be independent of the initial nitrite concentration and dependent on the radiation dose and organic precipitate concentration. The results for a $10 \mathrm{wt} \%$ slunry show that nitrite is lost at 0.84 molecules per $100 \mathrm{eV}$ of radiation energy deposited in the slurry (see figure below). Other tests have indicated that the rate of loss is directly proportional to the organic concentration. At the radiation levels expected in average washed slurry (36 Ci/gal), the rate of disappearance of nitrite is 0.010 molar/month. A earlier estimate of this rate was significantly lower ( 0.004 molar/month), [2] but it was made by curve fitting of data from experiments with high nitrate concentrations (i.e., the rate of loss of nitrite was not measured directly due to the high rate of conversion of nitrate into nitrite). The data in Figure 1 is probably be more accurate since it was a direct measurement without nitrate present, similar to the situation that will exist in Tank 49 (washed precipitate storage). However, further measurements are recommended to obtain higher confidence in the rate and to ascertain what factors may affect the rate. 


\section{Loss of Nitrite From Radiolysis}

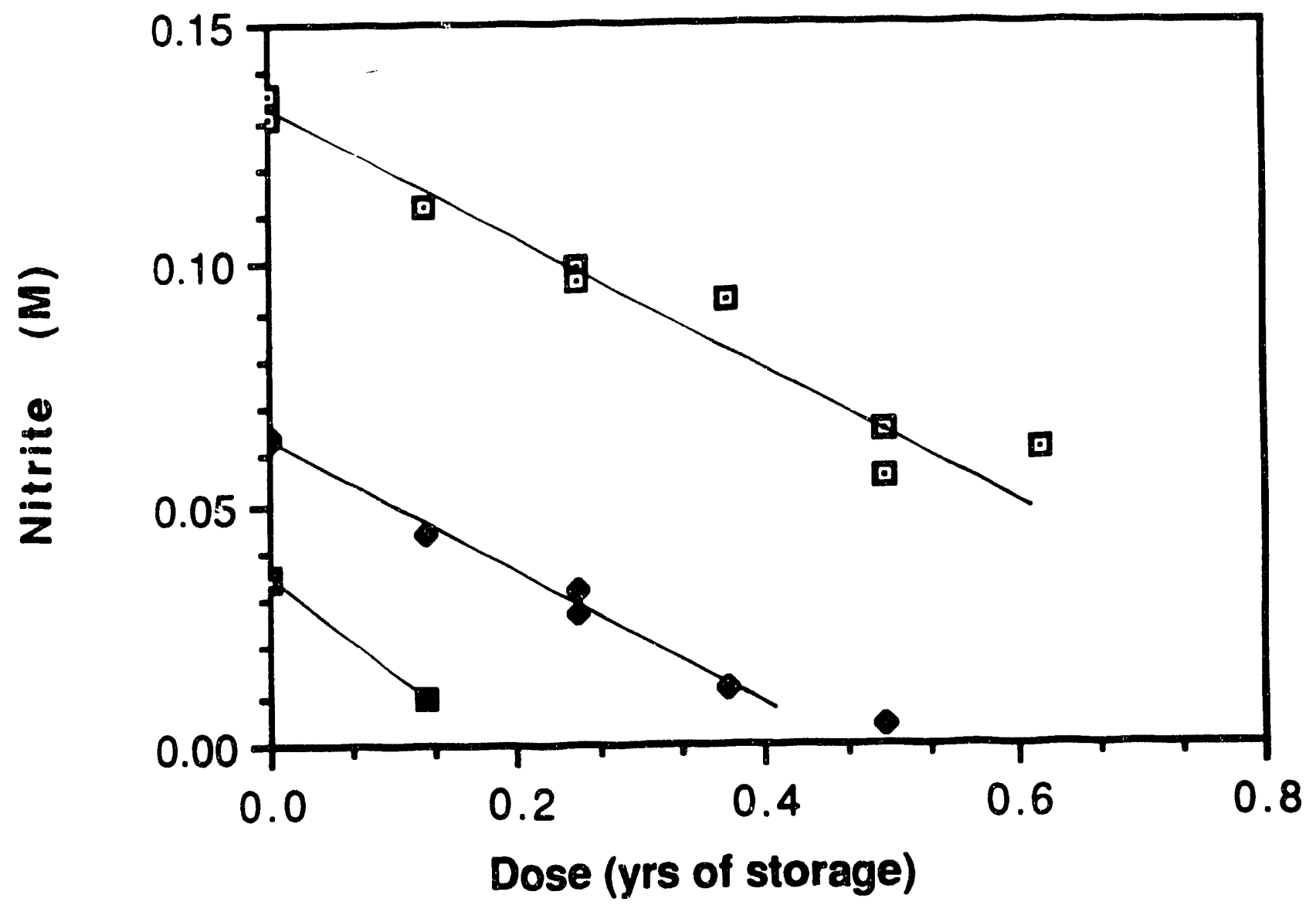

D-3 


\section{APPENDIX E. SUMMARY OF OPTION PROJECT SCHEDULE ESTIMATES}

Scope, cost estimates, and projected schedules are summarized below for three promising options previously discussed:

- Nitrite Radiolysis Facility (Section 6.1)

- Late (or Final) Washing (Section 6.2)

- Chemical Process Cell Modifications (Section 6.4).

Schedules are displayed in the five appended figures.

\section{NITRITE RADIOLYSIS FACILITY}

SCOPE: The Nitrite Radiolysis Facility will contain approximately one million gallons of double-walled, stainless-steel tankage. The facility will include transfer pumps, recirculating pumps or agitators for solid suspension, cooling coils for heat removal, inert gas blanketing facilities, off-gas filtering and monitoring facilities, slurry sampling facilities, leak detection facilities, and instrumentation. Size, shape, and location of this facility have not been determined at this time.

COST: The cost for these facilities is estimated to be in the $\$ 35$ to $\$ 50$ million range. This estimate is based on a current project estimate of \$54 million for installing two 750,000 gallon stainless-steel low-level waste tanks in the waste management facilities. These tanks do not include cooling coils or an inert gas blanketing system.

SCHEDULE: The sverall schedule for the nitrite radiolysis facility is about five years. The critical path components of the schedule are:

\section{PREPARE BASIC DATA REPORT}

Include time for SRL to verify that feed with low nitrite ion can be processed and to measure rates of nitrite destruction.

\section{DESIGN}

12 months

This includes time for Process Hazards Reviews, quality assessments, preparation of piping and instrument diagrams, equipment specifications, and equipment and piping layout drawings required for permit application.

\section{PERMIT APPROVAL}

12 months

This includes six months for DOE review and approval and six months for South Carolina DHEC approval.

This includes clearing, excavating, relocating underground line/ ductbanks, if required, and constructing the base mat. 
This assumes award of the subcontract at the time the permit is approved and that the subcontractor can procure and fabricate the initial quantities of corrosion-evaluated material in the six-month period required for base mat construction.

This is a parallel critical path to the base mat construction/tank erection path. It assumes that bidding and bid approvals are in place and that awards can be made when the permit is approved.

\section{FINAL CONSTRUCTION}

12 months

This includes construction of the concrete vault walls and roof, backfilling around the vault, installation of equipment, installation of cooling water piping, process piping, inert gas blanketing, off-gas processing facilities, and electrical.

OPERATIONS TESTING

2 months

TOTAL TIME

62 months

In conjunction with the nitrite radiolysis facility, the spare penetrations in the low point pump pit or the auxiliary pump pit should be extended prior to processing radioactive feed. This will allow tie-ins for the new nitrite radiolysis facility to be made with a minimum exposure to radiation. It is estimated that this will cost less than $\$ 1$ million, and can be completed in the first quarter of 1993.

\section{LATE (OR FINAL) WASHING}

SCOPE: $\quad$ Nitrite will be removed by reprecipitating and rewashing small batches of ITP product in a new stainless-steel facility before transfer to the DWPF (see Section 6.2.1). Process details are discussed in Section 6.2.2.

COST: The estimated cost is in the $\$ 50$ to $\$ 100$ million range.

SCHEDULE: SRLTechnical

Design/Project Engineering

Procurement/Construction

Checkout

TOTAL TIME
1 to 2 years

about 2 years (Conceptual, Title $1 \& 2$ )

2 to 3 years

$>1$ year

6 to 8 years (does not meet $6 / 94$ date for radioactive startup) 


\section{CHEMICAL PROCESS CELL MODIFICATIONS}

SCOPE: $\quad$ Replace vent line jumpers from the RCT and the FAVC with scrubber jumpers. Modify Process Vessel Vent Filter to allow periodic flooding to dissolve any ammonium nitrate deposits.

COST: The estimated cost is in the $\$ 3$ to $\$ 5$ million range. The estimate is an average of the individual estimates made by the members of the Task Team.

SCHEDULE: The overall schedule is approximately 2 years. The critical activities in the schedule are:

Develop Basic Data Report

Prepare design documents for Procurement

Procurement

(assumes no major equipment is required)

Construct and install new scrubber jumpers

Operations Test
6 months

6 months

6 months

6 months

3 months

TOTAL TIME

27 months 


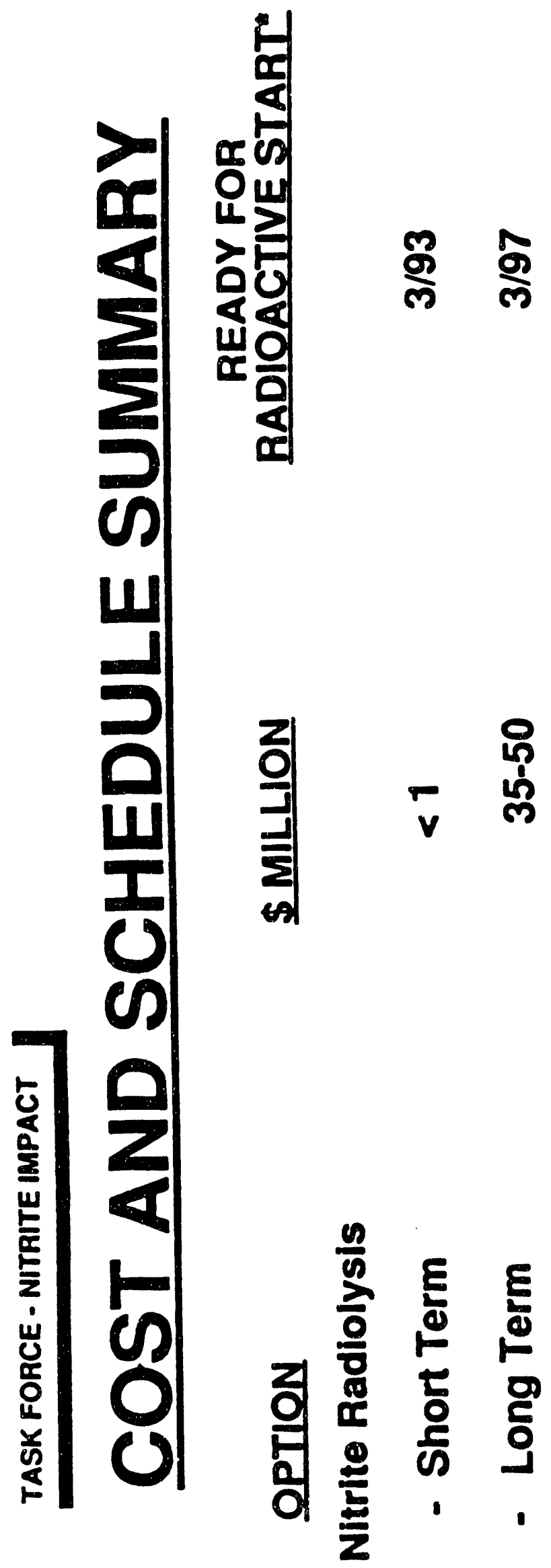

के

$\frac{8}{8}$

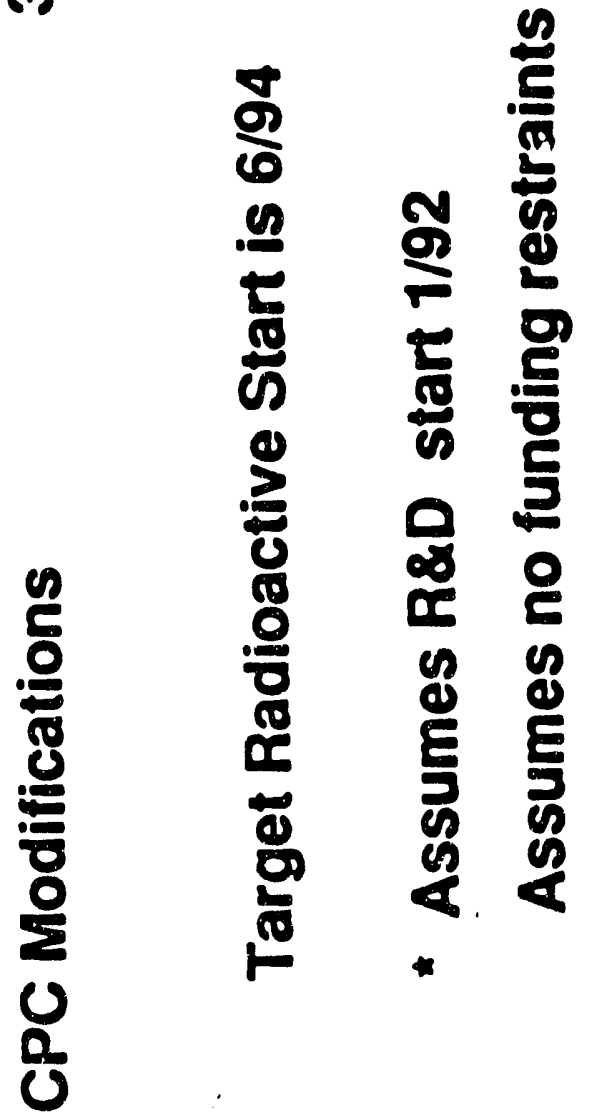




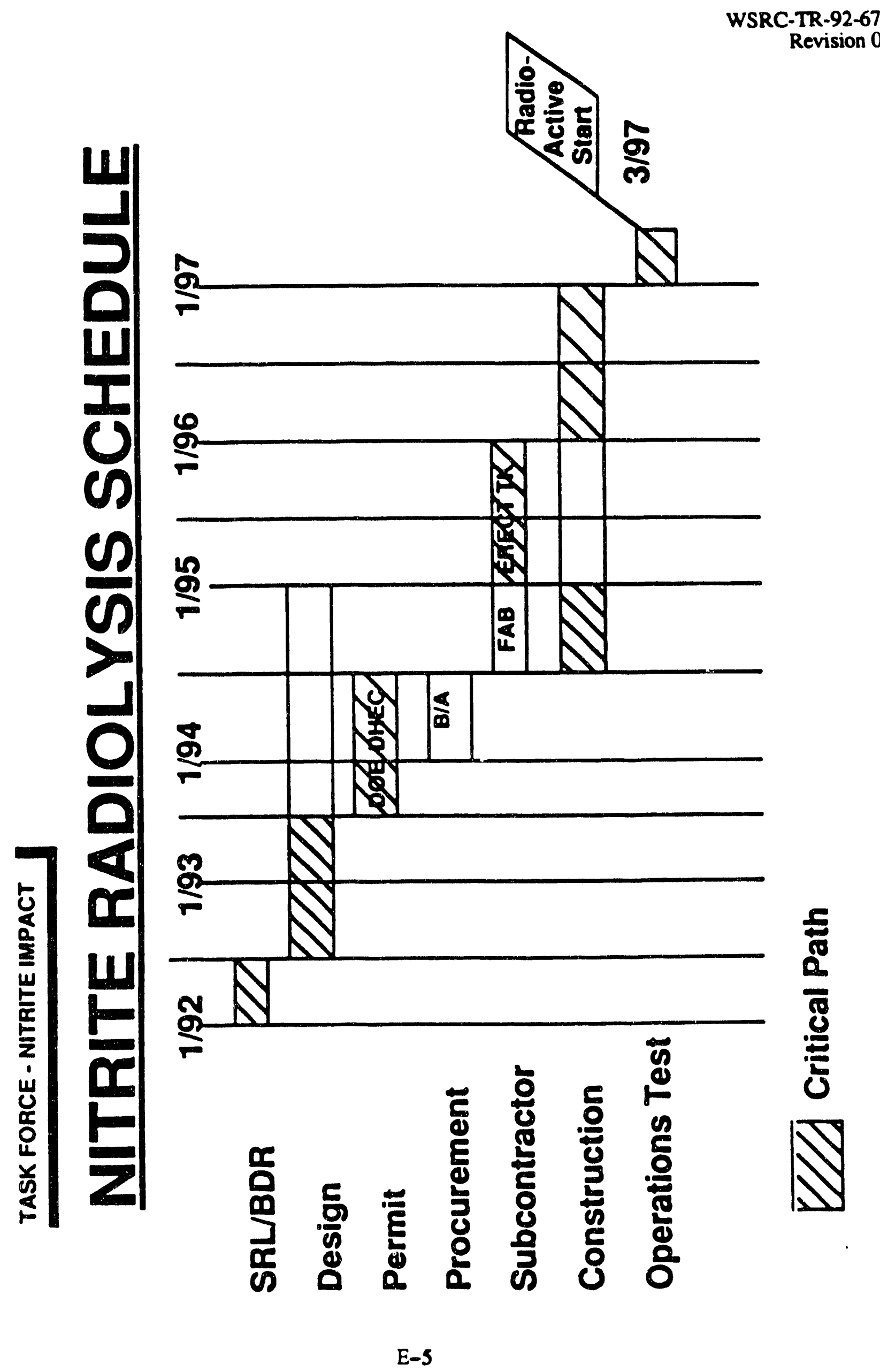



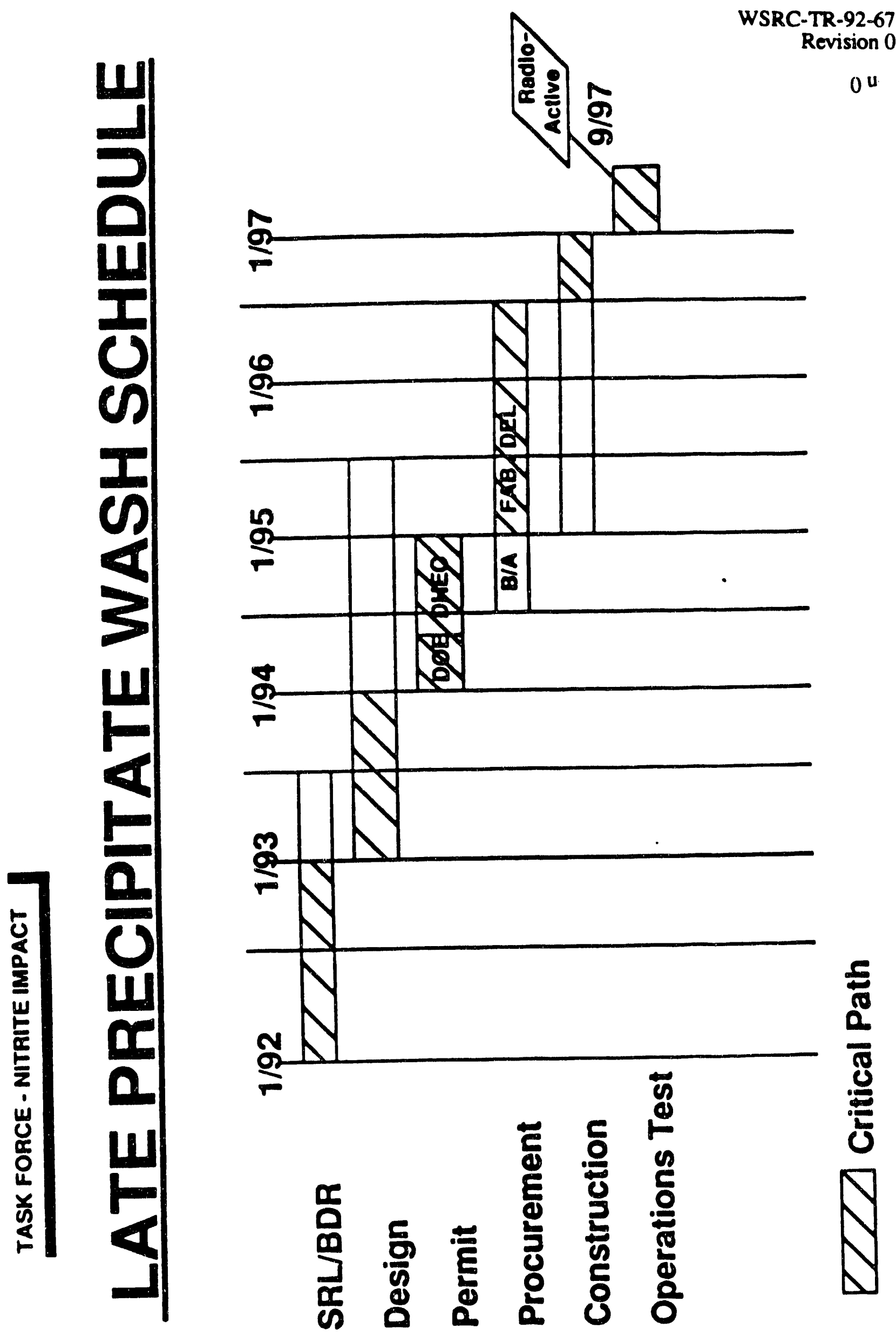

E-6 


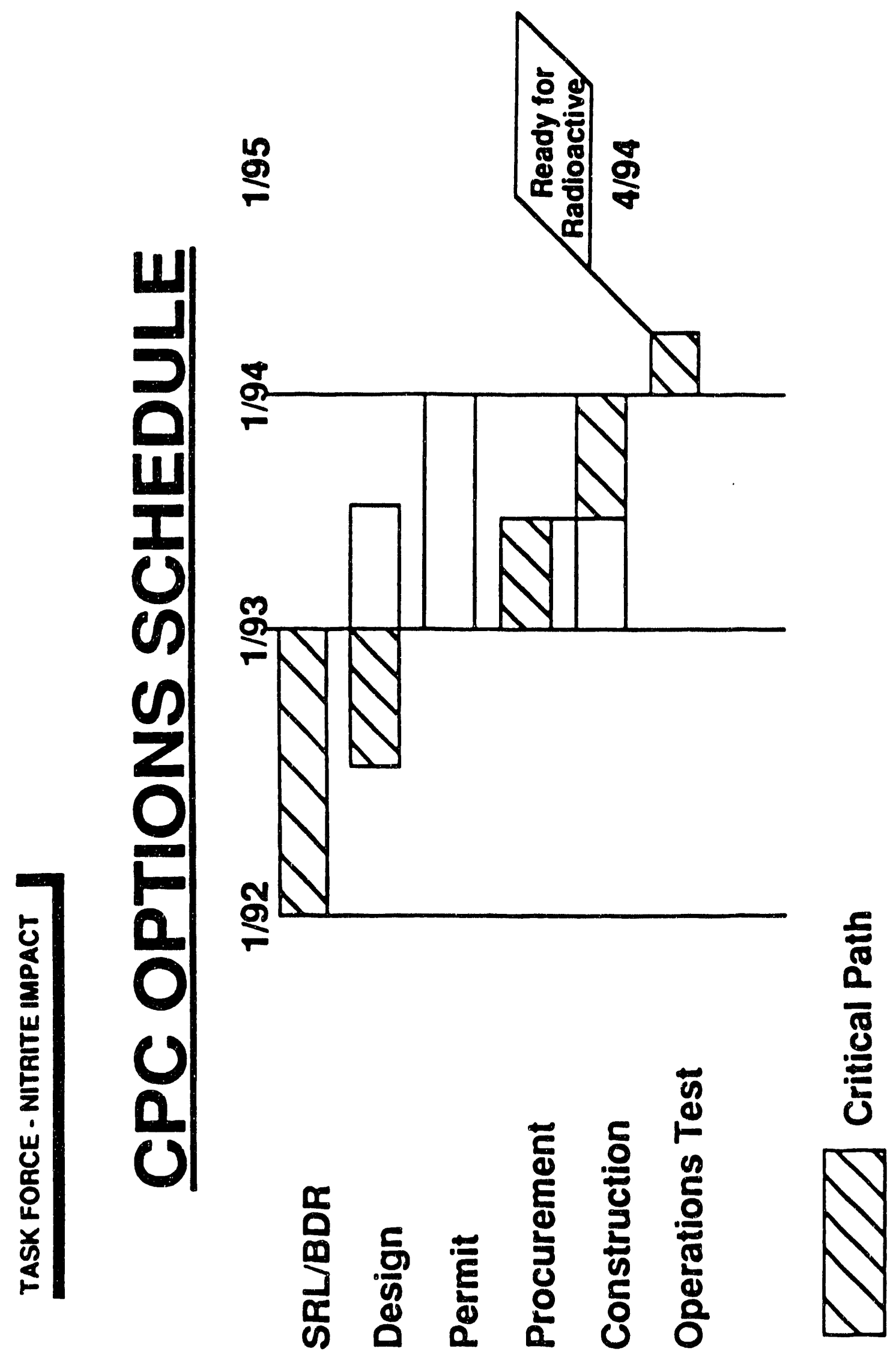




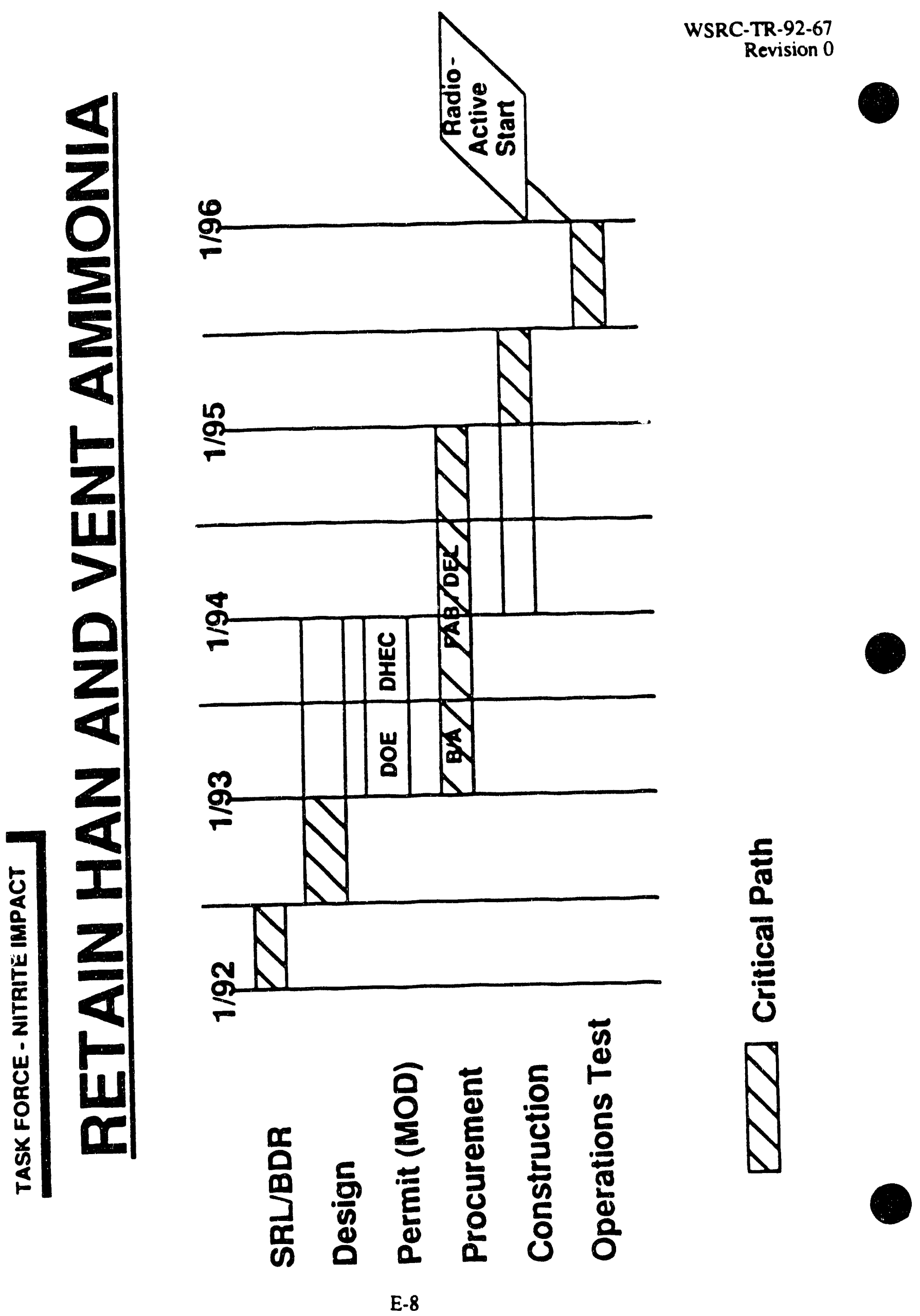




\section{APPENDIX F. SIZING THE NITRITE RADIOLYSIS FACILITY AND ATTAINMENT ESTIMATES FOR THE PUMP-PIT STARTUP WORKAROUND}

This approach is discussed in Section 6.5, "Workaround Option for Startup: Pump Pit Radiolysis," and briefly mentioned as Option 1 ("Radiolysis of Nitrite") in Section 9.1.1. Two ways of implementing Option 1 are discussed below.

\section{OPTION 1A: USE OF SINGLE LARGE TANK}

Under this option, a single large, stainless-steel tank is constructed to hold the washed precipitate between Tank 49 and the DWPF. The tank is sized to hold the washed precipitate while radiolysis decomposes the nitrite. The size of the tank depends on the required feed rate to the DWPF, the nitrite concentration in the slurry from Tank 49, and the radioactivity level in the precipitate. The effect of these variables is shown in Table II, based on a nitrite decomposition yield of 0.80 molecules $/ 100 \mathrm{eV}$ (slightly conservative in comparison with the measured 0.84 molecules/100 eV cited on p. D-2).

\section{TABLE II. Tank Size Required to Reduce Nitrite Concentration to Less than 0.1M} Required Tank Size (gallons) as a Function of Nitrite Concentration (M) in Tank 49

\begin{tabular}{|c|c|c|c|c|c|}
\hline Nitrite (M): & $\underline{0.030}$ & 0.040 & $\underline{0.050}$ & $\underline{0.060}$ & $\underline{0.070}$ \\
\hline & \multicolumn{5}{|c|}{ Attainment $=405,000 \mathrm{gal} / \mathrm{yr}$} \\
\hline \multirow[t]{2}{*}{$\begin{array}{r}36 \\
18 \\
7.2\end{array}$} & $\begin{array}{r}68,000 \\
135,000 \\
338,000\end{array}$ & $\begin{array}{l}101,000 \\
203,000 \\
506,000\end{array}$ & $\begin{array}{l}135,000 \\
270,000 \\
675,000\end{array}$ & $\begin{array}{l}169,000 \\
338,000 \\
844,000\end{array}$ & $\begin{array}{r}202,000 \\
405,000 \\
1,012,000\end{array}$ \\
\hline & \multicolumn{5}{|c|}{ Attginment $=525,000 \mathrm{gal} / \mathrm{yr}$} \\
\hline $\begin{array}{r}36 \\
18 \\
7.2\end{array}$ & $\begin{array}{r}88,000 \\
175,000 \\
438,000\end{array}$ & $\begin{array}{l}131,000 \\
262,000 \\
656,000\end{array}$ & $\begin{array}{l}175,000 \\
350,000 \\
875,000\end{array}$ & $\begin{array}{r}219,000 \\
438,000 \\
1,094,000\end{array}$ & $\begin{array}{r}263,000 \\
525,000 \\
1,312,000\end{array}$ \\
\hline
\end{tabular}

The two attainment rates are based on ITP and DWPF plans. The current material balance for ITP shows a precipitate production rate of 405,000 gallons per year (at $75 \%$ attainment). ${ }^{\text {[7] }}$ This is $25 \%$ lower than the DWPF design basis of $525,000 \mathrm{gal} / \mathrm{yr}$ (at $75 \%$ attainment).

The nitrite concentration in Tank 49 is set by Operational Safety Requirements and depends on the temperature and nitrate levels in the slurry. The minimum nitrite requirements is $0.014 \mathrm{M}$ when no nitrate is present. By operational adjustments to In-Tank Precipitation (such as extra washing), the required level can approach $0.014 \mathrm{M}$. The excess above $0.014 \mathrm{M}$ at which the Tank Farm will run will depend on the frequency of sampling and analysis, analytical errors, and the rate of change of the nitrite concentration. Table II covers the expected range of potential nitrite levels due to these factors. 
Cesium-137 levels in waste will also vary. The current CPES ${ }^{*}$ material balance would produce a washed $10 \mathrm{wt} \%$ precipitate slurry containing $36 \mathrm{Ci}$ of $\mathrm{Cs}-137$ per gallon.[7] At lower cesium levels, the rate of loss of the nitrite would decrease. The effect on tank size of reductions of Cs137 by as much as $\mathbf{8 0 \%}$ are shown in Table II. It has been estimated from the volume of precipitate and the radioactivity levels in the waste process during the first five years of ITP operation that the average Cs-137 activity would be $23 \mathrm{Ci} / \mathrm{gal}$, about $40 \%$ below the current CPES value.

\section{OPTION 1B: STARTUP WITH AVARABLE TANKAGE}

Although it is unlikely that sufficient stainless-steel tankage could be built in time for the scheduled DWPF startup, it is possible to begin hot operations at a greatly reduced attainment by using currently available tankage. The available tankage consists of the two pump-pit tanks (working volumes of 4,700 gallons each) and the Precipitate Reactor Feed Tank (working volume 7,400 gallons). Precipitate could be transferred to these tanks and allowed to age while the nitrite decomposes, then sent to the Salt Process Cell. The workoff time for 16,800 gallons would be 9 days. The net attainment for the DWPF is shown in Table III. Very low attainment rates are possible, but they could be significantly increased by adding additional tankage.

\section{TABLE II. Attainment Using Current Tankage}

Nitrite $M$ in Tank 49 \% Attainment*

$\begin{array}{ll}0.030 & 8.4 \\ 0.040 & 5.8 \\ 0.050 & 4.4 \\ 0.060 & 3.5 \\ 0.070 & 3.0\end{array}$

*Based on $23 \mathrm{Ci}$ Cs-137/gallon of slurry, $100 \%$ attainment $=700$, 0 in $\mathrm{gal} / \mathrm{yr}$

* $\mathrm{CPES}=$ Chemical Process Evaluation System, a Du Pont proprietary program. 
WSRC-TR-92-67

Revision 0

APPENDIX G. CONCEPTUAL DESIGN OF A NITRITE RADIOLYSIS FACILITY 
Bechtel

Savarran River Sile

BNISC DWPF

PO $30 x+16$

New E enton. SC 29809.0116

January 29, 1992

Mr. M. L. Stephenson

Senior Project Manager

Westinghouse Savannah River Company

Savannah River Site

Aiken, South Carolina 29801

SAVANMAH RIVER SITE - 200-AREA

DEFENSE WASTE PROCESSING FACILITY

CONTRACT AXC-1997-W JOB NO. 13239

S-1780 RELATED ACTIVITIES

BECHTEL NATIONAL, INC. SITE OFFICE (BNISO)

NITRITE RADIOLYSIS FACILITY, REACTOR SIZING STUDY

Dear Mr. Stephenson:

Enclosed is a study of reactor sizes for the Nitrite Radiolysis Facility. The study was done to determine the affect of the following parameters on the reactor size required:

1. Number of Reactors

2: Cèsium Concentration in Precipitate Feed

3. Tank 49 Operating Temperature

4. Tank 49 Sample Cycle.

If you have any questions, please contact J. W. (Jack) Nelson, extension 7-2994.

Very truly yours,

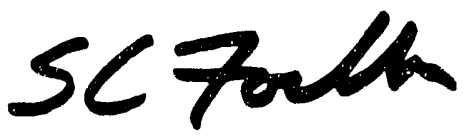

S. C. Foelber

Project Engineering Manager

SCF/JWN/phb

Enclosure

\section{5}

$30-14396$ 
Mr. M. L. Stephenson

January 29, 1992

Page 2

CC: All w/encl.

\section{NSRC}

H. K. Bethmann

J. E. Meek

L. F. Landon (704-T)

J. C. Marek (704-T)

D. H. McGuire (704-27S) PRC
BSRI

J.E. Crain
BNISO

D. L. Ketcham

J. W. Nelson

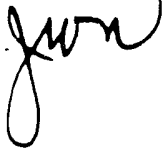


J. W. NELSON

BECHTEL NATIONAL, INC.

JANUARY 1992 
TABLE OF CONTENTS

INTRODUCTION

BASES OF STUDY

1

SUMTIARY

2

DISCUSSION

4

NITRITE CONCENTRATION VS TIME GRAPHS

BLOCK FLOW DIAGRAM

FIG. 1

CONCEPTUAL LAYOUT PLAN

FIG. 2

CONCEPTUAL LAYOUT - SECTION

FIG. 3

CALCULATIONS

APPENDIX A

FORMULAE

APPENDIX B 


\section{NITRITE RADIOLYSIS FACILITY (NRF) REACTOR SIZING STUDY}

\section{INTROOUCTION}

In December 1991, a task force was convened to address the problem of ammonium nitrate and non-polar organic accumulation in the TNX-IDMS Vessel Vent System and the potential impact on DWPF operation. The task force concluded that the major source of ammonium resulted from the destruction of nitrite in the precipitate feed using hydroxylamine nitrate (HAN) and the best way to minimize ammonium nitrate formation was to reduce the nitrite in the precipitate feed to DWPF. Feed with less than $0.01 M$ nitrite can be processed without the use of HAN. This also will reduce the amount of non-polar organics produced.

Nitrite ion is used as corrosion inhibitor in the carbon steel waste Storage Tanks, but nitrite ion is also destroyed by radiation in the presence of organic material.

The task force recommended that stainless steel reactors be installed between TK-49 and DWPF, to allow radioactivity to destroy the nitrite ion.

This study was done to determine the affect of the following parameters on the size of stainless steel reactors required:
-1i. Single Reactor vs Multiple Reactors
2. Cesium Concentration
3. Tank 49 Operating Temperature
4. Tank 49 Sample Cycle.

\section{BASES OF STUDY}

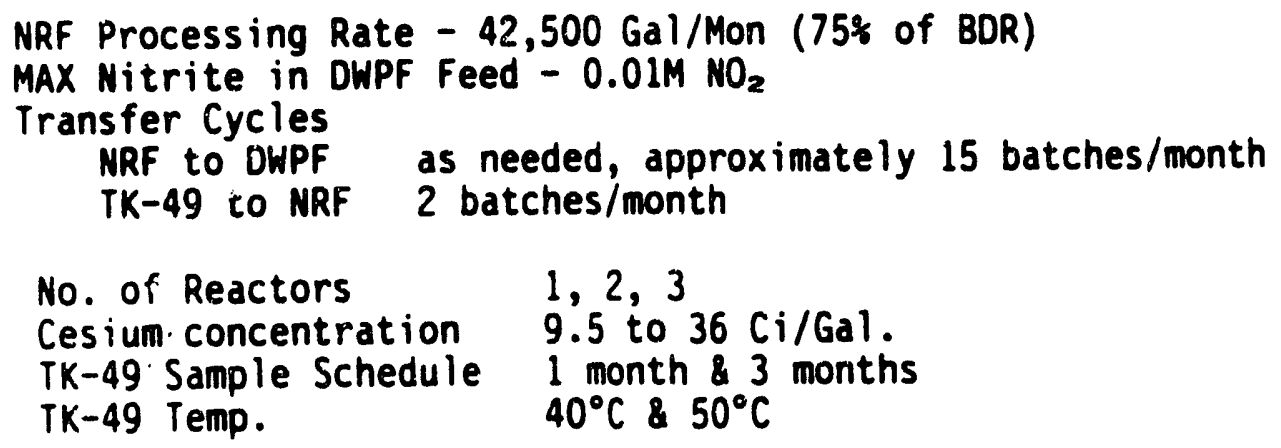


SUMMARY

SINGLE REACTORS VS. MULTIPLE REACTORS:

The number of reactors has a minor impact on the total volume required.

\begin{tabular}{|c|c|c|c|c|c|}
\hline Case & $\begin{array}{c}C s \\
\mathrm{Ci} / \mathrm{Gal} \\
\end{array}$ & $\begin{array}{l}\text { TK-49 } \\
\text { Temp } \\
{ }^{\circ} \mathrm{C} \\
\end{array}$ & $\begin{array}{l}\text { TK- } 49 \\
\text { Sample } \\
\text { Cycle, Mon }\end{array}$ & $\begin{array}{l}\text { NRF Reactors } \\
\text { Required } \\
\text { No. Gals. }\end{array}$ & $\begin{array}{l}\text { Total } \\
\text { Volume } \\
\text { Percent } \\
\end{array}$ \\
\hline $\begin{array}{l}1 \\
2 \\
3\end{array}$ & $\begin{array}{l}36 \\
36 \\
36\end{array}$ & $\begin{array}{l}50 \\
50 \\
50\end{array}$ & $\begin{array}{l}3 \\
3 \\
3\end{array}$ & $\begin{array}{lr}1 & 200,000 \\
2 & 95,000 \\
3 & 62,000\end{array}$ & $\begin{array}{r}100 \\
95 \\
93\end{array}$ \\
\hline
\end{tabular}

CESIUM CONCENTRATION:

Cesium concentration in the feed has a major impact of volume required.

\begin{tabular}{|c|c|c|c|c|c|}
\hline ase & $\begin{array}{c}\text { Cs } \\
\text { Ci/Gal } \\
\end{array}$ & $\begin{array}{l}\text { TK-49 } \\
\text { Temp } \\
{ }^{\circ} \mathrm{C} \\
\end{array}$ & $\begin{array}{l}\text { TK-49 } \\
\text { Sample } \\
\text { Cycle, Mon }\end{array}$ & $\begin{array}{l}\text { NRF Reactors } \\
\text { Required } \\
\text { No. Gals. }\end{array}$ & $\begin{array}{l}\text { Total } \\
\text { Volume } \\
\text { Percent } \\
\end{array}$ \\
\hline $\begin{array}{l}2 \\
4 \\
5 \\
6 \\
7\end{array}$ & $\begin{array}{r}36 \\
23 \\
19 \\
13 \\
9.5\end{array}$ & $\begin{array}{l}50 \\
50 \\
50 \\
50 \\
50\end{array}$ & $\begin{array}{l}3 \\
3 \\
3 \\
3 \\
3\end{array}$ & $\begin{array}{rr}2 & 95,000 \\
2 & 120,000 \\
2 & 140,000 \\
2 & 170,000 \\
2 & 200,000\end{array}$ & $\begin{array}{l}100 \\
126 \\
147 \\
179 \\
210\end{array}$ \\
\hline
\end{tabular}

Where $36=$ Average All Waste

$23=$ Average First $5 \mathrm{yr}$. Waste

19 = Minimum First 5 yr. Waste

$13=$ Minimum First 5 yr. Waste with $1.5 x$ Safety Factor

$9.5=$ Minimum First 5 yr. Waste with $2 x$ Safety Factor

TK-49 OPERATING TEMPERATURE:

Operating Tank 49 at $40^{\circ} \mathrm{C}$ rather than $50^{\circ} \mathrm{C}$ would reduce the NRF volume required about 16 percent.

\begin{tabular}{|c|c|c|c|c|c|}
\hline ase & $\begin{array}{c}C s \\
C i / G a l \\
\end{array}$ & $\begin{array}{l}\text { TK-49 } \\
\text { Temp } \\
{ }^{\circ} \mathrm{C} \\
\end{array}$ & $\begin{array}{l}\text { TK- } 49 \\
\text { Sample } \\
\text { Cycle, Mon }\end{array}$ & $\begin{array}{l}\text { NRF Reactors } \\
\text { Required } \\
\text { No. Gals. }\end{array}$ & $\begin{array}{l}\text { Total } \\
\text { Volume } \\
\text { Percent } \\
\end{array}$ \\
\hline $\begin{array}{l}2 \\
8\end{array}$ & $\begin{array}{l}36 \\
36\end{array}$ & $\begin{array}{l}50 \\
40\end{array}$ & $\begin{array}{l}3 \\
3\end{array}$ & $\begin{array}{ll}2 & 95,000 \\
2 & 80,000\end{array}$ & $\begin{array}{r}100 \\
84\end{array}$ \\
\hline
\end{tabular}


TK-49 SAMPLE CYCLE:

Reducing the Tank 49 sample frequency from 3 months to 1 month will reduce the NRF volume about 21 percent.

\begin{tabular}{|c|c|c|c|c|c|}
\hline ase & $\begin{array}{c}C s \\
C i / G a l \\
\end{array}$ & $\begin{array}{l}\text { TK-49 } \\
\text { Temp } \\
{ }^{\circ} \mathrm{C} \\
\end{array}$ & $\begin{array}{l}\text { TK- } 49 \\
\text { Sample } \\
\text { Cycle, Mon }\end{array}$ & $\begin{array}{l}\text { NRF Reactors } \\
\text { Required } \\
\text { No. Gals. }\end{array}$ & $\begin{array}{l}\text { Total } \\
\text { Volume } \\
\text { Percent } \\
\end{array}$ \\
\hline $\begin{array}{l}2 \\
9\end{array}$ & $\begin{array}{l}36 \\
36\end{array}$ & $\begin{array}{l}50 \\
50\end{array}$ & $\begin{array}{l}3 \\
1\end{array}$ & $\begin{array}{ll}2 & 95,000 \\
2 & 75,000\end{array}$ & $\begin{array}{r}100 \\
79\end{array}$ \\
\hline
\end{tabular}

MINIMUM RECOMMENDED SIZE

Assuming that Tank 49 can be operated at $40^{\circ} \mathrm{C}$ and sampled once a month, and the NRF is designed for the average cesium expected in the first 5 years, then the recommended minimum size is 2-80,000 gallon reactors.

\begin{tabular}{|c|c|c|c|c|}
\hline ise & $\begin{array}{c}C s \\
C i / G a l \\
\end{array}$ & $\begin{array}{l}\text { TK-49 } \\
\text { Temp } \\
{ }^{\circ} \mathrm{C} \\
\end{array}$ & $\begin{array}{l}\text { TK-49 } \\
\text { Sample } \\
\text { Cycle, Mon }\end{array}$ & $\begin{array}{l}\text { NRF Reactor } \\
\text { Required } \\
\text { No. Gals. }\end{array}$ \\
\hline & 23 & 40 & 1 & 000 \\
\hline
\end{tabular}




\section{DISCUSSION}

This study was done to show the impact of various parameters on the size of Nitrite Radiolysis Facility (NRF). Final sizing will be done later.

Flowsheet: For this study, the high nitrite precipitate feed would be pumped from TK-49 to the NRF via the existing Low Point Pump Pit (LPPP). Existing Inter Area Transfer Lines would be used from TK-49 to the LPPP. New underground lines would be required from the LPPP to the NRF. Spare penetrations exist in the LPPP.

Low nitrite precipitate feed would be pumped from the NRF to the Precipitate Reactor Feed Tank (PRFT) via the LPPP. The existing line from LPPP to DWPF would be used. See Fig. I for Block Flow Diagram.

\section{TK-49 OPERATIONS}

Current TK-49 operating philosophy, as understood by the writer, were used in this study.

They are: -

- Minimum NO, concentration is $50 \%$ above minimum required as a corrosion inhibiter. Maximum $\mathrm{NO}_{2}$ concentration is a function of the $\mathrm{NO}_{2}$ destruction rate and the sample

$\therefore$ cycle. For the case where the minimum $\mathrm{NO}_{2}$ is $0.036 \mathrm{M}$ $\mathrm{NO}_{2}$, the sample cycle is every three months and the $\mathrm{NO}_{2}$ destruction rate is $0.01 \mathrm{M} \mathrm{NO} \mathrm{N}_{2}$; the maximum $\mathrm{NO}_{2}$ is $0.036+(3)$ $(0.01)=0.066 \mathrm{M}$.

- Batches of washed precipitate are transferred from TK-48 to TK-49 three times a year. TK-49 has about two years of production stored in it. The impact of different $\mathrm{NO}_{2}$ concentratiors in TK-48 and TK-49 was not considered in this study.

- The normal TK-49 sample cycle is three months, however, the affect of reducing the sample cycle to one month was studied.

0 The normal TK-49 operating temperature is $50^{\circ} \mathrm{C}$, however the affect of reducing the temperature to $40^{\circ} \mathrm{C}$ was studied. 
FEED RATE

The feed rate used in this study was $42,500 \mathrm{gals} / \mathrm{month}$, which is $75 \%$ of the instantaneous rate in the Basic Data Report. For final design, it may be prudent to design the NRF for $100 \%$ of the BDR rate. This would allow the DWPF to operate for extended periods between shut downs.

\section{TRANSFER CYCLES}

Low nitrite feed is transferred from the NRF to the PRFT every 43 hours. High nitrite feed is transferred from TK-49 to the NRF twice a month. The transfer cycle would be coordinated with the TK-49 nitrite addition cycle, i.e., the TK-49 to NRF transfer would be done just prior to the addition of $\mathrm{NaNO}_{2}$ to TK-49.

NRF OPERATION

The NRF reactors will initially be filled with feed from TK-49 at the minimum TK-49 nitrite concentration. When the nitrite level in the NRF reactors is less than $0.01 \mathrm{M}$, feed to the OWPF will start. After 15. days, the second reactor will be filled from the first reactor and the first reactor will be filled from TK-49. For each case studied, the reactors are sized to ensure the feed transferred to DWPF is always less than $0.01 \mathrm{M} \mathrm{NO}_{2}$.

The calculation for sizing the reactors and the resulting graphs were done using the EXCEL" spread sheet program.

The calculated values for each case are included in Appendix $A$ and the formulae used are included in Appendix B.

\section{SINGLE REACTOR VS MULTIPLE REACTORS}

Three cases were studied: 1,2 and 3 reactors. The results of these studies are shown as Cases 1,2 , and 3 . The nitrite concentration points for each period are the maximum at the start of each 15 day period. The total volume required for each case was essentially the same: 200,000 gallons for a single reactor; 190,000 gallons for two reactors; and 186,000 galloris for three reactors.

Increasing the number of reactors increases the costs, but also increases the operating flexibility and reliability. For the balance of this study, two reactors were useci. 


\section{CESIUM CONCENTRATION}

Cesium in the feed is the source of radioactivity which destroys the nitrite. The nitrite destruction rate is directly proportional to the cesium concentration. Since the nitrite destruction rate also affects the maximum nitrite concentration in Tank 49 , the size of the Nitrite Radiolysis Reactors required is not inversely proportional to cesium concentration, but close.

The maximum cesium concentration used in the study was $36 \mathrm{Ci} / \mathrm{Gal}$, the average of all salt waste in the waste tanks. This would require 2-95,000 gallon reactors. The minimum cesium concentration studied was $9.5 \mathrm{Ci} / \mathrm{Gal}$, which is $1 / 2$ the minimum concentration estimated for the salt to be processed in the first five years of operation. This would require 2-200,000 gallon reactors. See Cases 2, 4, 5, 6 and 7 . Conclusion: A realistic evaluation of cesium concentration is necessary to size the NRF reactors.

\section{TANK SAMPLE CYCLE}

If it is possible and practical to sample Tank 49 monthly as opposed to sampling every three months, the size of the reactors can be reduced about 20 percent. See Cases 2 and 9.

Conclusion: The feasibility of making this change should be investigated as soon as possible.

TANK 49. OPERATING TEMPERATURE

$$
\therefore
$$

Decreasing the Tank 49 operating temperature from $50^{\circ} \mathrm{C}$ to $40^{\circ} \mathrm{C}$ will reduce the required NRF volume about 14 percent. See Cases and 8 . Conclusion: The cost of adding chillers to the Tank 49 cool system needs to be compared with the cost of a larger Nitrite Radio Facility.

\section{HYPOTHETICAL DESIGN CASE}

This case is based on using the average cesium concentration expected in the first five years, operating Tank 49 at $40^{\circ} \mathrm{C}$ and sampling on a monthly basis. For this case, the NRF would regrite $2,80,000$ yallon reactors.

Conclusion: The potential for significantly reducint sing size of the million gallon stainless steel Nitrite Radiolysis ros: is great if a reasonable cesium concentration can be established and changing the operating philosophy of Tank 49 is possible.

$$
-6-
$$


PRELIMINARY CONCEPTUAL LAYOUT

A conceptual layout for a two reactor Nitrite Radiolysis Facility is shown in Figures 2 and 3 . It is based on a Pump Pit configuration. The reactors are horizontal cylindrical vessels, permanently installed in the cells. Only equipment subject to failure, such as pumps, agitators, temperature sensors and level sensors, would be designed for remote maintenance. This equipment would be removed using an overhead crane, as currently done in the Low Point Pump Pit. The structure housing the crane would be designed with smooth interior walls to improve housekeeping.

The overhead crane would be used to replace jumpers in the diversion box. The conceptual layout shows an equipment decon/maintenance cell which may or may not be required.

Sample cells, closed loop heat exchangers and piping penetrations to the cells would be located in the operating corridor.

The rationale used to develop the conceptual layout was:

- A-long narrow facility could be located northeast of the Low Point Pump Pit. Only the treated effluent line and several storm drains would need to be relocated.

- The existing spare penetrations from the LPPP precipitate cell

- are located in the east wall.

$\therefore$

- The reactors could be field fabricated during the same time frame as the cells and then lowered into the cell.

- The elevation of the NRF can be raised. The only criteria is that the high point of the transfer lines between the NRF and the LPPP be in the diversion box. This could minimize dewatering the site during construction.

- By using the existing LPPP precipitate pump tank to transfer feed from Waste Tank 49 to NRF and from NRF to OWPF, all precipitate transfer lines will continue to drain to LPPP. 
NITRITE RADIOLYSIS FACILITY

REACTOR SIZING STUDY

NITRITE CONCENTRATION VS TIME GRAPHS 


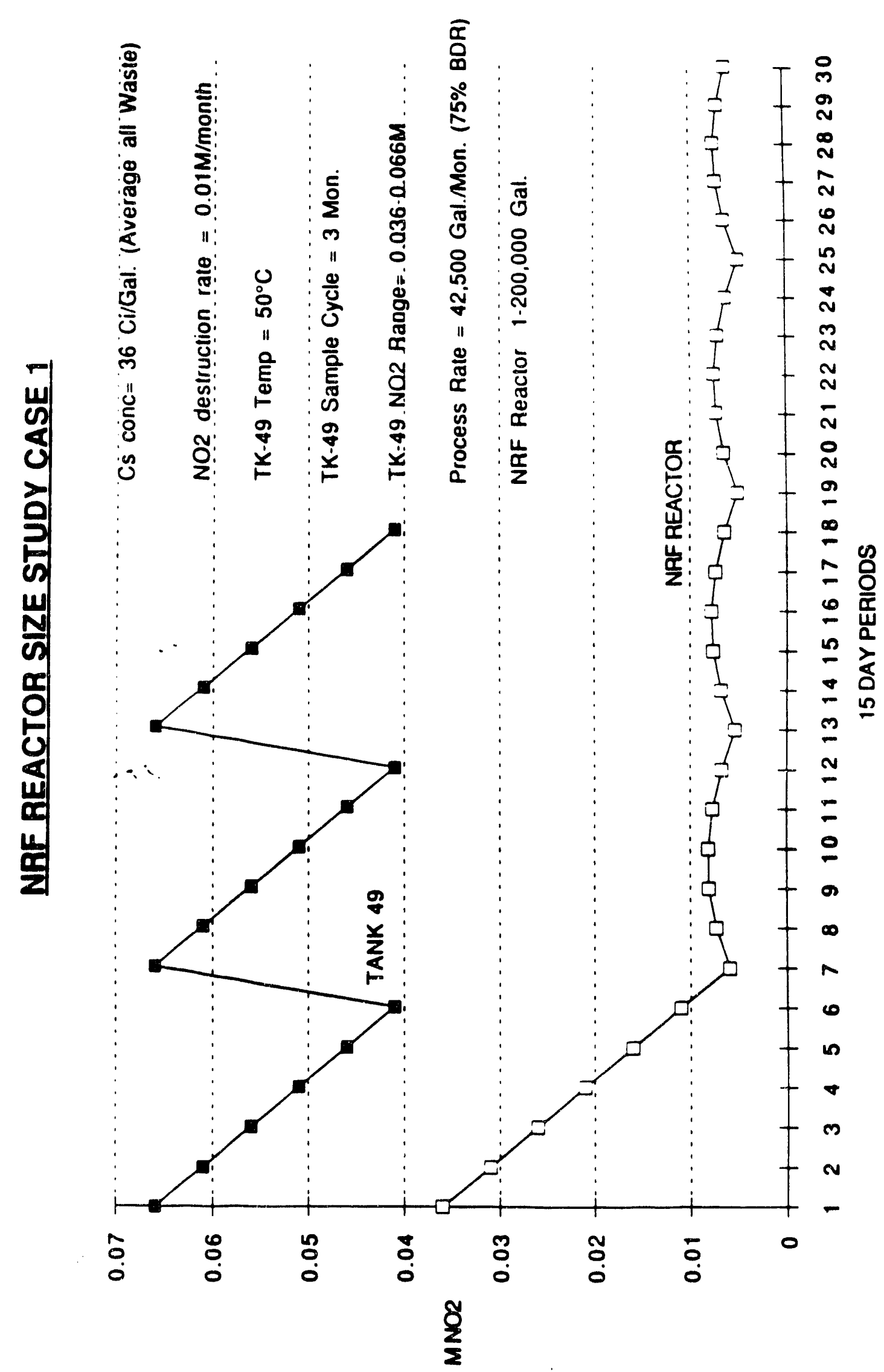


WSRC-TR-92-67, Rev $0 \quad$ P. G-15

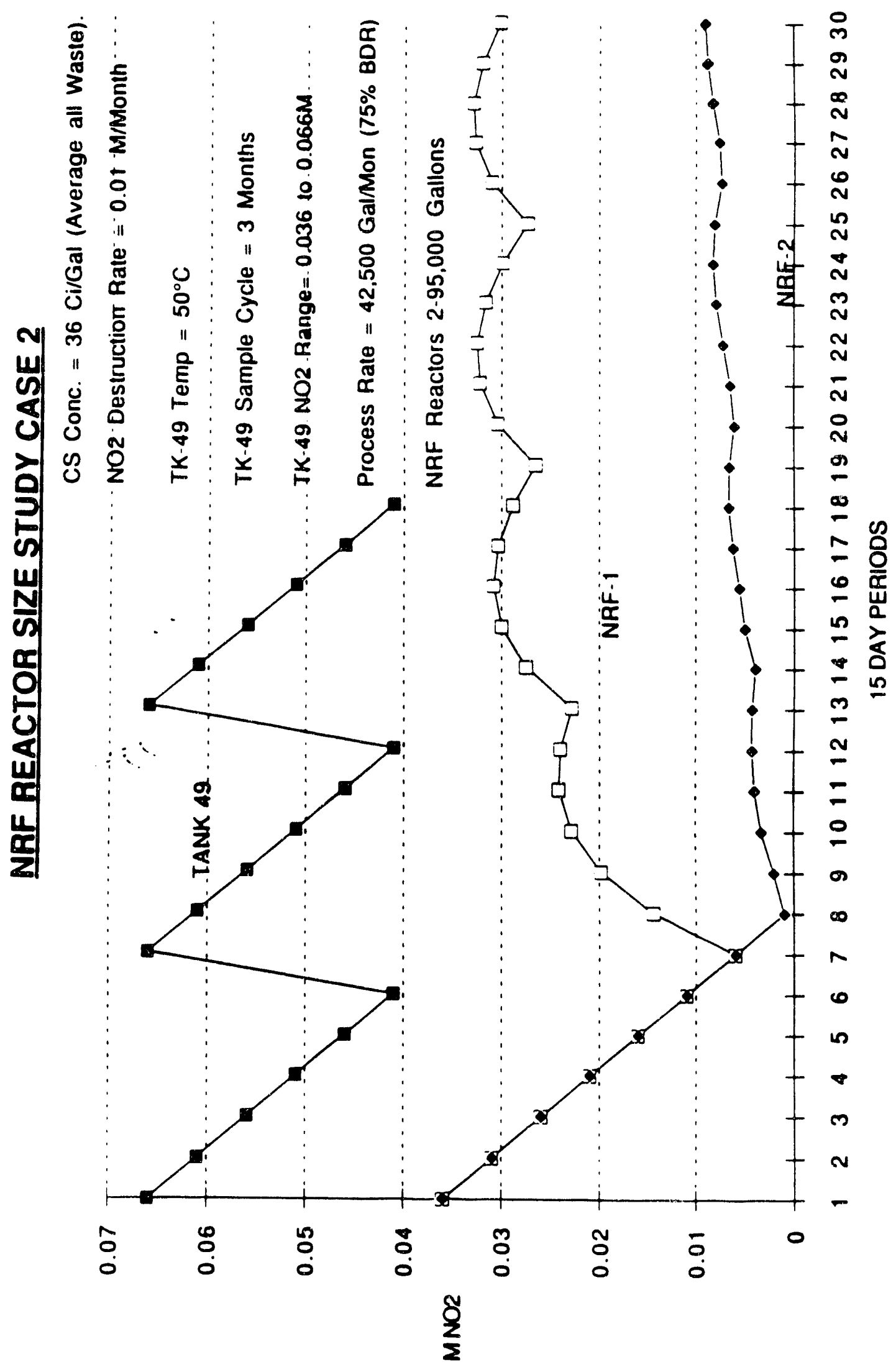




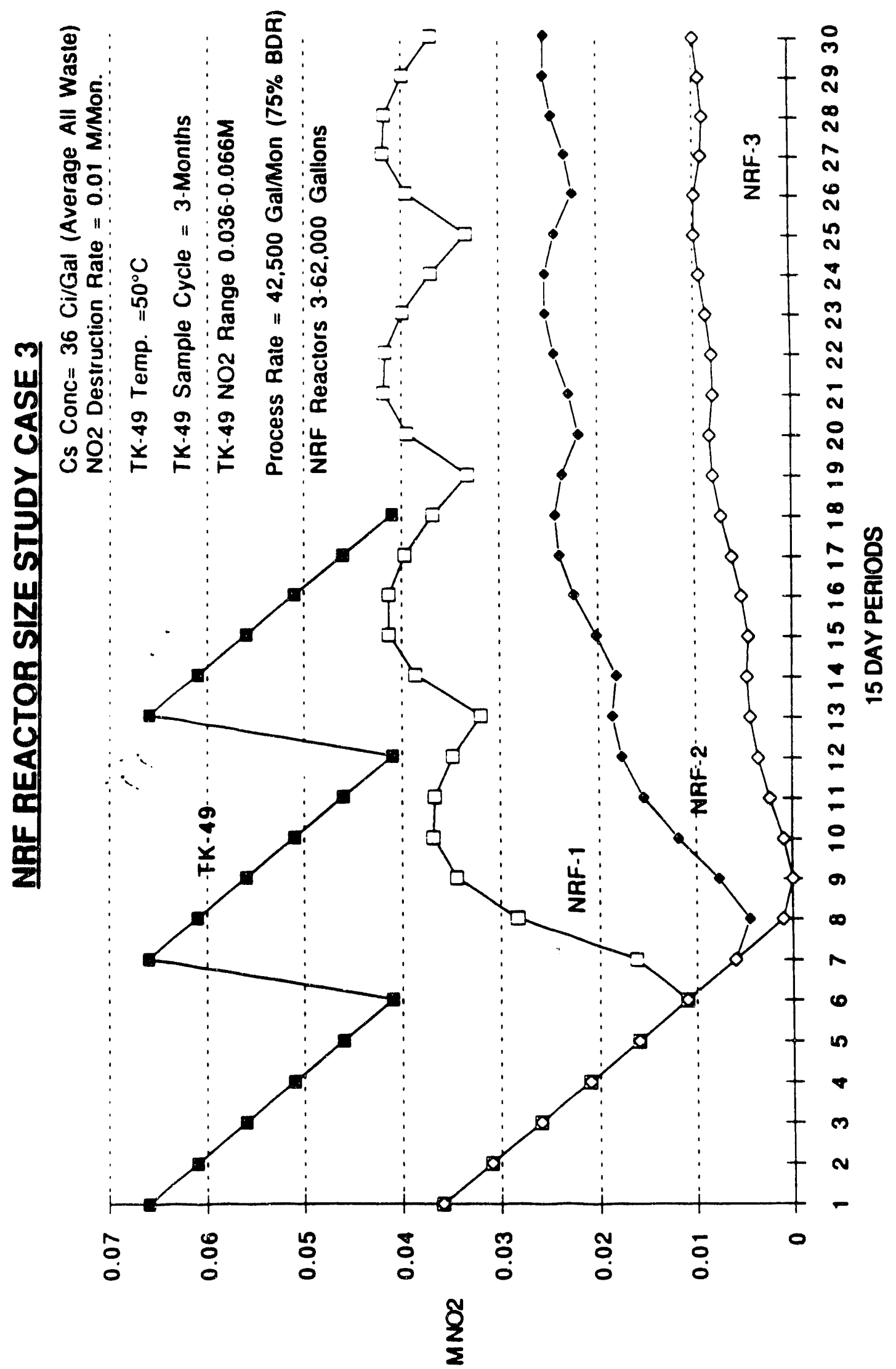

$\frac{N}{6}$
$\frac{1}{3}$
$\frac{3}{3}$ 


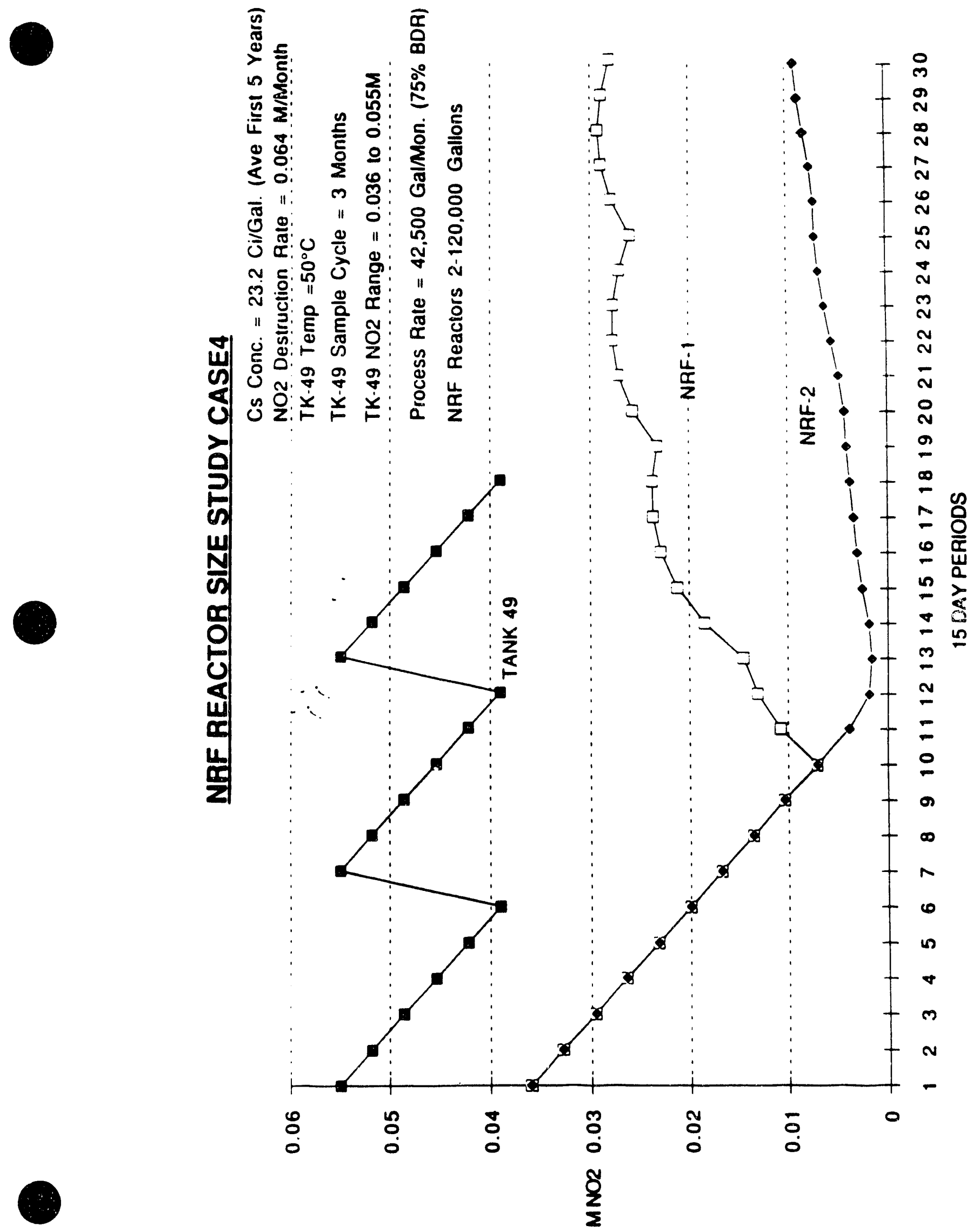




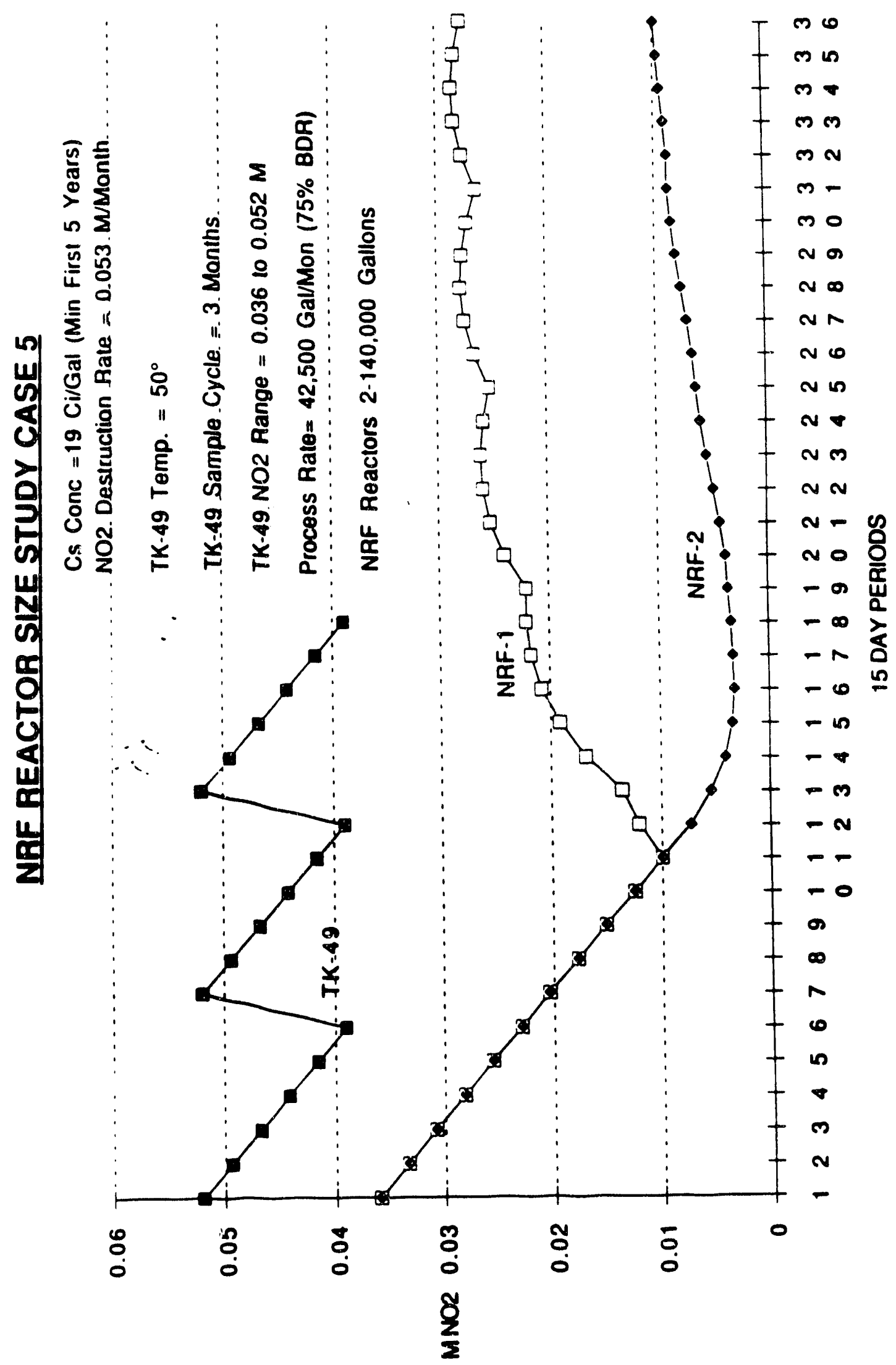




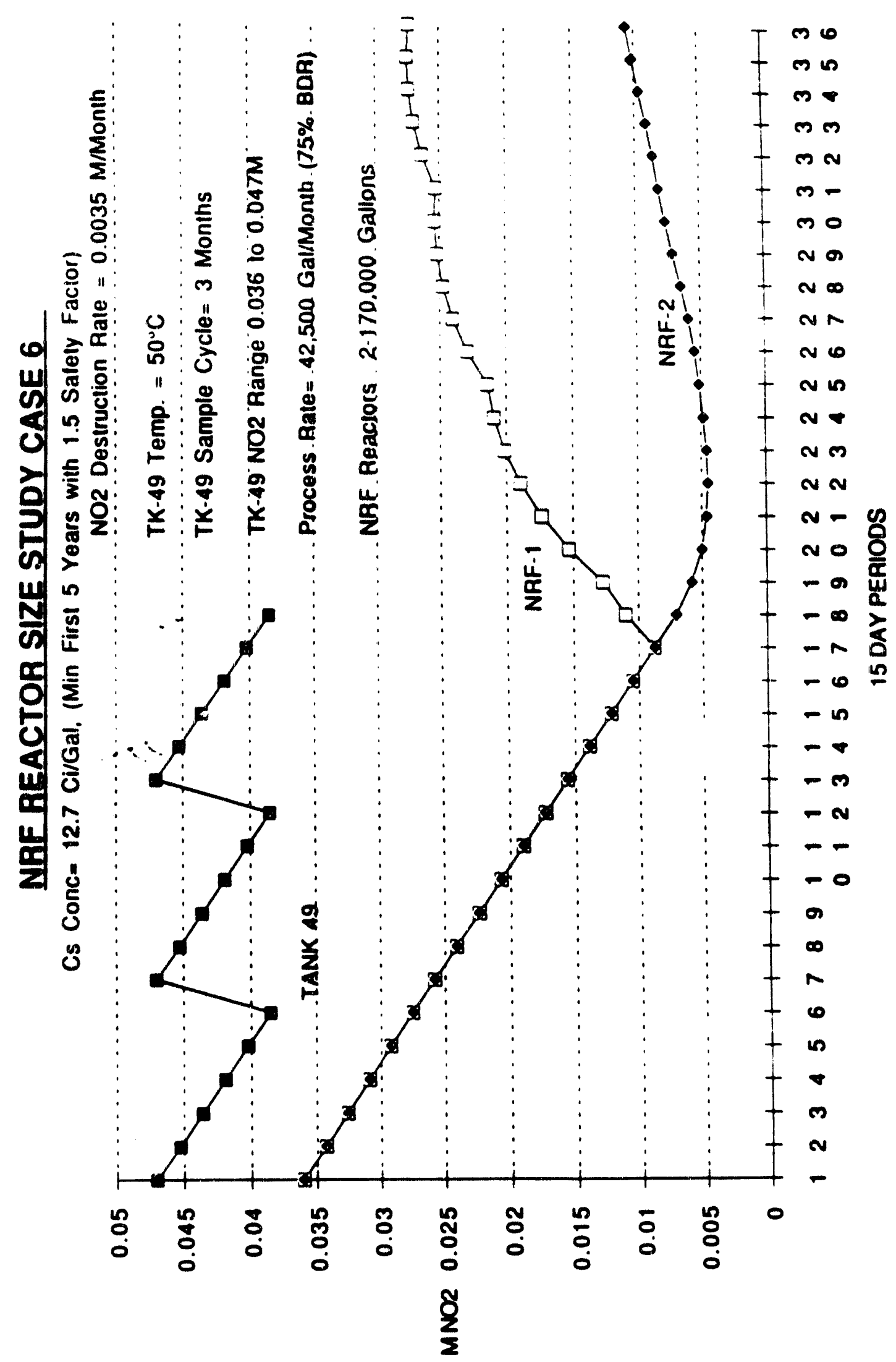




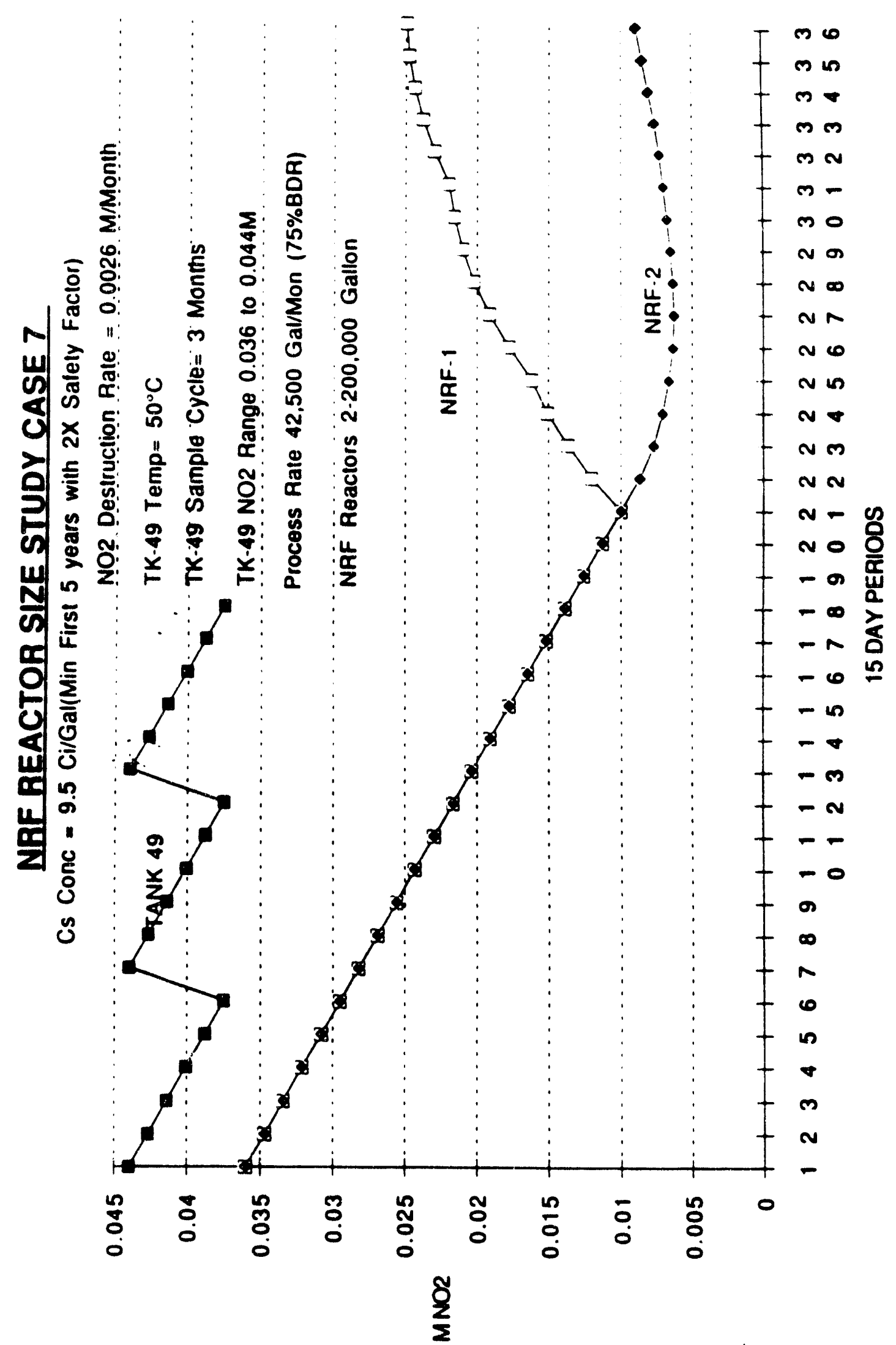




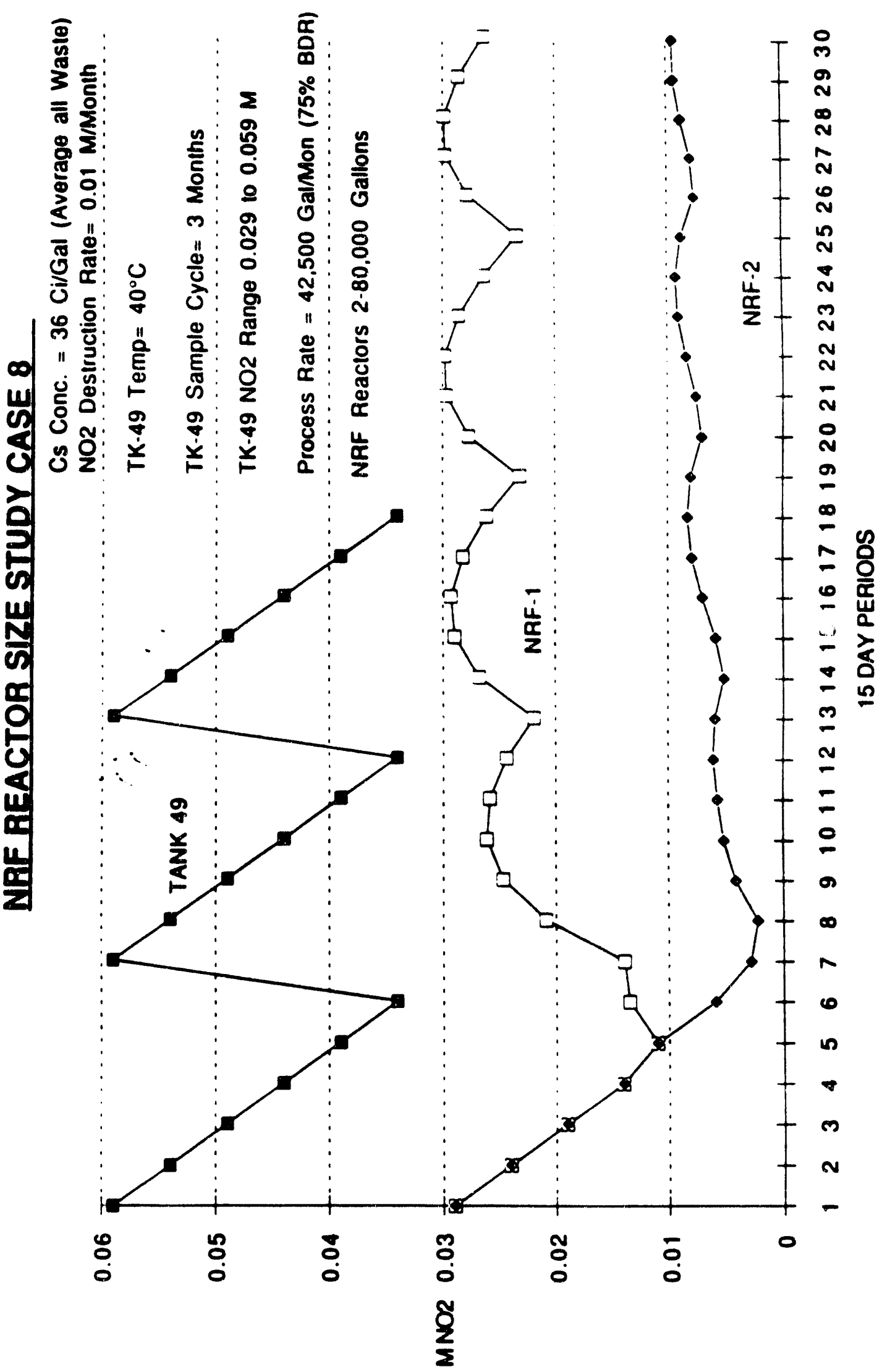




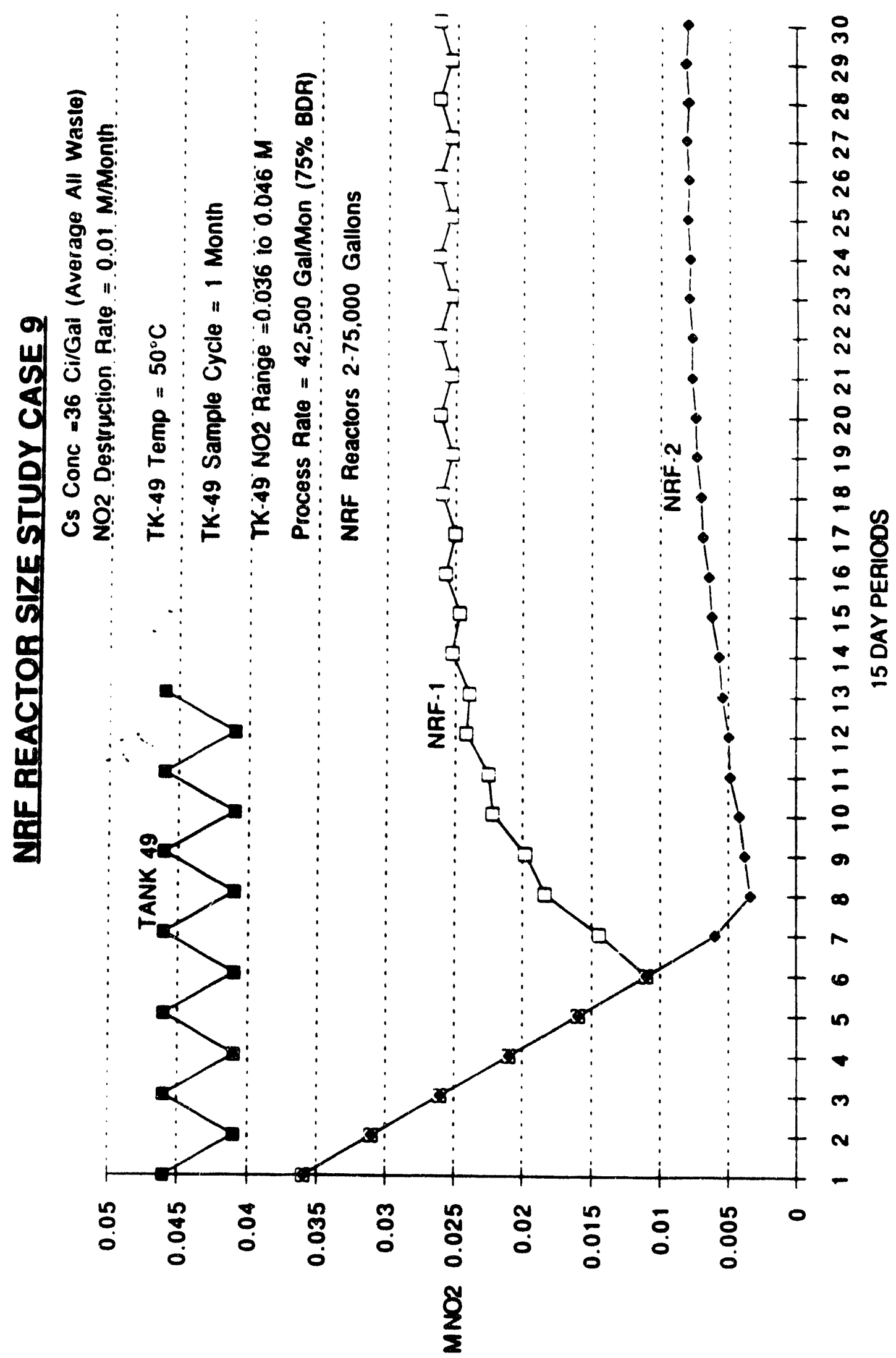




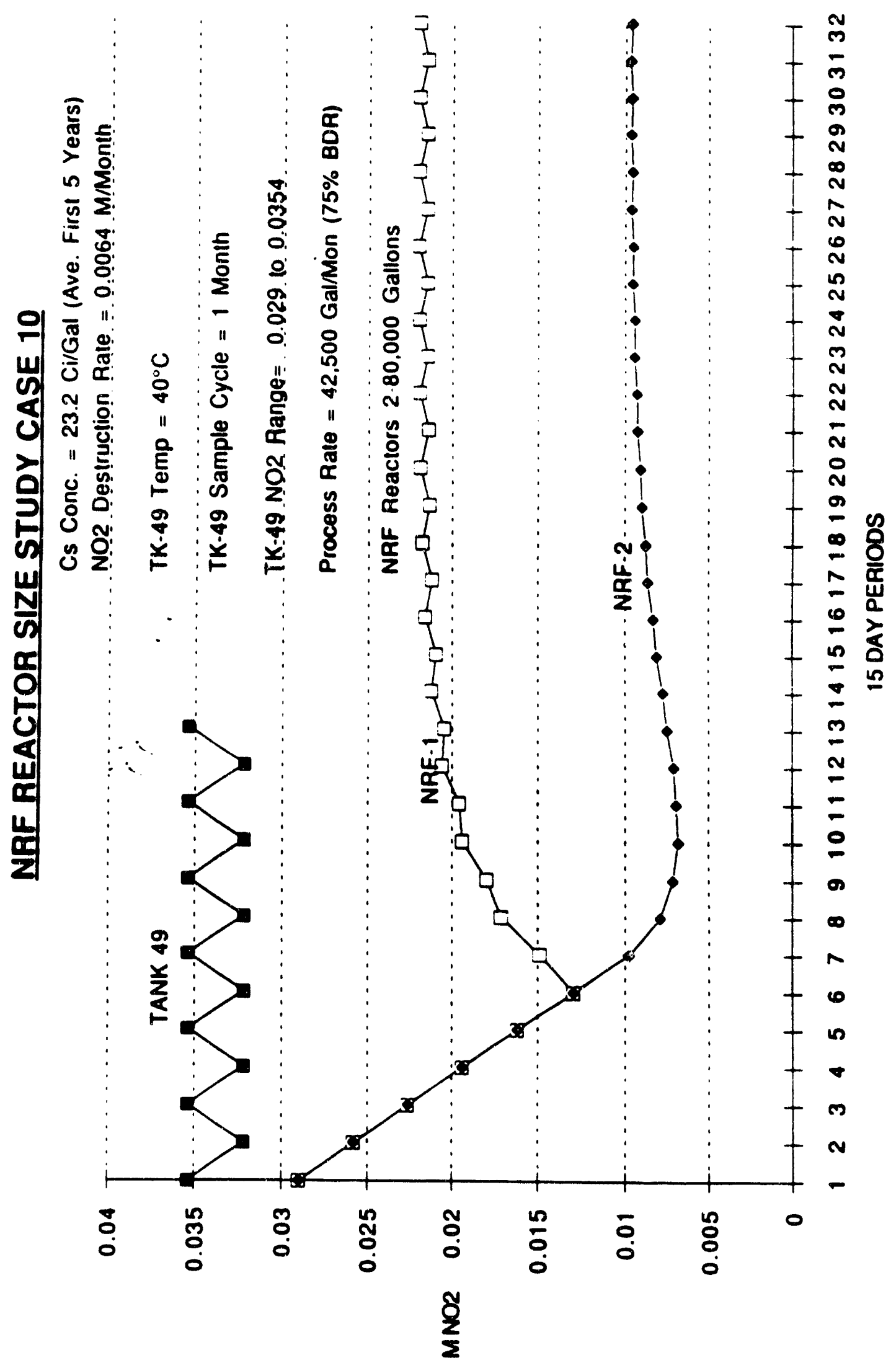




\title{
NITRITE RADIOLYSIS FACILITY \\ REACTOR SIZING STUDY
}

\author{
FIGURE 1 BLOCK FLOW DIAGRAM \\ FIGURE 2 CONCEPTUAL LAYOUT PLAN \\ FIGURE 3 CONCEPTUAL LAYOUT SECTION
}




\section{BLOCK FLOW DIAGRAM NITRITE RADIOLYSIS FACILITY}

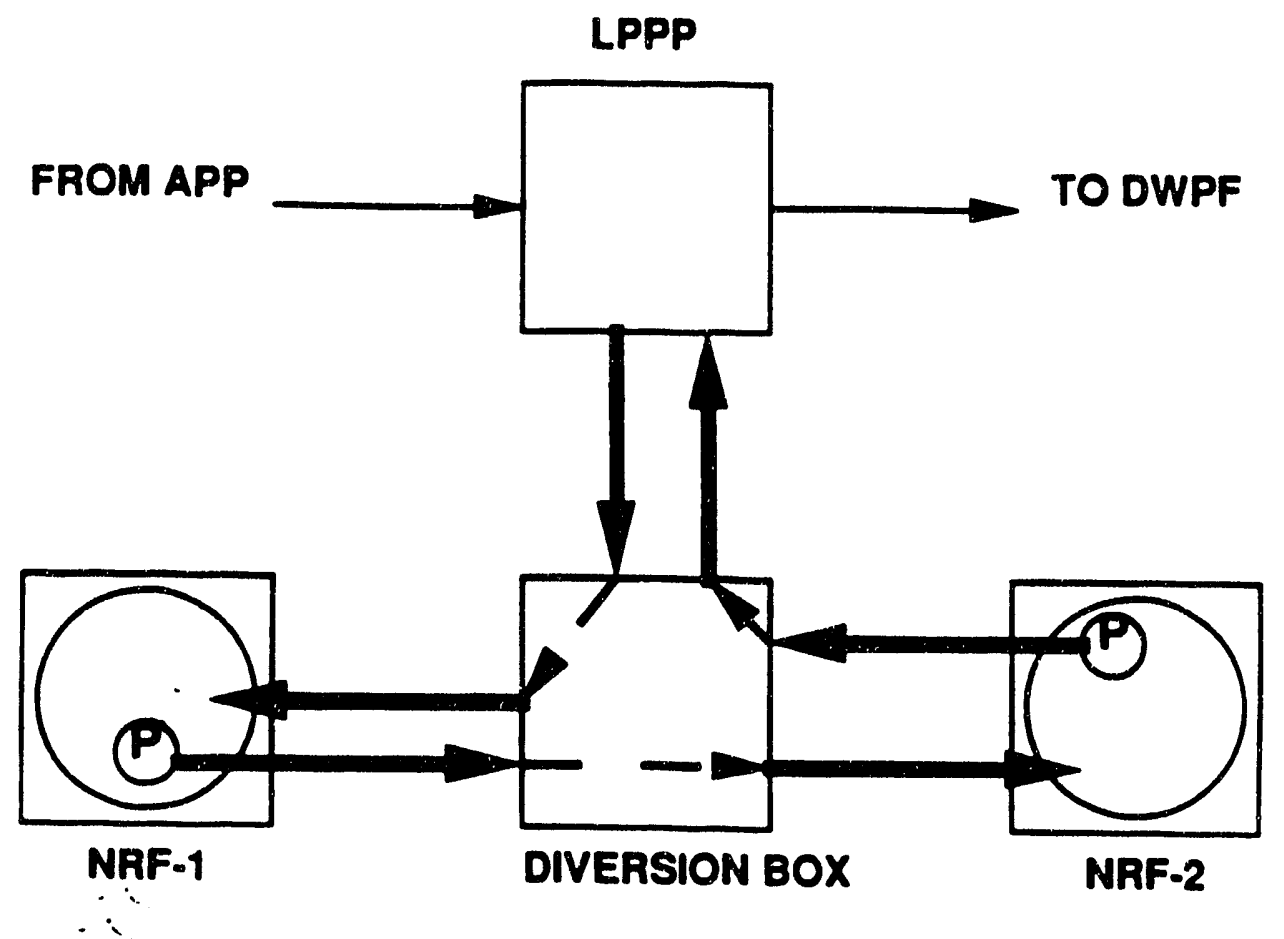

-PUMP LOW NITRITE FEED FROM NRF-2 TO DWPF AS REQUIRED VIA THE PRECIPITATE PUMP TANK IN THE LOW POINT PUMP PIT

-FILL NRF-2 FROM NRF-1 ON A BH-WEEKLY BASIS

-PUMP FEED FROM TANK 49 TO NRF-1 VIA THE PRECIPITATE PUMP TANK IN THE LOW POINT PUMP PIT ON A BI-WEEKLY BASIS.

-WILL REQUIRE INSTALLATION OF SECOND PUMP ON THE LPPP PRECIPITATE TANK

FIG. 1 
WSRC-TR-92-67, Rev 0

p. G-26

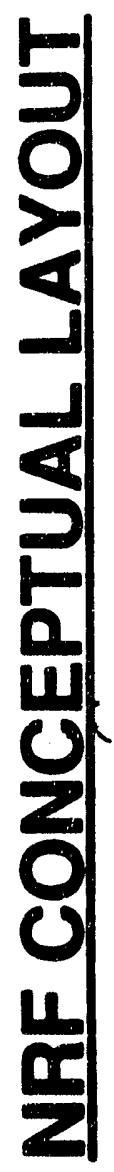

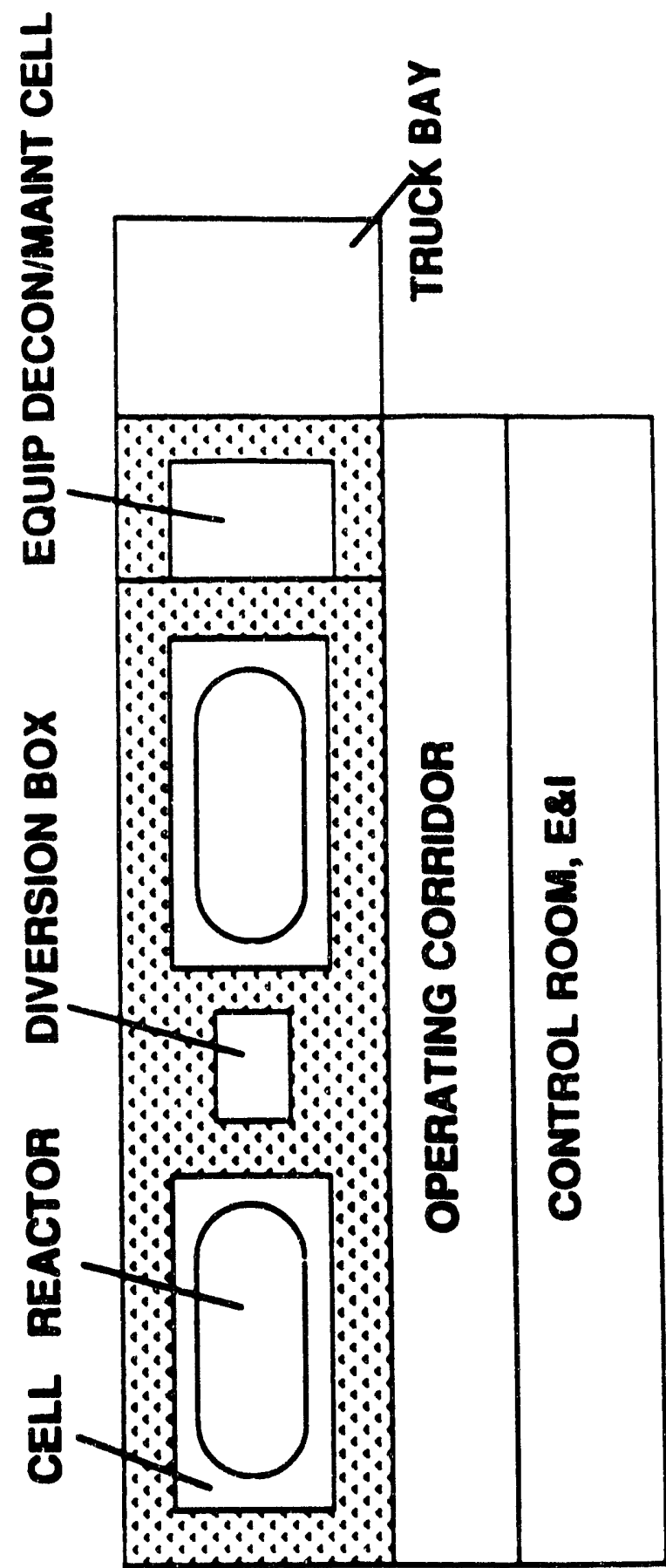

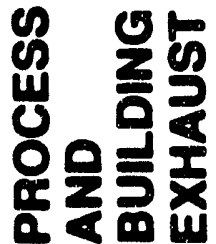




\section{NRF CONCEPTUAL SECTION}

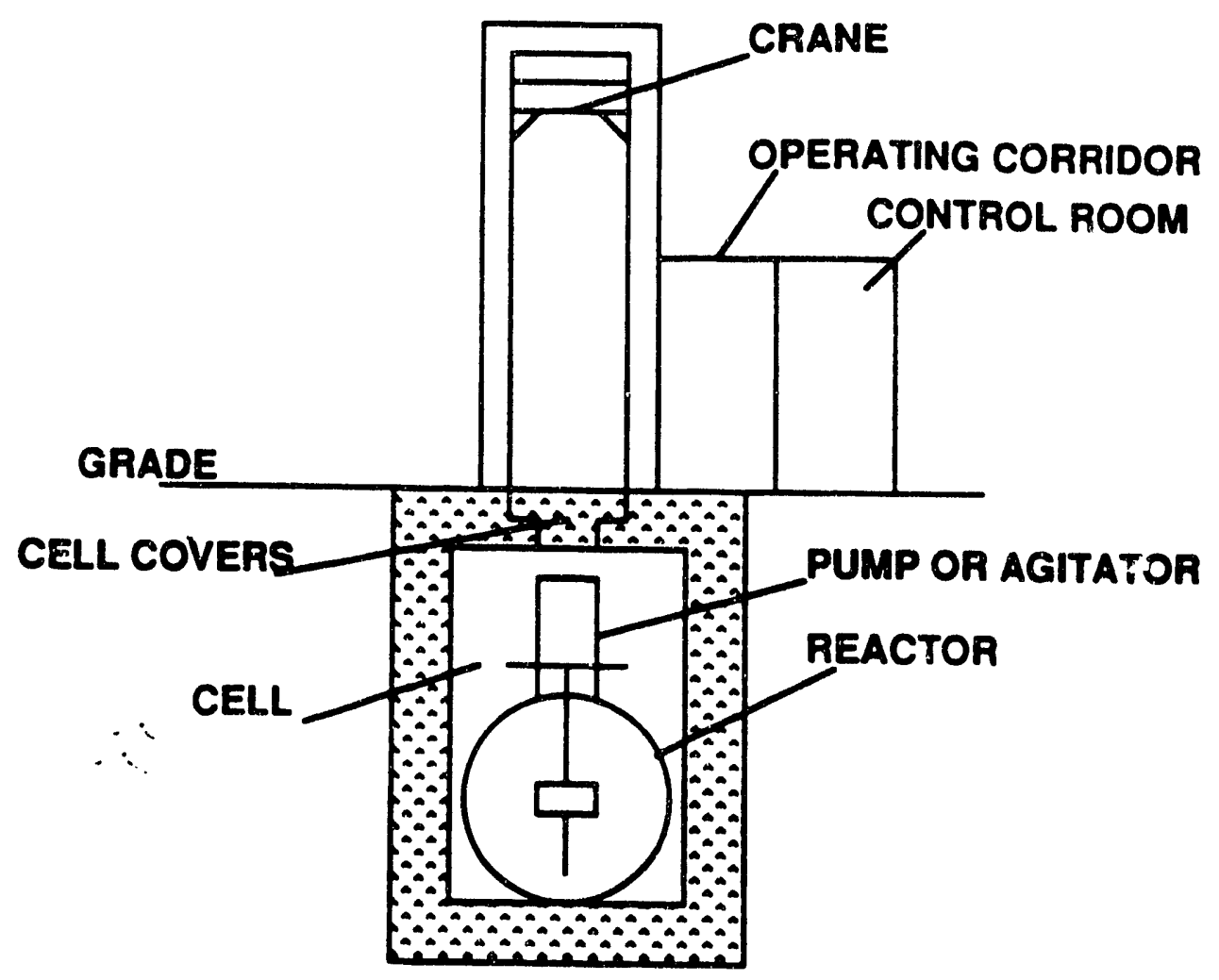

FIG. 3 
WSRC-TR-92-6', Rev $0 \quad$ p. G-28

NITRITE RADIOLYSIS FACILITY

REACTOR SIZING STUDY

\author{
APPENDIX A
}

CALCULATIONS

$\therefore \quad$ NITRITE CONCENTRATION VS TIME 


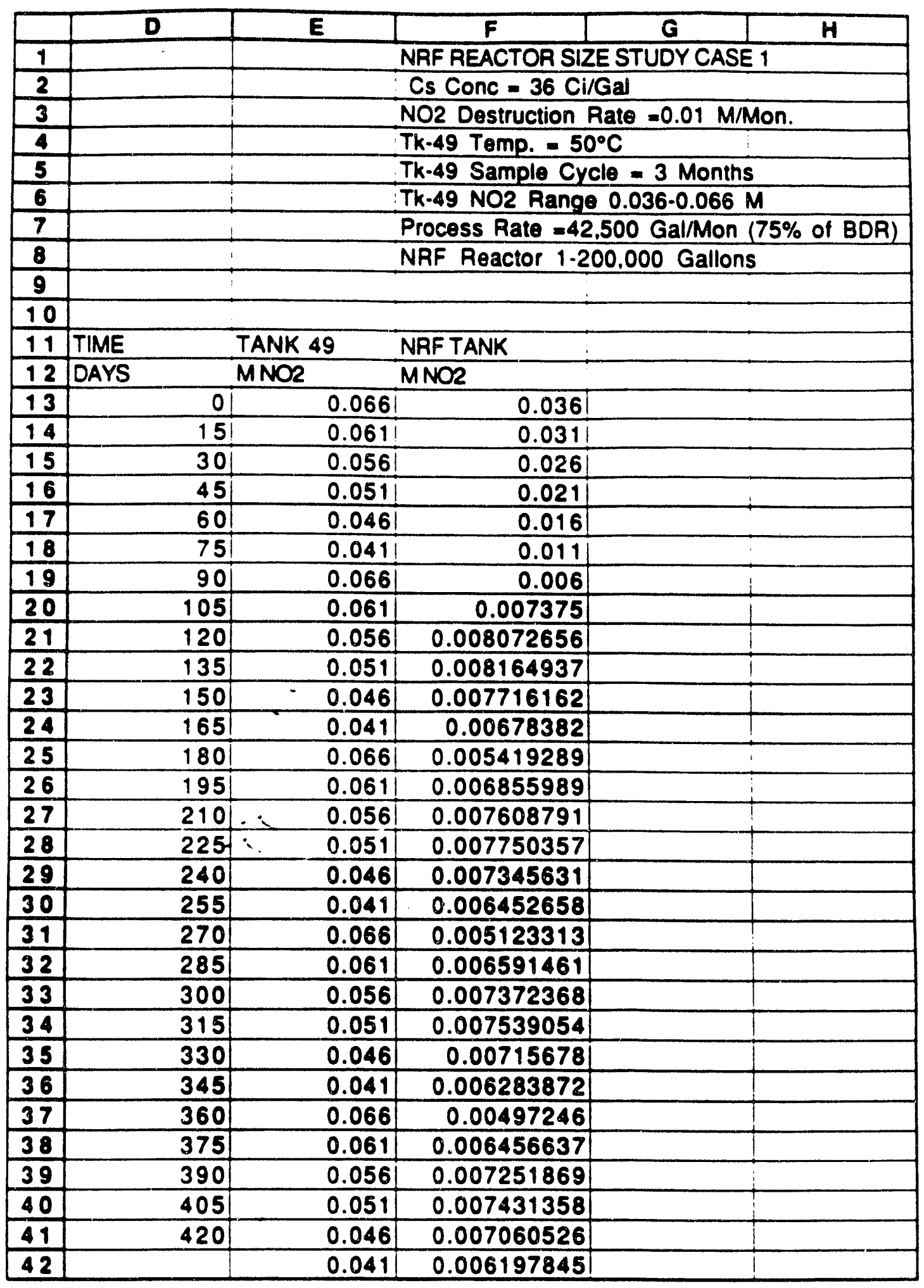




\begin{tabular}{|c|c|c|c|c|c|}
\hline & $\mathbf{E}$ & $\mathbf{F}$ & $\mathbf{G}$ & $\bar{H}$ & T \\
\hline 1 & 1 & & \multicolumn{3}{|c|}{ NRF REACTOR SIZE STUDY CASE 2} \\
\hline 2 & & & \multicolumn{3}{|c|}{ Cs $=36 \mathrm{CVGal}$ (Average all waste) } \\
\hline 3 & & & \multicolumn{3}{|c|}{ NO2 Destruction Rate $=0.01 \mathrm{M} / \mathrm{Mon}$. } \\
\hline 4 & & & \multicolumn{3}{|c|}{ TK-49 Temp. $=50^{\circ} \mathrm{C}$} \\
\hline 5 & & & \multicolumn{3}{|c|}{ TK-49 Sample Cycle - 3 Months } \\
\hline 6 & & & \multicolumn{3}{|c|}{ TK.49 NO2 Range $=0.036$ TO $0.066 \mathrm{M}$} \\
\hline 7 & & & \multicolumn{3}{|c|}{ Process Rate $=42,500$ Gal/Mon $(75 \%$ of BDR) } \\
\hline 8 & & & \multicolumn{2}{|c|}{ NRF Reactors $2-95,000$ gallons } & \\
\hline \multicolumn{6}{|c|}{ 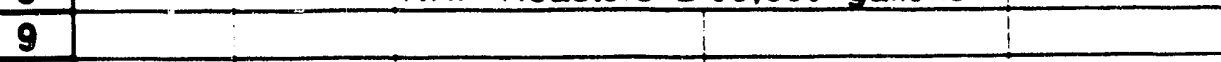 } \\
\hline \multicolumn{6}{|l|}{10} \\
\hline \multicolumn{6}{|l|}{11} \\
\hline \multicolumn{6}{|l|}{12} \\
\hline 13 & TIME & TK 49 & NRF-1 & NRF-2 & \\
\hline 14 & DAYS & MNO2 & MNO2 & MNO2 & \\
\hline 15 & 01 & 0.066 & 0.036 & 0.036 & \\
\hline 16 & 15 & 0.061 & 0.031 & 0.031 & \\
\hline 17 & 301 & 0.056 & 0.026 & 0.026 & \\
\hline 18 & $45 i$ & 0.051 & 0.021 & 0.021 & \\
\hline 19 & 601 & 0.046 & 0.016 & 0.0151 & \\
\hline 20 & 75 & 0.041 & 0.011 & $(1-1)$ & \\
\hline 21 & 90 & 0.066 & 0.006 & 0.086 & \\
\hline 22 & 105 & 0.061 & 0.014421053 & 0.001 & \\
\hline 23 & 120 & 0.056 & -0.019840028 & 0.002107341 & \\
\hline 24 & 135 & 0.0511 & 0.022928443 & 0.00331948 & \\
\hline 25 & 1501 & 0.046 & 0.024207607 & 0.00401031 & \\
\hline 26 & 165 & 0.0411 & 0.024082221 & 0.004296438 & \\
\hline 27 & 1801 & 0.066 & 0.022866461 & 0.004268392 & \\
\hline 28 & 195 & 0.061 & 0.027514753 & 0.003996445 & \\
\hline 29 & 210 & 0.056 & 0.030004874 & 0.005036195 & \\
\hline 30 & 225 & 0.051 & 0.030819573 & 0.005621294 & \\
\hline 31 & 240 & 0.046 & 0.030333616 & 0.006257751 & \\
\hline 32 & 255 & 0.041 & 0.028837939 & 0.006643142 & \\
\hline 33 & 270 & 0.066 & 0.0265584 & 0.006607768 & \\
\hline 34 & 285 & 0.061 & 0.030380863 & 0.006070409 & \\
\hline 35 & 300 & 0.056 & 0.03222988 & 0.006508274 & \\
\hline 36 & 315 & 0.051 & 0.032546881 & 0.007261791 & \\
\hline 37 & 330 & 0.046 & 0.031674552 & 0.007917666 & \\
\hline 38 & 345 & 0.041 & 0.029878929 & 0.008231707 & \\
\hline 39 & 360 & 0.066 & 0.027366537 & 0.008073848 & \\
\hline 40 & 3751 & 0.061 & 0.031008233 & 0.007389318 & \\
\hline 41 & 390 & 0.056 & 0.032716917 & 0.007672496 & \\
\hline 42 & 405 & 0.051 & 0.032924975 & 0.008274538 & \\
\hline 43 & 420 & 0.046 & 0.031968073 & 0.008788452 & \\
\hline 44 & 435 & 0.041 & 0.030106793 & 0.008973367 & \\
\hline
\end{tabular}


$\begin{array}{ll}\text { WSRC-TR-92-67, Rev } 0 & \text { P. G-31 }\end{array}$

\begin{tabular}{|c|c|c|c|c|c|}
\hline & $F$ & $\mathbf{G}$ & $\mathrm{H}$ & & $J$ \\
\hline 1 & & & \multicolumn{3}{|c|}{ INAF REACTOR SIZE STUC, OASE 3} \\
\hline 2 & & & \multirow{2}{*}{\multicolumn{3}{|c|}{\begin{tabular}{|l|} 
Cs Conc $=36$ Ci/Gal \\
NO2 Destruction Rate $=0.01$ MMMon.
\end{tabular}}} \\
\hline 3 & & & \\
\hline 4 & & & & & \\
\hline 5 & & & \\
\hline 6 & 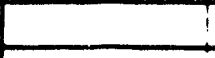 & & \multirow{2}{*}{\multicolumn{3}{|c|}{$\begin{array}{l}\text { Th-49 NO2 Range } 0.036 \cdot 0.066 \mathrm{M} \\
\text { Process Rate }=42.500 \mathrm{Gal} / \mathrm{Mon}(75 \% \text { of BDR) }\end{array}$}} \\
\hline 7 & & & & & \\
\hline 8 & & & \multicolumn{3}{|c|}{ NAF Reaciors 3.62.000 Gallons } \\
\hline 9 & & & & & \\
\hline 10 & TIME & TANK 49 & INRF-1 & NRF-2 & NRF-3 \\
\hline 11 & DAYS & MNO2 & MNOR & MNOR & MNO2 \\
\hline 12 & 0 & 0.066 & 0.0361 & 0.036 & 0.036 \\
\hline 13 & 15 & 0.061 & 0.031 & 0.031 & 0.031 \\
\hline 14 & 301 & 0.056 & 0.026 & 0.026 & 0.026 \\
\hline 15 & 451 & 0.051 & 0.021 & 0.021 & 0.021 \\
\hline 16 & 601 & 0.046 & 0.016 & 0.016 & 0.016 \\
\hline 17 & 75 & 0.041 & 0.011 & 0.011 & 0.011 \\
\hline 18 & 901 & 0.066 & 0.0162822581 & 0.006 & 0.006 \\
\hline 19 & 105 & 0.061 & 0.028322613 & 0.004524161 & 0.001 \\
\hline 20 & 120 & 0.056 & 0.034522524 & 0.007680889 & 0 \\
\hline 2 & 135 & 0.051 & 0.036883756 & 0.011880643 & 0.000918853 \\
\hline 22 & 150 & 0.046 & 0.036721985 & 0.015450258 & 0.002358285 \\
\hline 23 & 165 & 0.041 & 0.03490195 & 0.017740971 & 0.003581742 \\
\hline 24 & 1801 & 0.066 & 0.031992007 & 0.018622758 & 0.004366865 \\
\hline 25 & 1951 & 0.061 & 0.038647972 & 0.01820496 & 0.00466909 \\
\hline 26 & 2101 & 0.056 & 0.04130895 & 0.020211638 & 0.004525894 \\
\hline 27 & 2251 & 0.051 & 0.041344189 & 0.022442571 & 0.005213666 \\
\hline 28 & 2401 & 0.046 & 0.03965364 & 0.023920948 & 0.006118734 \\
\hline 29 & 255 & 0.041 & 0.036828804 & 0.024313201 & 0.0072203 \\
\hline 30 & 270 & 0.066 & 0.033258448 & 0.023602823 & 0.008078754 \\
\hline 31 & 285 & 0.061 & 0.039480351 & 0.021012211 & 0.008399503 \\
\hline 32 & 300 & 0.056 & 0.041856037 & 0.022933549 & 0.008030875 \\
\hline 33 & 3151 & 0.051 & 0.041703766 & 0.024419079 & 0.008138646 \\
\hline 34 & 3301 & 0.046 & 0.039889975 & 0.025343266 & 0.008718633 \\
\hline 35 & 345 & 0.041 & 0.036984137 & 0.025329033 & 0.009416592 \\
\hline 36 & 360 & 0.066 & 0.033360542 & 0.024323726 & 0.009870453 \\
\hline 37 & 375 & 0.061 & 0.039547453 & 0.022421022 & 0.009824196 \\
\hline 38 & 390 & 0.056 & 0.04190014 & 0.023290968 & 0.009141656 \\
\hline 39 & 4051 & 0.051 & 0.041732754 & 0.024669112 & 0.008991219 \\
\hline 40 & 4201 & 0.046 & 0.039909028 & 0.025517537 & 0.00936469 \\
\hline 41 & & 0.041 & 0.036996659 & 0.025450105 & 0.009900948 \\
\hline
\end{tabular}




\begin{tabular}{|c|c|c|c|c|c|}
\hline & $\bar{E}$ & $\mathbf{F}$ & $\mathbf{G}$ & $\bar{H}$ & I \\
\hline 1 & \multicolumn{5}{|c|}{ NAF REACTOR SIZE STUDY CASE 41} \\
\hline 2 & & & \multicolumn{3}{|l|}{ Cs $-23.2 \mathrm{Ci} / \mathrm{Gal}$} \\
\hline 3 & & & \multicolumn{3}{|c|}{ NO2 Destruction Rate $=0.0064$ M/Mon. } \\
\hline 4 & & - & \multicolumn{3}{|c|}{ TK-49 Temp. $=50^{\circ} \mathrm{C}$} \\
\hline 5 & & 1 & \multicolumn{3}{|c|}{ TK-49 Sample Cycle - 3 Months } \\
\hline 6 & & 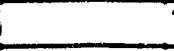 & \multicolumn{3}{|c|}{ TK-49 NO2 Range $=0.036$ TO $0.055 \mathrm{M}$} \\
\hline 7 & & & \multicolumn{3}{|c|}{ Process Rate $=42.500 \mathrm{Gal} / \mathrm{Mon}(75 \%$ of BDR) } \\
\hline 8 & \multicolumn{5}{|c|}{ NRF Reactors 2-120,000 gallons } \\
\hline \multicolumn{6}{|l|}{9} \\
\hline 10 & TIME & TK 49 & NRF-1 & $\overline{R F-2}$ & \\
\hline 11 & DAYS & \multicolumn{4}{|c|}{ MNO2 (FIMNO2 (FORMULAM NO2 (FORMULA) } \\
\hline 12 & 0 & 0.055 & 0.0361 & $0.036 !$ & \\
\hline 13 & 15 & 0.0518 & 0.0328 & 0.03281 & \\
\hline 14 & 30 & 0.04861 & 0.02961 & 0.02961 & \\
\hline 15 & 45 & 0.04541 & 0.02641 & $0.0264 i$ & \\
\hline 16 & 60 & 0.0422 & 0.02321 & 0.02321 & \\
\hline 17 & 75 & 0.039 & 0.021 & 0.021 & \\
\hline 18 & 90 & 0.055 & 0.01681 & 0.0168 & \\
\hline 19 & 105 & 0.0518 & 0.01361 & 0.0136 & \\
\hline 20 & 120 & 0.0486 & 0.0104 & 0.0104 & \\
\hline 21 & 135 & 0.0454 & 0.0072 & 0.0072 & \\
\hline 22 & 150 & 0.0422 & 0.010764583 & 0.004 & \\
\hline 23 & 165 & 0.039 & 0.013131272 & 0.001997895 & \\
\hline 24 & 180 & 0.055 & 0.014512192 & 0.001758663 & \\
\hline 25 & 195 & $0.0518 !$ & 0.018481908 & 0.002003201 & \\
\hline 26 & 210 & 0.0486 & 0.021181987 & 0.002706171 & \\
\hline 27 & 225 & 0.0454 & 0.02283726 & 0.00318431 & \\
\hline 28 & 240 & 0.0422 & 0.023632745 & 0.003477431 & \\
\hline 29 & 255 & 0.039 & 0.023720697 & 0.003846602 & \\
\hline 30 & 270 & 0.055 & 0.023226407 & 0.004165973 & \\
\hline 31 & 285 & 0.0518 & 0.02565298 & 0.004341258 & \\
\hline 32 & 300 & 0.0486 & 0.027083182 & 0.004915209 & \\
\hline 33 & 315 & 0.0454 & 0.027693452 & 0.005640787 & \\
\hline 34 & 330 & 0.0422 & 0.027829986 & 0.006345947 & \\
\hline 35 & 345 & 0.039 & 0.03700927 & 0.006914818 & \\
\hline 36 & 360 & 0.055 & 0.025932628 & 0.007273211 & \\
\hline 37 & 375 & 0.0518 & 0.027879975 & 0.007377483 & \\
\hline 38 & 390 & 0.0486 & 0.028915813 & 0.007808132 & \\
\hline 39 & 405 & 0.0454 & 0.029201555 & 0.008345951 & \\
\hline 40 & 420 & 0.0422 & 0.028870029 & 0.008839131 & \\
\hline 41 & 435 & 0.039 & 0.028030545 & 0.009186269 & \\
\hline
\end{tabular}




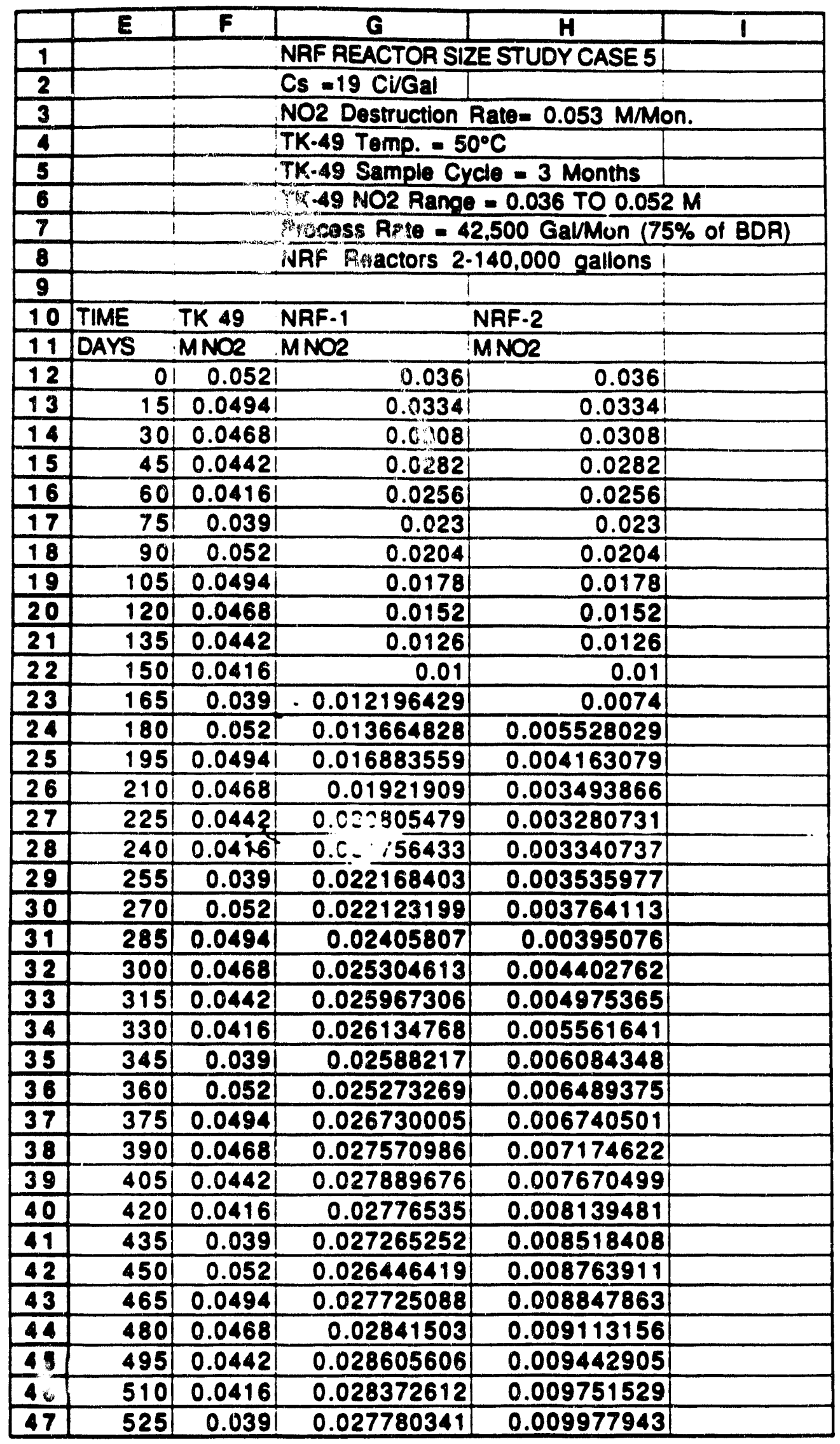




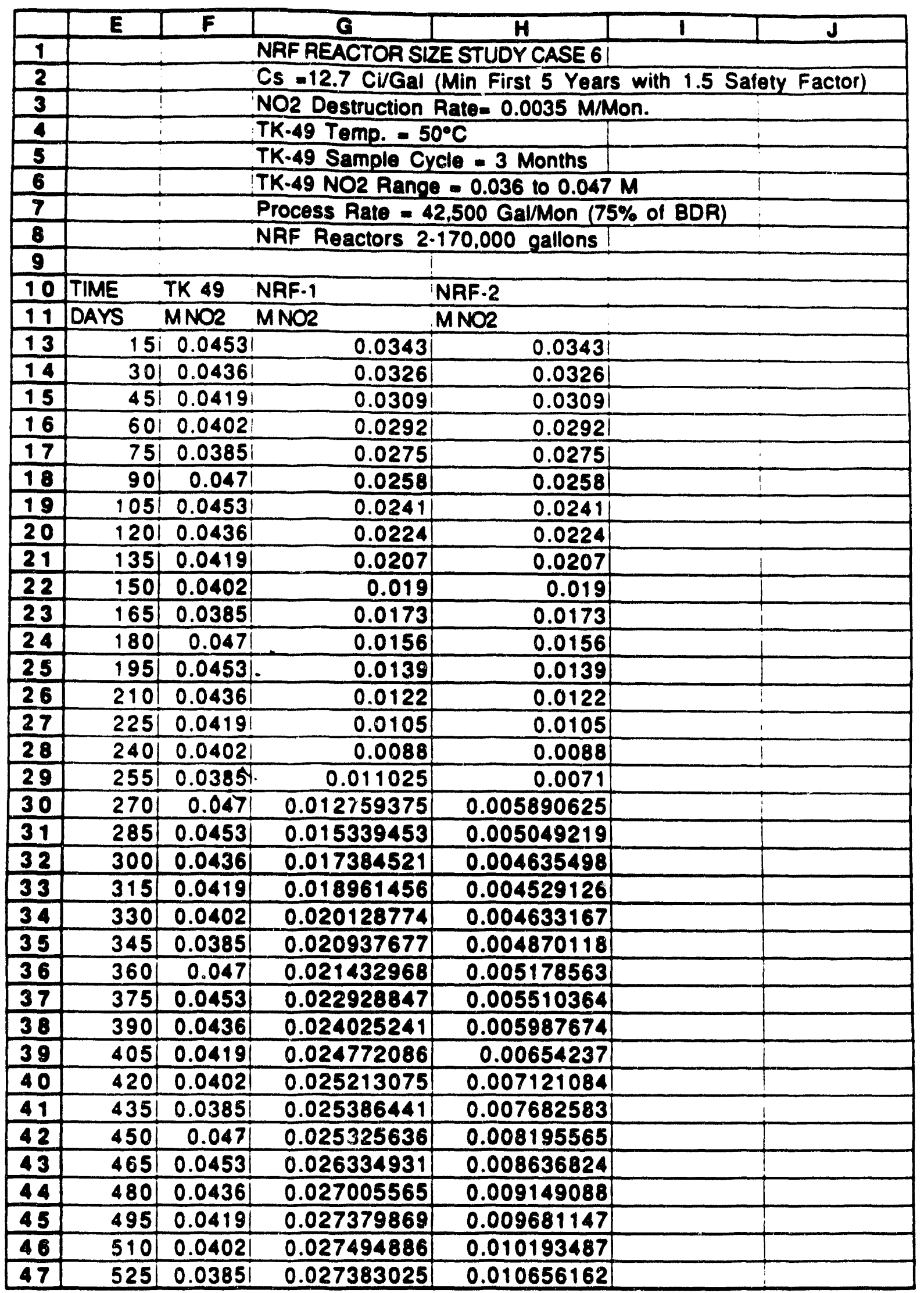




\begin{tabular}{|c|c|c|c|c|c|c|}
\hline & $E$ & $F$ & $\mathbf{G}$ & $\mathrm{H}$ & 1 & $J$ \\
\hline 1 & & & NRF REACTOR SIZ & STUDY CASE 7 & & \\
\hline 2 & & & $\mathrm{Cs}=9.5 \mathrm{Ci} / \mathrm{Gal} \mathrm{A}$ & in First 5 Years & with 2X Safety & y Factor) \\
\hline 3 & & & NO2 Destruction & ate $=0.026 \mathrm{M} / \mathrm{Mo}$ & & \\
\hline 4 & & & TK-49 Temp. $=50$ & & & \\
\hline 5 & & & TK-49 Sample Cy & $10=3$ Months & & \\
\hline 6 & & & TK.49 NO2 Range & $=0.036$ TO 0.044 & $M$ & \\
\hline 7 & & & Process Rate $=4$ & 500 GalMMon $(75$ & $5 \%$ of $B D R$ ) & \\
\hline 8 & & & NRF Reactors 2 & 00.000 gallons & & \\
\hline 9 & & & & 1 & $\ldots$ & \\
\hline 10 & TIME & TK 49 & NRF-1 & RF-2 & & \\
\hline 11 & DAYS & MNO2 & MNO2 & INO2 & & \\
\hline 12 & 0 & 0.044 & 0.0361 & 0.036 & & \\
\hline 13 & 15 & 0.0427 & 0.0347 & 0.0347 & & \\
\hline 14 & 30 & 0.0414 & 0.0334 & 0.0334 & & \\
\hline 15 & 45 & 0.0401 & 0.0321 & 0.0321 & & \\
\hline 16 & 60 & 0.0388 & 0.03081 & 0.0308 & & \\
\hline 17 & 751 & 0.0375 & 0.0295 & 0.0295 & & \\
\hline 18 & 901 & 0.044 & 0.0282 & 0.0282 & & \\
\hline 19 & 105 & 0.0427 & 0.0269 & 0.0269 & & \\
\hline 20 & 1201 & 0.0414 & 0.0256 & 0.0256 & & 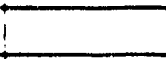 \\
\hline 21 & 135 & 0.0401 & $0.02+3$ & 0.0243 & & \\
\hline 22 & 1501 & 0.0388 & 0.023 & 0.023 & & \\
\hline 23 & 1651 & 0.0375 & 0.0217 & 0.0217 & & \\
\hline 24 & 1801 & 0.044 & 0.0204 & 0.0204 & & \\
\hline 25 & 195 & 0.0427 & 0.0191 & 0.0191 & & \\
\hline 26 & 210 & 0.0414 & 0.0178 & 0.0178 & & \\
\hline 27 & 2251 & 0.0401 & 0.0165 & 0.0165 & & \\
\hline 28 & 240 & 0.0388 & 0.0152 & 0.0152 & & \\
\hline 29 & 255 & 0.0375 & 0.0139 & 0.0139 & & \\
\hline 30 & 2701 & 0.044 & 0.0126 & 0.0126 & & \\
\hline 31 & 285 & 0.0427 & 0.0113 & 0.0113 & & \\
\hline 32 & 300 & 0.0414 & 0.01 & 0.01 & & \\
\hline 33 & 315 & 0.0401 & 0.01203625 & 0.0087 & & \\
\hline 34 & 3301 & 0.0388 & 0.013718023 & 0.007754477 & & \\
\hline 35 & $345 !$ & 0.0375 & 0.015082983 & 0.007088103 & & \\
\hline 36 & 360 & 0.044 & 0.016164791 & 0.006637559 & & \\
\hline 37 & 375 & 0.0427 & 0.017822282 & 0.006349828 & & \\
\hline 38 & 390 & 0.0414 & 0.01916554 & 0.006268776 & & \\
\hline 39 & $405 i$ & 0.0401 & 0.020227951 & 0.006339057 & & \\
\hline 40 & 4201 & 0.0388 & 0.021039356 & 0.006514752 & & \\
\hline 41 & 435 & 0.0375 & 0.021626425 & 0.006757991 & & \\
\hline 42 & 4501 & 0.044 & 0.022012992 & 0.007037762 & & $!$ \\
\hline 43 & 465 & 0.0427 & 0.023049112 & 0.007328881 & & \\
\hline 44 & 480 & 0.0414 & 0.023837019 & 0.007699155 & & \\
\hline 45 & 495 & 0.0401 & 0.024403085 & 0.008113803 & & \\
\hline 46 & 510 & 0.0388 & 0.024770883 & 0.008544539 & & \\
\hline 47 & 525 & 0.0375 & 0.024961476 & 0.008968588 & & \\
\hline
\end{tabular}




\begin{tabular}{|c|c|c|c|c|c|}
\hline & $\bar{E}$ & $\mathbf{F}$ & G & H & 1 \\
\hline 1 & & & \multicolumn{3}{|c|}{ NRF REACTOR SIZE STUDY CASE 8} \\
\hline 2 & & & \multirow{2}{*}{\multicolumn{3}{|c|}{$\begin{array}{l}\text { Cs }=36 \mathrm{Ci} / \mathrm{Gal} \text { (Average all waste) } \\
\text { NO2 Destruction Rate }=0.01 \mathrm{M} \text { Monon }\end{array}$}} \\
\hline 3 & & & \multirow{2}{*}{\multicolumn{3}{|c|}{ TK. 49 Testruction Rate $=0.01$ M/Mon. }} \\
\hline 4 & & & & & \\
\hline 5 & & & \multicolumn{3}{|c|}{ TK-49 Sample Cycle $=3$ Months } \\
\hline 6 & & & \multicolumn{3}{|c|}{ TK-49 NO2 Range $=0.029$ to $0.059 \mathrm{M}$} \\
\hline 7 & & & \multicolumn{3}{|c|}{ Process Rate $=42,500 \mathrm{Gal} / \mathrm{Mon}(75 \%$ of $\mathrm{BDR})$} \\
\hline 8 & & & \multicolumn{3}{|c|}{ NAF Reactors $2 \cdot 80.000$ gallons } \\
\hline \multicolumn{6}{|l|}{9} \\
\hline \multicolumn{6}{|l|}{10} \\
\hline \multicolumn{6}{|l|}{11} \\
\hline 12 & TIME & TANK49 & NRF-1 & RF-2 & \\
\hline 13 & DAYS & MNO2 & MNO2 & $\mathrm{NO2}$ & \\
\hline 14 & 0 & 0.059 & 0.029 & $0.029 !$ & \\
\hline 15 & 15 & 0.0541 & 0.0241 & 0.0241 & \\
\hline 16 & 30 & 0.049 & 0.019 & 0.019 & \\
\hline 17 & 45 & 0.044 & 0.014 & 0.014 & \\
\hline 18 & 60 & 0.039 & 0.0111 & 0.0111 & \\
\hline 19 & 75 & 0.034 & 0.0134375 & 0.006 & \\
\hline 20 & 90 & 0.059 & 0.013899414 & 0.002975586 & \\
\hline 21 & 105 & 0.054 & 0.020879257 & 0.002363907 & \\
\hline 22 & 120 & 0.049 & 0.024676955 & 0.004217928 & \\
\hline 23 & 135 & 0.044 & 0.026137763 & 0.005226691 & \\
\hline 24 & 150 & 0.039 & 0.02588242 & 0.005781195 & \\
\hline 25 & 165 & 0.034 & 0.024366777 & 0.006120583 & \\
\hline 26 & 180 & 0.059 & 0.021925602 & 0.005967228 & \\
\hline 27 & 195 & 0.054 & 0.026773489 & 0.005206171 & \\
\hline 28 & 210 & $\therefore 0.049$ & 0.029005531 & 0.00593499 & \\
\hline 29 & 225 & 0.044 & 0.029316562 & 0.007063102 & \\
\hline 30 & 240 & 0.039 & 0.02821685 & 0.007974178 & \\
\hline 31 & 255 & 0.034 & 0.026081124 & 0.008351137 & \\
\hline 32 & 270 & 0.059 & 0.023184576 & 0.008060665 & \\
\hline 33 & 285 & 0.054 & 0.027698048 & 0.007077954 & \\
\hline 34 & 300 & 0.049 & 0.029684504 & 0.007555166 & \\
\hline 35 & 315 & 0.044 & 0.029815182 & 0.008433272 & \\
\hline 36 & 330 & 0.039 & 0.028583025 & 0.009112842 & \\
\hline 37 & 345 & 0.034 & 0.026350034 & 0.009284609 & \\
\hline 38 & 360 & 0.059 & 0.023382056 & 0.008817612 & \\
\hline 39 & 375 & 0.054 & 0.027843072 & 0.007686293 & \\
\hline 40 & 390 & 0.049 & 0.029791006 & 0.008040437 & \\
\hline 41 & 405 & 0.044 & 0.029893395 & 0.008817932 & \\
\hline 42 & 420 & 0.039 & 0.028640462 & 0.009416102 & \\
\hline 43 & & 0.034 & 0.026392214 & 0.009522573 & \\
\hline
\end{tabular}




\begin{tabular}{|c|c|c|c|c|c|}
\hline & $\underline{E}$ & $F$ & $\mathbf{G}$ & H & 1 \\
\hline 1 & & & \multicolumn{3}{|c|}{ NRF REACTOR SIZE STUDY CASE 91} \\
\hline 2 & & & \multicolumn{3}{|c|}{ Cs -36 Ci/Gal (Average all waste) } \\
\hline 3 & & & \multicolumn{3}{|c|}{ NO2 Destruction Rate $=0.01 \mathrm{M} / \mathrm{Mon}$. } \\
\hline 4 & & & \multicolumn{3}{|c|}{ TK-49 Tomp. $-50^{\circ} \mathrm{C}$} \\
\hline $\mathbf{5}$ & & & \multirow{2}{*}{\multicolumn{3}{|c|}{ TK-49 Sample Cycle $=1$ Month }} \\
\hline 6 & 1 & 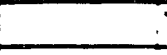 & & $=0.036$ TO 0.046 & $6 \mathrm{M}$ \\
\hline 7 & & & \multicolumn{3}{|c|}{ Process Rate $=42,500 \mathrm{Gal} / \mathrm{Mon}(75 \%$ of $\mathrm{BDR})$} \\
\hline 8 & & & \multirow{2}{*}{\multicolumn{3}{|c|}{ NRF Reactors 2.75 .000 gallons }} \\
\hline \multicolumn{4}{|c|}{ 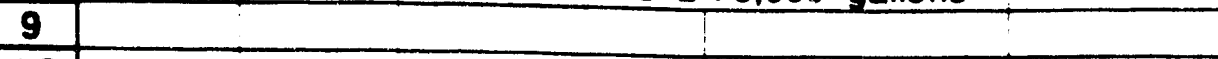 } & & \\
\hline \multicolumn{6}{|l|}{10} \\
\hline \multicolumn{6}{|l|}{11} \\
\hline 12 & TIME & TK 49 & NRF-1 & NRF.2 & \\
\hline 13 & DAYS & MNO2 & MNO2 & MNO2 & \\
\hline 14 & $0 !$ & $0.046 !$ & 0.036 & 0.0361 & \\
\hline 15 & $15 !$ & 0.041 & 0.031 & 0.0311 & \\
\hline 16 & 301 & $0.046 !$ & 0.026 & 0.026 & \\
\hline 17 & 45 & 0.0411 & 0.021 & 0.021 & \\
\hline 18 & 60 & $0.046 i$ & 0.016 & 0.016 & \\
\hline 19 & 751 & 0.0411 & 0.011 & 0.011 & \\
\hline 20 & 901 & 0.046 & 0.0145 & 0.006 & \\
\hline 21 & 105 & 0.041 & 0.018425 & 0.003408333 & \\
\hline 22 & 120 & 0.0461 & 0.01982125 & 0.00380375 & \\
\hline 23 & 135 & 0.0411 & 0.022238563 & 0.004199354 & \\
\hline 24 & 150 & 0.0461 & 0.022554303 & 0.004884259 & \\
\hline 25 & 165 & 0.0411 & 0.024197251 & 0.004973719 & \\
\hline 26 & $180 !$ & $0.046 !$ & 0.02395803 & 0.005439221 & \\
\hline 27 & 1951 & 0.0411 & 0.025203255 & 0.005686217 & \\
\hline 28 & 2101 & 0.0464 & 0.024678999 & 0.006216044 & \\
\hline 29 & 225 & 0.047 & 0.025719949 & 0.006447215 & \\
\hline 30 & 240 & 0.046 & 0.025049297 & 0.006907823 & \\
\hline 31 & 255 & 0.041 & 0.02598533 & 0.007047907 & \\
\hline 32 & 270 & 0.046 & 0.225239486 & 0.00741351 & \\
\hline 33 & 285 & 0.041 & 0.026121632 & 0.007464203 & \\
\hline 34 & 300 & 0.046 & 0.025337169 & 0.007750475 & \\
\hline 35 & 315 & 0.041 & 0.026191638 & 0.007733372 & \\
\hline 36 & 330 & 0.046 & 0.025387341 & 0.007963214 & \\
\hline 37 & 345 & 0.041 & 0.026227594 & 0.00790005 & \\
\hline 38 & 360 & 0.046 & 0.025413109 & 0.008092854 & \\
\hline 39 & 375 & 0.041 & 0.026246062 & 0.00800026 & \\
\hline 40 & 390 & 0.046 & 0.025426344 & 0.008169903 & \\
\hline 41 & 405 & 0.041 & 0.026255547 & 0.008059228 & \\
\hline 42 & 420 & 0.046 & 0.025433142 & 0.008214852 & \\
\hline 43 & 435 & 0.0411 & 0.026260418 & 0.008093367 & \\
\hline
\end{tabular}




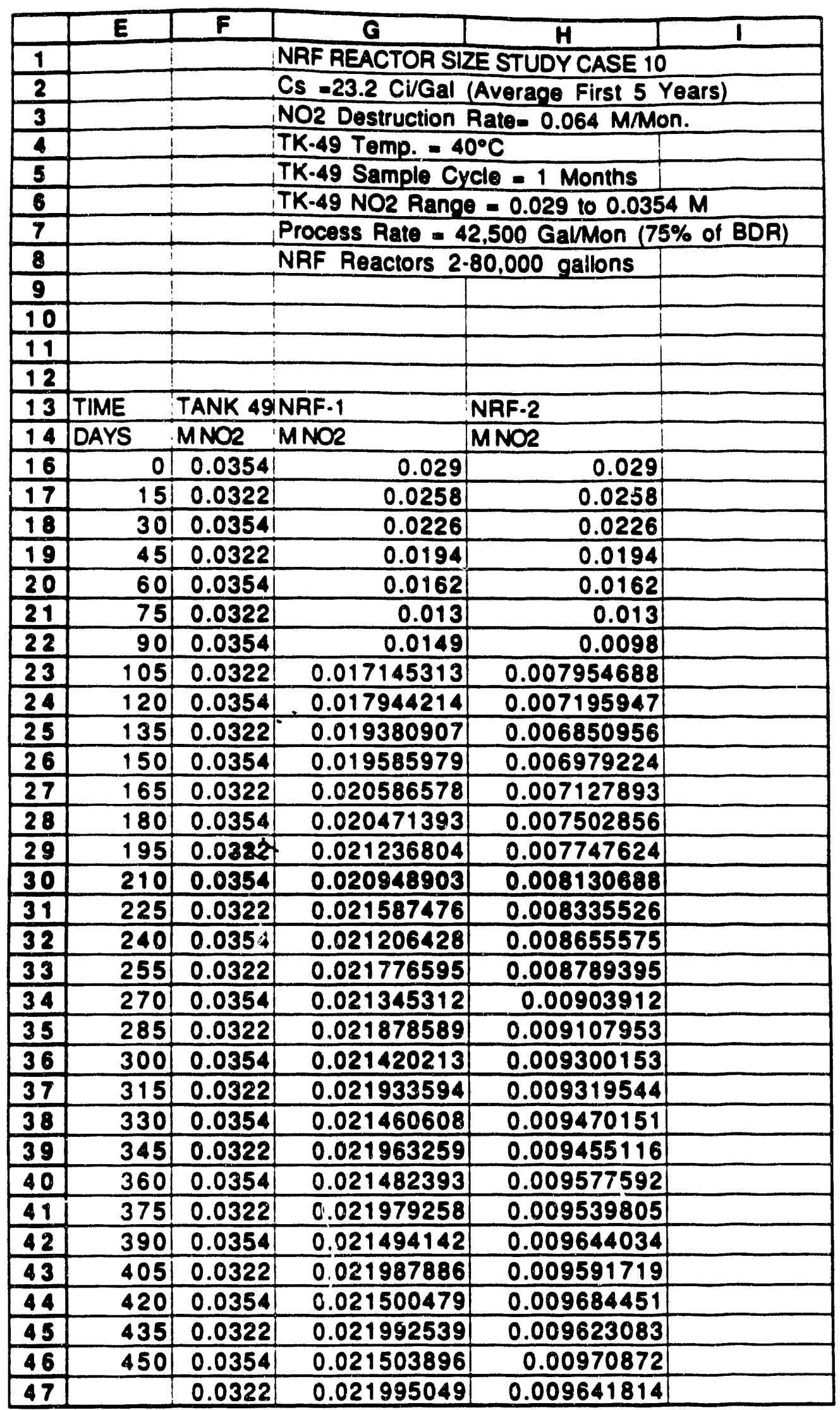




\section{NITRITE RADIOLYSIS FACILITY REACTOR SIZING STUDY}

APRENDIX B

FORMULAE USED IN CALCULATIONS

$\because$ 


\begin{tabular}{|c|c|c|c|}
\hline & $\mathbf{D}$ & $\bar{E}$ & $\mathbf{F}$ \\
\hline 1 & & & NRF REACTOR SIZE STUDY CASE 1 \\
\hline 2 & & & Cs Conc $=36 \mathrm{Ci} / \mathrm{Gal}$ \\
\hline 3 & & & NO2 Destruction Rate $=0.01 \mathrm{M} / \mathrm{Mon}$. \\
\hline 4 & & & Tk-49 Temp. $=50^{\circ} \mathrm{C}$ \\
\hline 5 & & & Tk-49 Sample Cycle $=3$ Months \\
\hline 6 & & & TK-49 NO2 Range 0.036-0.066 M \\
\hline 7 & & & Process Rate $=42.500 \mathrm{Gal} / \mathrm{Mon}(75 \%$ of BDR) \\
\hline 8 & & & NRF Reactor $1-200,000$ Gallons \\
\hline 9 & & & \\
\hline 10 & & & \\
\hline 11 & TIME & TANK 49 & NRF TANK \\
\hline 12 & DAYS & MNO2 & MNO2 \\
\hline 13 & 0 & 0.066 & 0.036 \\
\hline 14 & 15 & 0.061 & 0.031 \\
\hline 15 & 30 & 0.056 & 0.026 \\
\hline 16 & 45 & 0.051 & 0.021 \\
\hline 17 & 60 & 0.046 & 0.016 \\
\hline 18 & 75 & 0.041 & 0.011 \\
\hline 19 & 90 & 0.066 & 0.006 \\
\hline 20 & 105 & 0.061 & $=\left(21250^{\circ}(E 19 \cdot 0.005)+178750^{\circ}(F 19-0.005)\right) / 200000$ \\
\hline 21 & 120 & 0.056 & $=\left(21250^{\circ}(E 20 \cdot 0.005)+178750^{\circ}(F 20.0 .005)\right) / 200000$ \\
\hline 22 & 135 & 0.051 & $=\left(21250^{\circ}(E 21 \cdot 0.005)+178750^{\circ}(F 21 \cdot 0.005)\right) / 200000$ \\
\hline 23 & 150 & 0.046 & $=\left(21250^{\circ}(E 22 \cdot 0.005)+178750^{\circ}(F 22 \cdot 0.005)\right) / 200000$ \\
\hline 24 & 165 & 0.041 & $=\left(21250^{\circ}(E 23-0.005)+178750^{\circ}(F 23-0.005)\right) / 200000$ \\
\hline 25 & 180 & 0.066 & $=\left(21250^{\circ}(E 24 \cdot 0.005)+178750^{\circ}(F 24-0.005)\right) / 200000$ \\
\hline 26 & 195 & 0.061 & $=\left(21250^{\circ}(E 25-0.005)+178750^{\circ}(\right.$ F25-0.005))/200000 \\
\hline 27 & 210 & 0.056 & $=\left(21250^{\circ}(E 26 \cdot 0.005)+178750^{\circ}(F 26-0.005)\right) / 200000$ \\
\hline 28 & 225 & 0.051 & $=\left(21250^{\circ}(E 27-0.005)+178750^{\circ}(F 27-0.005)\right) / 200000$ \\
\hline 29 & 240 & 0.046 & $=\left(21250^{\circ}(E 28-0.005)+178750^{\circ}(\right.$ F28-0.005))/200000 \\
\hline 30 & 255 & 0.041 & $=\left(21250^{\circ}(E 29-0.005)+178750^{\circ}(F 29-0.005)\right) / 200000$ \\
\hline 31 & 270 & 0.066 & $=\left(21250^{\circ}(E 30-0.005)+178750^{\circ}(F 30-0.005)\right) / 200000$ \\
\hline 32 & 285 & 0.061 & $=\left(21250^{\circ}(E 31-0.005)+178750^{\circ}(F 31-0.005)\right) / 200000$ \\
\hline 33 & 300 & 10.056 & $=\left(21250^{\circ}(E 32-0.005)+178750^{\circ}(\right.$ F32-0.005))/200000 \\
\hline 34 & 315 & 0.051 & $=\left(21250^{\circ}(E 33-0.005)+178750^{\circ}(\right.$ F33-0.005))/200000 \\
\hline 35 & 330 & 0.046 & $=\left(21250^{\circ}(E 34-0.005)+178750^{\circ}(F 34-0.005)\right) / 200000$ \\
\hline 36 & 345 & 0.041 & $=\left(21250^{\circ}(E 35 \cdot 0.005)+178750^{\circ}(\right.$ F35-0.005))/200000 \\
\hline 37 & 360 & 0.066 & $=\left(21250^{\circ}(E 36-0.005)+178750^{\circ}(F 36-0.005)\right) / 200000$ \\
\hline 38 & 375 & 0.061 & $=\left(21250^{\circ}(E 37-0.005)+178750^{\circ}(\right.$ F37-0.005))/200000 \\
\hline 39 & 390 & 0.056 & $=\left(21250^{\circ}(E 38-0.005)+178750^{\circ}(\right.$ F38-0.005))/200000 \\
\hline 40 & 405 & 0.051 & $-\left(21250^{\circ}(E 39-0.005)+178750^{\circ}(\right.$ F39-0.005))/200000 \\
\hline 41 & 420 & 0.046 & $=\left(21250^{\circ}(E 40-0.005)+178750^{\circ}(F 40-0.005)\right) / 200000$ \\
\hline 42 & & 0.041 & $=\left(21250^{\circ}(E 41-0.005)+178750^{\circ}(F 41-0.005)\right) / 200000$ \\
\hline
\end{tabular}




\begin{tabular}{|c|c|c|c|}
\hline & $\bar{E}$ & $F$ & $\mathbf{G}$ \\
\hline 1 & & & NRF REACTOR SIZE STUDY CASE 2 \\
\hline 2 & & & Cs $=36 \mathrm{Ci} / \mathrm{Gal}$ (Average all waste) \\
\hline 3 & & & NO2 Destruction Rate $=0.01 \mathrm{M} / \mathrm{Mon}$. \\
\hline 4 & & & TK-49 Temp. $=50^{\circ} \mathrm{C}$ \\
\hline 5 & & & TK-49 Sample Cycle $=3$ Months \\
\hline 6 & & & TK.49 NO2 Range $=0.036$ TO $0.066 \mathrm{M}$ \\
\hline 7 & & & Process Rate $=42,500 \mathrm{Gal} / \mathrm{Mon}(75 \%$ of $\mathrm{BDR})$ \\
\hline 8 & & & NRF Reactors $2-95.000$ jallons \\
\hline 9 & & & \\
\hline 10 & & & \\
\hline 11 & & & \\
\hline 12 & & & \\
\hline 13 & TIME & TK 49 & NRF-1 \\
\hline 14 & DAYS & MNO2 & MNO2 (FORMULA) \\
\hline 15 & 0 & 0.066 & 0.036 \\
\hline 16 & 15 & 0.061 & 0.031 \\
\hline 17 & 30 & 0.056 & 0.026 \\
\hline 18 & 45 & 0.051 & 0.021 \\
\hline 19 & 60 & 0.046 & 0.016 \\
\hline 20 & 75 & 0.041 & 0.011 \\
\hline 21 & 90 & 0.066 & 0.006 \\
\hline 22 & 105 & 0.061 & $=\left(21250^{\circ}(F 21-0.005)+73750^{\circ}(G 21-0.005)\right) / 95000$ \\
\hline 23 & 120 & 0.056 & $=\left(21250^{\circ}(\mathrm{F} 22-0.005)+73750^{\circ}(\mathrm{G} 22-0.005)\right) / 95000$ \\
\hline 24 & 135 & $0.051^{\circ}$ & $=\left(21250^{\circ}(\right.$ F23-0.005)+73750*(G23-0.005))/95000 \\
\hline 25 & 150 & 0.046 & $=\left(21250^{\circ}(\mathrm{F} 24 \cdot 0.005)+73750^{\circ}(\mathrm{G} 24-0.005)\right) / 95000$ \\
\hline 26 & 165 & 0.041 & $=\left(21250^{\circ}(\mathrm{F} 25 \cdot 0.005)+73750^{\circ}(\mathrm{G} 25-0.005)\right) / 95000$ \\
\hline 27 & 180 & 0.066 & $=\left(21250^{\circ}(F 26 \cdot 0.005)+73750^{\circ}(\right.$ G26-0.005) $) / 95000$ \\
\hline 28 & 195 & 0.061 & $\left.=\left(21250^{\circ}(F 27-0.005)+73750^{\circ}: G 27-0.005\right)\right) / 95000$ \\
\hline 29 & 210 & 0.056 & $=\left(21250^{\circ}(F 28 \cdot 0.005)+73750^{\circ}(\right.$ G28.0.005) $) / 95000$ \\
\hline 30 & 225 & 0.051 & $=\left(21250^{\circ}\left(\right.\right.$ F29-0.005) $+73750^{\circ}($ G29-0.005) $) / 95000$ \\
\hline 31 & 240 & 0.046 & $=\left(21250^{\circ}(F 30.0 .005)+73750^{\circ}(G 30.0 .005)\right) / 95000$ \\
\hline 32 & 255 & 0.041 & $=\left(21250^{\circ}(\mathrm{F} 31-0.005)+73750^{\circ}(\mathrm{G} 31-0.005)\right) / 95000$ \\
\hline 33 & 270 & 0.066 & $=\left(21250^{\circ}(F 32 \cdot 0.005)+? 3750^{\circ}(\mathrm{G} 32 \cdot 0.005)\right) / 95000$ \\
\hline 34 & 285 & 0.061 & $=\left(21250^{\circ}(\mathrm{F} 33-0.005)+73750^{\circ}(\mathrm{G} 33-0.005)\right) / 95000$ \\
\hline 35 & 300 & 0.056 & $=\left(21250^{\circ}(\mathrm{F} 34-0.005)+73750^{\circ}(\mathrm{G} 34-0.005)\right) / 95000$ \\
\hline 36 & 315 & 0.051 & $=\left(21250^{\circ}(F 35 \cdot 0.005)+73750^{\circ}(\mathrm{G} 35 \cdot 0.005)\right) / 95000$ \\
\hline 37 & 330 & 0.046 & $=\left(21250^{\circ}(\mathrm{F} 36-0.005)+73750^{\circ}(\mathrm{G} 36-0.005)\right) / 95000$ \\
\hline 38 & 345 & 0.041 & $=\left(21250^{\circ}(\mathrm{F} 37 \cdot 0.005)+73750^{\circ}(\mathrm{G} 37 \cdot 0.005)\right) / 95000$ \\
\hline 39 & 360 & 0.066 & $=\left(21250^{\circ}(F 38-0.005)+73750^{\circ}(G 38-0.005)\right) / 95000$ \\
\hline 40 & 375 & 0.061 & $=\left(21250^{\circ}(F 39-0.005)+73750^{\circ}(G 39-0.005)\right) / 95000$ \\
\hline 41 & 390 & 0.056 & $=\left(21250^{\circ}(F 40.0 .005)+73750^{\circ}(G 40-0.005)\right) / 95000$ \\
\hline 42 & 405 & 0.051 & $=\left(21250^{\circ}(F 41-0.005)+73750^{\circ}(G 41-0.005)\right) / 95000$ \\
\hline 43 & 420 & 0.046 & $=\left(21250^{\circ}(F 42 \cdot 0.005)+73750^{\circ}(G 42-0.005)\right) / 95000$ \\
\hline 44 & 435 & 0.041 & $=\left(21250^{\circ}(\mathrm{F} 43 \cdot 0.005)+73750^{\circ}(\mathrm{G} 43.0 .005)\right) / 95000$ \\
\hline
\end{tabular}




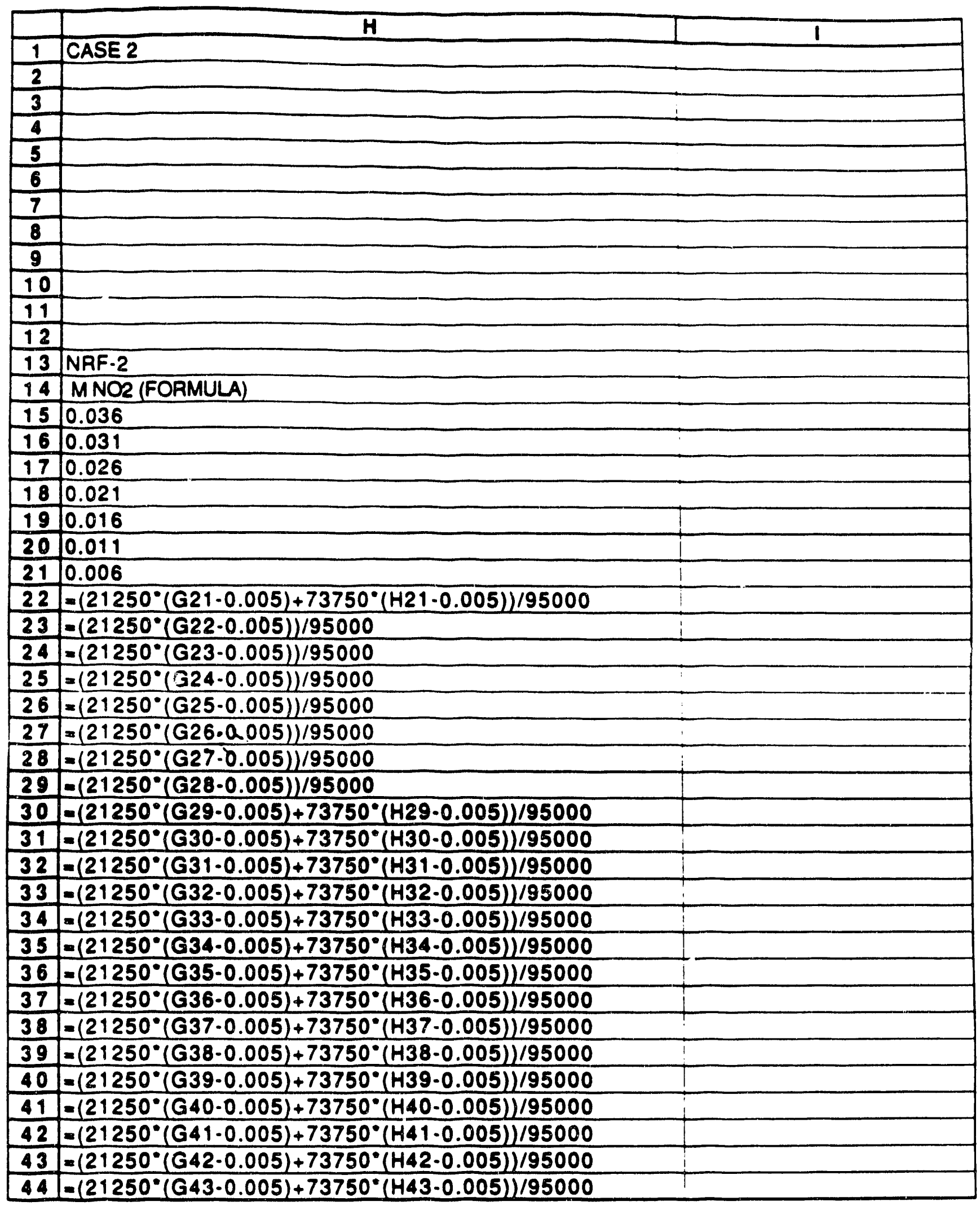




\begin{tabular}{|c|c|c|c|}
\hline & $\boldsymbol{F}$ & $\mathbf{G}$ & $\bar{H}$ \\
\hline 1 & & & NRF REACTOR SIZE STUDY CASE 3 \\
\hline 2 & & & Cs Conc $=36 \mathrm{Ci} / \mathrm{Gal}$ \\
\hline 3 & & & NO2 Destruction Rate $=0.01$ MMMon. \\
\hline 4 & & & Tk-49 Temp. $=50^{\circ} \mathrm{C}$ \\
\hline 5 & & & Tk-49 Sample Cycle $=3$ Months \\
\hline 6 & & & Tk-49 NO2 Range 0.036-0.066 M \\
\hline 7 & & & Process Rate $=42,500 \mathrm{Gal} / \mathrm{Mon}(75 \%$ of BDR) \\
\hline 8 & & & NRF Reaclors $3-62,000$ Gallons \\
\hline 9 & & & \\
\hline 10 & TIME & TANK 49 & NRF.1 \\
\hline 11 & DAYS & MNO2 & MNO2 \\
\hline 12 & 0 & 0.066 & 0.036 \\
\hline 13 & 15 & 0.061 & 0.031 \\
\hline 14 & 30 & 0.056 & 0.026 \\
\hline 15 & 45 & 0.051 & 0.021 \\
\hline 16 & 60 & 0.046 & 0.016 \\
\hline 17 & 75 & 0.041 & 0.011 \\
\hline 18 & 90 & 0.066 & $=\left(21250^{\circ}(\mathrm{G} 17 \cdot 0.005)+40750^{\circ}(\mathrm{H} 17.0 .005)\right) / 62000$ \\
\hline 19 & 105 & 0.061 & $=\left(21250^{\circ}(\mathrm{G} 18-0.005)+40750^{\circ}(\mathrm{H} 18-0.005)\right) / 62000$ \\
\hline 20 & 120 & 0.056 & $=\left(21250^{\circ}(\mathrm{G} 19-0.005)+40750^{\circ}(\mathrm{H} 19-0.005)\right) / 62000$ \\
\hline 21 & 135 & 0.051 & $=\left(21250^{\circ}(\mathrm{G} 20-0.005)+40750^{\circ}(\mathrm{H} 20-0.005)\right) / 62000$ \\
\hline 22 & 150 & 0.046 & $=\left(21250^{\circ}(\mathrm{G} 21 \cdot 0.005)+40750^{\circ}(\mathrm{H} 21-0.005)\right) / 62000$ \\
\hline 23 & 165 & 0.041 & $=\left(21250^{\circ}(\mathrm{G} 22.0 .005)+40750^{\circ}(\mathrm{H} 22.0 .005)\right) / 62000$ \\
\hline 24 & 180 & 0.068 & $-\left(21250^{\circ}(\mathrm{G} 23-0.005)+40750^{\circ}(\mathrm{H} 23-0.005)\right) / 62000$ \\
\hline 25 & 195 & 0.061 & $=\left(21250^{\circ}(\mathrm{G} 24-0.005)+40750^{\circ}(\mathrm{H} 24-0.005)\right) / 62000$ \\
\hline 26 & 210 & 0.056 & $=\left(21250^{\circ}(\mathrm{G} 25-0.005)+40750^{\circ}(\mathrm{H} 25-0.005)\right) / 62000$ \\
\hline 27 & 225 & 0.051 & $=\left(21250^{\circ}(\mathrm{G} 26 \cdot 0.005)+40750^{\circ}(\mathrm{H} 26.0 .005)\right) / 62000$ \\
\hline 28 & 240 & 0,046 & $=\left(21250^{\circ}(\mathrm{G} 27-0.005)+40750^{\circ}(\mathrm{H} 27-0.005)\right) / 62000$ \\
\hline 29 & 255 & 0.041 & $=\left(21250^{\circ}(\mathrm{G} 28-0.005)+40750^{\circ}(\mathrm{H} 28-0.005)\right) / 62000$ \\
\hline 30 & 270 & 0.066 & $=\left(21250^{\circ}(\mathrm{G} 29-0.005)+40750^{\circ}(\mathrm{H} 29-0.005)\right) / 62000$ \\
\hline 31 & 285 & 0.061 & $=\left(21250^{\circ}(\mathrm{G} 30.0 .005)+40750^{\circ}(\mathrm{H} 30.0 .005)\right) / 62000$ \\
\hline 32 & 300 & 0.056 & $=\left(21250^{\circ}(\mathrm{G} 31 \cdot 0.005)+40750^{\circ}(\mathrm{H} 31 \cdot 0.005)\right) / 62000$ \\
\hline 33 & 315 & 0.051 & $-\left(21250^{\circ}(\mathrm{G} 32 \cdot 0.005)+40750^{\circ}(\mathrm{H} 32 \cdot 0.005)\right) / 62000$ \\
\hline 34 & 330 & 0.046 & $=\left(21250^{\circ}(\mathrm{G} 33-0.005)+40750^{\circ}(\mathrm{H} 33-0.005)\right) / 62000$ \\
\hline 35 & 345 & 0.041 & $=\left(21250^{\circ}(\mathrm{G} 34-0.005)+40750^{\circ}(\mathrm{H} 34-0.005)\right) / 62000$ \\
\hline 36 & 360 & 0.065 & $=\left(21250^{\circ}(\mathrm{G} 35 \cdot 0.005)+40750^{\circ}(\mathrm{H} 35-0.005)\right) / 62000$ \\
\hline 37 & 375 & 0.061 & $-\left(21250^{\circ}(\mathrm{G} 36-0.005)+40750^{\circ}(\mathrm{H} 36-0.005)\right) / 62000$ \\
\hline 38 & 390 & 0.056 & $-\left(21250^{\circ}(\mathrm{G} 37-0.005)+40750^{\circ}(\mathrm{H37-0.005)}) / 62000\right.$ \\
\hline 39 & 405 & 0.051 & $=\left(21250^{\circ}(\mathrm{G} 38.0 .005)+40750^{\circ}(\mathrm{H} 38.0 .005)\right) / 62000$ \\
\hline 40 & 420 & 0.046 & $=\left(21250^{\circ}(\mathrm{G} 39-0.005)+40750^{\circ}(\mathrm{H} 39-0.005)\right) / 62000$ \\
\hline 41 & & 0.041 & $=\left(21250^{\circ}(\mathrm{G} 40.0 .005)+40750^{\circ}(\mathrm{H} 40.0 .005)\right) / 62000$ \\
\hline
\end{tabular}




\begin{tabular}{|c|c|}
\hline & $\sigma_{2}$ \\
\hline 1 & CASE 3 \\
\hline 2 & \\
\hline 3 & \\
\hline 4 & \\
\hline 5 & \\
\hline 6 & \\
\hline 7 & \\
\hline 8 & \\
\hline 9 & \\
\hline 10 & NRF.2 \\
\hline 11 & MNO2 \\
\hline 12 & 0.036 \\
\hline 13 & 0.031 \\
\hline 14 & 0.026 \\
\hline 15 & 0.021 \\
\hline 16 & 0.016 \\
\hline 17 & 0.011 \\
\hline 18 & $=\left(21250^{\circ}(H 17-0.005)+40750^{\circ}((117-0.005)) / 62000\right.$ \\
\hline 19 & $=\left(21250^{\circ}(\mathrm{H} 18-0.005)+40750^{\circ}((18-0.005)) / 62000\right.$ \\
\hline 20 & $=\left(21250^{\circ}(H 19 \cdot 0.005)+40750^{\circ}(119 \cdot 0.005)\right) / 62000$ \\
\hline 21 & $=\left(21250^{\circ}(\mathrm{H} 20.0 .005)+40750^{\circ}(120-0.005)\right) / 62000$ \\
\hline 22 & $=\left(21250^{\circ}(\mathrm{H} 21-0.005)+40750^{\circ}(121 \cdot 0.005)\right) / 62000$ \\
\hline 23 & $=\left(21250^{\circ}(\mathrm{H} 22-0.005)+40750^{\circ}(122 \cdot 0.005)\right) / 62000$ \\
\hline 24 & $=\left(21250^{\circ}(H 23-0.005)+40750^{\circ}(123-0.005)\right) / 62000$ \\
\hline 25 & $=\left(21250^{\circ}(\mathrm{H} 24-0.005)+40750^{\circ}(124 \cdot 0.005)\right) / 62000$ \\
\hline 26 & $=\left(21250^{\circ}(\mathrm{H} 25 \cdot 0.005)+40750^{\circ}(125 \cdot 0.005)\right) / 62000$ \\
\hline 27 & $=\left(21250^{\circ}(\mathrm{H} 26.0 .005)+40750^{\circ}(126 \cdot 0.005)\right) / 62000$ \\
\hline 28 & $=\left(21250^{\circ}(H 27 \cdot 0.005)+40750^{\circ}(127 \cdot 0.005)\right) / 62000$ \\
\hline 29 & $=\left(21250^{\circ}(H 28.0 .005)+4075 v^{\prime}(128.0 .005)\right) / 62000$ \\
\hline 30 & $=\left(21250^{\circ}(\mathrm{H} 29-0.005)+40750^{\circ}(129-0.005)\right) / 62000$ \\
\hline 31 & $=\left(21250^{\circ}(\mathrm{H} 30.0 .005)+40750^{\circ}(130.0 .005)\right) / 62000$ \\
\hline 32 & $=\left(21250^{\circ}(H 31-0.005)+40750^{\circ}(131-0.005)\right) / 62000$ \\
\hline 33 & $=\left(21250^{\circ}(\mathrm{H} 32.0 .005)+40750^{\circ}(132.0 .005)\right) / 62000$ \\
\hline 34 & $=\left(21250^{\circ}(\mathrm{H} 33.0 .005)+40750^{\circ}(133.0 .005)\right) / 62000$ \\
\hline 35 & $=\left(21250^{\circ}(H 34-0.005)+40750^{\circ}(134-0.005)\right) / 62000$ \\
\hline 36 & $=\left(21250^{\circ}(H 35-0.005)+40750^{\circ}(135-0.005)\right) / 62000$ \\
\hline 37 & $=\left(21250^{\circ}(H 36 \cdot 0.005)+40750^{\circ}(136 \cdot 0.005)\right) / 62000$ \\
\hline 38 & $=\left(21250^{\circ}(H 37-0.005)+40750^{\circ}(137-0.005)\right) / 62000$ \\
\hline 39 & $=\left(21250^{\circ}(H 38.0 .005)+40750^{\circ}(138.0 .005)\right) / 62000$ \\
\hline 40 & $=\left(21250^{\circ}(H 39 \cdot 0.005)+40750^{\circ}(139-0.005)\right) / 62000$ \\
\hline 41 & $=\left(21250^{\circ}(H 40.0 .005)+40750^{\circ}(140.0 .005)\right) / 62000$ \\
\hline
\end{tabular}




\begin{tabular}{|c|c|}
\hline & J \\
\hline 1 & CASE 3 \\
\hline$\frac{1}{2}$ & \\
\hline 3 & \\
\hline 4 & \\
\hline 5 & \\
\hline 6 & \\
\hline 7 & \\
\hline 8 & \\
\hline 9 & \\
\hline 10 & NAF-3 \\
\hline 11 & MNO2 \\
\hline 12 & 0.036 \\
\hline 13 & 0.031 \\
\hline 14 & 0.026 \\
\hline 15 & 0.021 \\
\hline 16 & 0.016 \\
\hline 17 & 0.011 \\
\hline 18 & $=\left(21250^{\circ}(117.0 .005)+40750^{\circ}(J 17.0 .005)\right) / 62000$ \\
\hline 19 & $=\left(21250^{\circ}(118.0 .005)+40750^{\circ}(J 18 \cdot 0.005)\right) / 62000$ \\
\hline 20 & 9 \\
\hline 21 & $=\left(21250^{\circ}(120 \cdot 0.005)\right) / 62000$ \\
\hline 22 & $=\left(21250^{\circ}(121 \cdot 0.005)\right) / 62000$ \\
\hline 23 & $=\left(21250^{\circ}(122-0.005)\right) / 62000$ \\
\hline 24 & $=\left(21250^{\circ}(123 \cdot 0.005)\right) / 62000$ \\
\hline 25 & $.\left(21250^{\circ}(124-0.005)\right) / 62000$ \\
\hline 26 & $=\left(21250^{\circ}(125 \cdot 0.005)\right) / 62000$ \\
\hline 27 & $=\left(21250^{\circ}(126: 0: 005)\right) / 62000$ \\
\hline 28 & $=\left(21250^{\circ}(127 \cdot 0.005)+40750^{\circ}(127 \cdot 0.005)\right) / 62000$ \\
\hline 29 & $=\left(21250^{\circ}(128-0.005)+40750^{\circ}(\mathrm{J} 28 \cdot 0.005)\right) / 62000$ \\
\hline 30 & $=\left(21250^{\circ}(129 \cdot 0.005)+40750^{\circ}(\mathrm{J} 29 \cdot 0.005)\right) / 62000$ \\
\hline 31 & $=\left(21250^{\circ}(130-0.005)+40750^{\circ}(\mathrm{J} 30.0 .005)\right) / 62000$ \\
\hline 32 & $=\left(21250^{\circ}(131-0.005)+40750^{\circ}(\mathrm{J} 31.0 .005)\right) / 62000$ \\
\hline 33 & $=\left(21250^{\circ}(132-0.005)+40750^{\circ}(\mathrm{J} 32-0.005)\right) / 62000$ \\
\hline 34 & $=\left(21250^{\circ}(133 \cdot 0.005)+40750^{\circ}(\sqrt{33} \cdot 0.005)\right) / 62000$ \\
\hline 35 & $=\left(21250^{\circ}(134-0.005)+40750^{\circ}(\mathrm{J} 34-0.005)\right) / 62000$ \\
\hline$\overline{36}$ & $=\left(21250^{\circ}(135-0.005)+40750^{\circ}(\mathrm{J} 35 \cdot 0.005)\right) / 62000$ \\
\hline 39 & $=\left(21250^{\circ}(136-0.005)+40750^{\circ}(\mathrm{J} 36 \cdot 0.005)\right) / 62000$ \\
\hline 38 & $=\left(21250^{\circ}(137-0.005)+40750^{\circ}(\mathrm{J} 37.0 .005)\right) / 62000$ \\
\hline 39 & $=\left(21250^{\circ}(138.0 .005)+40750^{\circ}(\mathrm{J} 38 \cdot 0.005)\right) / 62000$ \\
\hline 40 & $=\left(21250^{\circ}(139-0.005)+40750^{\circ}(\mathrm{J} 39-0.005)\right) / 62000$ \\
\hline 41 & $=\left(21250^{\circ}(140-0.005)+40750^{\circ}(\mathrm{J} 40.0 .005) / 62000\right.$ \\
\hline
\end{tabular}




\begin{tabular}{|c|c|c|c|}
\hline & $E$ & $\mathbf{F}$ & $\mathbf{G}$ \\
\hline 1 & & & NRF REACTOR SIZE STUDY CASE 4 \\
\hline 2 & & & Cs $-23.2 \mathrm{Ci} / \mathrm{Gal}$ \\
\hline 3 & & & NO2 Destruction Rate $=0.0064 \mathrm{M} / \mathrm{Mon}$. \\
\hline 4 & & & TK-49 Temp. $=50^{\circ} \mathrm{C}$ \\
\hline$\frac{1}{5}$ & & & TK-49 Sample Cycle $=3$ Months \\
\hline 6 & & & TK-49 NO2 Range $=0.036$ TO $0.055 \mathrm{M}$ \\
\hline 7 & & & Process Rate $=42.500 \mathrm{Gal} / \mathrm{Mon}(75 \%$ of $\mathrm{BDR})$ \\
\hline 8 & & & NRF Reactors $2 \cdot 120,000$ gallons \\
\hline 9 & & & 1 \\
\hline 10 & TIME & TK 49 & NRF-1 \\
\hline 11 & DAYS & MNO2 (FORM) & MNO2 (FORMULA) \\
\hline 12 & 0 & 0.055 & 0.036 \\
\hline 13 & 15 & $=F 12 \cdot 0.0032$ & $=G 12 \cdot 0.0032$ \\
\hline 14 & 30 & $=F 13 \cdot 0.0032$ & $=G 13 \cdot 0.0032$ \\
\hline 15 & 45 & $=F 14 \cdot 0.0032$ & $=G 14 \cdot 0.0032$ \\
\hline 16 & 60 & $-F 15 \cdot 0.0032$ & $=\mathrm{G} 15 \cdot 0.0032$ \\
\hline 17 & 75 & $-F 16 \cdot 0.0032$ & $=G 16 \cdot 0.0032$ \\
\hline 18 & 90 & 0.055 & $=G 17.0 .0032$ \\
\hline 19 & 105 & $=F 18-0.0032$ & $-G 18 \cdot 0.0032$ \\
\hline 20 & 120 & $-F 19 \cdot 0.0032$ & $-G 19 \cdot 0.0032$ \\
\hline 21 & 135 & $-F 20 \cdot 0.0032$ & $-G 20 \cdot 0.0032$ \\
\hline 22 & 150 & $-F 21-0.0032$ & $=\left(21250^{\circ}(F 21-0.0032)+98750^{\circ}(\right.$ G21-0.0032) $) / 120000$ \\
\hline 23 & 165 & $=F 22 \cdot 0.0032$ & $=\left(21250^{\circ}(\mathrm{F} 22 \cdot 0.0032)+98750^{\circ}(\mathrm{G} 22-0.0032)\right) / 120000$ \\
\hline 24 & 180 & 0.055 & $=\left(21250^{\circ}(\mathrm{F} 23-0.0032)+98750^{\circ}(\mathrm{G} 23 \cdot 0.0032)\right) / 120000$ \\
\hline 25 & 195 & $=F 24 \cdot 0.0032$ & $=\left(21250^{\circ}(\mathrm{F} 24-0.0032)+98750^{\circ}(\mathrm{G} 24 \cdot 0.0032)\right) / 120000$ \\
\hline 26 & 210 & $=F 25 \cdot 0.0032$ & $=\left(21250^{\circ}(\mathrm{F} 25 \cdot 0.0032)+98750^{\circ}(\mathrm{G} 25 \cdot 0.0032)\right) / 120000$ \\
\hline 27 & 225 & $=F 26-0.0032$ & $=\left(21250^{\circ}\left(F^{2} 6-0.0032\right)+98750^{\circ}(G 26-0.0032)\right) / 120000$ \\
\hline 28 & 240 & $-F 27.0 .0032$ & $=\left(21250^{\circ}(\mathrm{F} 27-0.0032)+98750^{\circ}(\mathrm{G} 27-0.0032)\right) / 120000$ \\
\hline 29 & 255 & $-F 28-0.0032$ & $=\left(21250^{\circ}\left(\right.\right.$ F28-0.0032) $+98750^{\circ}($ G28-0.0032) $) / 120000$ \\
\hline 30 & 270 & 0.055 & $=\left(21250^{\circ}\left(\right.\right.$ F29-0.0032) $+98750^{\circ}($ G29-0.0032) $) / 120000$ \\
\hline 31 & 285 & $=F 30 \cdot 0.0032$ & $-\left(21250^{\circ}(F 30-0.0032)+98750^{\circ}(\mathrm{G} 30-0.0032)\right) / 120000$ \\
\hline 32 & 300 & $-F 31 \cdot 0.0032$ & $\left(21250^{\circ}\left(\right.\right.$ F31-0.0032) $+98750^{\circ}($ G31-0.0032) $) / 120000$ \\
\hline 33 & 315 & $-F 32 \cdot 0.0032$ & $=\left(21250^{\circ}(F 32-0.0032)+98750^{\circ}(\mathrm{G} 32-0.0032)\right) / 120000$ \\
\hline 34 & 330 & $-F 33-0.0032$ & $=\left(21250^{\circ}(\mathrm{F} 33-0.0032)+98750^{\circ}(\mathrm{G} 33-0.0032)\right) / 120000$ \\
\hline 35 & 345 & $-F 34-0.0032$ & $=\left(21250^{\circ}(\mathrm{F} 34-0.0032)+98750^{\circ}(\mathrm{G} 34-0.0032)\right) / 120000$ \\
\hline 36 & 360 & 0.055 & $=\left(21250^{\circ}(\right.$ F $35 \cdot 0.0032)+98750^{\circ}($ G35-0.0032) $) / 120000$ \\
\hline 37 & 375 & $-F 36-0.0032$ & $=\left(21250^{\circ}(\mathrm{F} 36-0.0032)+98750^{\circ}(\mathrm{G} 36-0.0032)\right) / 120000$ \\
\hline 38 & 390 & $-F 37-0.0032$ & $=\left(21250^{\circ}(F 37-0.0032)+98750^{\circ}(G 37-0.0032)\right) / 120000$ \\
\hline 39 & 405 & $=F 38-0.0032$ & $=\left(21250^{\circ}(\mathrm{F} 38-0.0032)+98750^{\circ}(\mathrm{G} 38-0.0032)\right) / 120000$ \\
\hline 40 & 420 & $=F 39 \cdot 0.0032$ & $-\left(21250^{\circ}(F 39-0.0032)+98750^{\circ}(G 39-0.0032)\right) / 120000$ \\
\hline 41 & 435 & $-F 40-0.0032$ & $=\left(21250^{\circ}(F 40.0 .0032)+98750^{\circ}(G 40-0.0032)\right) / 120000$ \\
\hline
\end{tabular}




\begin{tabular}{|c|c|}
\hline & $\mathbf{H}$ \\
\hline 1 & CASE 4 \\
\hline 2 & \\
\hline 3 & \\
\hline 4 & \\
\hline 5 & \\
\hline 6 & \\
\hline 7 & \\
\hline 8 & \\
\hline 9 & \\
\hline 10 & NRF.2 \\
\hline 11 & MNO2 (FORMULA) \\
\hline 12 & 0.036 \\
\hline 13 & $-H 12 \cdot 0.0032$ \\
\hline 14 & $=H 13 \cdot 0.0032$ \\
\hline 15 & $-414 \cdot 0.0032$ \\
\hline 16 & $=H 15 \cdot 0.0032$ \\
\hline 17 & $=-H 16 \cdot 0.0032$ \\
\hline 18 & $-H 17 \cdot 0.0032$ \\
\hline 19 & $=-H 18-0.0032$ \\
\hline 20 & $=H 19 \cdot 0.0032$ \\
\hline 21 & $-H 20 \cdot 0.0032$ \\
\hline 22 & $=\left(21250^{\circ}(\mathrm{G} 21-0.0032)+98750^{\circ}(\mathrm{H} 21 \cdot 0.0032)\right) / 120000$ \\
\hline 23 & $=\left(21250^{\circ}(\mathrm{G} 22 \cdot 0.0032)+98750^{\circ}(\mathrm{H} 22 \cdot 0.0032)\right) / 120000$ \\
\hline 24 & $-\left(21250^{\circ}(G 23.0 .0032)\right) / 120000$ \\
\hline 25 & $=\left(21250^{\circ}(G 24-0.0032)\right) / 120000$ \\
\hline 26 & $-\left(21250^{\circ}(\mathrm{G} 25 \cdot 0.0032)\right) / 120000$ \\
\hline 27 & $-\left(21250^{\circ}(G 26 \cdot 0.0032)\right) / 120000$ \\
\hline 28 & $=\left(21250^{\circ}(G 27: 0.0032)\right) / 120000$ \\
\hline 29 & $=\left(21250^{\circ}(G 28 \cdot 0.0032)+98750^{\circ}(\mathrm{H} 28 \cdot 0.0032)\right) / 120000$ \\
\hline 30 & $=\left(21250^{\circ}(\mathrm{G} 29 \cdot 0.0032)+98750^{\circ}(\mathrm{H} 29 \cdot 0.0032)\right) / 120000$ \\
\hline 31 & $=\left(21250^{\circ}(\mathrm{G} 30 \cdot 0.0032)+98750^{\circ}(\mathrm{H} 30 \cdot 0.0032)\right) / 120000$ \\
\hline 32 & $=\left(21250^{\circ}(\mathrm{G} 31 \cdot 0.0032)+98750^{\circ}(\mathrm{H} 31 \cdot 0.0032)\right) / 120000$ \\
\hline 33 & $-\left(21250^{\circ}(G 32 \cdot 0.0032)+98750^{\circ}(H 32 \cdot 0.0032)\right) / 120000$ \\
\hline 34 & $=\left(21250^{\circ}(\mathrm{G} 33-0.0032)+98750^{\circ}(\mathrm{H} 33 \cdot 0.0032)\right) / 120000$ \\
\hline 35 & $=\left(21250^{\circ}(G 34-0.0032)+98750^{\circ}(H 34-0.0032)\right) / 120000$ \\
\hline 36 & $=\left(21250^{\circ}(\mathrm{G} 35-0.0032)+98750^{\circ}(\mathrm{H} 35 \cdot 0.0032)\right) / 120000$ \\
\hline 37 & $=\left(21250^{\circ}(\mathrm{G} 36 \cdot 0.0032)+98750^{\circ}(\mathrm{H} 36 \cdot 0.0032)\right) / 120000$ \\
\hline 38 & $=\left(21250^{\circ}(G 37 \cdot 0.0032)+98750^{\circ}(H 37 \cdot 0.0032)\right) / 120000$ \\
\hline 39 & $=\left(21250^{\circ}(G 38.0 .0032)+98750^{\circ}(H 38.0 .0032)\right) / 120000$ \\
\hline 40 & $=\left(21250^{\circ}(G 39-0.0032)+98750^{\circ}(H 39-0.0032)\right) / 120000$ \\
\hline 41 & $=\left(21250^{\circ}(G 40 \cdot 0.0032)+98750^{\circ}(H 40 \cdot 0.0032)\right) / 120000$ \\
\hline
\end{tabular}




\begin{tabular}{|c|c|c|c|}
\hline & $\mathbf{E}$ & $\mathbf{F}$ & $\mathbf{G}$ \\
\hline 1 & & & NRF REACTOA SIZE STUDY CASE 5 \\
\hline 2 & & 1 & Cs $-19 \mathrm{Ci} / \mathrm{Gal}$ \\
\hline 3 & & & NO2 Destruction Rate- 0.053 M/Mon. \\
\hline 4 & & & TK.49 Temp. $=50^{\circ} \mathrm{C}$ \\
\hline $\mathbf{5}$ & & & TK-49 Sample Cycle - 3 Months \\
\hline 6 & & & TK-49 NO2 Range $=0.036$ TO $0.052 \mathrm{M}$ \\
\hline 7 & & & Process Rate $=42.500$ Galmon ( $75 \%$ of BDR) \\
\hline 8 & & & NRF Reactors 2-140,000 gallons \\
\hline 9 & & & \\
\hline 10 & TIME & TK 49 & NRF.1 \\
\hline 11 & DAYS & MNO2 FOAMUL & MNO2 FORMULA \\
\hline 12 & 0 & 0.052 & 0.036 \\
\hline 13 & 15 & $=F 12 \cdot 0.0026$ & $=G 12 \cdot 0.0026$ \\
\hline 14 & 30 & $=F 13 \cdot 0.0026$ & $=G 13-0.0026$ \\
\hline 15 & 45 & $=F 14 \cdot 0.0026$ & $=G 14-0.0026$ \\
\hline 16 & 60 & $=F 15 \cdot 0.0026$ & $=\mathrm{G} 15 \cdot 0.0026$ \\
\hline 17 & 75 & $=F 16 \cdot 0.0026$ & $=G 16-0.0026$ \\
\hline 18 & 90 & 0.052 & $=\mathrm{G} 17 \cdot 0.0026$ \\
\hline 19 & 105 & $=F 18.0 .0026$ & $=G 18-0.0026$ \\
\hline 20 & 120 & $-F 19 \cdot 0.0026$ & $=G 19.0 .0026$ \\
\hline 21 & 135 & $-F 20.0 .0026$ & $-G 20.0 .0026$ \\
\hline 22 & 150 & $=F 21-0.0026$ & $-G 21-0.0026$ \\
\hline 23 & 165 & $-F 22 \cdot 0.0026$ & $=\left(21250^{\circ}(\mathrm{F} 22 \cdot 0.0026)+118750^{\circ}(\mathrm{G22} \cdot 0.0026)\right) / 140000$ \\
\hline 24 & 180 & 0.052 & $-\left(21250^{\circ}(\mathrm{F} 23.0 .0026)+118750^{\circ}(\mathrm{G23}-0.0026)\right) / 140000$ \\
\hline 25 & 195 & $-F 24-0.0026$ & $=\left(21250^{\circ}(\mathrm{F} 24 \cdot 0.0026)+118750^{\circ}(\mathrm{G} 24 \cdot 0.0026)\right) / 140000$ \\
\hline 26 & 210 & $=F 25 \cdot 0.0026$ & $=\left(21250^{\circ}(\mathrm{F} 25 \cdot 0.0026)+118750^{\circ}(\mathrm{G} 25 \cdot 0.0026)\right) / 140000$ \\
\hline 27 & 225 & $=F 26 \cdot 0.0026$ & $=\left(21250^{\circ}(\mathrm{F} 26-0.0026)+118750^{\circ}(\mathrm{G} 26-0.0026)\right) / 140000$ \\
\hline 28 & 240 & $=F 27: 0.0026$ & $=\left(21250^{\circ}(\mathrm{F} 27 \cdot 0.0026)+118750^{\circ}(\mathrm{G} 27 \cdot 0.0026)\right) / 140000$ \\
\hline 29 & 255 & $-F 28-0.0026$ & $=\left(21250^{\circ}(\mathrm{F} 28 \cdot 0.0026)+118750^{\circ}(\mathrm{G} 28.0 .0026)\right) / 140000$ \\
\hline 30 & 270 & 0.052 & $-\left(21250^{\circ}(\mathrm{F} 29 \cdot 0.0026)+118750^{\circ}(\mathrm{G} 29 \cdot 0.0026)\right) / 140000$ \\
\hline 31 & 285 & $-F 30 \cdot 0.0026$ & $=\left(21250^{\circ}(\mathrm{F} 30.0 .0026)+118750^{\circ}(\mathrm{G} 30.0 .0026)\right) / 140000$ \\
\hline 32 & 300 & $-F 31-0.0026$ & $-\left(21250^{\circ}(\right.$ F31.0.0026)+118750*(G31-0.0026) $) / 140000$ \\
\hline 33 & 315 & $-F 32 \cdot 0.0026$ & $-\left(21250^{\circ}(F 32.0 .0026)+118750^{\circ}(\mathrm{G} 32-0.0026)\right) / 140000$ \\
\hline 34 & 330 & $=F 33-0.0026$ & $=\left(21250^{\circ}(\mathrm{F} 33-0.0026)+118750^{\circ}(\mathrm{G} 33-0.0026)\right) / 140000$ \\
\hline 35 & 345 & $-F 34 \cdot 0.0026$ & $-\left(21250^{\circ}(\right.$ F34-0.0026)+118750*(G34-0.0026)/1140000 \\
\hline 36 & 360 & 0.052 & $=\left(21250^{\circ}(F 35-0.0026)+118750^{\circ}(G 35-0.0026)\right) / 140000$ \\
\hline 37 & 375 & $=F 36 \cdot 0.0026$ & $=\left(21250^{\circ}(\mathrm{F} 36-0.0026)+118750^{\circ}(\mathrm{G} 36-0.0026)\right) / 140000$ \\
\hline 38 & 390 & $=F 37 \cdot 0.0026$ & $=\left(21250^{\circ}(\right.$ F $\left.37-0.0026)+118750^{\circ}(\mathrm{G} 37-0.0026)\right) / 140000$ \\
\hline 39 & 405 & $=F 38-0.0026$ & $-\left(21250^{\circ}(\mathrm{F} 38-0.0026)+118750^{\circ}(\mathrm{G} 38-0.0026)\right) / 140000$ \\
\hline 40 & 420 & $=F 39 \cdot 0.0026$ & $=\left(21250^{\circ}(\mathrm{F} 39-0.0026)+118750^{\circ}(\mathrm{G} 39-0.0026)\right) / 140000$ \\
\hline 41 & 435 & $-F 40-0.0026$ & $=\left(21250^{\circ}(F 40.0 .0026)+118750^{\circ}(\mathrm{G} 40.0 .0026)\right) / 140000$ \\
\hline 42 & 450 & 0.052 & $=\left(21250^{\circ}(F 41-0.0026)+118750^{\circ}(G 41-0.0026)\right) / 140000$ \\
\hline 43 & 465 & $-F 42 \cdot 0.0026$ & $-\left(21250^{\circ}(F 42 \cdot 0.0026)+118750^{\circ}(G 42 \cdot 0.0026)\right) / 140000$ \\
\hline 44 & 480 & $=F 43-0.0026$ & $=\left(21250^{\circ}(F 43-0.0026)+118750^{\circ}(\mathrm{G} 43-0.0026)\right) / 140000$ \\
\hline 45 & 495 & $=F 44-0.0026$ & $=\left(21250^{\circ}(F 44-0.0026)+118750^{\circ}(G 44-0.0026)\right) / 140000$ \\
\hline 46 & 510 & $=F 45 \cdot 0.0026$ & $-\left(21250^{\circ}(F 45 \cdot 0.0026)+118750^{\circ}(G 45 \cdot 0.0026)\right) / 140000$ \\
\hline 47 & 525 & $=F 46 \cdot 0.0026$ & $=\left(21250^{\circ}(F 46 \cdot 0.0026)+118750^{\circ}(G 46 \cdot 0.0026)\right) / 140000$ \\
\hline
\end{tabular}




\begin{tabular}{|c|c|}
\hline & $\bar{H}$ \\
\hline 1 & CASE 5 \\
\hline 2 & \\
\hline 3 & \\
\hline 4 & \\
\hline $\mathbf{5}$ & \\
\hline 6 & \\
\hline 7 & \\
\hline$\frac{8}{9}$ & \\
\hline 10 & NRF-2 \\
\hline 11 & MNO2 FORMULA \\
\hline 12 & 0.036 \\
\hline 13 & $=-H 12 \cdot 0.0026$ \\
\hline 14 & $=H 13 \cdot 0.0026$ \\
\hline 15 & $=H 14 \cdot 0.0026$ \\
\hline 16 & $=H 15 \cdot 0.0026$ \\
\hline 17 & $=H 16-0.0026$ \\
\hline 18 & $=-H 17 \cdot 0.0026$ \\
\hline 19 & $=H 18 \cdot 0.0026$ \\
\hline 20 & $-H 19 \cdot 0.0026$ \\
\hline 21 & $=H 20 \cdot 0.0026$ \\
\hline 22 & $=-H 21 \cdot 0.0026$ \\
\hline 23 & $=\left(21250^{\circ}(\mathrm{G} 22 \cdot 0.0026)+118750^{\circ}(\mathrm{H} 22 \cdot 0.0026)\right) / 140000$ \\
\hline 24 & $=\left(21250^{\circ}(G 23.0 .0026)+118750^{\circ}(H 23.0 .0026)\right) / 140000$ \\
\hline 25 & $=\left(21250^{\circ}(G 24-0.0026)+118750^{\circ}(H 24-0.0026)\right) / 140000$ \\
\hline 26 & $=\left(21250^{\circ}(G 25 \cdot 0.0026)+118750^{\circ}(H 25-0.0026)\right) / 140000$ \\
\hline 27 & $=\left(21250^{\circ}(G 26: 0.0026)+118750^{\circ}(H 26-0.0026)\right) / 140000$ \\
\hline 28 & $=\left(21250^{\circ}(G 27 \cdot 0.0026)+118750^{\circ}(H 27-0.0026)\right) / 140000$ \\
\hline 29 & $=\left(21250^{\circ}(\mathrm{G} 28.0 .0026)+118750^{\circ}(\mathrm{H} 28 \cdot 0.0026) / 140000\right.$ \\
\hline 30 & $=\left(21250^{\circ}(G 29 \cdot 0.0026)+118750^{\circ}(H 29-0.0026) / 140000\right.$ \\
\hline 31 & $=\left(21250^{\circ}(G 30.0 .0026)+118750^{\circ}(H 30.0 .0026) / 140000\right.$ \\
\hline 32 & $=\left(21250^{\circ}(G 31 \cdot 0.0026)+118750^{\circ}(H 31-0.0026)\right) / 140000$ \\
\hline 33 & $=\left(21250^{\circ}(\mathrm{G} 32 \cdot 0.0026)+118750^{\circ}(\mathrm{H} 32 \cdot 0.0026) / 140000\right.$ \\
\hline 34 & $=\left(21250^{\circ}(G 33.0 .0026)+118750^{\circ}(H 33.0 .0026) / 140000\right.$ \\
\hline 35 & $=\left(21250^{\circ}(\mathrm{G} 34-0.0026)+118750^{\circ}(\mathrm{H} 34-0.0026) / 140000\right.$ \\
\hline 36 & $=\left(21250^{\circ}(G 35 \cdot 0.0026)+118750^{\circ}(H 35 \cdot 0.0026) / 140000\right.$ \\
\hline 37 & $=\left(21250^{\circ}\left(\right.\right.$ G36-0.0026) $+118750^{\circ}(H 36-0.0026) / 140000$ \\
\hline 38 & $=\left(21250^{\circ}(G 37.0 .0026)+118750^{\circ}(H 37.0 .0026) / / 140000\right.$ \\
\hline 39 & $=\left(21250^{\circ}(G 38.0 .0026)+118750^{\circ}(H 38.0 .0026)\right) / 140000$ \\
\hline 40 & $=\left(21250^{\circ}(G 39.0 .0026)+118750^{\circ}(H 39-0.0026)\right) / 140000$ \\
\hline 41 & $=\left(21250^{\circ}(G 40.0 .0026)+118750^{\circ}(H 40.0 .0026) / / 140000\right.$ \\
\hline 42 & $=\left(21250^{\circ}(G 41.0 .0026)+118750^{\circ}(H 41.0 .0026)\right) / 140000$ \\
\hline 43 & $=\left(21250^{\circ}(G 42 \cdot 0.0026)+118750^{\circ}(H 42 \cdot 0.0026)\right) / 140000$ \\
\hline 44 & $=\left(21250^{\circ}(\mathrm{G} 43.0 .0026)+118750^{\circ}(\mathrm{H} 43.0 .0026) / 140000\right.$ \\
\hline 45 & $=\left(21250^{\circ}(\mathrm{G} 44-0.0026)+118750^{\circ}(\mathrm{H} 44.0 .0026)\right) / 140000$ \\
\hline 46 & $=\left(21250^{\circ}(G 45 \cdot 0.0026)+118750^{\circ}(H 45.0 .0026)\right) / 140000$ \\
\hline 47 & $=\left(21250^{\circ}(G 46.0 .0026)+118750^{\circ}(H 46.0 .0026) / 140000\right.$ \\
\hline
\end{tabular}




\begin{tabular}{|c|c|c|c|}
\hline & $\mathbf{E}$ & $\mathbf{F}$ & $\mathbf{G}$ \\
\hline 1 & & & NAF REACTOR SIZE STUDY CASE 6 \\
\hline 2 & & & Cs $=12.7 \mathrm{Ci} / \mathrm{Gal}$ (Min First 5 Years with 1.5 Safety Factor) \\
\hline 3 & & & NO2 Destruction Rate $=0.0035$ M/Mon. \\
\hline 4 & & & TK-49 Temp. $=50^{\circ} \mathrm{C}$ \\
\hline 5 & & & TK-49 Sample Cycle - 3 Months \\
\hline 6 & & & TK-49 NO2 Range $=0.036100 .047 \mathrm{M}$ \\
\hline 7 & & & Process Rate $=42.500 \mathrm{Gal} / \mathrm{Mon}(75 \%$ of BDR) \\
\hline 8 & & & NAF Reactors $2.170,000$ gallons \\
\hline 9 & & & \\
\hline 10 & TIME & TK 49 & NRF-1 \\
\hline 11 & DAYS & MNO2 & MNO2 \\
\hline 12 & 0 & 0.047 & 0.036 \\
\hline 13 & 15 & $F 12 \cdot 0.0017$ & $=\mathrm{G} 12 \cdot 0.0017$ \\
\hline 14 & 30 & $=F 13-0.0017$ & $=G 13.0 .0017$ \\
\hline 15 & 45 & $=F 14 \cdot 0.0017$ & $=G 14 \cdot 0.0017$ \\
\hline 16 & 60 & $=F 15-0.0017$ & $=\mathrm{G} 15 \cdot 0.0017$ \\
\hline 17 & 75 & $=F 16-0.0017$ & $=\mathrm{G16} 16.00017$ \\
\hline 18 & 90 & 0.047 & $=\mathrm{G} 17 \cdot 0.0017$ \\
\hline 19 & 105 & $-F 18.0 .0017$ & $=G 18-0.0017$ \\
\hline 20 & 120 & $-F 19-0.0017$ & $=\mathbf{G} 19 \cdot 0.0017$ \\
\hline 21 & 135 & $=F 20 \cdot 0.0017$ & $=\mathbf{G} 20 \cdot 0.0017$ \\
\hline 22 & 150 & $=F 21 \cdot 0.0017$ & $=G 21 \cdot 0.0017$ \\
\hline 23 & 165 & $=F 22 \cdot 0.0017$ & $=\mathrm{G} 22 \cdot 0.0017$ \\
\hline 24 & 180 & 0.047 & $=G 23-0.0017$ \\
\hline 25 & 195 & $=F 24-0.0017$ & $=G 24 \cdot 0.0017$ \\
\hline 26 & 210 & $=F 25 \cdot 0.0017$ & $=G 25 \cdot 0.0017$ \\
\hline 27 & 225 & $=F 26 \cdot 0.0017$ & $-G 26 \cdot 0.0017$ \\
\hline 28 & 240 & $=F 27: 0.0017$ & $=G 27-0.0017$ \\
\hline 29 & 255 & $=F 28 \cdot 0.0017$ & $-\left(21250^{\circ}\left(\right.\right.$ F28.0.0017) $+148750^{\circ}($ G28.0.0017) $) / 170000$ \\
\hline 30 & 270 & 0.047 & $-\left(21250^{\circ}(F 29 \cdot 0.0017)+148750^{\circ}(\mathrm{G} 29 \cdot 0.0017)\right) / 170000$ \\
\hline 31 & 285 & $-F 30-0.0017$ & $=\left(21250^{\circ}(\mathrm{F} 30.0 .0017)+148750^{\circ}(\mathrm{G} 30.0 .0017)\right) / 170000$ \\
\hline 32 & 300 & $=F 31-0.0017$ & $-\left(21250^{\circ}(F 31 \cdot 0.0017)+148750^{\circ}(\mathrm{G} 31 \cdot 0.0017)\right) / 170000$ \\
\hline 33 & 315 & $=F 32 \cdot 0.0017$ & $=\left(21250^{\circ}(\right.$ F32-0.0017)+148750 (G32-0.0017))/170000 \\
\hline 34 & 330 & $=\mp 33-0.0017$ & $-\left(21250^{\circ}(\right.$ F33.0.0017)+148750*(G33.0.0017))/170000 \\
\hline 35 & 345 & $-F 34 \cdot 0.0017$ & $=\left(21250^{\circ}(\mathrm{F34} \cdot 0.0017)+148750^{\circ}(\mathrm{G} 34 \cdot 0.0017)\right) / 170000$ \\
\hline 36 & 360 & 0.047 & $-\left(21250^{\circ}(F 35-0.0017)+148750^{\circ}(\right.$ G35-0.0017) $) / 170000$ \\
\hline 37 & 375 & $. F 36-0.0017$ & $=\left(21250^{\circ}\left(\right.\right.$ F36-0.0017) $+148750^{\circ}($ G36-0.0017) $) / 170000$ \\
\hline 38 & 390 & $-F 37-0.00: 7$ & $=\left(21250^{\circ}\left(\right.\right.$ F37.0.0017) $+148750^{\circ}($ G37.0.0017) $) / 170000$ \\
\hline 39 & 405 & $=F 38 \cdot 0.007$ & $=\left(21250^{\circ}(F 38-0.0017)+148750^{\circ}(G 38-0.0017)\right) / 170000$ \\
\hline 40 & 420 & $=F 39 \cdot 0.00 \cdot 7$ & $=\left(21250^{\circ}\right.$ F39-0.0017)+148750*(G39-0.0017))/170000 \\
\hline 41 & 435 & $=F 40-0.0017$ & $\left.=\left(21256^{\circ} \quad F 40.0 .0017\right)+148750^{\circ}(\mathrm{G} 40.0 .0017)\right) / 170000$ \\
\hline 42 & 450 & 0.047 & $\left.=(2125 \quad F 41 \cdot 0.0017)+148750^{\circ}(G 41-0.0017)\right) / 170000$ \\
\hline 43 & 465 & $=F 42 \cdot 0.0017$ & $\left.=(21256 \quad F 42 \cdot 0.0017)+148750^{\circ}(\mathrm{G} 42 \cdot 0.0017)\right) / 170000$ \\
\hline 44 & 480 & $=F 43-0.0017$ & $\left.-(21250 \quad F 43.0 .0017)+148750^{\circ}(G 43.0 .0017)\right) / 170000$ \\
\hline 45 & 495 & $-F 44 \cdot 0.0017$ & $\left.=(2125 \mathrm{C}=44 \cdot 0.0017)+148750^{\circ}(\mathrm{G} 44 \cdot 0.0017)\right) / 170000$ \\
\hline 46 & 510 & $=\mp 45 \cdot 0.0017$ & $\left.=(2125 C=45 \cdot 0.0017)+148750^{\circ}(\mathrm{G} 45 \cdot 0.0017)\right) / 170000$ \\
\hline 47 & 525 & $=F 46 \cdot 0.0017$ & $\left.=(21250 \quad F 46 \cdot 0.0017)+148750^{\circ}(G 46-0.0017)\right) / 170000$ \\
\hline
\end{tabular}




\begin{tabular}{|c|c|}
\hline & $\mathbf{H}$ \\
\hline 1 & CASE 6 \\
\hline 2 & \\
\hline 3 & \\
\hline 4 & \\
\hline 5 & \\
\hline 6 & \\
\hline 7 & \\
\hline 8 & \\
\hline 9 & \\
\hline 10 & NRF-2 \\
\hline 11 & MNO2 \\
\hline 12 & 0.036 \\
\hline 13 & $=H 12 \cdot 0.0017$ \\
\hline 14 & $=H 13 \cdot 0.0017$ \\
\hline 15 & $=H 14 \cdot 0.0017$ \\
\hline 16 & $=H 15 \cdot 0.0017$ \\
\hline 17 & $=H 16 \cdot 0.0017$ \\
\hline 18 & $=H 17 \cdot 0.0017$ \\
\hline 19 & $=-H 18 \cdot 0.0017$ \\
\hline 20 & $=H 19 \cdot 0.0017$ \\
\hline 21 & $=H 20 \cdot 0.0017$ \\
\hline 22 & $=H 21 \cdot 0.0017$ \\
\hline 23 & $-H 22 \cdot 0.0017$ \\
\hline 24 & $=H 23 \cdot 0.0017$ \\
\hline 25 & $-\mathrm{H} 24 \cdot 0.0017$ \\
\hline 26 & $=H 25 \cdot 0.0017$ \\
\hline 27 & $=\mathrm{H} 26-0.0017$ \\
\hline 28 & $=\mathrm{H} 27 \cdot 0.0017$ \\
\hline 29 & $=\left(21250^{\circ}(\mathrm{G} 28.0 .0017)+148750^{\circ}(\mathrm{H} 28.0 .0017)\right) / 170000$ \\
\hline 30 & $=\left(21250^{\circ}(G 29 \cdot 0.0017)+148750^{\circ}(\mathrm{H} 29 \cdot 0.0017)\right) / 170000$ \\
\hline 31 & $=\left(21250^{\circ}(G 30.0 .0017)+148750^{\circ}(H 30.0 .0017)\right) / 170000$ \\
\hline 32 & $=\left(21250^{\circ}(\mathrm{G} 31 \cdot 0.0017)+148750^{\circ}(\mathrm{H} 31 \cdot 0.0017)\right) / 170000$ \\
\hline 33 & $=\left(21250^{\circ}(G 32 \cdot 0.0017)+148750^{\circ}(H 32 \cdot 0.0017)\right) / 170000$ \\
\hline 34 & $=\left(21250^{\circ}(\mathrm{G} 33-0.0017)+148750^{\circ}(\mathrm{H} 33.0 .0017)\right) / 170000$ \\
\hline 35 & $=\left(21250^{\circ}(\mathrm{G} 34-0.0017)+148750^{\circ}(\mathrm{H} 34-0.0017)\right) / 170000$ \\
\hline 36 & $=\left(21250^{\circ}(\mathrm{G} 35 \cdot 0.0017)+148750^{\circ}(\mathrm{H} 35 \cdot 0.0017)\right) / 170000$ \\
\hline 37 & $=\left(21250^{\circ}(G 36-0.0017)+148750^{\circ}(H 36-0.0017)\right) / 170000$ \\
\hline 38 & $=\left(21250^{\circ}(\mathrm{G} 37 \cdot 0.0017)+148750^{\circ}(\mathrm{H} 37 \cdot 0.0017)\right) / 170000$ \\
\hline 39 & $=\left(21250^{\circ}(G 38.0 .0017)+148750^{\circ}(H 38-0.0017)\right) / 170000$ \\
\hline 40 & $=\left(21250^{\circ}(\mathrm{G} 39 \cdot 0.0017)+148750^{\circ}(\mathrm{H} 39-0.0017)\right) / 170000$ \\
\hline 41 & $=\left(21250^{\circ}(G 40.0 .0017)+148750^{\circ}(H 40.0 .0017)\right) / 170000$ \\
\hline 42 & $=\left(21250^{\circ}(G 41 \cdot 0.0017)+148750^{\circ}(H 41-0.0017)\right) / 170000$ \\
\hline 43 & $-\left(21250^{\circ}(G 42 \cdot 0.0017)+148750^{\circ}(H 42 \cdot 0.0017)\right) / 170000$ \\
\hline 44 & $=\left(21250^{\circ}(G 43.0 .0017)+148750^{\circ}(H 43-0.0017)\right) / 170000$ \\
\hline 45 & $=\left(21250^{\circ}(G 44-0.0017)+148750^{\circ}(\mathrm{H} 44-0.0017)\right) / 170000$ \\
\hline 46 & $=\left(21250^{\circ}(\mathrm{G} 45 \cdot 0.0017)+148750^{\circ}(\mathrm{H} 45-0.0017)\right) / 170000$ \\
\hline 47 & $=\left(21250^{\circ}(G 46.0 .0017)+148750^{\circ}(H 46.0 .0017)\right) / 170000$ \\
\hline
\end{tabular}




\begin{tabular}{|c|c|c|c|}
\hline & $\mathbf{E}$ & $\mathbf{F}$ & $\bar{G}$ \\
\hline 1 & & & NRF REACTOR SIZE STUDY CASE 7 \\
\hline 2 & & & Cs $-9.5 \mathrm{Ci} / \mathrm{Gal}$ (Min First 5 Yaars with $2 \mathrm{X}$ Satety Factor) \\
\hline 3 & & & NO2 Destruction Rate $=0.026$ M/Mon. \\
\hline 4 & & t & TK-49 Tomp. $-50^{\circ} \mathrm{C}$ \\
\hline 5 & & 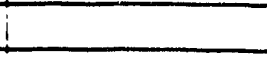 & TK-49 Sample Cycle a 3 Months \\
\hline 6 & & 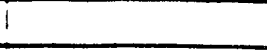 & TK.49 NO2 Range $=0.036$ TO $0.044 \mathrm{M}$ \\
\hline 7 & & $!$ & Process Rate $=42.500 \mathrm{Gal} / \mathrm{Mon}(75 \%$ of $\mathrm{BDR})$ \\
\hline 8 & & & 'NRF Reactors 2.200 .000 gallons \\
\hline 9 & & & \\
\hline 10 & TIME & TK 49 & NRF-1 \\
\hline 11 & DAYS & MNO2 & MNO2 \\
\hline 12 & 0 & 0.044 & 0.036 \\
\hline 13 & 15 & $=F 12 \cdot 0.0013$ & $=\mathrm{G} 12 \cdot 0.0013$ \\
\hline 14 & 30 & $=F 13-0.0013$ & $=G 13 \cdot 0.0013$ \\
\hline 15 & 45 & $F 14 \cdot 0.0013$ & $=G 14 \cdot 0.0013$ \\
\hline 16 & 60 & $-F 15-0.0013$ & $-G 15 \cdot 0.0013$ \\
\hline 17 & 75 & $=F 16 \cdot 0.0013$ & $=\mathrm{G} 16 \cdot 0.0013$ \\
\hline 18 & 90 & 0.044 & $=\mathrm{G} 17 \cdot 0.0013$ \\
\hline 19 & 105 & $-F 18.0 .0013$ & $=G 18-0.0013$ \\
\hline 20 & 120 & $-F 19 \cdot 0.0013$ & $=\mathrm{G} 19 \cdot 0.0013$ \\
\hline 21 & 135 & $-F 20.0 .0013$ & $=G 20 \cdot 0.0013$ \\
\hline 22 & 150 & $-F 21 \cdot 0.0013$ & $=G 21-0.0013$ \\
\hline 23 & 165 & $=F 22 \cdot 0.0013$ & $-G 22 \cdot 0.0013$ \\
\hline 24 & 180 & 0.044 & $=G 23-0.0013$ \\
\hline 25 & 195 & $=F 24 \cdot 0.0013$ & $=G 24 \cdot 0.0013$ \\
\hline 26 & 210 & $=F 25-0.0013$ & $=G 25 \cdot 0.0013$ \\
\hline 27 & 225 & $-F 26-0.0013$ & $=G 26 \cdot 0.0013$ \\
\hline 28 & 240 & $-F 27.0 .0013$ & $-G 27 \cdot 0.0013$ \\
\hline 29 & 255 & $=F 28 \cdot 0.0013$ & $=G 28 \cdot 0.0013$ \\
\hline 30 & 270 & 0.044 & $-G 29 \cdot 0.0013$ \\
\hline 31 & 285 & $=F 30 \cdot 0.0013$ & $-G 30 \cdot 0.0013$ \\
\hline 32 & 300 & $-F 31 \cdot 0.0013$ & $-\mathrm{G31} \cdot 0.0013$ \\
\hline 33 & 315 & $=F 32 \cdot 0.0013$ & $=\left(21250^{\circ}(F 32-0.0013)+178750^{\circ}(G 32-0.0013)\right) / 200000$ \\
\hline 34 & 330 & $-F 33 \cdot 0.0013$ & $=\left(21250^{\circ}(\mathrm{F} 33 \cdot 0.0013)+178750^{\circ}(\mathrm{G33} \cdot 0.0013)\right) / 200000$ \\
\hline 35 & 345 & $=F 34 \cdot 0.0013$ & $=\left(21250^{\circ}(\mathrm{F} 34 \cdot 0.0013)+178750^{\circ}(\mathrm{G} 34-0.0013)\right) / 200000$ \\
\hline 36 & 360 & 0.044 & $=\left(21250^{\circ}(\mathrm{F} 35 \cdot 0.0013)+178750^{\circ}(\mathrm{G} 35 \cdot 0.0013) / 200000\right.$ \\
\hline 37 & 375 & $-F 36-0.0013$ & $=\left(21250^{\circ}(\right.$ F 36-0.0013)+178750 $($ G36-0.0013) $) / 200000$ \\
\hline 38 & 390 & $=F 37-0.0013$ & $-\left(21250^{\circ}(\mathrm{F} 37 \cdot 0.0013)+178750^{\circ}(\mathrm{G} 37 \cdot 0.0013)\right) / 200000$ \\
\hline 39 & 405 & $=F 38 \cdot 0.0013$ & $=\left(21250^{\circ}(\mathrm{F} 38.0 .0013)+178750^{\circ}(\mathrm{G} 38.0 .0013)\right) / 200000$ \\
\hline 40 & 420 & $=F 39-0.0013$ & $=\left(21250^{\circ}(F 39-0.0013)+178750^{\circ}(\mathrm{G} 39 \cdot 0.0013)\right) / 200000$ \\
\hline 41 & 435 & $=F 40-0.0013$ & $=\left(21250^{\circ}(F 40.0 .0013)+178750^{\circ}(\mathrm{G} 40.0 .0013)\right) / 200000$ \\
\hline 42 & 450 & 0.044 & $=\left(21250^{\circ}(F 41-0.0013)+178750^{\circ}(G 41-0.0013)\right) / 200000$ \\
\hline 43 & 465 & $-F 42 \cdot 0.0013$ & $=\left(21250^{\circ}(\mathrm{F} 42 \cdot 0.0013)+178750^{\circ}(\mathrm{G} 42-0.0013)\right) / 200000$ \\
\hline 44 & 480 & $=F 43 \cdot 0.0013$ & $=\left(21250^{\circ}(F 43-0.0013)+178750^{\circ}(G 43 \cdot 0.0013)\right) / 200000$ \\
\hline 45 & 495 & $-F 44-0.0013$ & $=\left(21250^{\circ}(F 44-0.0013)+178750^{\circ}(G 44 \cdot 0.0013)\right) / 200000$ \\
\hline 46 & 510 & $=F 45-0.0013$ & $=\left(21250^{\circ}(\mathrm{F} 45-0.0013)+178750^{\circ}(\mathrm{G} 45 \cdot 0.0013)\right) / 200000$ \\
\hline 47 & 525 & $-F 46 \cdot 0.0013$ & $=\left(21250^{\circ}(F 46-0.0013)+178750^{\circ}(G 46-0.0013)\right) / 200000$ \\
\hline
\end{tabular}




\begin{tabular}{|c|c|}
\hline & $\mathrm{H}$ \\
\hline 1 & CASE 7 \\
\hline 2 & \\
\hline 3 & \\
\hline 4 & \\
\hline 5 & \\
\hline 6 & \\
\hline 7 & \\
\hline 8 & \\
\hline$\frac{9}{10}$ & NRF.2 \\
\hline 11 & MNO2 \\
\hline 12 & 0.036 \\
\hline 13 & $=H 12 \cdot 0.0013$ \\
\hline 14 & $=H 13 \cdot 0.0013$ \\
\hline 15 & $=H 14 \cdot 0.0013$ \\
\hline 16 & $=\mathrm{H} 15-0.0013$ \\
\hline 17 & $=\mathrm{H} 16 \cdot 0.0013$ \\
\hline 18 & $=H 17 \cdot 0.0013$ \\
\hline 19 & $=H 18 \cdot 0.0013$ \\
\hline 20 & $=\mathrm{H} 19.0 .0013$ \\
\hline 21 & $=\mathrm{H} 20.0 .0013$ \\
\hline 22 & $-H 21-0.0013$ \\
\hline 23 & $=H 22 \cdot 0.0013$ \\
\hline 24 & $=H 23-0.0013$ \\
\hline 25 & $=\mathrm{H} 24 \cdot 0.0013$ \\
\hline 26 & $=\mathrm{H} 25 \cdot 0.0013$ \\
\hline 27 & $=H 26-0.0013$ \\
\hline 28 & $=H 27 \cdot 0.0013$ \\
\hline 29 & $=H 28-0.0013$ \\
\hline 30 & $-H 29 \cdot 0.0013$ \\
\hline 31 & $=\mathrm{H} 30.0 .0013$ \\
\hline 32 & $=\mathrm{H} 31 \cdot 0.0013$ \\
\hline 33 & $=\left(21250^{\circ}(G 32-0.0013)+178750^{\circ}(H 32-0.0013)\right) / 200000$ \\
\hline 34 & $=\left(21250^{\circ}(G 33.0 .0013)+178750^{\circ}(H 33-0.0013)\right) / 200000$ \\
\hline 35 & $-\left(21250^{\circ}(G 34-0.0013)+178750^{\circ}(H 34-0.0013)\right) / 200000$ \\
\hline 36 & $=\left(21250^{\circ}(\mathrm{G} 35 \cdot 0.0013)+178750^{\circ}(\mathrm{H} 35 \cdot 0.0013)\right) / 200000$ \\
\hline 37 & $=\left(21250^{\circ}(G 36-0.0013)+178750^{\circ}(H 36-0.0013)\right) / 200000$ \\
\hline 38 & $=\left(21250^{\circ}(G 37-0.0013)+178750^{\circ}(H 37-0.0013)\right) / 200000$ \\
\hline 39 & $=\left(21250^{\circ}(G 38-0.0013)+178750^{\circ}(H 38-0.0013)\right) / 200000$ \\
\hline 40 & $=\left(21250^{\circ}(G 39 \cdot 0.0013)+178750^{\circ}(H 39-0.0013)\right) / 200000$ \\
\hline 41 & $=\left(21250^{\circ}(G 40.0 .0013)+178750^{\circ}(\mathrm{H} 40.0 .0013)\right) / 200000$ \\
\hline 42 & $=\left(21250^{\circ}(G 41-0.0013)+178750^{\circ}(H 41-0.0013)\right) / 200000$ \\
\hline 43 & $=\left(21250^{\circ}(G 42-0.0013)+178750^{\circ}(H 42-0.0013)\right) / 200000$ \\
\hline 44 & $=\left(21250^{\circ}(G 43.0 .0013)+178750^{\circ}(H 43-0.0013)\right) / 200000$ \\
\hline 45 & $=\left(21250^{\circ}(G 44-0.0013)+178750^{\circ}(\mathrm{H} 44-0.0013)\right) / 200000$ \\
\hline 46 & $=\left(21250^{\circ}(\mathrm{G} 45.0 .0013)+178750^{\circ}(\mathrm{H} 45.0 .0013)\right) / 200000$ \\
\hline 47 & $=\left(21250^{\circ}(G 46-0.0013)+178750^{\circ}(\mathrm{H} 46-0.0013)\right) / 200000$ \\
\hline
\end{tabular}




\begin{tabular}{|c|c|c|c|}
\hline & $E$ & $\mathbf{F}$ & $\mathbf{G}$ \\
\hline 1 & & & NRF REACTOR SIZE STUDY CASE 8 \\
\hline 2 & & & Cs - $36 \mathrm{Ci} / \mathrm{Gal}$ (Average all waste) \\
\hline 3 & & & NO2 Destruction Rate $=0.01 \mathrm{M} / \mathrm{Mon}$. \\
\hline 4 & & & TK-49 Temp. $=40^{\circ} \mathrm{C}$ \\
\hline 5 & & & TK-49 Sample Cycle $=3$ Months \\
\hline 6 & & & TK-49 NO2 Range $=0.029$ to $0.059 \mathrm{M}$ \\
\hline 7 & & $\perp$ & Process Rate $=42.500 \mathrm{Gal} / \mathrm{Mon}(75 \%$ of BDR) \\
\hline 8 & & & NRF Reactors $2 \cdot 80,000$ gallons \\
\hline 9 & & 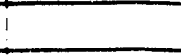 & 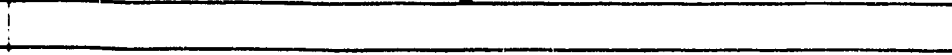 \\
\hline 10 & & & 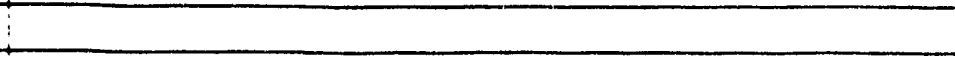 \\
\hline 11 & & & \\
\hline 12 & TIME & TANK49 & NRF-1 \\
\hline 13 & DAYS & MNO2 & MNO2 \\
\hline 14 & 0 & 0.059 & 0.029 \\
\hline 15 & 15 & 0.054 & 0.024 \\
\hline 16 & 30 & 0.049 & 0.019 \\
\hline 17 & 45 & 0.044 & 0.014 \\
\hline 18 & 60 & 0.039 & 0.011 \\
\hline 19 & 75 & 0.034 & $=\left(21250^{\circ}(F 18.0 .005)+58750^{\circ}(G 18.0 .005)\right) / 80000$ \\
\hline 20 & 90 & 0.059 & $=\left(21250^{\circ}(F 19 \cdot 0.005)+58750^{\circ}(\right.$ G 19-0.005) $) / 80000$ \\
\hline 21 & 105 & 0.054 & $=\left(21250^{\circ}(\mathrm{F} 20-0.005)+58750^{\circ}(\mathrm{G} 20-0.005)\right) / 80000$ \\
\hline 22 & 120 & 0.049 & $=\left(21250^{\circ}(\mathrm{F} 21-0.005)+58750^{\circ}(\mathrm{G} 21-0.005)\right) / 80000$ \\
\hline 23 & 135 & 0.044 & $=\left(21250^{\circ}(\mathrm{F} 22-0.005)+58750^{\circ}(\mathrm{G} 22 \cdot 0.005)\right) / 80000$ \\
\hline 24 & 150 & 0.039 & $=\left(21250^{\circ}(F 23-0.005)+58750^{\circ}(\right.$ G23-0.005) $) / 80000$ \\
\hline 25 & 165 & 0.034 & $=\left(21250^{\circ}(\mathrm{F} 24 \cdot 0.005)+58750^{\circ}(\mathrm{G} 24-0.005)\right) / 80000$ \\
\hline 26 & 180 & 0.059 & $=\left(21250^{\circ}(\mathrm{F} 25 \cdot 0.005)+58750^{\circ}(\mathrm{G} 25 \cdot 0.005)\right) / 80000$ \\
\hline 27 & 195 & 0.054 & $=\left(21250^{\circ}\left(\right.\right.$ F26-0.005) $+58750^{\circ}($ G26-0.005) $) / 80000$ \\
\hline 28 & 210 & 0.049 & $=\left(21250^{\circ}(F 27-0.005)+58750^{\circ}(G 27 \cdot 0.005)\right) / 80000$ \\
\hline 29 & 225 & 0.044 & $=\left(21250^{\circ}(F 28-0.005)+58750^{\circ}(G 28 \cdot 0.005)\right) / 80000$ \\
\hline 30 & 240 & 0.039 & $=\left(21250^{\circ}(F 29-0.005)+58750^{\circ}(G 29 \cdot 0.005)\right) / 80000$ \\
\hline 31 & 255 & 0.034 & $=\left(21250^{\circ}(F 30-0.005)+58750^{\circ}(G 30-0.005)\right) / 80000$ \\
\hline 32 & 270 & 0.059 & $=\left(21250^{\circ}(F 31-0.005)+58750^{\circ}(\mathrm{G} 31-0.005)\right) / 80000$ \\
\hline 33 & 285 & 0.054 & $-\left(21250^{\circ}\left(\right.\right.$ F32-0.005) $+58750^{\circ}($ G32-0.005) $) / 80000$ \\
\hline 34 & 300 & 0.049 & $-\left(21250^{\circ}\left(\right.\right.$ F33-0.005) $+58750^{\circ}($ G33-0.005) $) / 80000$ \\
\hline 35 & 315 & 0.044 & $-\left(21250^{\circ}(\mathrm{F} 34-0.005)+58750^{\circ}(\mathrm{G} 34-0.005)\right) / 80000$ \\
\hline 36 & 330 & 0.039 & $-\left(21250^{\circ}(\mathrm{F} 35-0.005)+58750^{\circ}(\mathrm{G} 35-0.005)\right) / 80000$ \\
\hline 37 & 345 & 0.034 & $=\left(21250^{\circ}(\mathrm{F} 36-0.005)+58750^{\circ}(\mathrm{G} 36-0.005)\right) / 80000$ \\
\hline 38 & 360 & 0.059 & $=\left(21250^{\circ}(\mathrm{F} 37-0.005)+58750^{\circ}(\mathrm{G} 37-0.005)\right) / 80000$ \\
\hline 39 & 375 & 0.054 & $=\left(21250^{\circ}(\mathrm{F} 38.0 .005)+58750^{\circ}(\mathrm{G} 38.0 .005)\right) / 80000$ \\
\hline 40 & 390 & 0.049 & $=\left(21250^{\circ}(F 39-0.005)+58750^{\circ}(\mathrm{G} 39-0.005)\right) / 80000$ \\
\hline 41 & 405 & 0.044 & $=\left(21250^{\circ}(\mathrm{F} 40.0 .005)+58750^{\circ}(\mathrm{G} 40.0 .005)\right) / 80000$ \\
\hline 42 & 420 & 0.039 & $=\left(21250^{\circ}(F 41 \cdot 0.005)+58750^{\circ}(G 41 \cdot 0.005)\right) / 80000$ \\
\hline 43 & & 0.034 & $=\left(21250^{\circ}(F 42-0.005)+58750^{\circ}(G 42-0.005)\right) / 80000$ \\
\hline
\end{tabular}




\begin{tabular}{|c|c|}
\hline & $\mathbf{H}$ \\
\hline 1 & CASE 8 \\
\hline 2 & \\
\hline 3 & \\
\hline 4 & \\
\hline 5 & \\
\hline 6 & \\
\hline$\frac{7}{8}$ & \\
\hline$\frac{\pi}{9}$ & \\
\hline 10 & \\
\hline 11 & \\
\hline 12 & NRF-2 \\
\hline 13 & MNO2 \\
\hline 14 & 0.029 \\
\hline 15 & 0.024 \\
\hline 16 & 0.019 \\
\hline 17 & 0.014 \\
\hline 18 & 0.011 \\
\hline 10 & $=\left(21250^{\circ}(\mathrm{G} 18.0 .005)+58750^{\circ}(\mathrm{H} 18.0 .005)\right) / 80000$ \\
\hline 20 & $-\left(21250^{\circ}(019-0.005)+58750^{\circ}(H 19-0.005)\right) / 80000$ \\
\hline 21 & $=\left(21250^{\circ}(\mathrm{G} 20-0.005)\right) / 80000$ \\
\hline 22 & $-\left(21250^{\circ}(G 21-0.005)\right) / 80000$ \\
\hline 23 & $=\left(21250^{\circ}(\mathrm{G} 22-0.005)\right) / 80000$ \\
\hline 24 & $-\left(21250^{\circ}(\mathrm{G} 23 \cdot 0.005)+58750^{\circ}(\mathrm{H} 23 \cdot 0.005)\right) / 80000$ \\
\hline 25 & $-\left(21250^{\circ}(\mathrm{G} 24-0.005)+58750^{\circ}(\mathrm{H} 24-0.005) / 80000\right.$ \\
\hline 26 & $-\left(21250^{\circ}(\mathrm{G} 25 \cdot 0.005)+58750^{\circ}(\mathrm{H} 25 \cdot 0.005)\right) / 80000$ \\
\hline 27 & $=\left(21250^{\circ}(G 26 \cdot 0.005)+58750^{\circ}(H 26 \cdot 0.005)\right) / 80000$ \\
\hline 28 & $-\left(21250^{\circ}(G 27.0 .005)+58750^{\circ}(H 27.0 .005)\right) / 80000$ \\
\hline 29 & $=\left(21250^{\circ}(\mathrm{G} 28-0.005)+58750^{\circ}(\mathrm{H} 28-0.205)\right) / 80000$ \\
\hline 30 & $-\left(21250^{\circ}(\mathrm{G} 29 \cdot 0.005)+58750^{\circ}(\mathrm{H} 29-0.005)\right) / 80000$ \\
\hline 31 & $-\left(21250^{\circ}(\mathrm{G} 30.0 .005)+58750^{\circ}(\mathrm{H} 30-0.005)\right) / 80000$ \\
\hline 32 & $-\left(21250^{\circ}(G 31-0.005)+58750^{\circ}(H 31-0.005)\right) / 80000$ \\
\hline 33 & $=\left(21250^{\circ}(G 32-0.005)+58750^{\circ}(H 32-0.005)\right) / 80000$ \\
\hline 34 & $=\left(21250^{\circ}(\mathrm{G} 33 \cdot 0.005)+58750^{\circ}(\mathrm{H} 33 \cdot 0.005)\right) / 80000$ \\
\hline 35 & $=\left(21250^{\circ}(\mathrm{G} 34-0.005)+58750^{\circ}(\mathrm{H} 34-0.005)\right) / 80000$ \\
\hline 36 & $=\left(21250^{\circ}(\mathrm{G} 35-0.005)+58750^{\circ}(\mathrm{H} 35-0.005)\right) / 80000$ \\
\hline 37 & $=\left(21250^{\circ}(\mathrm{G} 36-0.005)+58750^{\circ}(\mathrm{H} 36-0.005)\right) / 80000$ \\
\hline 38 & $=\left(21250^{\circ}(\mathrm{G} 37 \cdot 0.005)+58750^{\circ}(\mathrm{H} 37 \cdot 0.005)\right) / 80000$ \\
\hline 39 & $=\left(21250^{\circ}(\mathrm{G} 38-0.005)+58750^{\circ}(\mathrm{H} 38-0.005)\right) / 80000$ \\
\hline 40 & $=\left(21250^{\circ}(\mathrm{G} 39 \cdot 0.005)+58750^{\circ}(\mathrm{H} 39-0.005)\right) / 80000$ \\
\hline 41 & $=\left(21250^{\circ}(G 40.0 .005)+58750^{\circ}(\mathrm{H} 40.0 .005)\right) / 80000$ \\
\hline 42 & $=\left(21250^{\circ}(G 41-0.005)+58750^{\circ}(H 41-0.005)\right) / 80000$ \\
\hline 43 & $=\left(21250^{\circ}(G 42 \cdot 0.005)+58750^{\circ}(\mathrm{H} 42-0.005)\right) / 80000$ \\
\hline
\end{tabular}




\begin{tabular}{|c|c|c|c|}
\hline & E & $F$ & $\mathbf{G}$ \\
\hline 1 & & & INAF REACTOR SIZE STUDY CASE 9 \\
\hline 2 & & & Cs -36 CVGal (Average all waste) \\
\hline 3 & & $!$ & NO2 Destruction Rato 0.01 M/Mon. \\
\hline 4 & & & TK-49 Tomp. $=50^{\circ} \mathrm{C}$ \\
\hline 5 & & 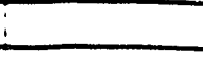 & TK-49 Sample Cycle - 1 Month \\
\hline 6 & & & TK-49 NO2 Ranoe $=0.036$ TO $0.046 \mathrm{M}$ \\
\hline 7 & & T & Process Rate $=42,500$ Gal/Mon ( $75 \%$ of BDR) \\
\hline 8 & & 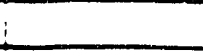 & NRF Reaciors $2.75,000$ gallons \\
\hline 9 & & & \\
\hline 10 & & 1 & \\
\hline 11 & & $i$ & \\
\hline 12 & TIME & TK 49 & NRF.1 \\
\hline 13 & DAYS & MNO2 & MNO2 \\
\hline 14 & Do & 0.046 & 0.036 \\
\hline 15 & 15 & 0.041 & 0.031 \\
\hline 16 & 30 & 0.046 & 0.026 \\
\hline 17 & 45 & 0.041 & 0.021 \\
\hline 18 & 60 & 0.046 & 0.016 \\
\hline 19 & 75 & 0.041 & 0.011 \\
\hline 20 & 90 & 0.046 & $-\left(21250^{\circ}(F 19-0.005)+53750^{\circ}\left(G_{19} 19.0 .005\right)\right) / 75000$ \\
\hline 21 & 105 & 0.041 & $-\left(21250^{\circ}(F 20.0 .005)+53750^{\circ}(\right.$ G20.0.005) $) / 75000$ \\
\hline 22 & 120 & 0.046 & $=\left(21250^{\circ}(F 21 \cdot 0.005)+53750^{\circ}(\mathrm{G} 21 \cdot 0.005)\right) / 75000$ \\
\hline 23 & 135 & 0.041 & $-\left(21250^{\circ}(F 22 \cdot 0.005)+53750^{\circ}(622 \cdot 0.005)\right) / 75000$ \\
\hline 24 & 150 & 0.046 & $-\left(21250^{\circ}(F 23-0.005)+53750^{\circ}(\right.$ G23.0.005) $) / 75000$ \\
\hline 25 & 165 & 0.041 & $=\left(21250^{\circ}(F 24-0.005)+53750^{\circ}(\right.$ G24-0.005) $/ 75000$ \\
\hline 26 & 180 & 0.046 & $=\left(21250^{\circ}\left(\right.\right.$ F25-0.005) $+53750^{\circ}($ G25-0.005) $) / 75000$ \\
\hline 27 & 195 & 0.041. & $=\left(21250^{\circ}(F 26-0.005)+53750^{\circ}(\right.$ G26-0.005) $/ 75000$ \\
\hline 28 & 210 & 0.046 & $=\left(21250^{\circ}(\mathrm{F} 27-0.005)+53750^{\circ}(\mathrm{G} 27-0.005)\right) / 75000$ \\
\hline 29 & 225 & 0.041 & $-\left(21250^{\circ}(F 28-0.005)+53750^{\circ}(\mathrm{G} 28.0 .005)\right) / 75000$ \\
\hline 30 & 240 & 0.046 & $-\left(21250^{\circ}(F 29-0.005)+53750^{\circ}(G 29-0.005)\right) / 75000$ \\
\hline 31 & 255 & 0.041 & $=\left(21250^{\circ}(\mathrm{F} 30.0 .005)+53750^{\circ}(\mathrm{G} 30.0 .005)\right) / 75000$ \\
\hline 32 & 270 & 0.046 & $-\left(21250^{\circ}(\mathrm{F31}-0.005)+53750^{\circ}(\mathrm{G31}-0.005)\right) / 75000$ \\
\hline 33 & 285 & 0.041 & $-\left(21250^{\circ}(F 32 \cdot 0.005)+53750^{\circ}(\right.$ G32-0.005))/75000 \\
\hline 34 & 300 & 0.046 & $=\left(21250^{\circ}(\mathrm{F} 33.0 .005)+53750^{\circ}(\mathrm{G} 33.0 .005)\right) / 75000$ \\
\hline 35 & 315 & 0.041 & $-\left(21250^{\circ}(\mathrm{F} 34-0.005)+53750^{\circ}(\mathrm{G} 34 \cdot 0.005)\right) / 75000$ \\
\hline 36 & 330 & 0.046 & $=\left(21250^{\circ}(\mathrm{F} 35.0 .005)+53750^{\circ}(\mathrm{G} 35.0 .005)\right) / 75000$ \\
\hline 37 & 345 & 0.041 & $-\left(21250^{\circ}(\right.$ F36-0.005)+53750*(G36-0.005))/75000 \\
\hline 38 & 360 & 0.046 & $-\left(21250^{\circ}(\right.$ F 37.0 .005$\left.)+53750^{\circ}(\mathrm{G} 37.0 .005)\right) / 75000$ \\
\hline 39 & 375 & 0.041 & $-\left(21250^{\circ}(F 38-0.005)+53750^{\circ}(G 38-0.005)\right) / 75000$ \\
\hline 40 & 390 & 0.046 & $=\left(21250^{\circ}(F 39-0.005)+53750^{\circ}(\mathrm{G} 39 \cdot 0.005)\right) / 75000$ \\
\hline 41 & 405 & 0.041 & $=\left(21250^{\circ}(F 40.0 .005)+53750^{\circ}(\mathrm{G} 40.0 .005)\right) / 75000$ \\
\hline 42 & 420 & 0.046 & $=\left(21250^{\circ}(F 41-0.005)+53750^{\circ}(\mathrm{G} 41-0.005)\right) / 75000$ \\
\hline 43 & 435 & 0.041 & $=\left(21250^{\circ}(F 42-0.005)+53750^{\circ}(\mathrm{G} 42-0.005)\right) / 75000$ \\
\hline
\end{tabular}




\begin{tabular}{|c|c|}
\hline & $\mathbf{H}$ \\
\hline 1 & CASE 9 \\
\hline 2 & \\
\hline 3 & \\
\hline 4 & \\
\hline$\frac{5}{6}$ & \\
\hline 7 & \\
\hline 8 & \\
\hline 9 & \\
\hline 10 & \\
\hline 11 & \\
\hline 12 & NAF-2 \\
\hline 13 & MNO2 \\
\hline 14 & 0.036 \\
\hline 15 & 0.031 \\
\hline 16 & 0.026 \\
\hline 17 & 0.021 \\
\hline 18 & 0.016 \\
\hline 19 & 0.011 \\
\hline 20 & $=\left(21250^{\circ}(G 19 \cdot 0.005)+53750^{\circ}(H 19 \cdot 0.005)\right) / 75000$ \\
\hline 21 & $=\left(21250^{\circ}(G 20-0.005)+53750^{\circ}(\mathrm{H} 20.0 .005)\right) / 75000$ \\
\hline 22 & $-\left(21250^{\circ}(G 21 \cdot 0.005)\right) / 75000$ \\
\hline 23 & $=\left(21250^{\circ}(G 22 \cdot 0.005)\right) / 75000$ \\
\hline 24 & $=\left(21250^{\circ}(G 23.0 .005)\right) / 75000$ \\
\hline 25 & $=\left(21250^{\circ}(G 24 \cdot 0.005)\right) / 75000$ \\
\hline 26 & $=\left(21250^{\circ}(G 25 \cdot 0.005)\right) / 75000$ \\
\hline 27 & $=\left(21250^{\circ}\left(\mathrm{G} 26-(0.005)+53750^{\circ}(\mathrm{H} 26-0.005)\right) / 75000\right.$ \\
\hline 28 & $-\left(21250^{\circ}(G 27.0 .005)+53750^{\circ}(\mathrm{H} 27.0 .005)\right) / 75000$ \\
\hline 29 & $-\left(21250^{\circ}(\mathrm{G} 28-0.005)+53750^{\circ}(\mathrm{H} 28.0 .005)\right) / 75000$ \\
\hline 30 & $-\left(21250^{\circ}(G 29-0.005)+53750^{\circ}(H 29.0 .005)\right) / 75000$ \\
\hline 31 & $=\left(21250^{\circ}(G 30.0 .005)+53750^{\circ}(H 30.0 .005)\right) / 75000$ \\
\hline 32 & $-\left(21250^{\circ}(\mathrm{G} 31 \cdot 0.005)+53750^{\circ}(\mathrm{H} 31 \cdot 0.005)\right) / 75000$ \\
\hline 33 & $=\left(21250^{\circ}(\mathrm{G} 32.0 .005)+53750^{\circ}(\mathrm{H} 32.0 .005)\right) / 75000$ \\
\hline 34 & $=\left(21250^{\circ}(\mathrm{G} 33.0 .005)+53750^{\circ}(\mathrm{H} 33.0 .005)\right) / 75000$ \\
\hline 35 & $=\left(21250^{\circ}(\mathrm{G} 34-0.005)+53750^{\circ}(\mathrm{H} 34-0.005)\right) / 75000$ \\
\hline 36 & $-\left(21250^{\circ}(\mathrm{G} 35.0 .005)+53750^{\circ}(\mathrm{H} 35.0 .005)\right) / 75000$ \\
\hline 37 & $=\left(21250^{\circ}(\mathrm{G} 36-0.005)+53750^{\circ}(\mathrm{H} 36-0.005)\right) / 75000$ \\
\hline 38 & $-\left(21250^{\circ}(\mathrm{G} 37-0.005)+53750^{\circ}(\mathrm{H} 37-0.005)\right) / 75000$ \\
\hline 39 & $=\left(21250^{\circ}(\mathrm{G} 38.0 .005)+53750^{\circ}(\mathrm{H} 38.0 .005)\right) / 75000$ \\
\hline 40 & $-\left(21250^{\circ}(G 39-0.005)+53750^{\circ}(H 39 \cdot 0.005)\right) / 75000$ \\
\hline $41:$ & $=\left(21250^{\circ}(G 40.0 .005)+53750^{\circ}(H 40.0 .005)\right) / 75000$ \\
\hline 42 & $=\left(21250^{\circ}(G 41.0 .005)+53750^{\circ}(H 41.0 .005)\right) / 75000$ \\
\hline $43:$ & $=\left(21250^{\circ}(G 42-0.005)+53750^{\circ}(\mathrm{H} 42 \cdot 0.005)\right) / 75000$ \\
\hline
\end{tabular}




\begin{tabular}{|c|c|c|c|}
\hline & $E$ & $F$ & $\mathbf{G}$ \\
\hline 1 & & & NAF REACTOR SIZE STUDY CASE 10 \\
\hline 2 & & & Cs $=23.2$ Ci/Gal (Average First 5 Years) \\
\hline 3 & & & NO2 Destruction Rate= 0.064 MMMon. \\
\hline 4 & & & TK-49 Tomp. $=40^{\circ} \mathrm{C}$ \\
\hline 5 & & & TK-49 Sample Cycle $=1$ Months \\
\hline 6 & & & TK-49 NO2 Rarige $=0.029100 .0354 \mathrm{M}$ \\
\hline 7 & & & Process Rate $=42.500 \mathrm{Gal} / \mathrm{Mon}(75 \%$ of BDR) \\
\hline 8 & & 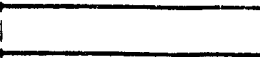 & WRF Reactors $2-80,000$ gallons \\
\hline 9 & & & \\
\hline 10 & & & \\
\hline 11 & & & \\
\hline 12 & & & \\
\hline 13 & TIME & TANK 49 & NRF-1 \\
\hline 14 & DAYS & MNO2 & MNO2 \\
\hline 16 & 0 & 0.0354 & 0.029 \\
\hline 17 & 15 & $-F 16 \cdot 0.0032$ & $=\mathrm{G} 16 \cdot 0.0032$ \\
\hline 18 & 30 & 0.0354 & $=G 17-0.0032$ \\
\hline 19 & 45 & $=F 18 \cdot 0.0032$ & $=\mathrm{G} 18-0.0032$ \\
\hline 20 & 60 & 0.0354 & $=\mathrm{G} 19 \cdot 0.0032$ \\
\hline 21 & 75 & $=F 20-0.0032$ & - G20.0.0032 \\
\hline 22 & 90 & 0.0354 & $=\left(21250^{\circ}\left(\right.\right.$ F21-0.0032) $+58750^{\circ}($ G21-0.0032) $) / 80000$ \\
\hline 23 & 105 & $=F 22-0.0032$ & $I=\left(21250^{\circ}\left(\right.\right.$ F22-0.0032) $+58750^{\circ}($ G22-0.0032) $) / 80000$ \\
\hline 24 & 120 & $0.0354 \cdots$ & $-\left(21250^{\circ}\left(\right.\right.$ F23-0.0032) $\left.+58750^{\circ}(\mathrm{G} 23-0.0032)\right) / 80000$ \\
\hline 25 & 135 & $=F 24-0.0032$ & $=\left(21250^{\circ}\left(\right.\right.$ F24-0.0032) $+58750^{\circ}($ G24-0.0032) $) / 80000$ \\
\hline 26 & 150 & 0.0354 & $=\left(21250^{\circ}(\mathrm{F} 25-0.0032)+58750^{\circ}(\mathrm{G} 25.0 .0032)\right) / 80000$ \\
\hline 27 & 165 & $-F 26-0.0032$ & $=\left(21250^{\circ}(\mathrm{F} 26-0.0032)+58750^{\circ}(\mathrm{Q} 26-0.0032)\right) / 80000$ \\
\hline 28 & 180 & 0.0354 & $=\left(21250^{\circ}\left(\right.\right.$ F27-0.0032) $\left.+58750^{\circ}(927-0.0032)\right) / 80000$ \\
\hline 29 & 195 & $-F 28 \cdot 0.0032$ & $=\left(21250^{\circ}(F 28-0.0032)+58750^{\circ}(\mathrm{G} 28-0.0032)\right) / 80000$ \\
\hline 30 & 210 & 0.0354 & $=\left(21250^{\circ}(F 29-0.0032)+58750^{\circ}(G 29-0.0032)\right) / 80000$ \\
\hline 31 & 225 & $-F 30 \cdot 0.0032$ & $-\left(21250^{\circ}(F 30-0.0032)+58750^{\circ}(G 30-0.0032)\right) / 80000$ \\
\hline 32 & 240 & 0.0354 & $=\left(21250^{\circ}(F 31-0.0032)+58750^{\circ}(G 31-0.0032)\right) / 80000$ \\
\hline 33 & 255 & $-F 32 \cdot 0.0032$ & $=\left(21250^{\circ}(\mathrm{F} 32-0.0032)+58750^{\circ}(\mathrm{G} 32-0.0032)\right) / 80000$ \\
\hline 34 & 270 & 0.0354 & $=\left(21250^{\circ}(\mathrm{F} 33-0.0032)+58750^{\circ}(\mathrm{G} 33-0.0032)\right) / 80000$ \\
\hline 35 & 285 & $=F 34 \cdot 0.0032$ & $=\left(21250^{\circ}(F 34-0.0032)+58750^{\circ}(\mathrm{G} 34-0.0032)\right) / 80000$ \\
\hline 36 & 300 & 0.0354 & $-\left(21250^{\circ}(F 35-0.0032)+58750^{\circ}(G 35-0.0032)\right) / 80000$ \\
\hline 37 & 315 & $-F 36-0.0032$ & $=\left(21250^{\circ}(\mathrm{F} 36-0.0032)+58750^{\circ}(\mathrm{G} 36-0.0032)\right) / 80000$ \\
\hline 38 & 330 & 0.0354 & $-\left(21250^{\circ}\left(\right.\right.$ F37-0.0032) $+58750^{\circ}($ G37-0.0032))/80000 \\
\hline 39 & 345 & $=F 38-0.0032$ & $=\left(21250^{\circ}(\mathrm{F} 38-0.0032)+58750^{\circ}(\mathrm{G} 38-0.0032)\right) / 80000$ \\
\hline 40 & 360 & 0.0354 & $=\left(21250^{\circ}\left(\right.\right.$ F39-0.0032) $+58750^{\circ}($ G39-0.0032) $) / 80000$ \\
\hline 41 & 375 & $-F 40-0.0032$ & $-\left(21250^{\circ}(F 40.0 .0032)+58750^{\circ}(G 40.0 .0032)\right) / 80000$ \\
\hline 42 & 390 & 0.0354 & $=\left(21250^{\circ}(F 41-0.0032)+58750^{\circ}(G 41-0.0032)\right) / 80000$ \\
\hline 43 & 405 & $=F 42 \cdot 0.0032$ & $=\left(21250^{\circ}(F 42-0.0032)+58750^{\circ}(G 42-0.0032)\right) / 80000$ \\
\hline 44 & 420 & 0.0354 & $=\left(21250^{\circ}(F 43-0.0032)+58750^{\circ}(G 43-0.0032)\right) / 80000$ \\
\hline 45 & 435 & $-F 44-0.0032$ & $=\left(21250^{\circ}(F 44-0.0032)+58750^{\circ}(G 44-0.0032)\right) / 80000$ \\
\hline 46 & 450 & 0.0354 & $=\left(21250^{\circ}(F 45-0.0032)+58750^{\circ}(G 45-0.0032)\right) / 80000$ \\
\hline 47 & & $=F 46-0.0032$ & $=\left(21250^{\circ}(F 46-0.0032)+58750^{\circ}(G 46-0.0032)\right) / 80000$ \\
\hline
\end{tabular}




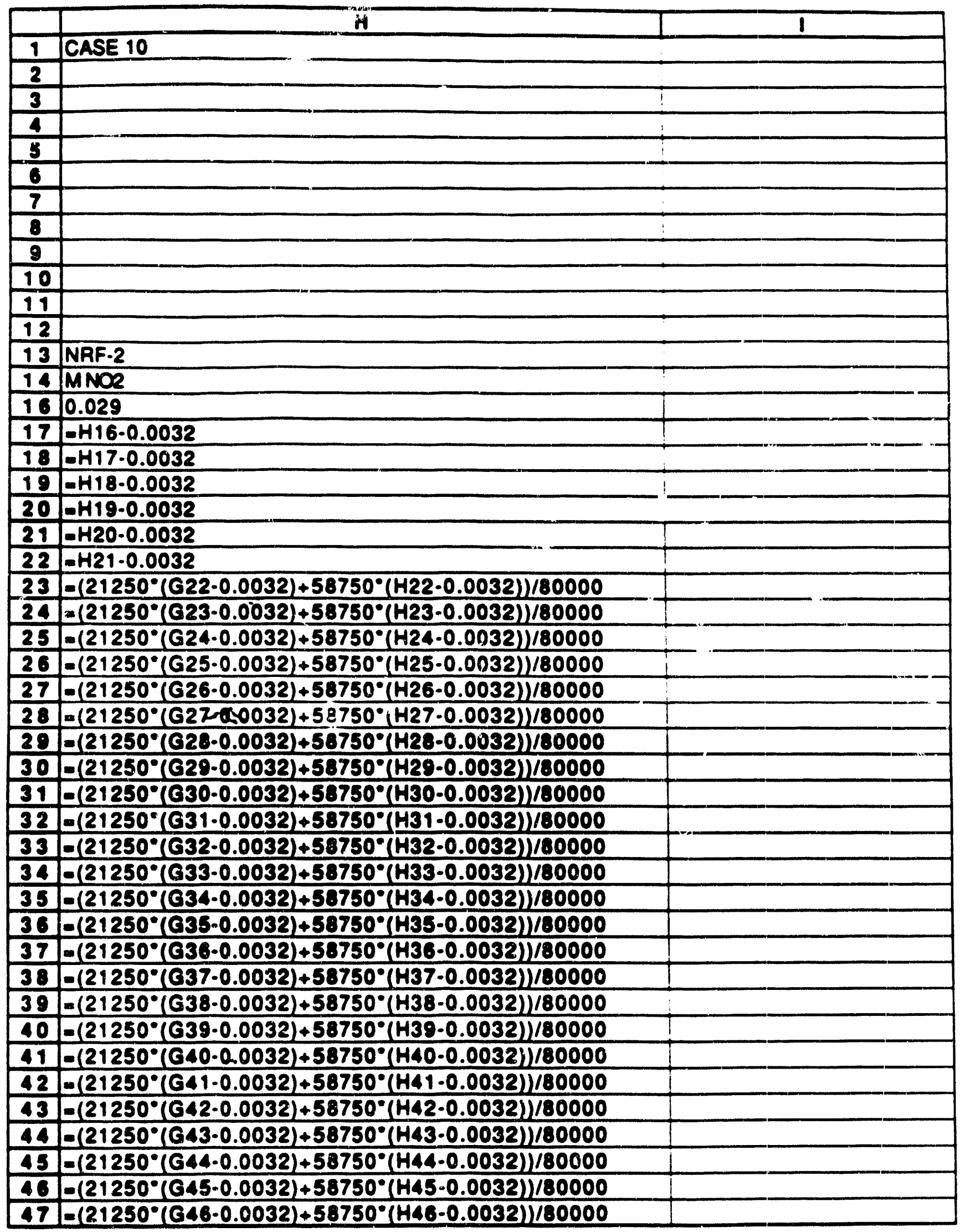


WSRC-TR-92-67

Revision 0

APPENDIX H. OVERHEAD SLIDES FROM TASK FORCE PRESENTATION

H-1

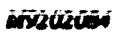



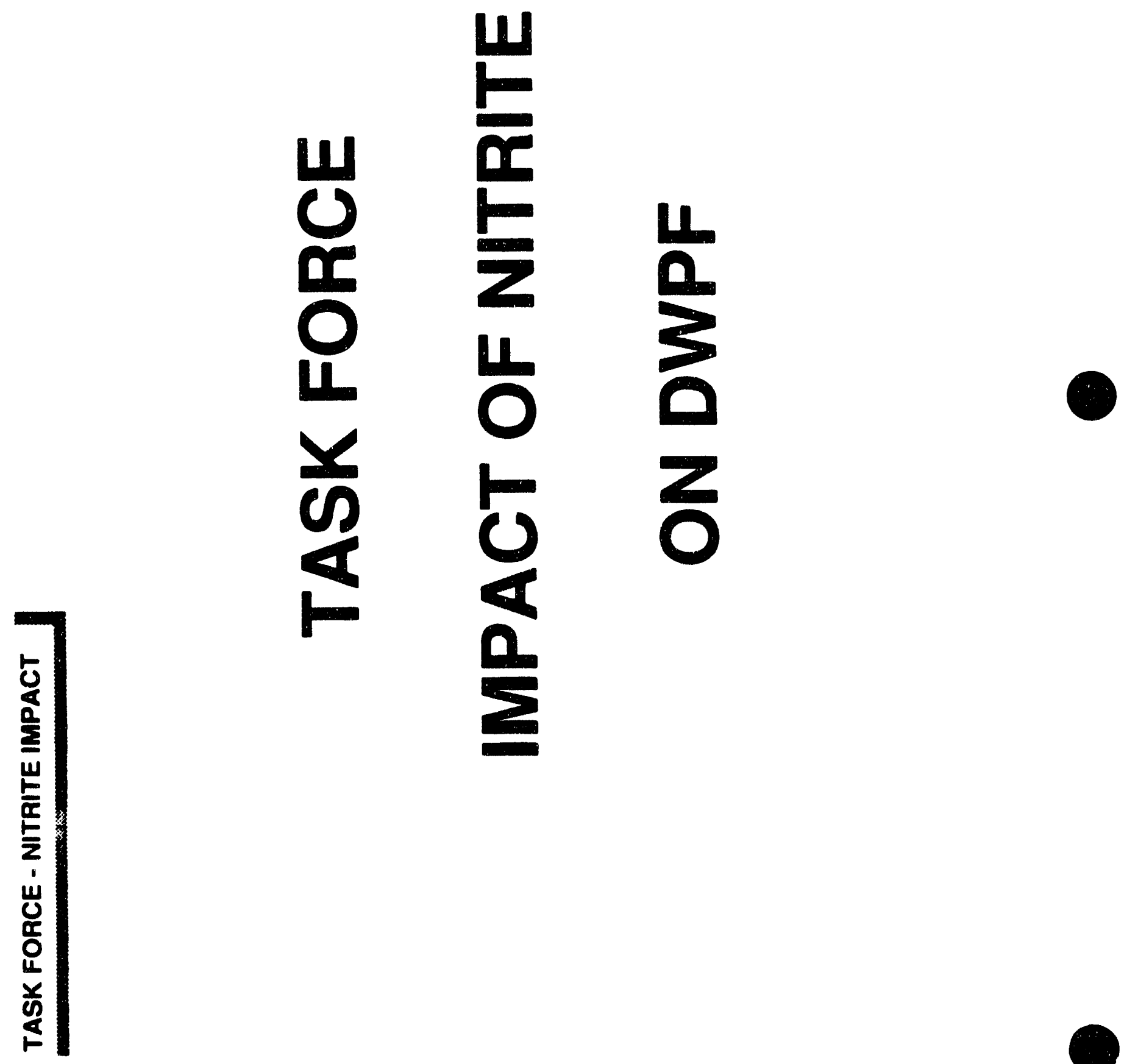
WSRC-TR-92-67

Revision 0

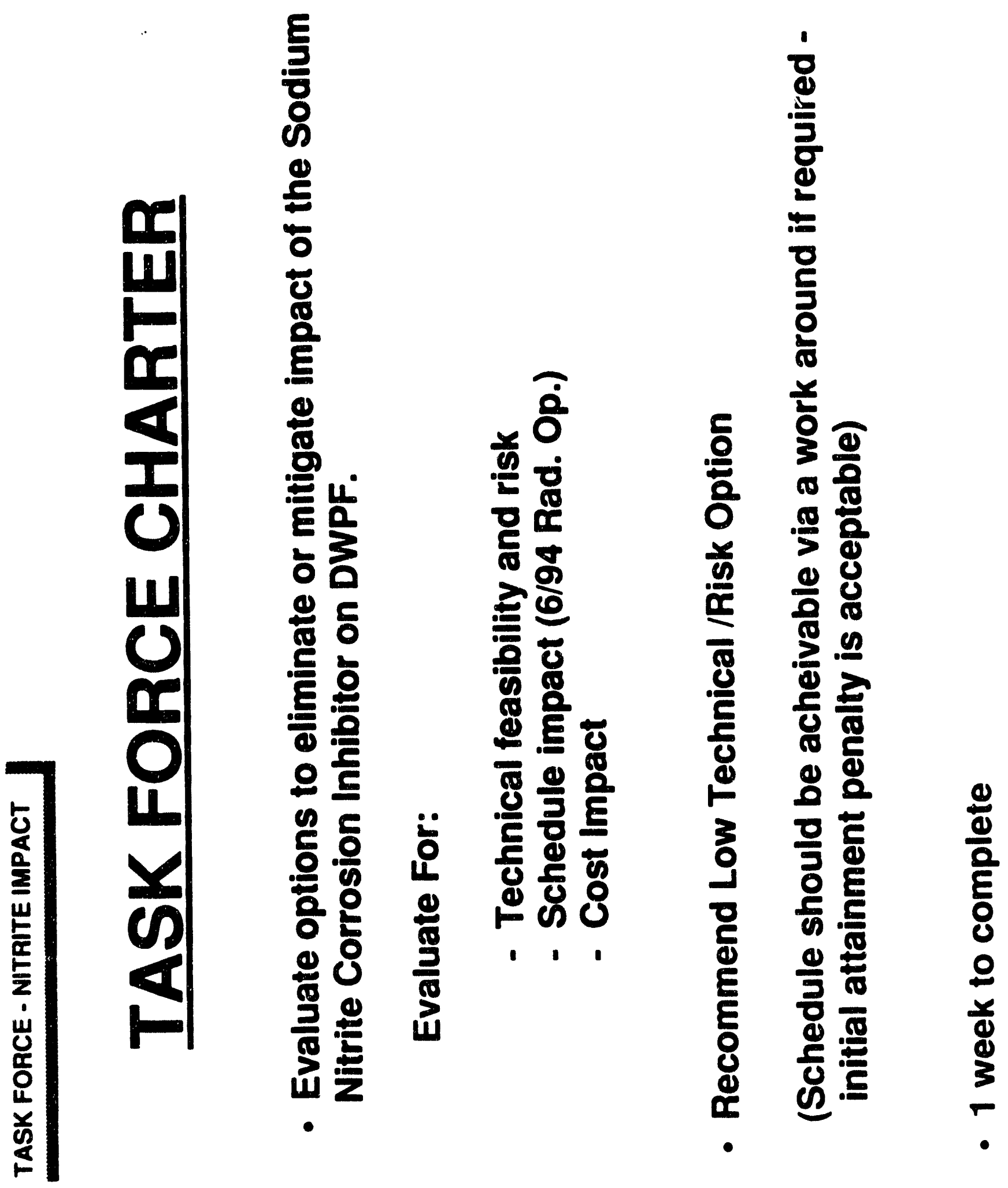




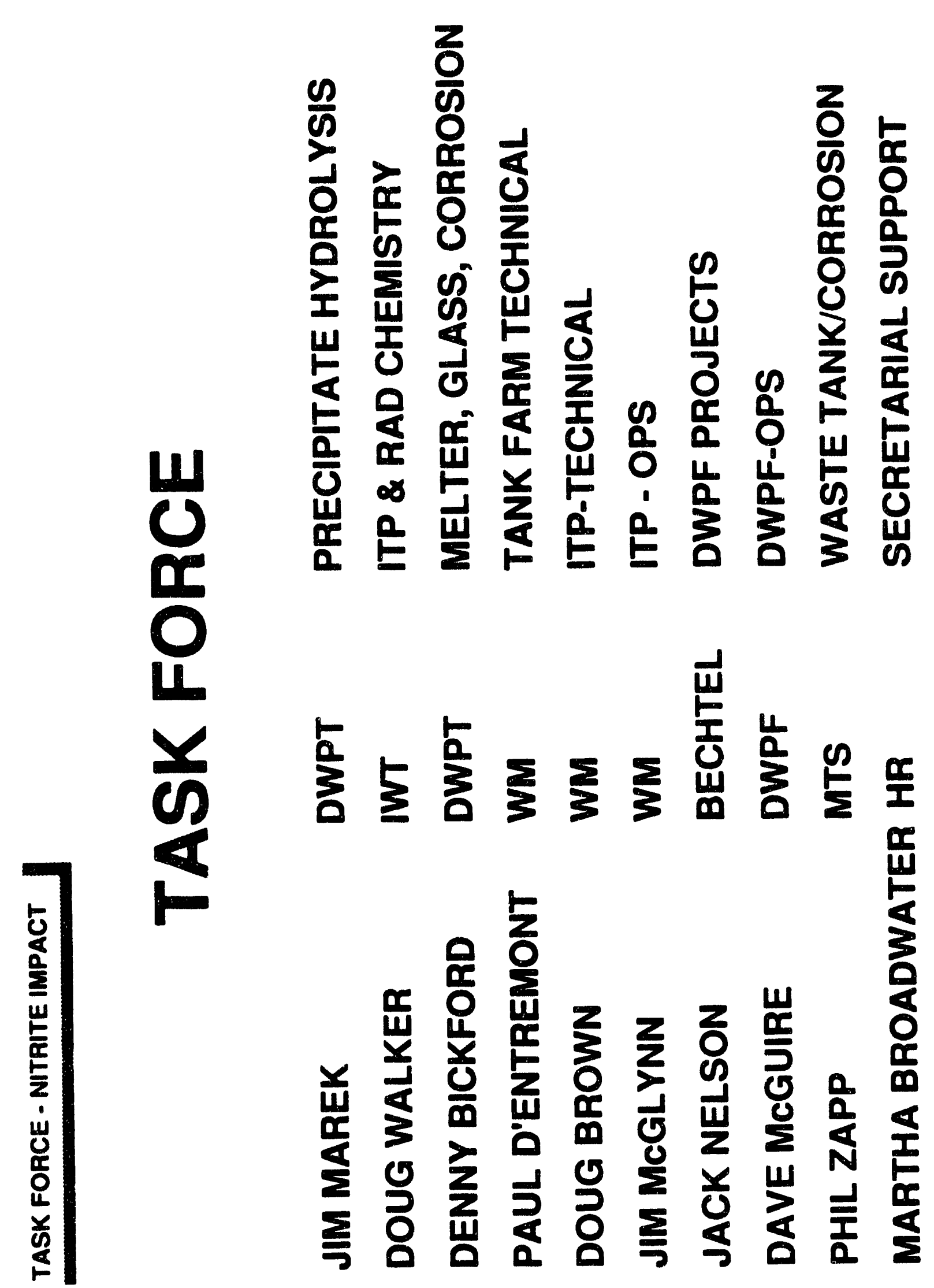


WSRC-TR-92-67

Revision 0

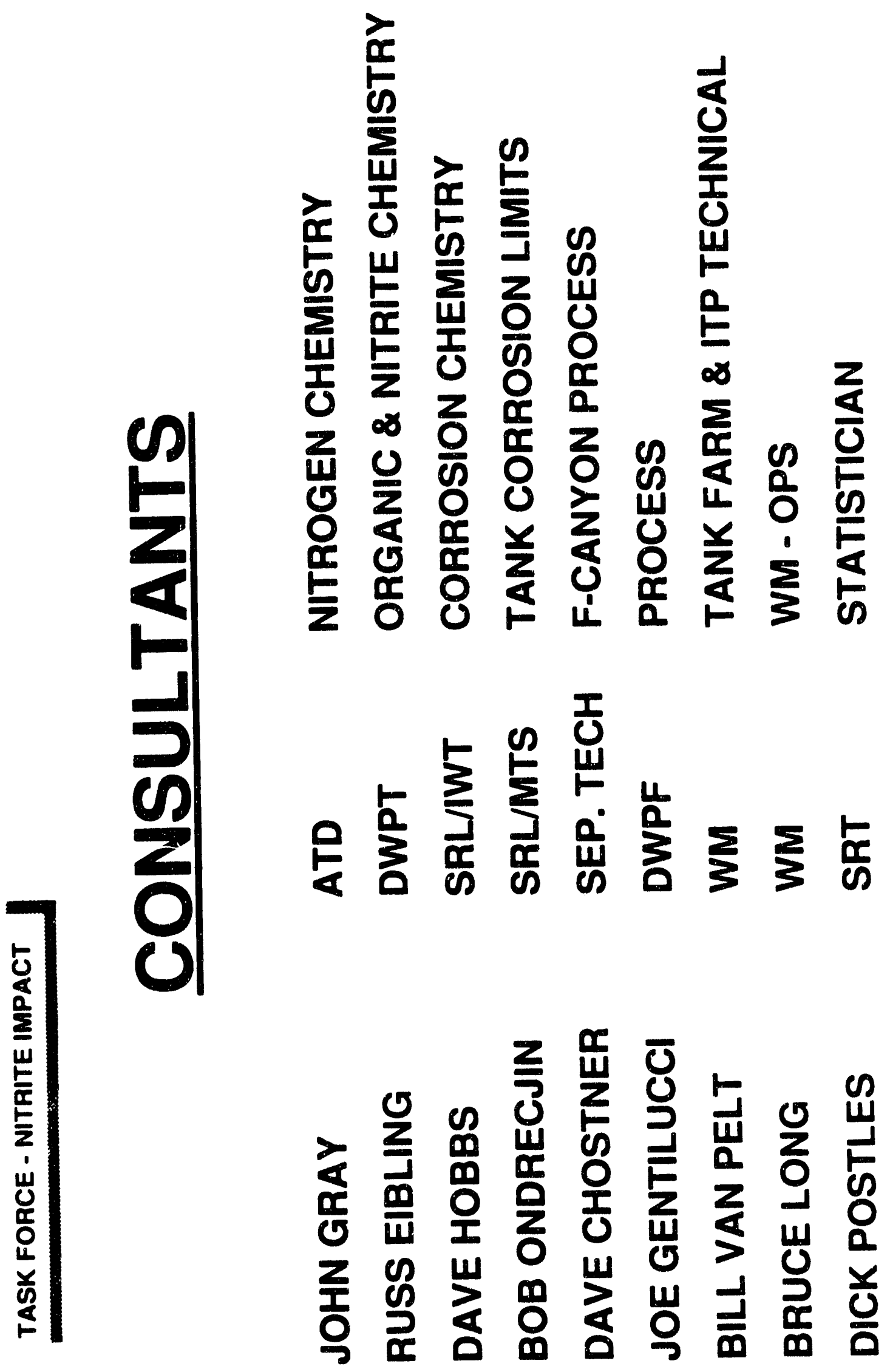



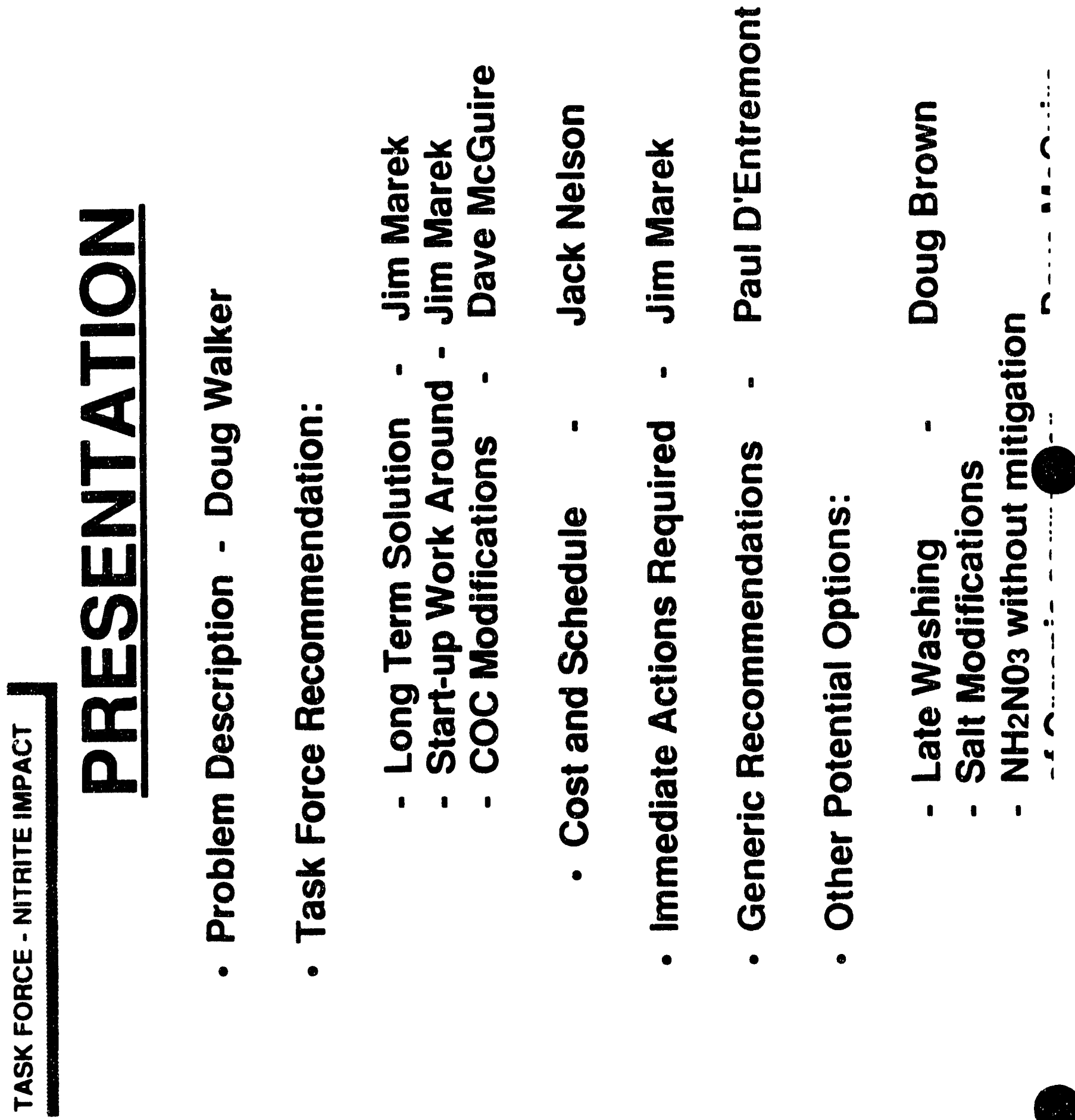


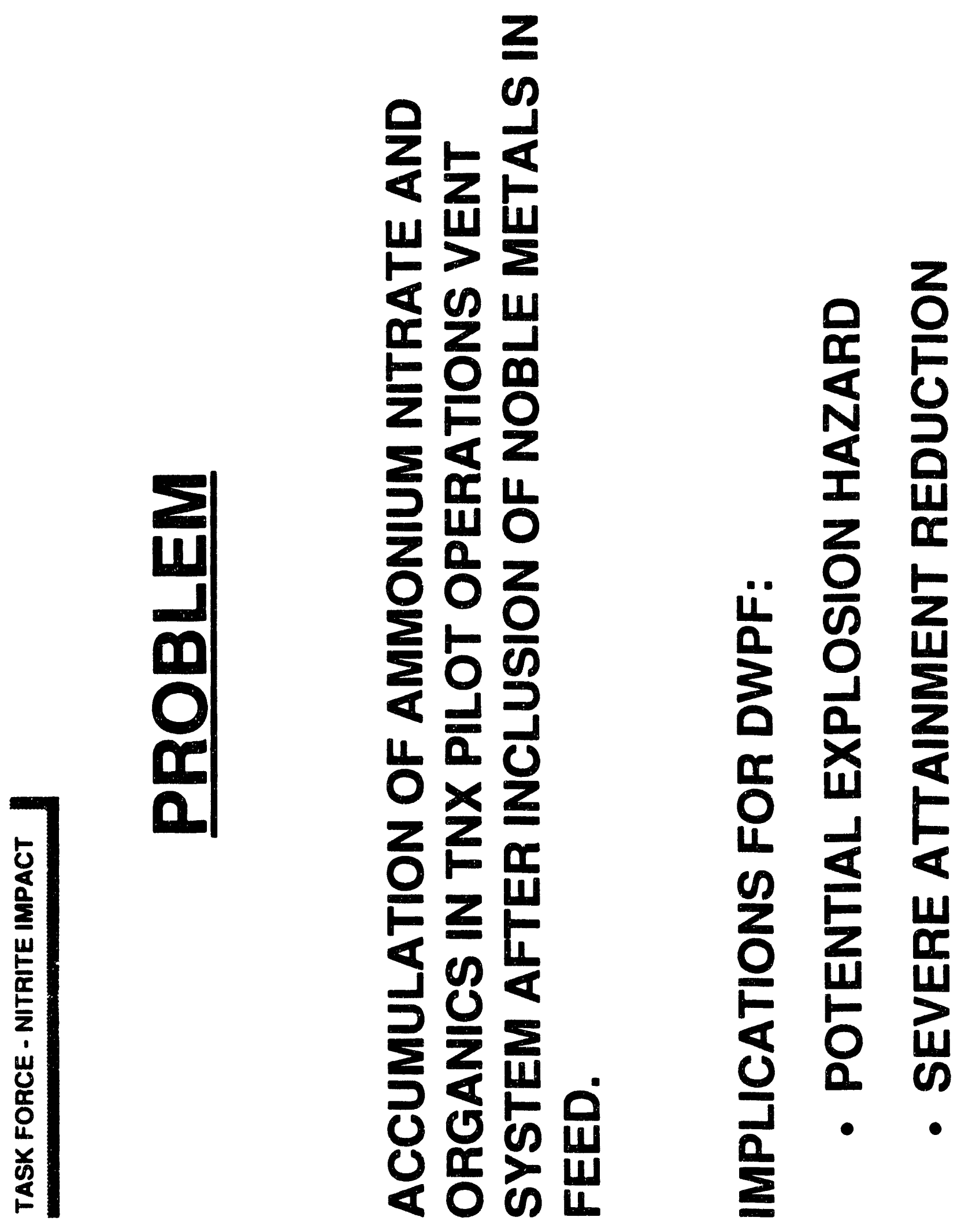




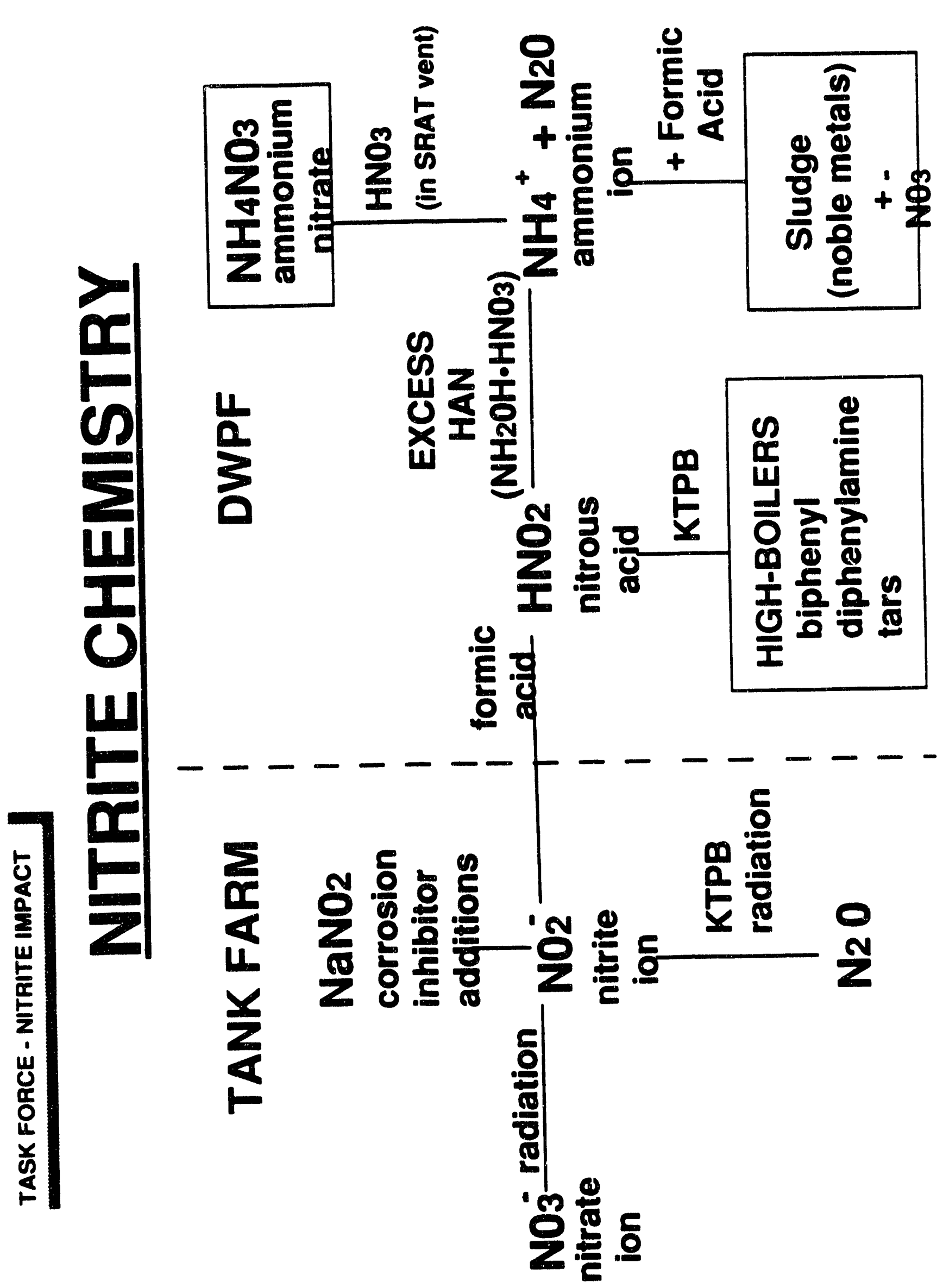


WSRC-TR-92-67

Revision 0

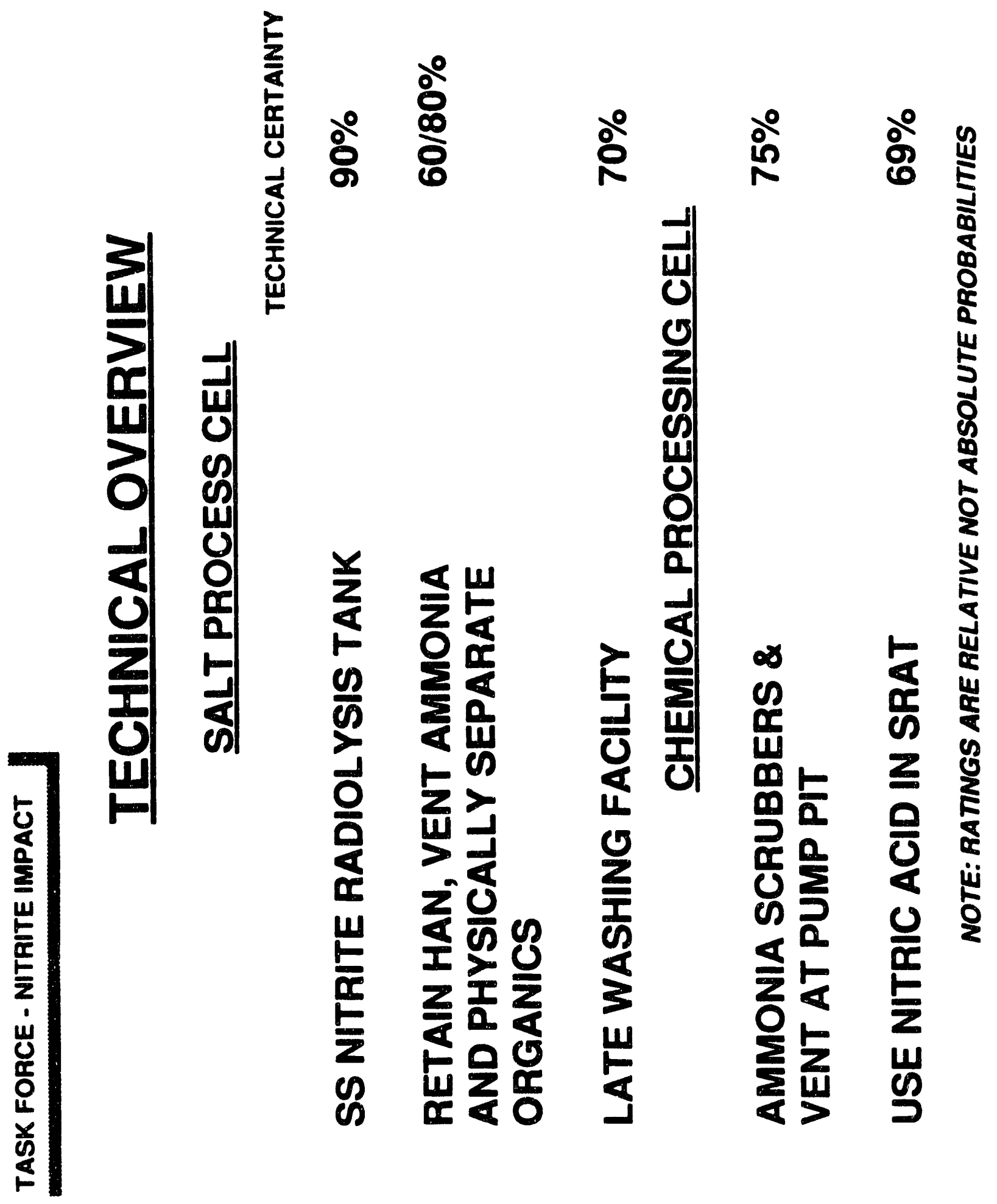



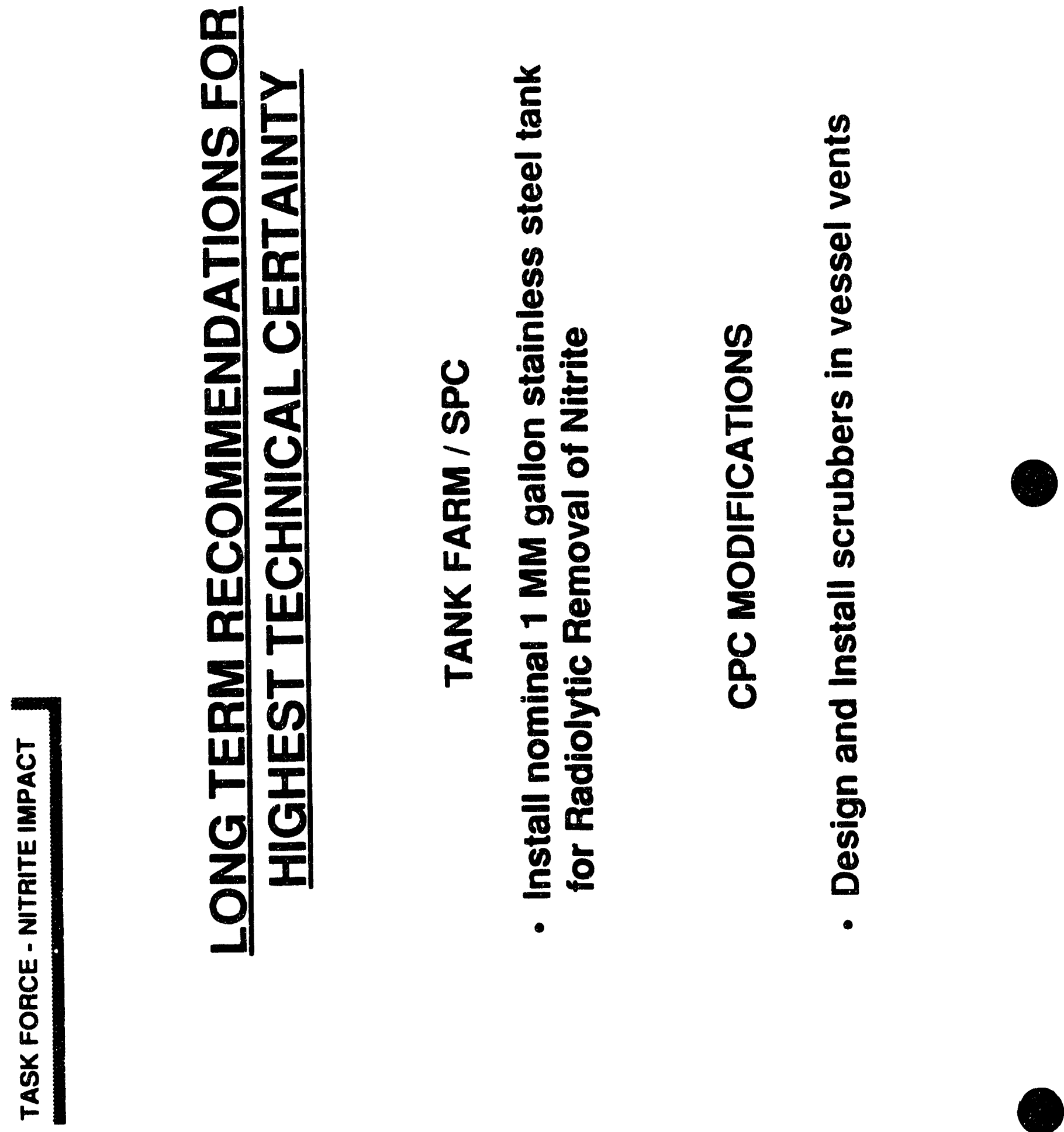
WSRC-TR-92-67

Revision 0

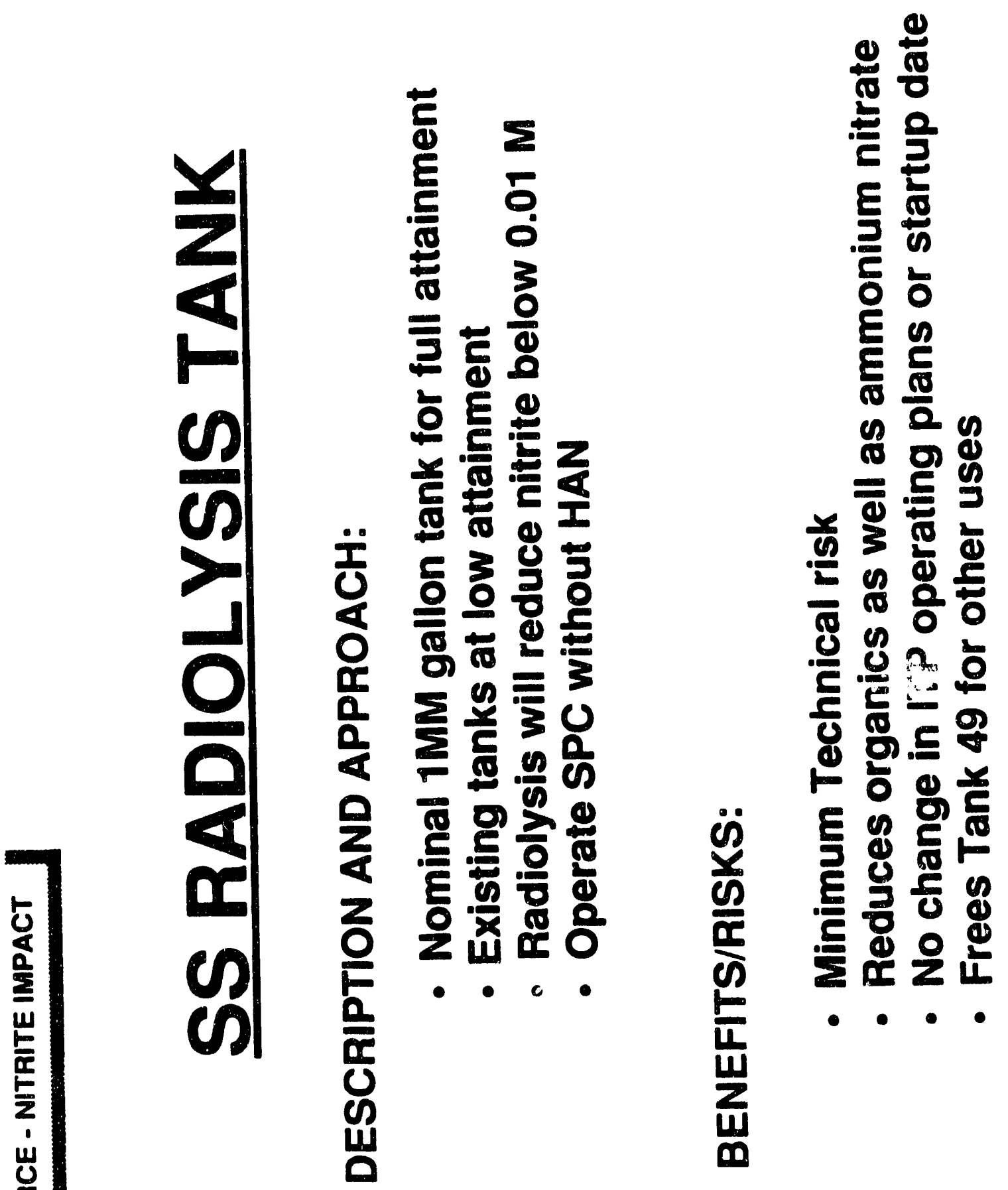



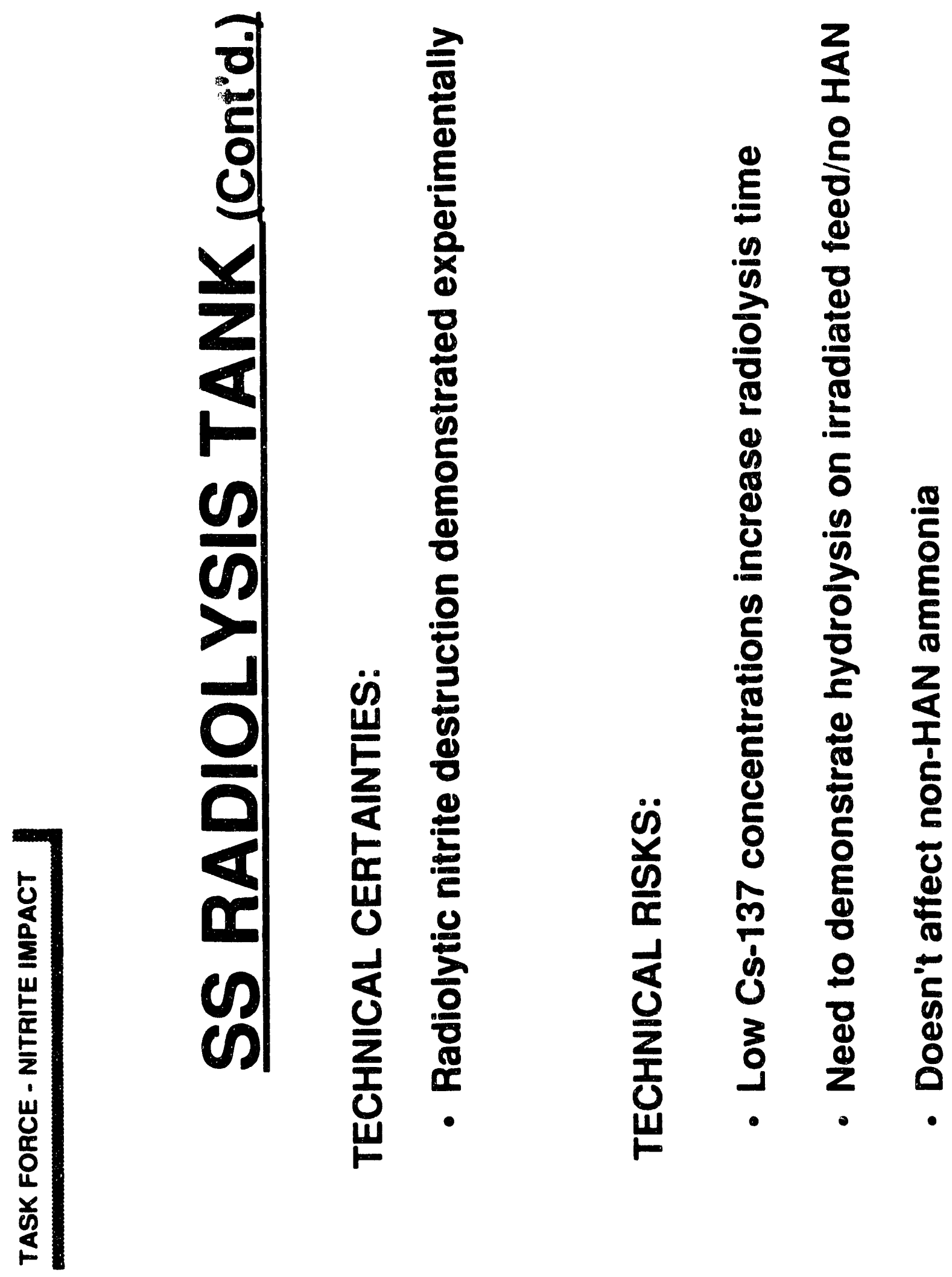

H-12 


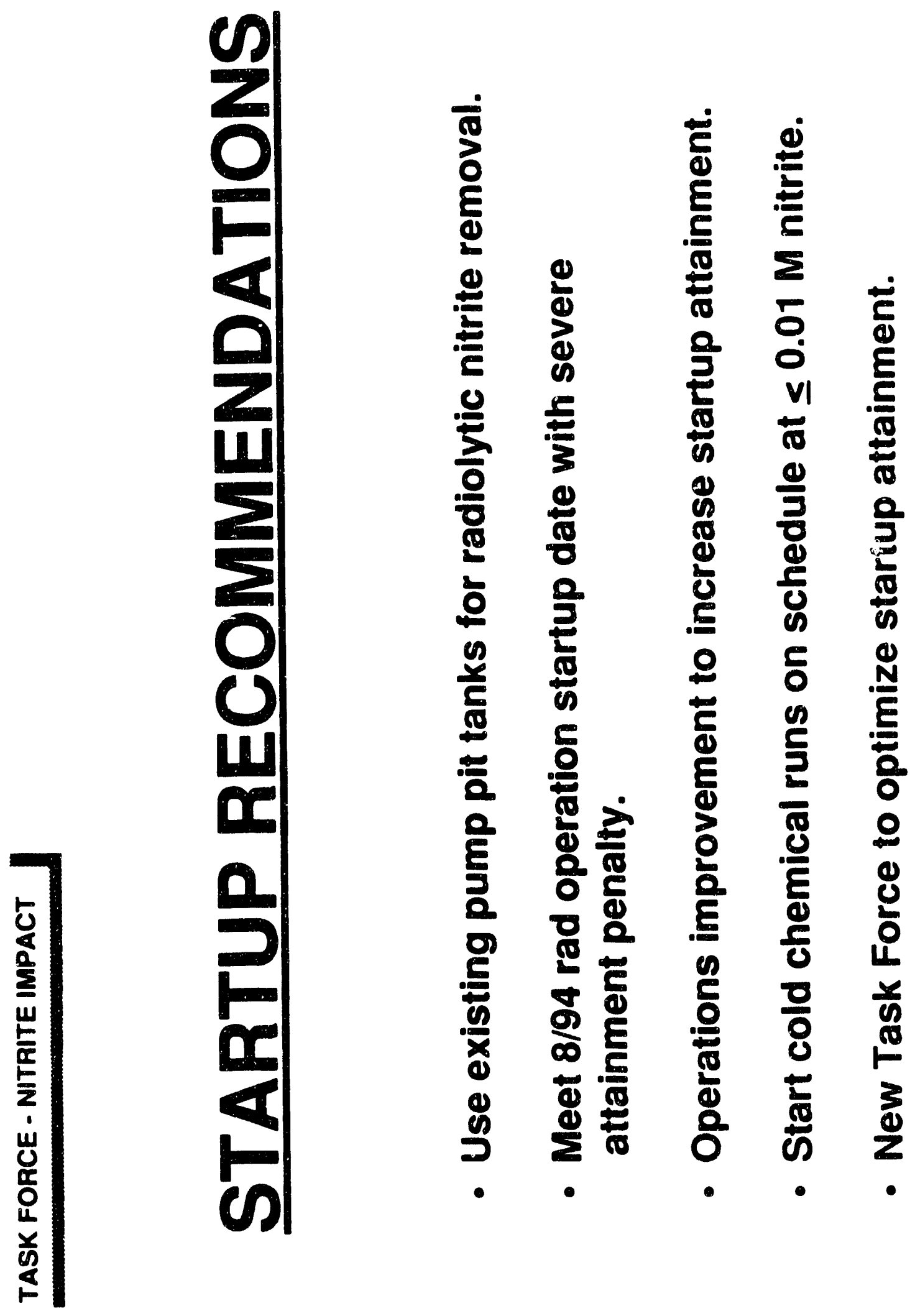



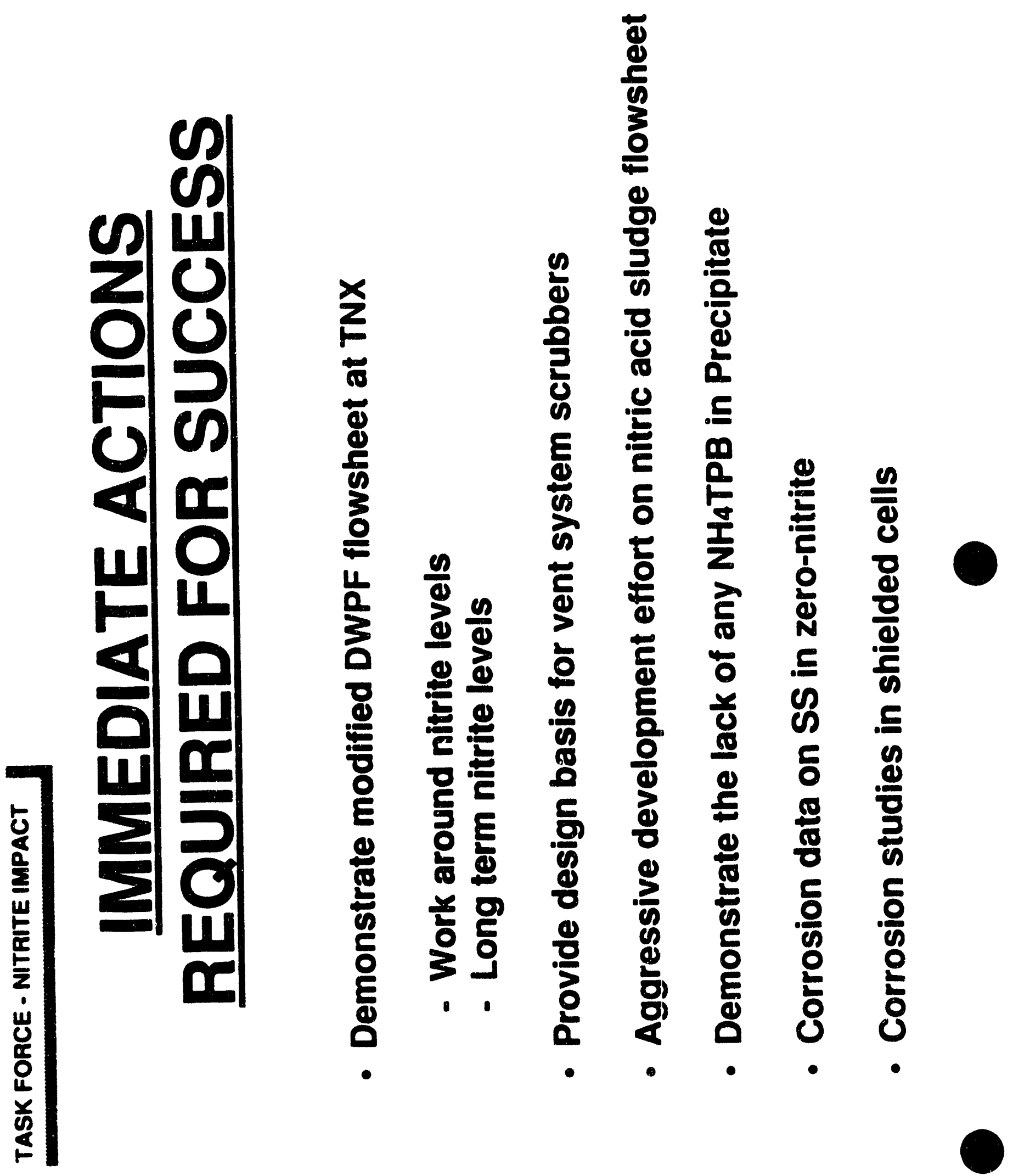


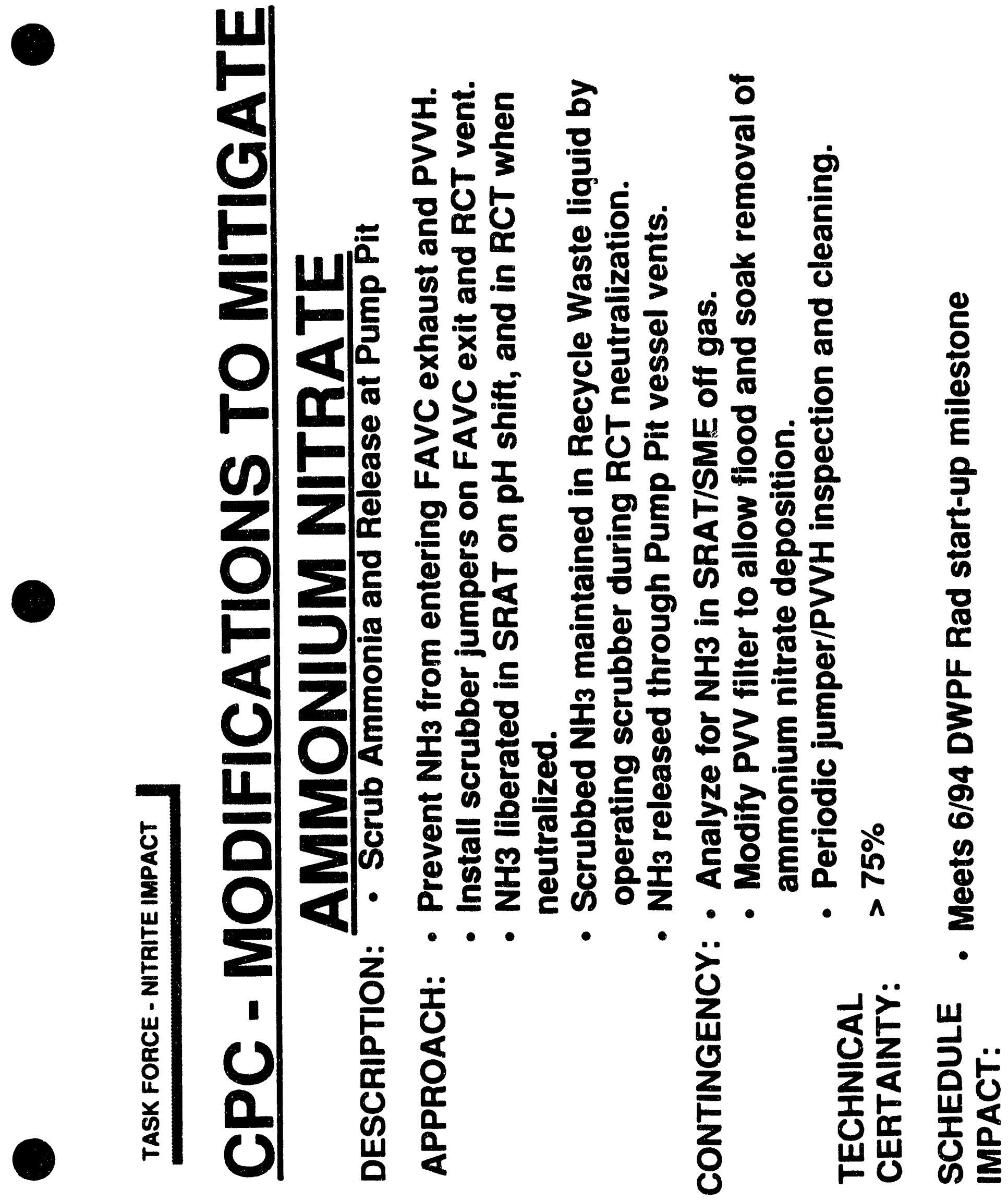



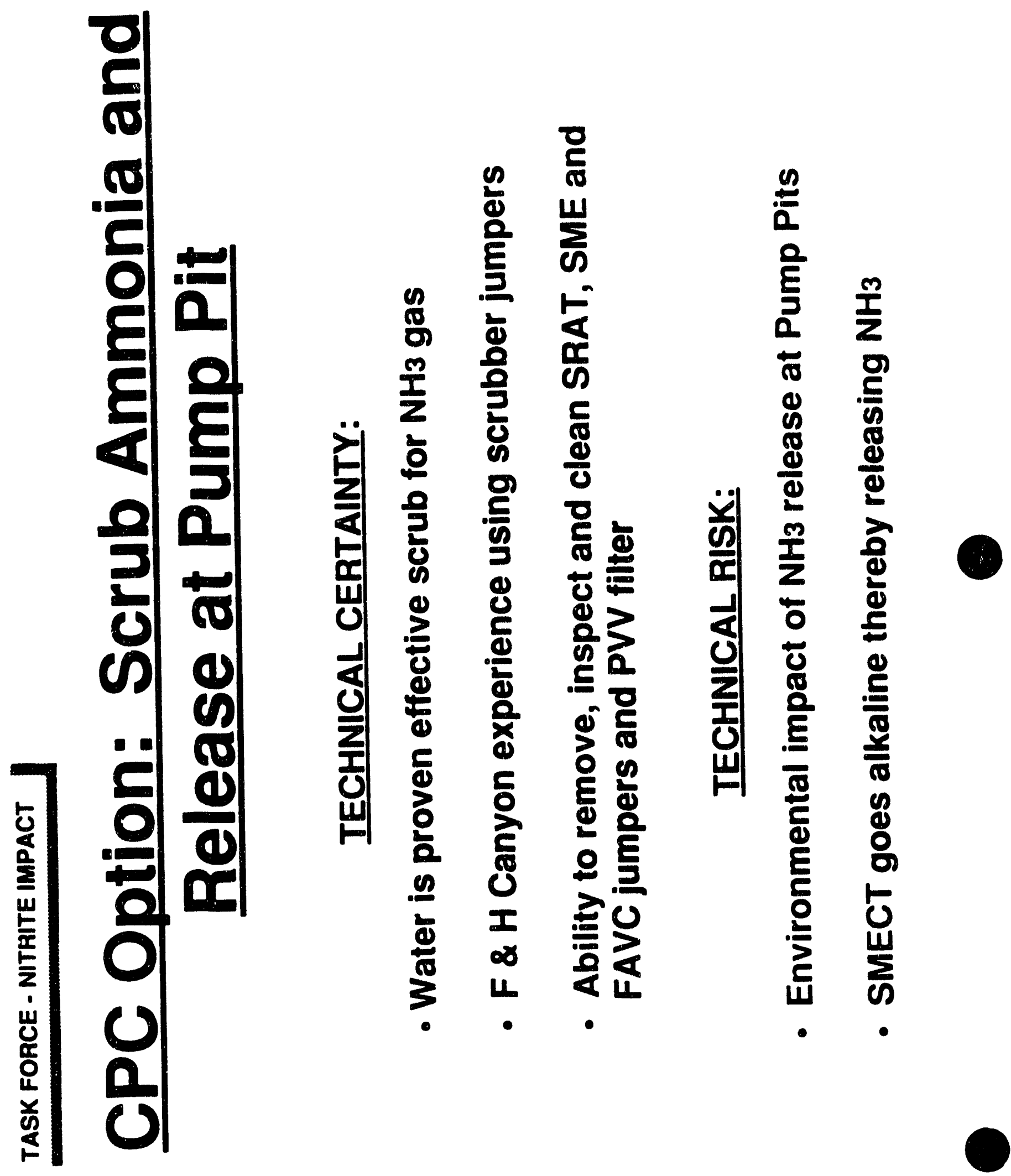
WSRC-TR-92-67

Revision 0

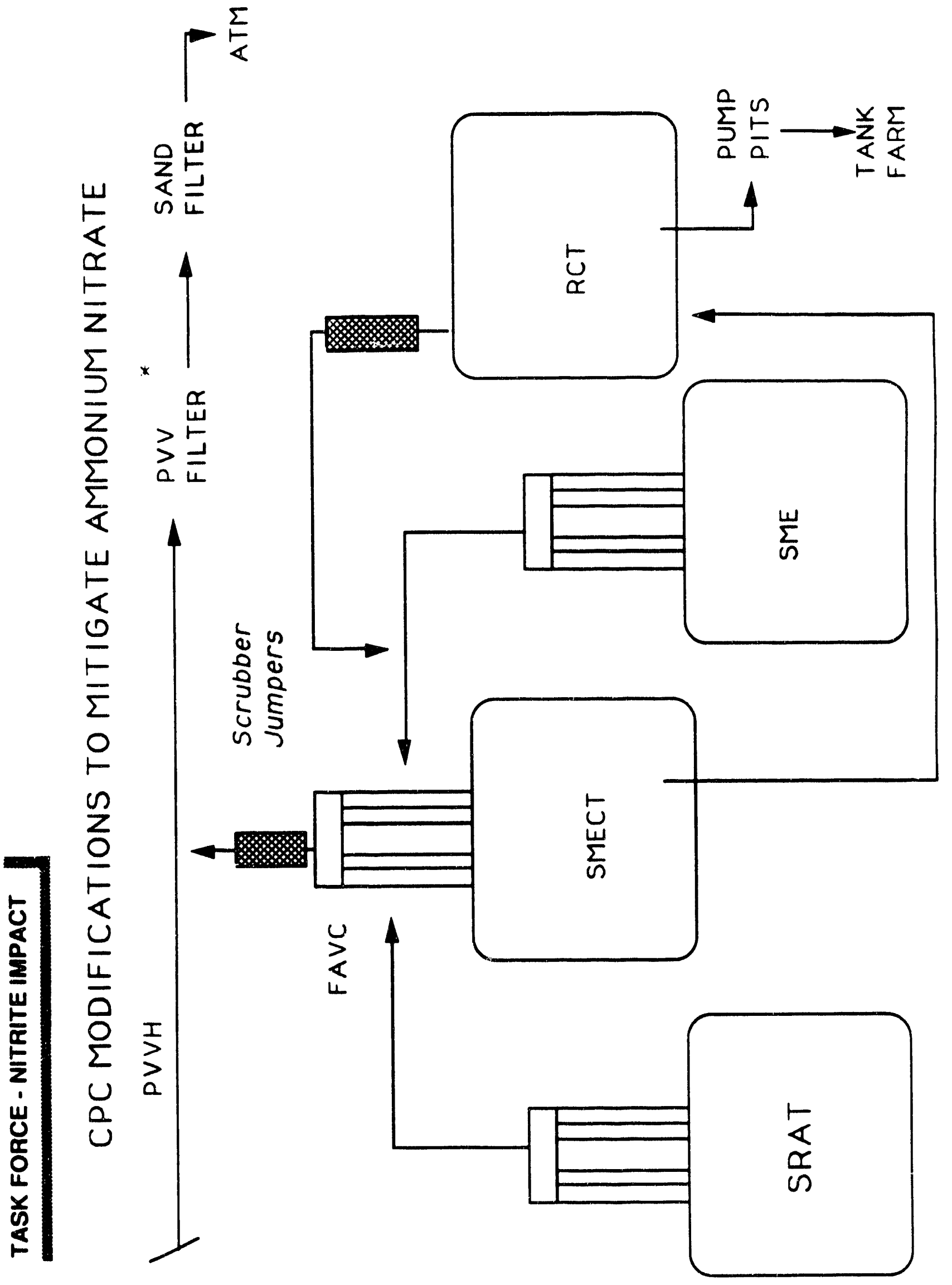




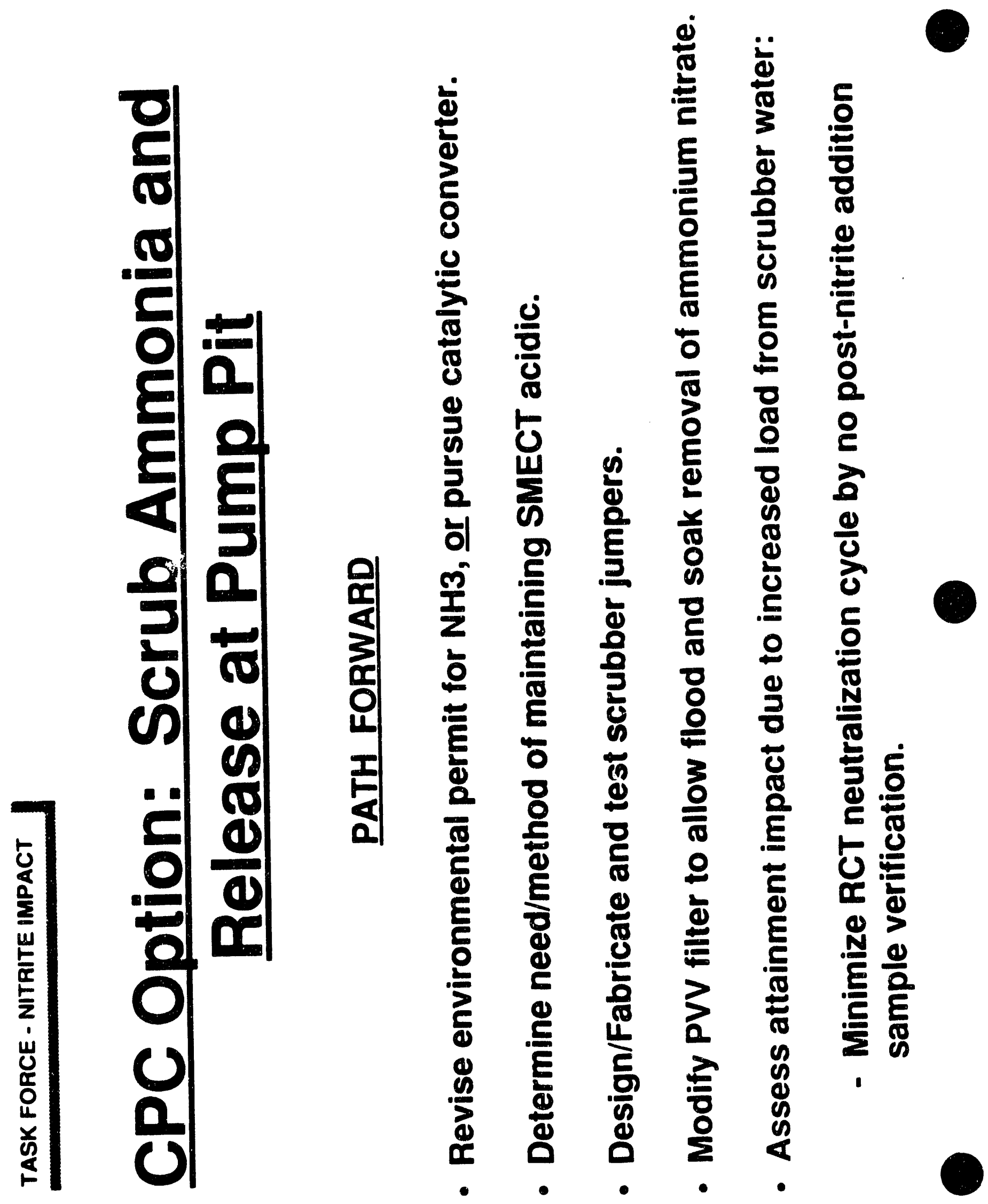




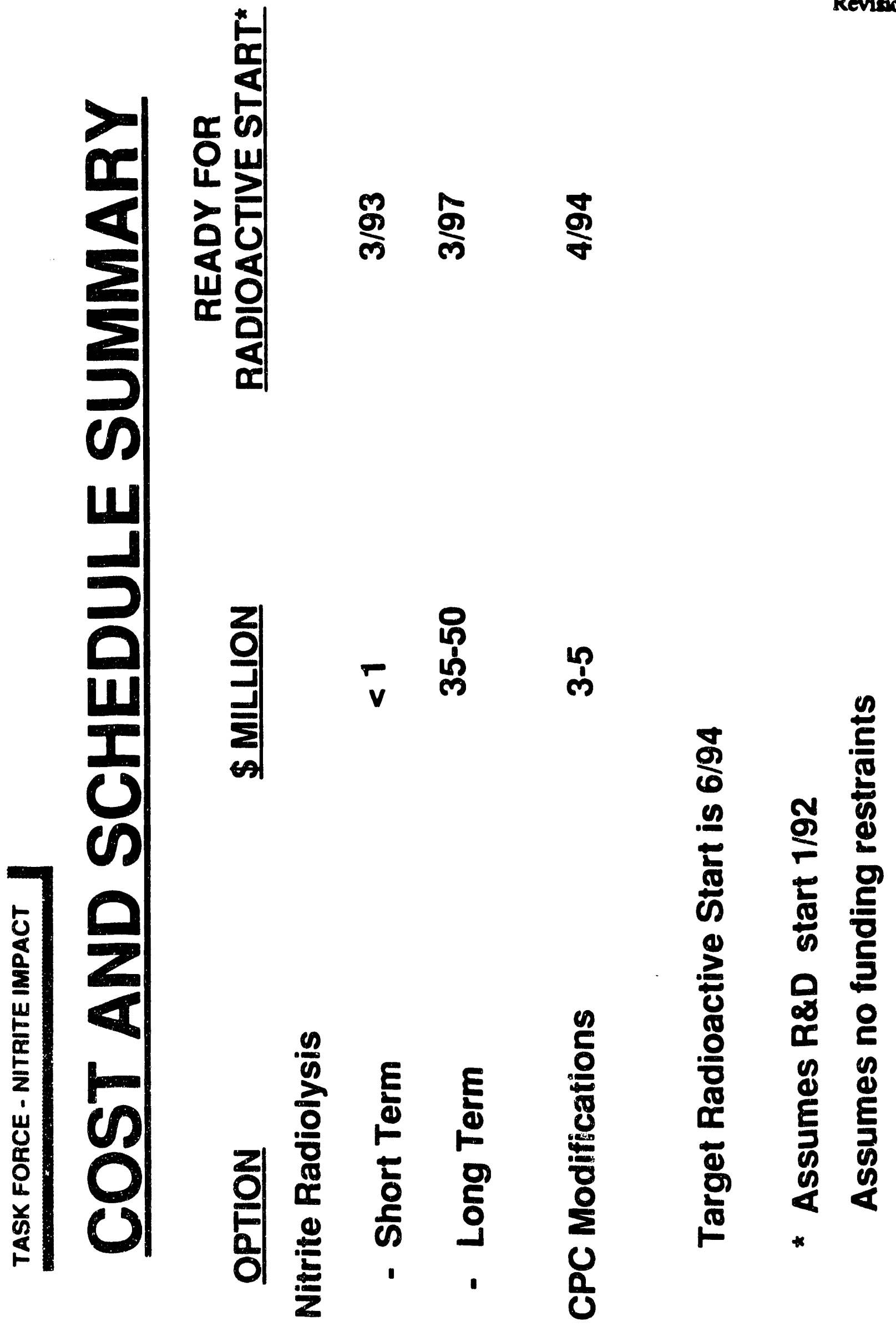


WSRC-TR-92-67

Revision 0

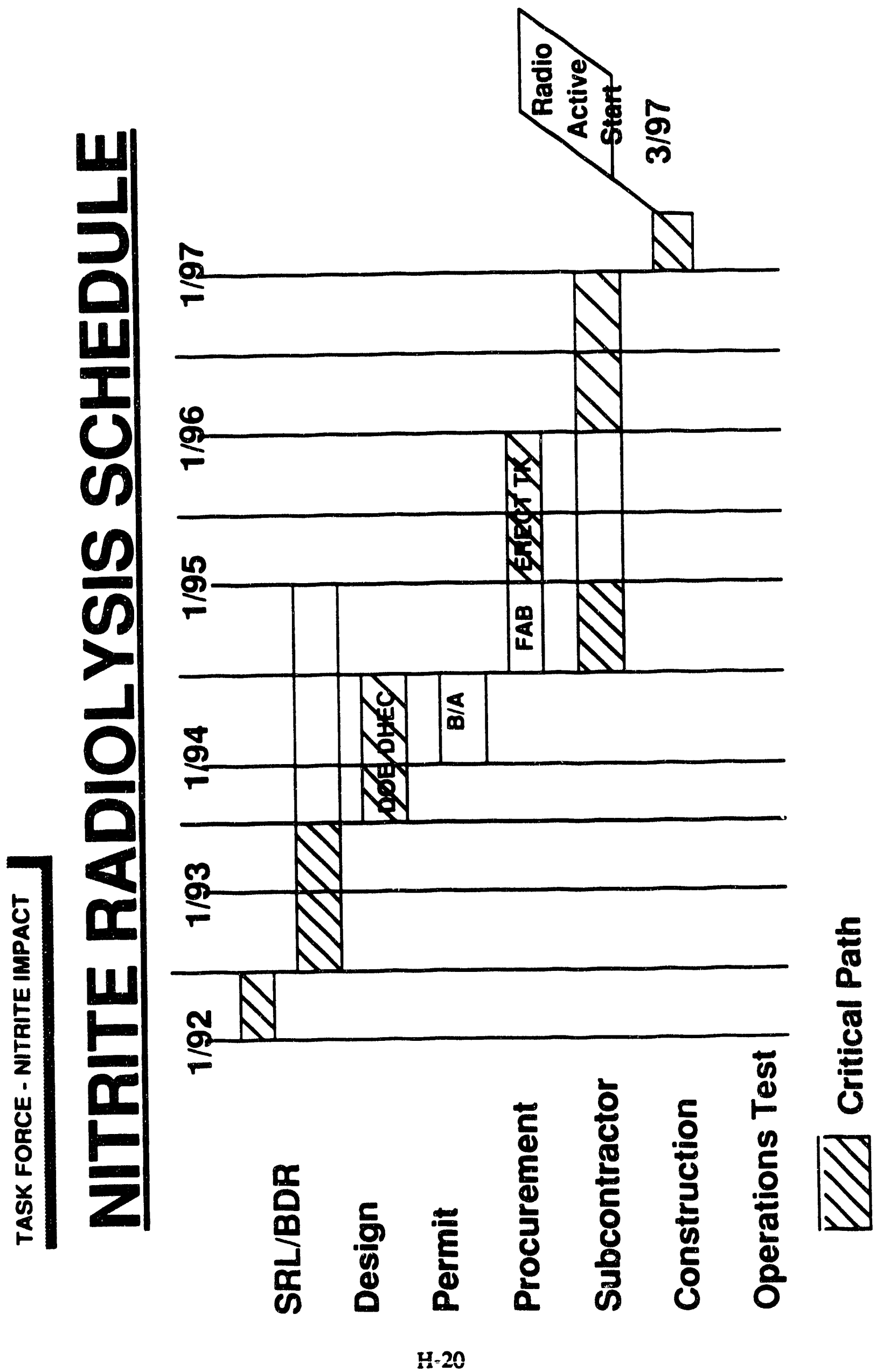


WSRC-TR-92-67

Revision 0

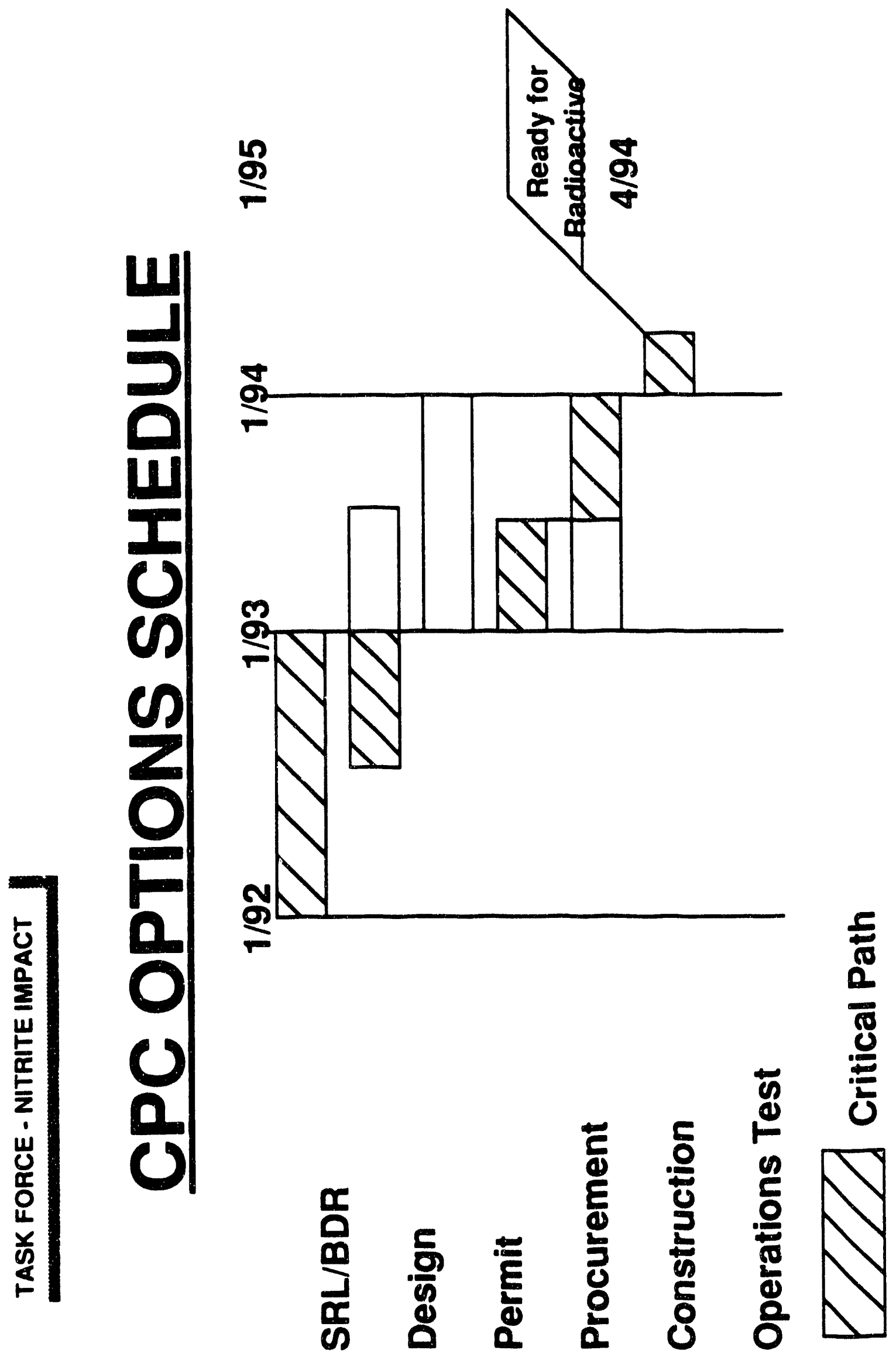



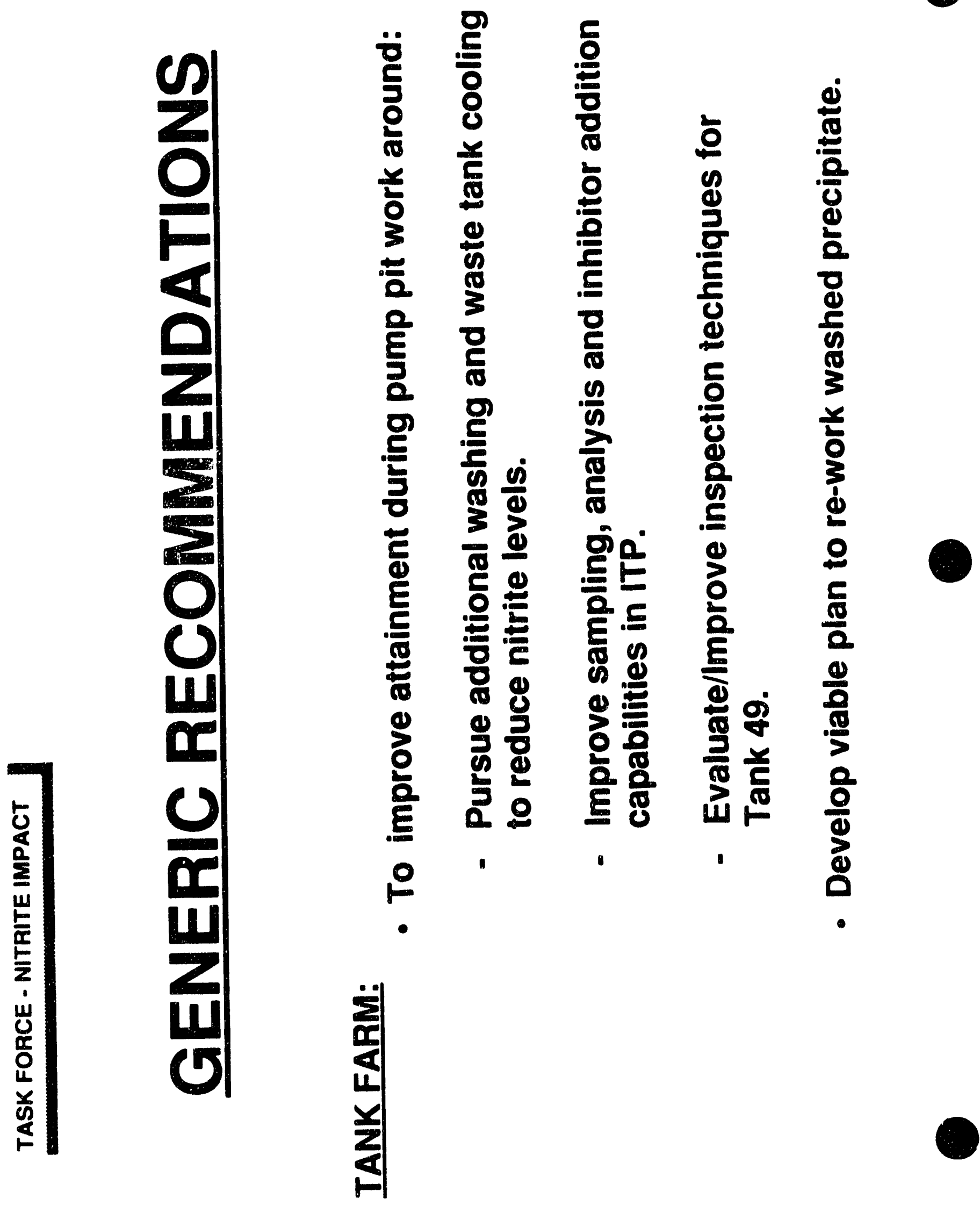


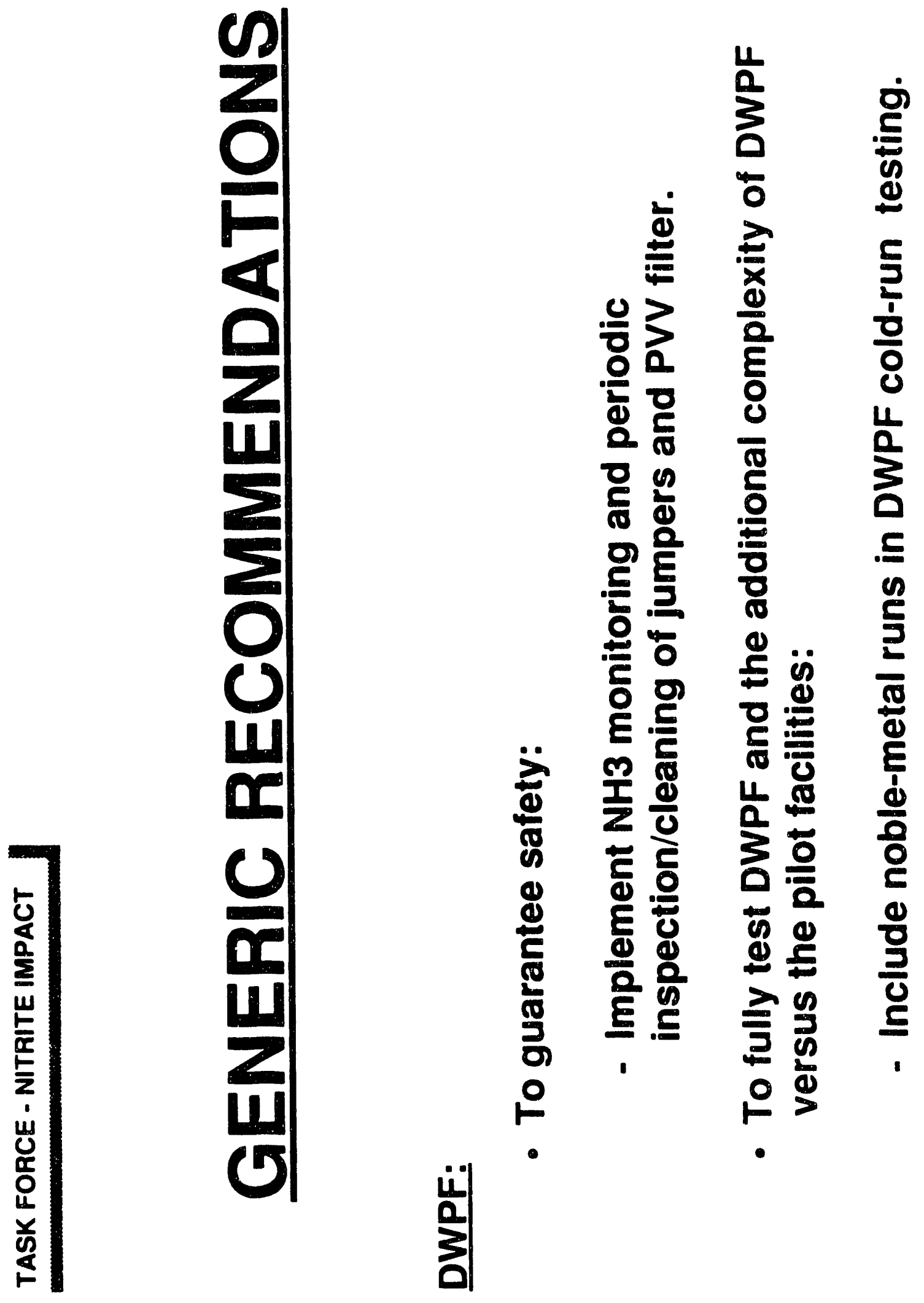



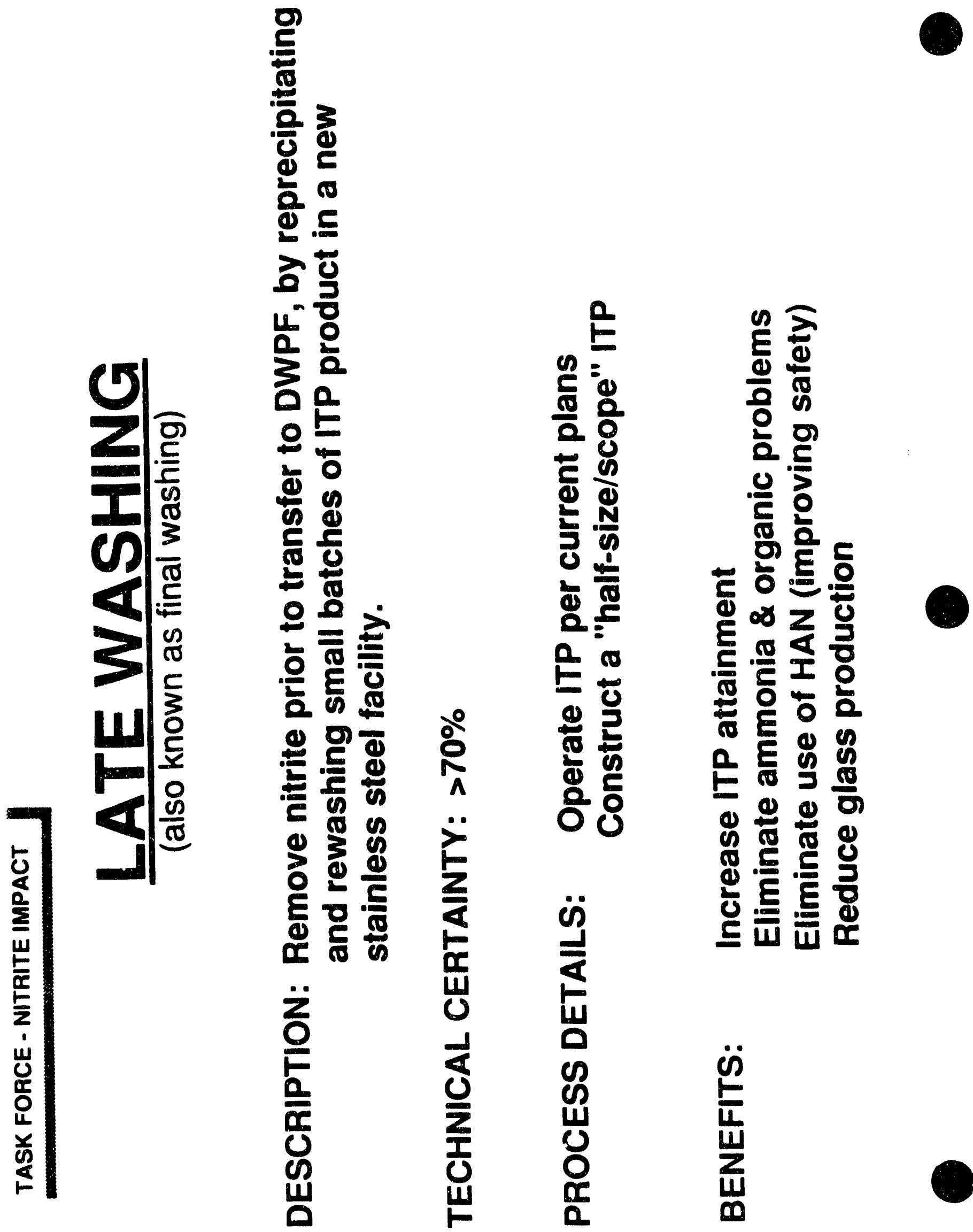


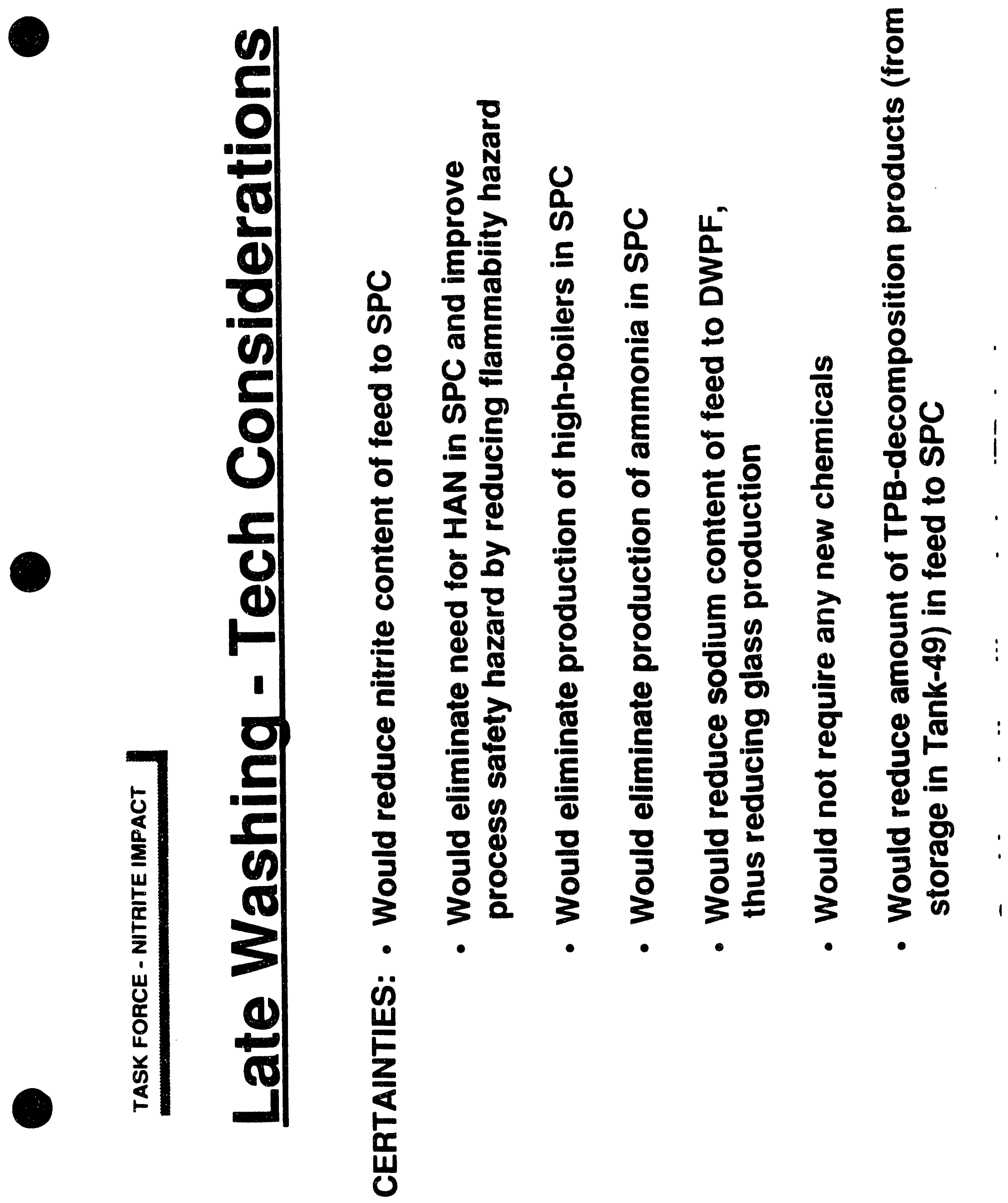




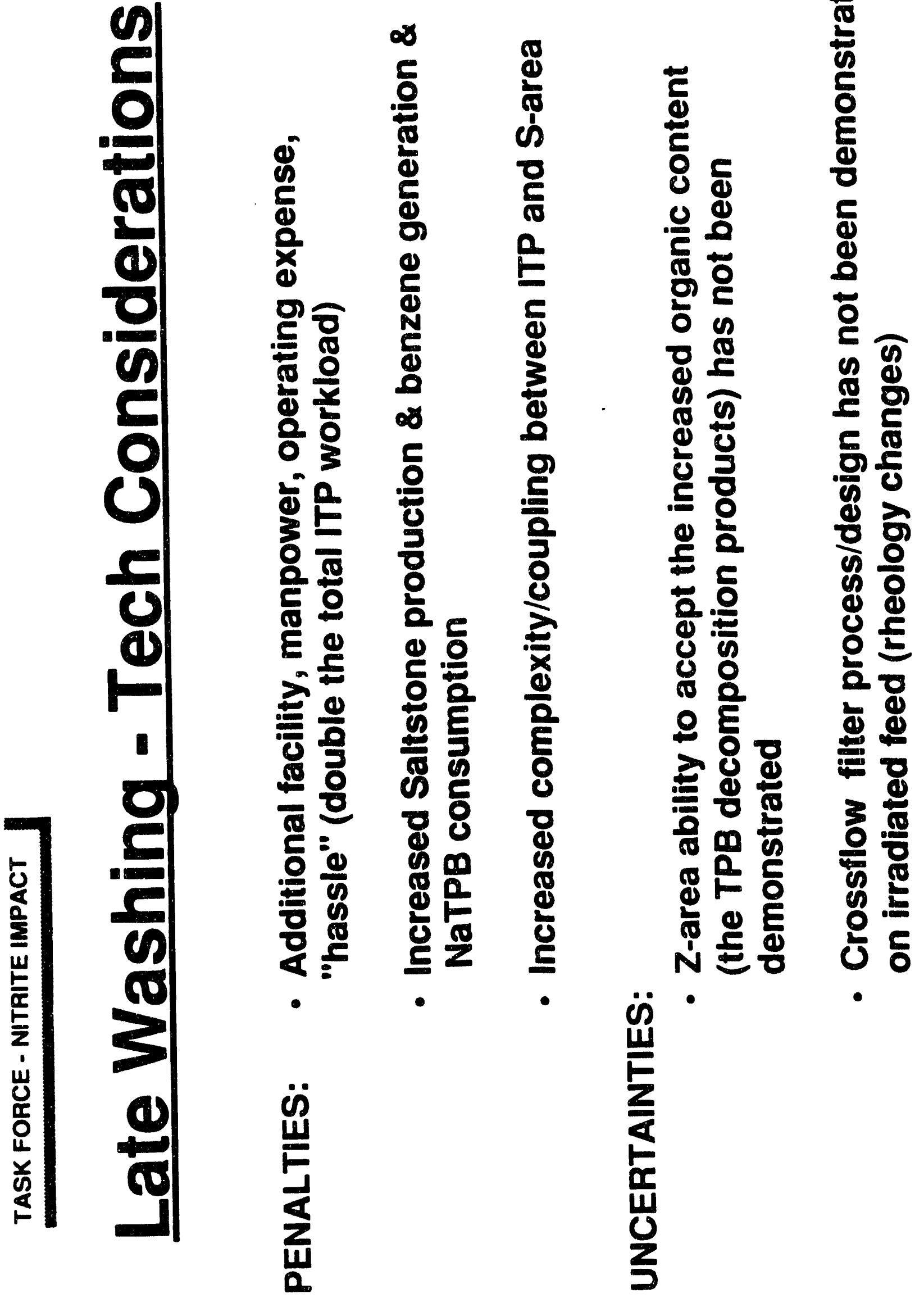

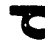

a

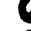


WSRC-TR-92-67

Revision 0
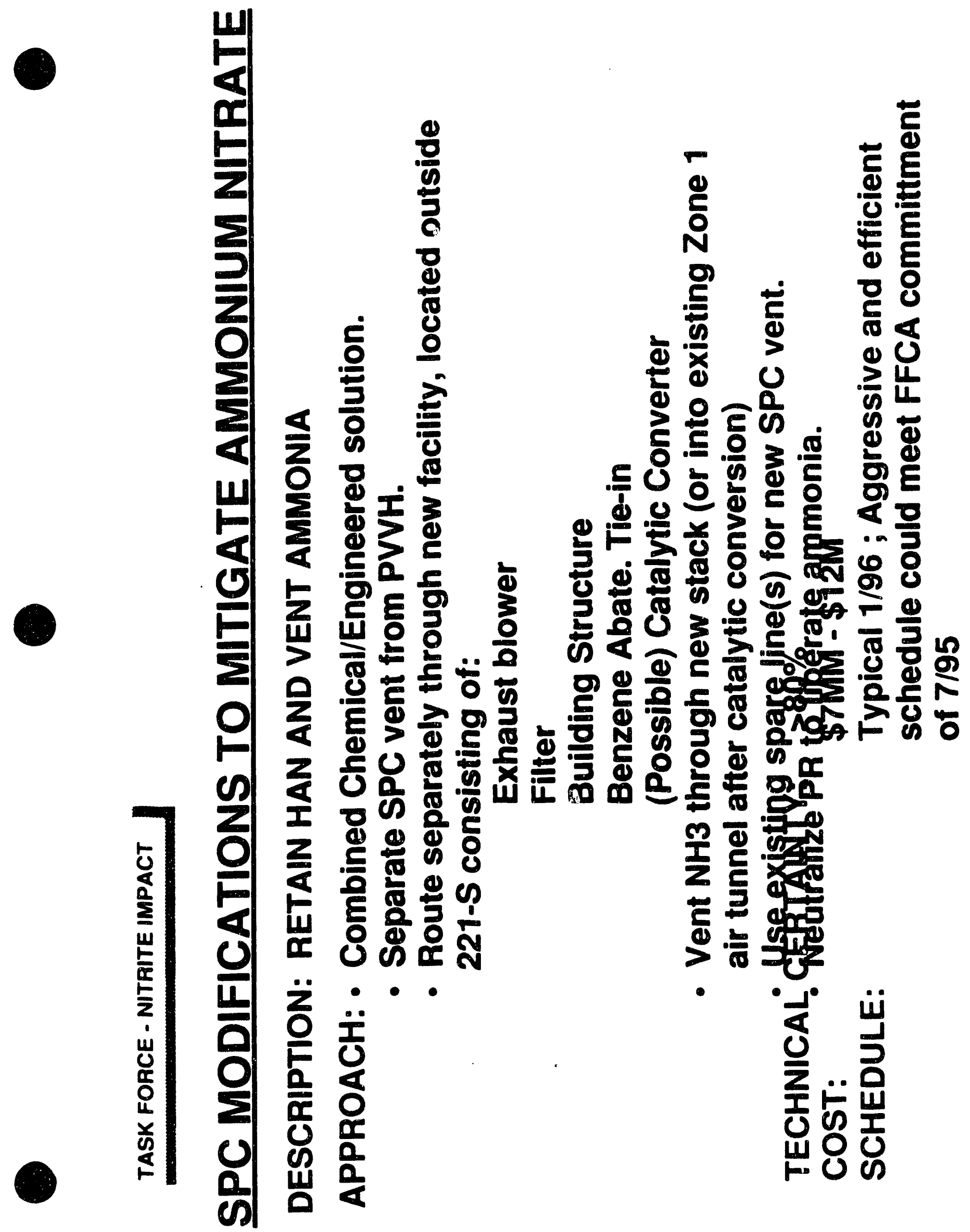


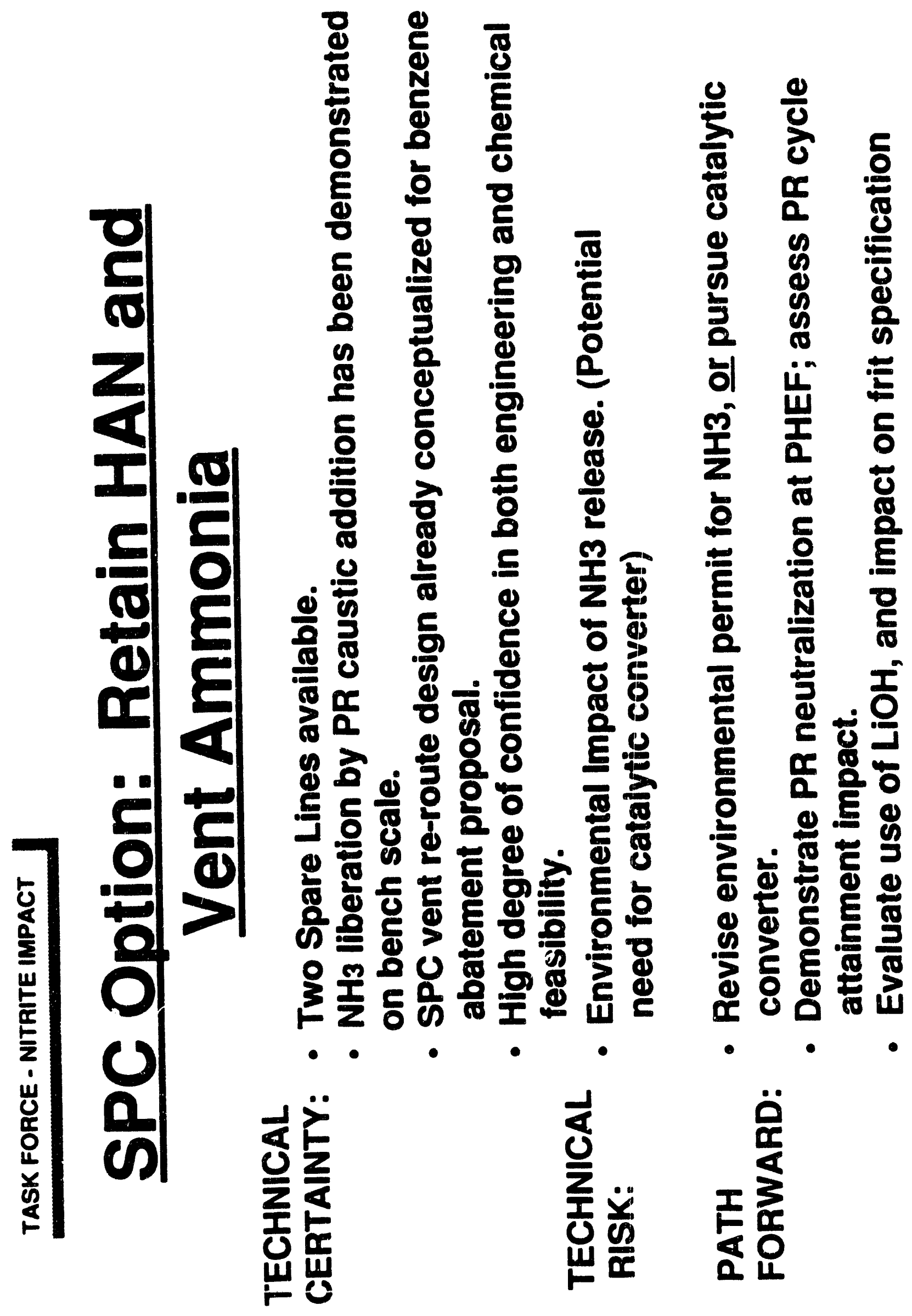



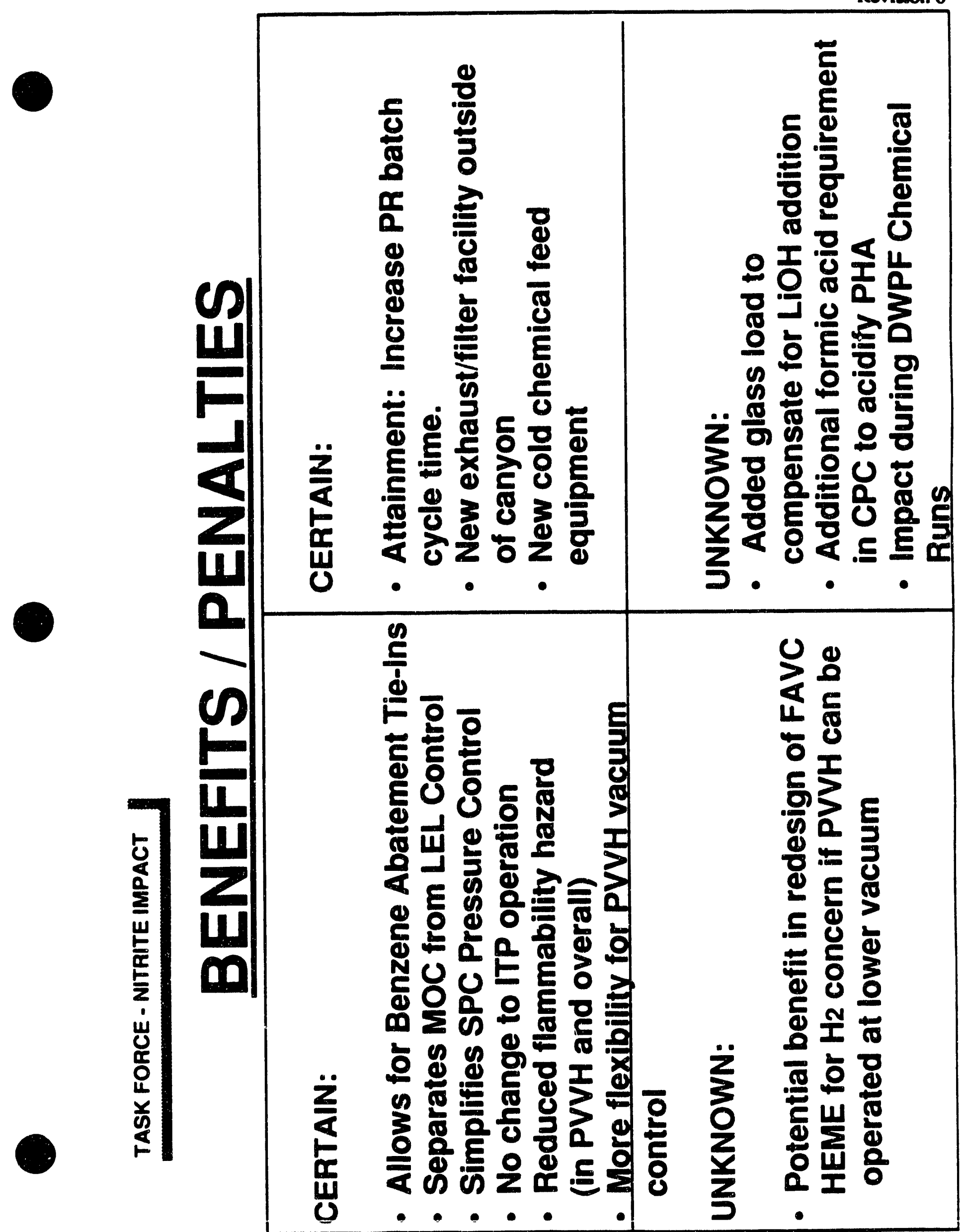

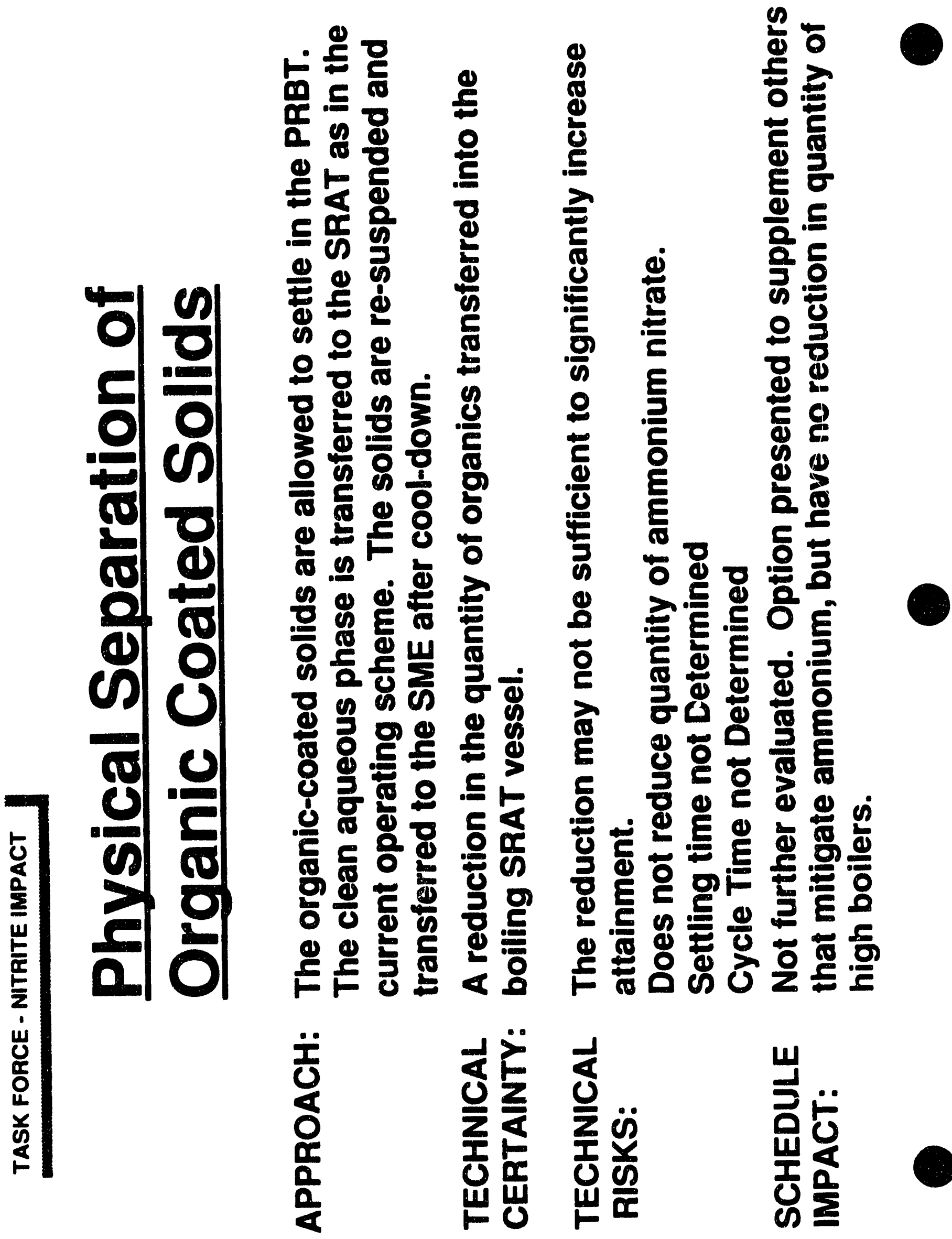


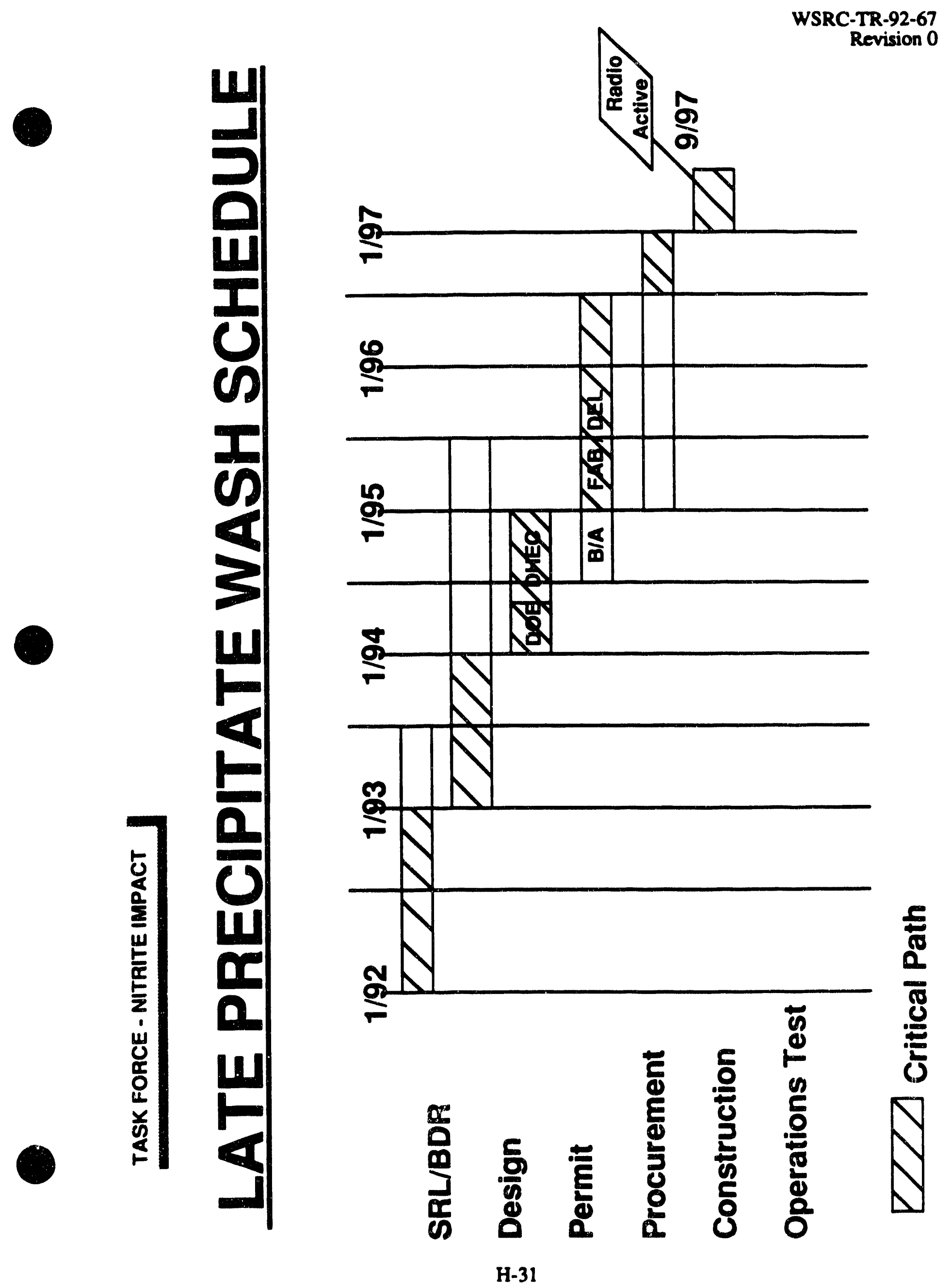




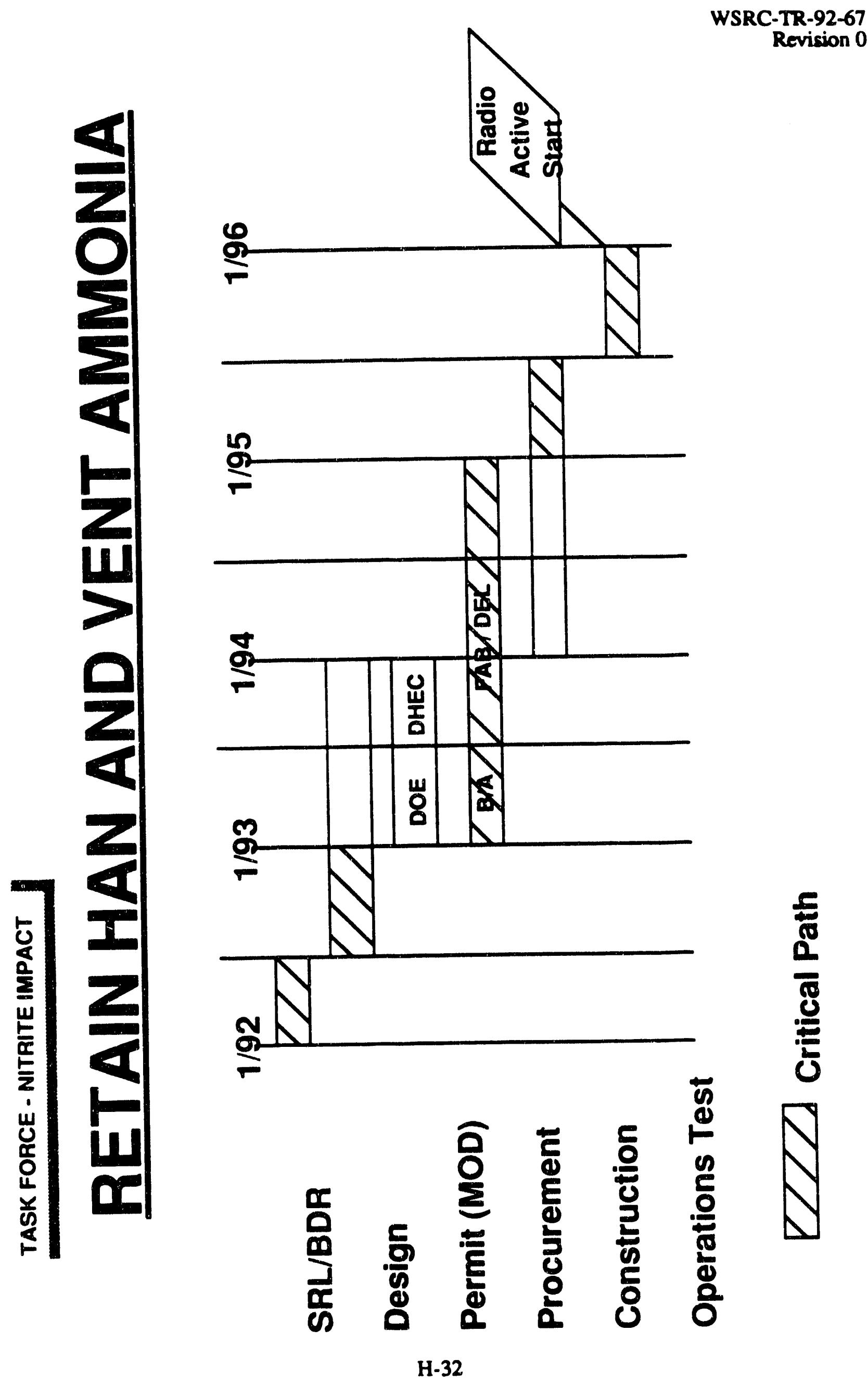




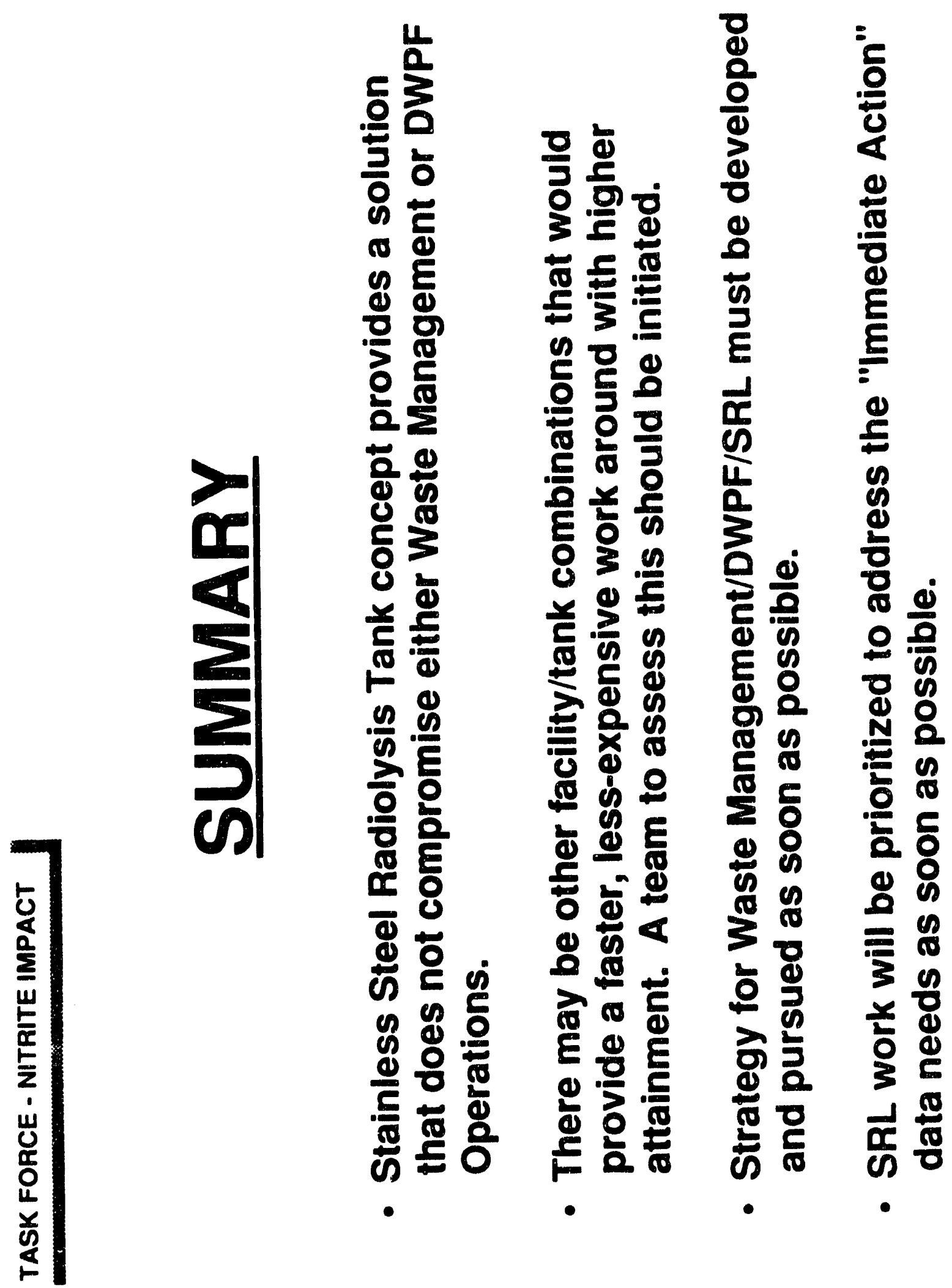




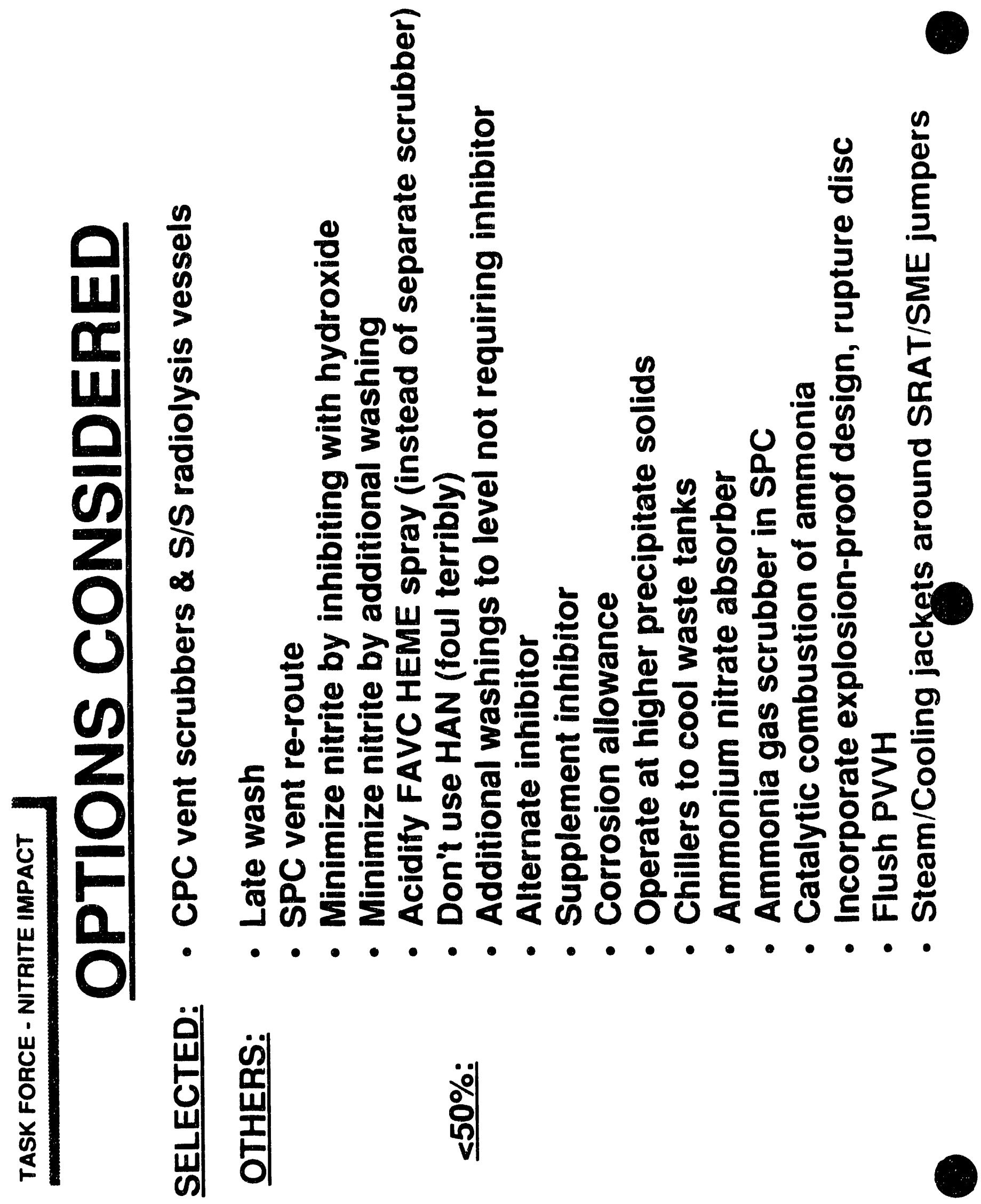


WSRC-TR-92-67

Revision 0

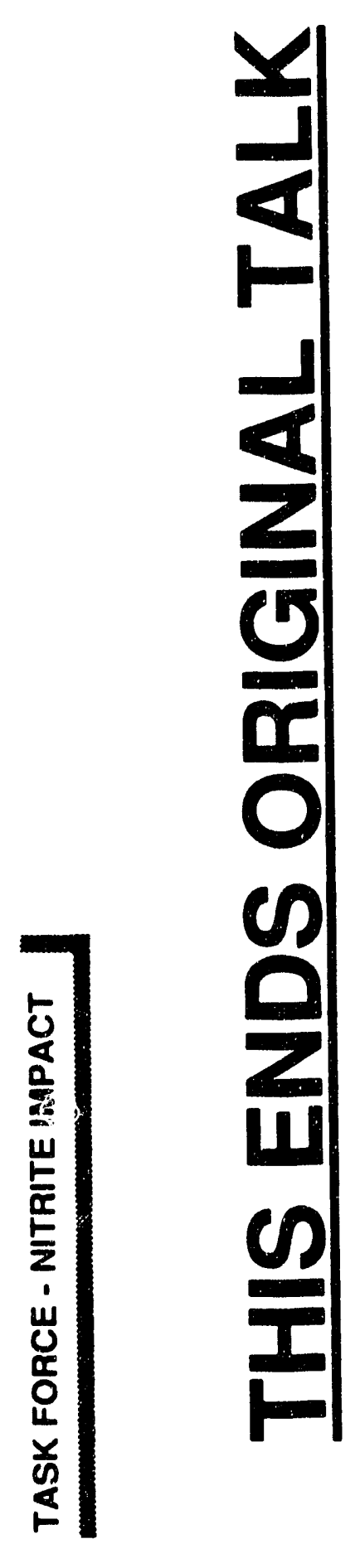

H-35 


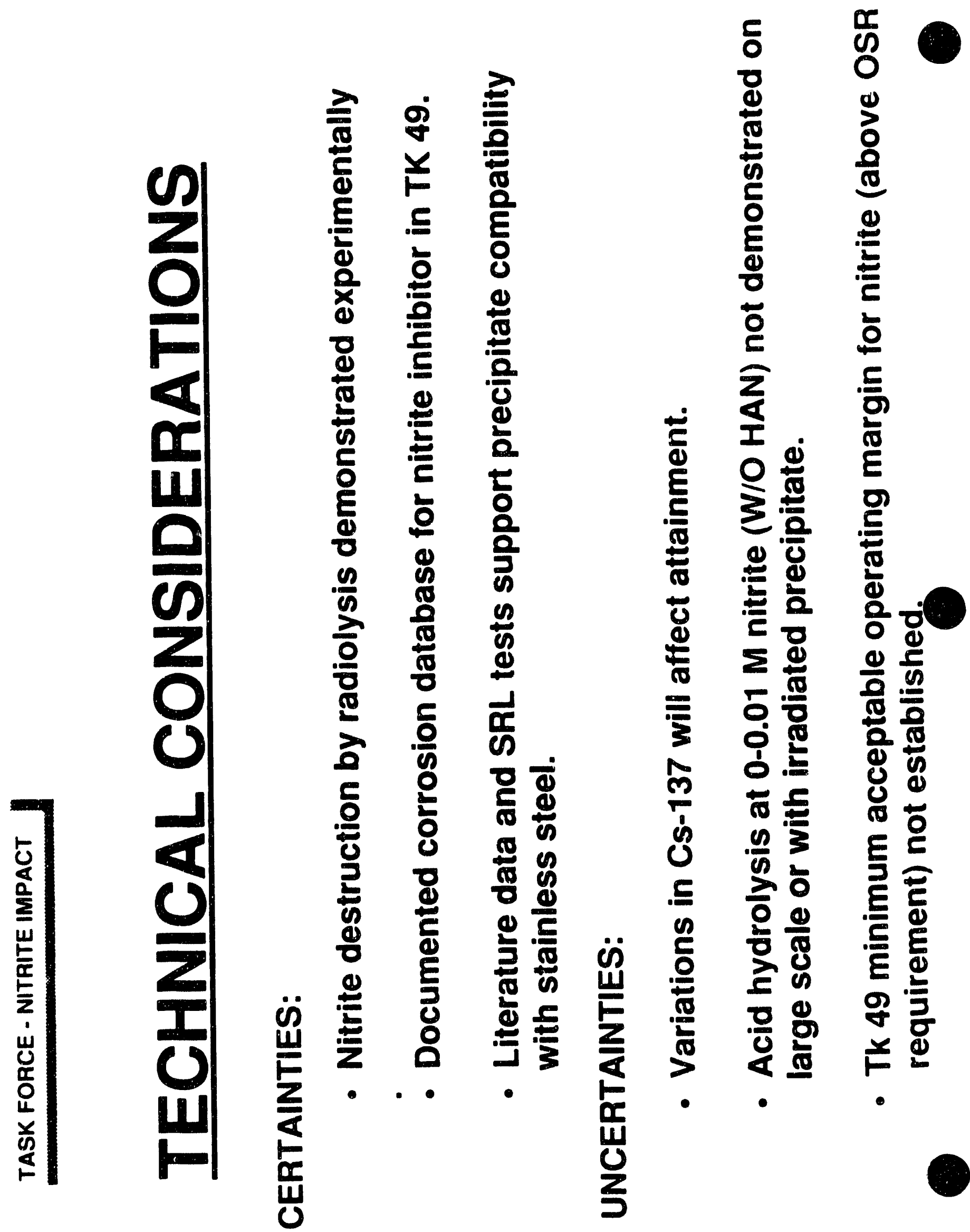




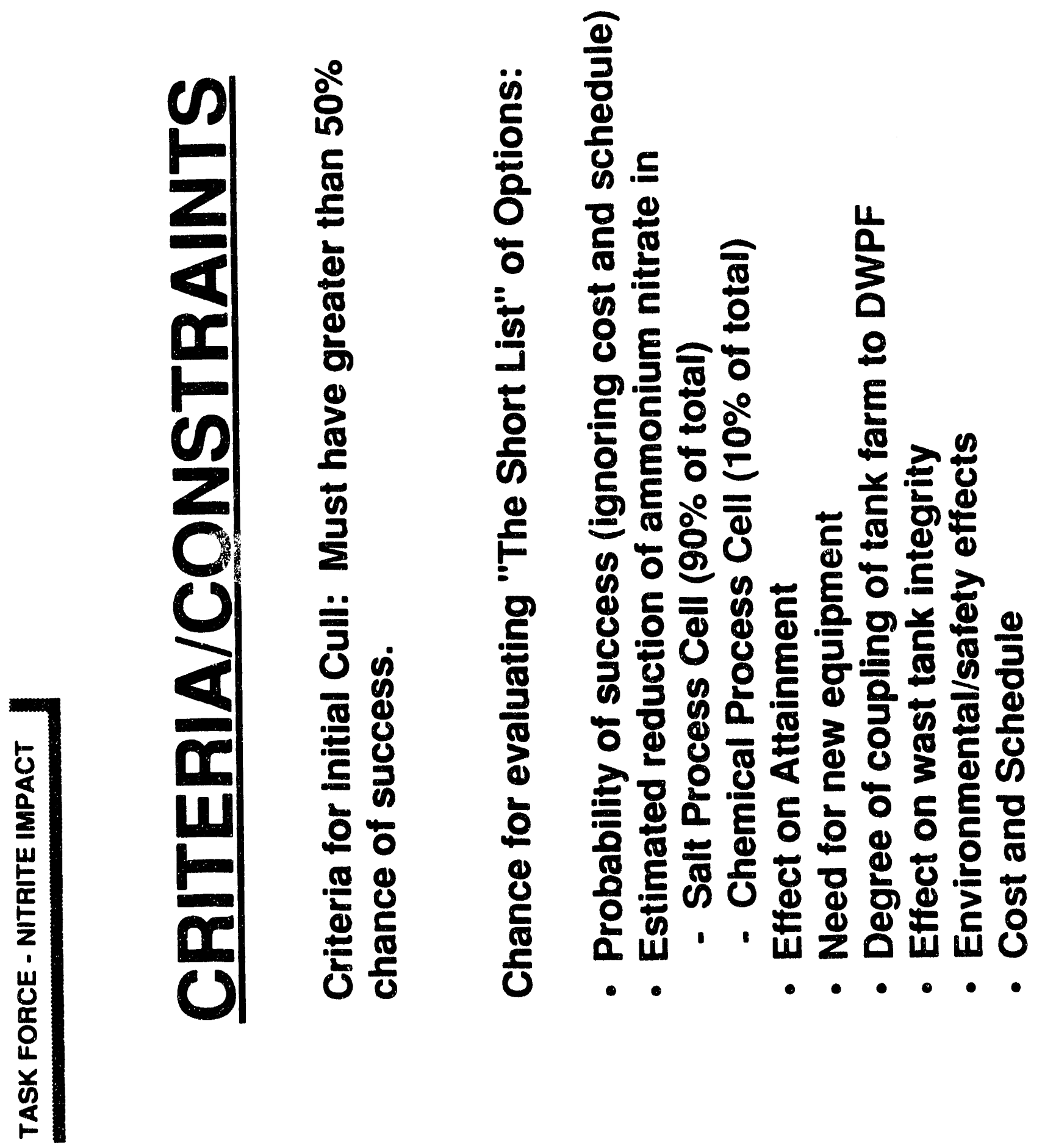


WSRC-TR-92-67

Revision 0

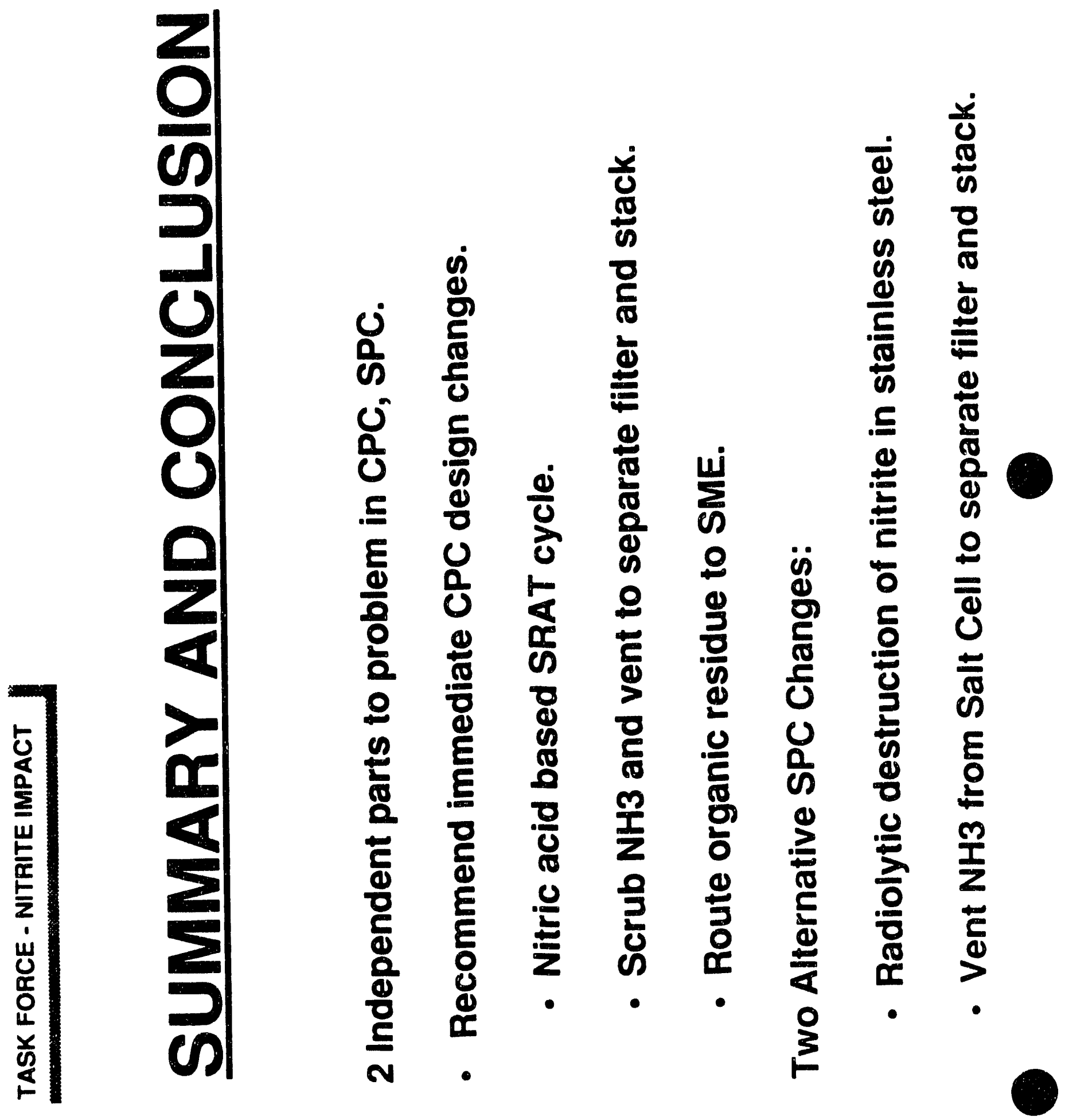


WSRC-TR-92-67

Revision 0

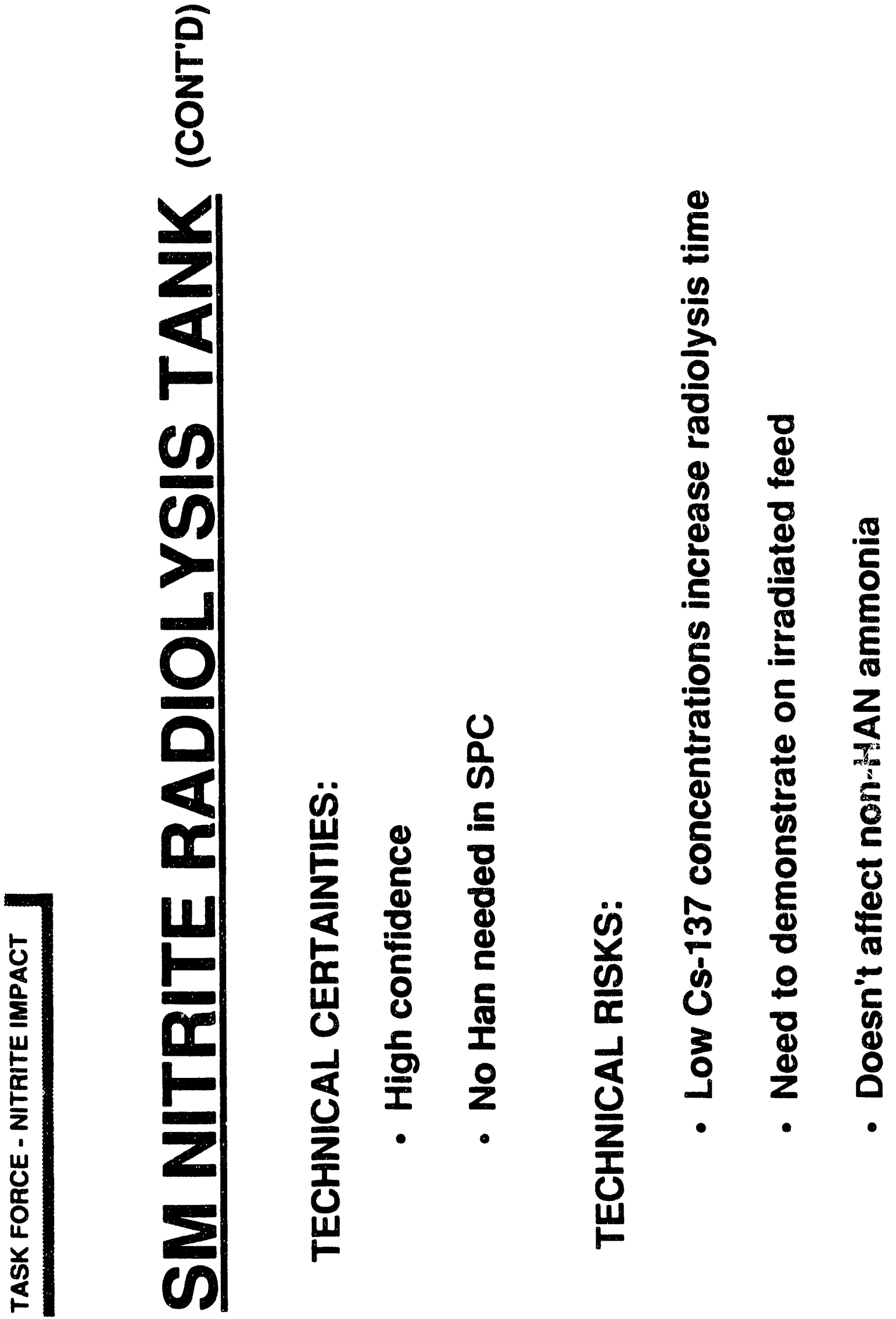




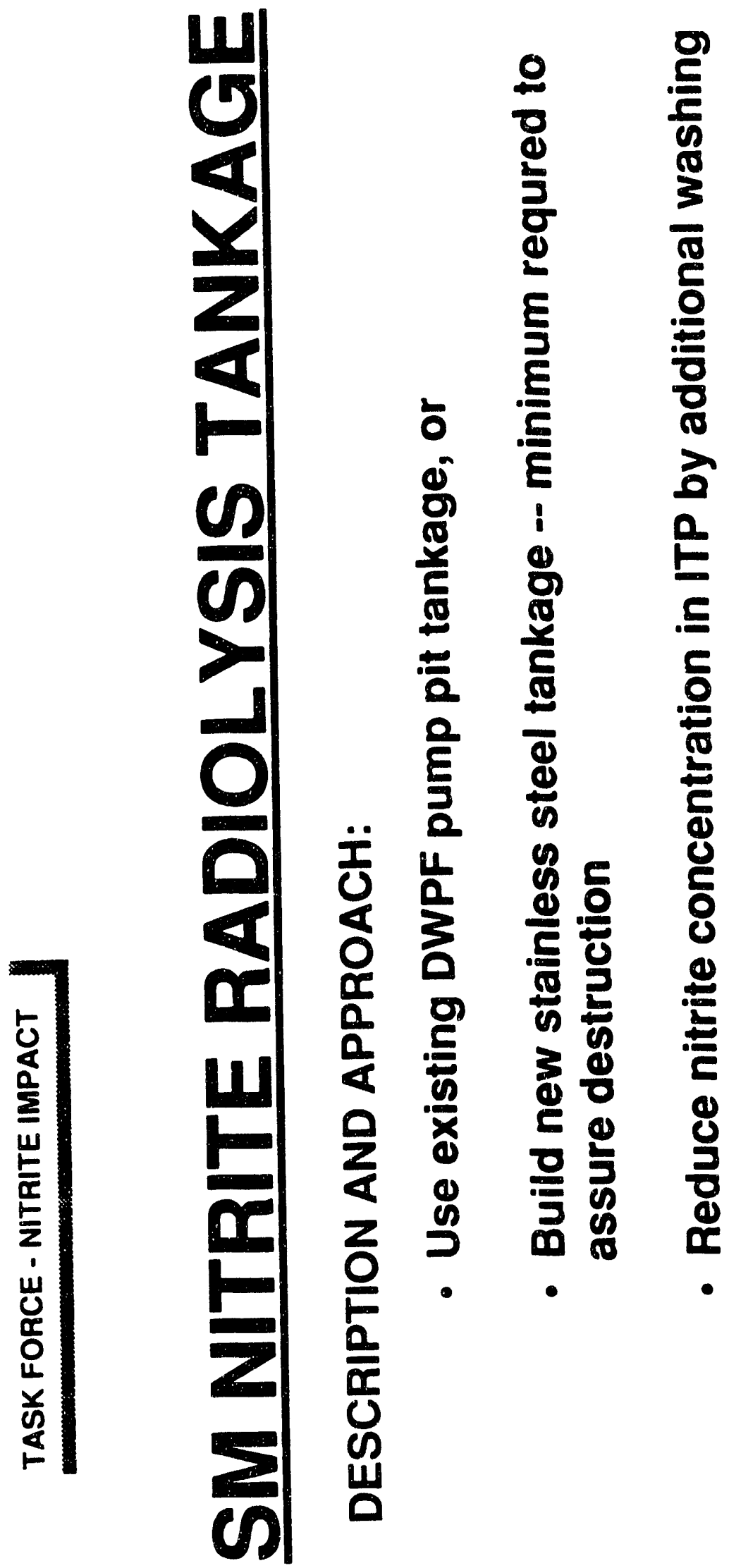

$\frac{\frac{1}{2}}{\frac{2}{2}}$

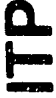

$\stackrel{0}{0}$

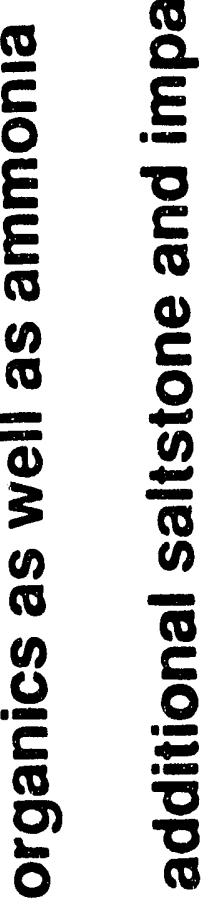

ए) 3 क

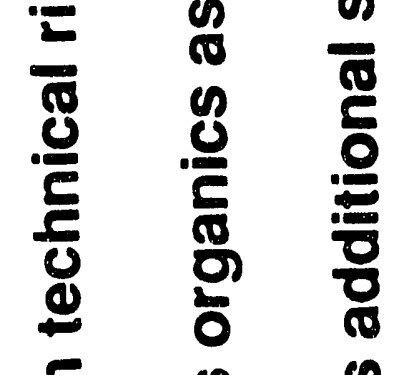

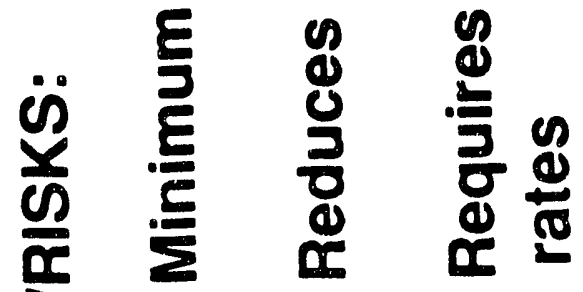


WSRC-TR-92-67

Revision 0

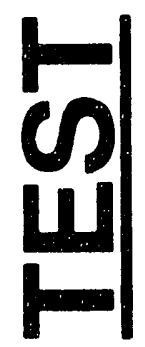

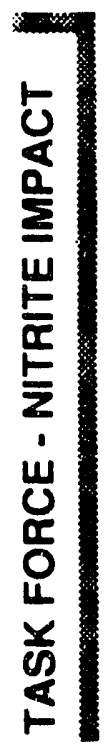


WSRC-TR-92-67

Revision 0

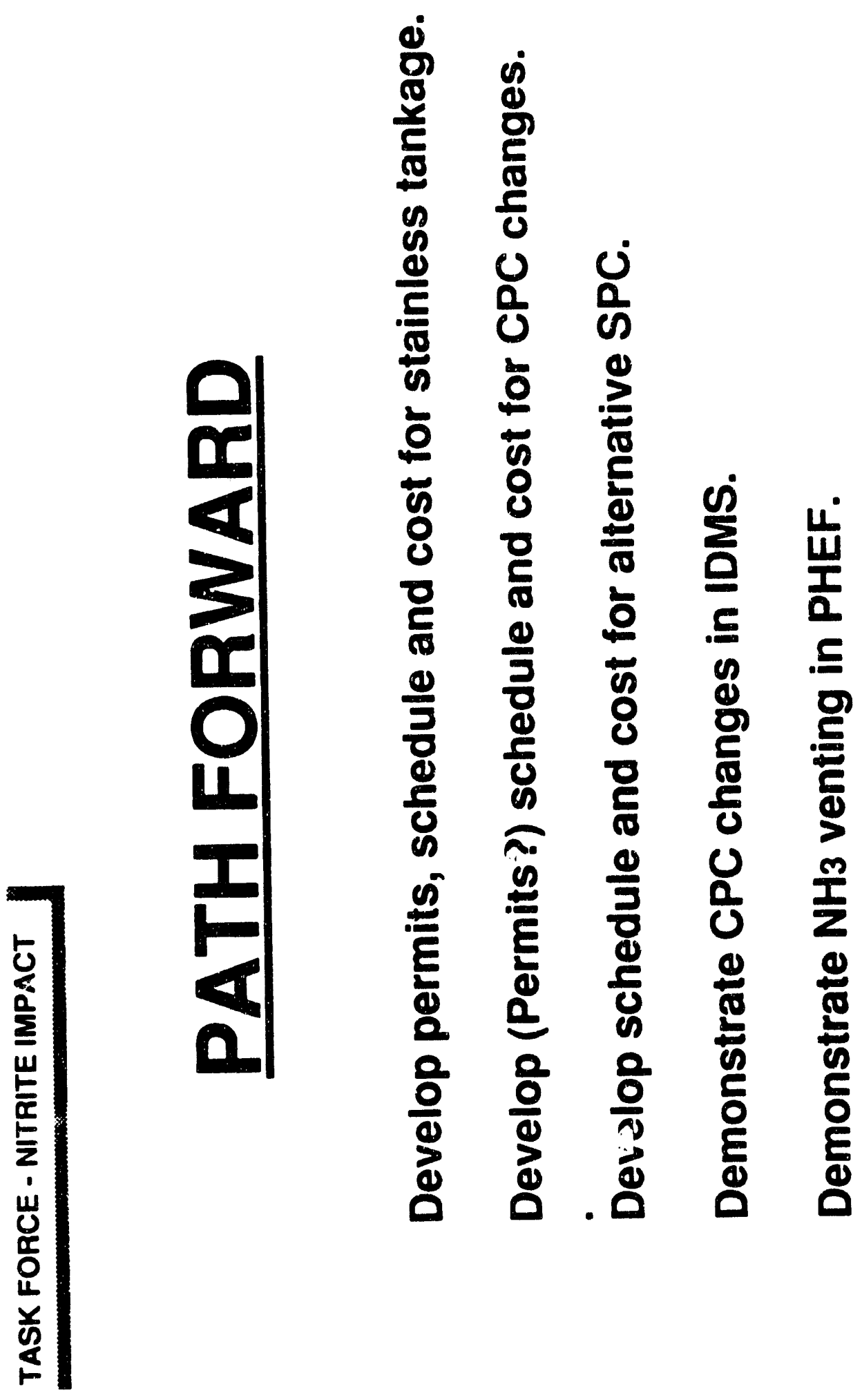


WSRC-TR-92-67

Revision 0

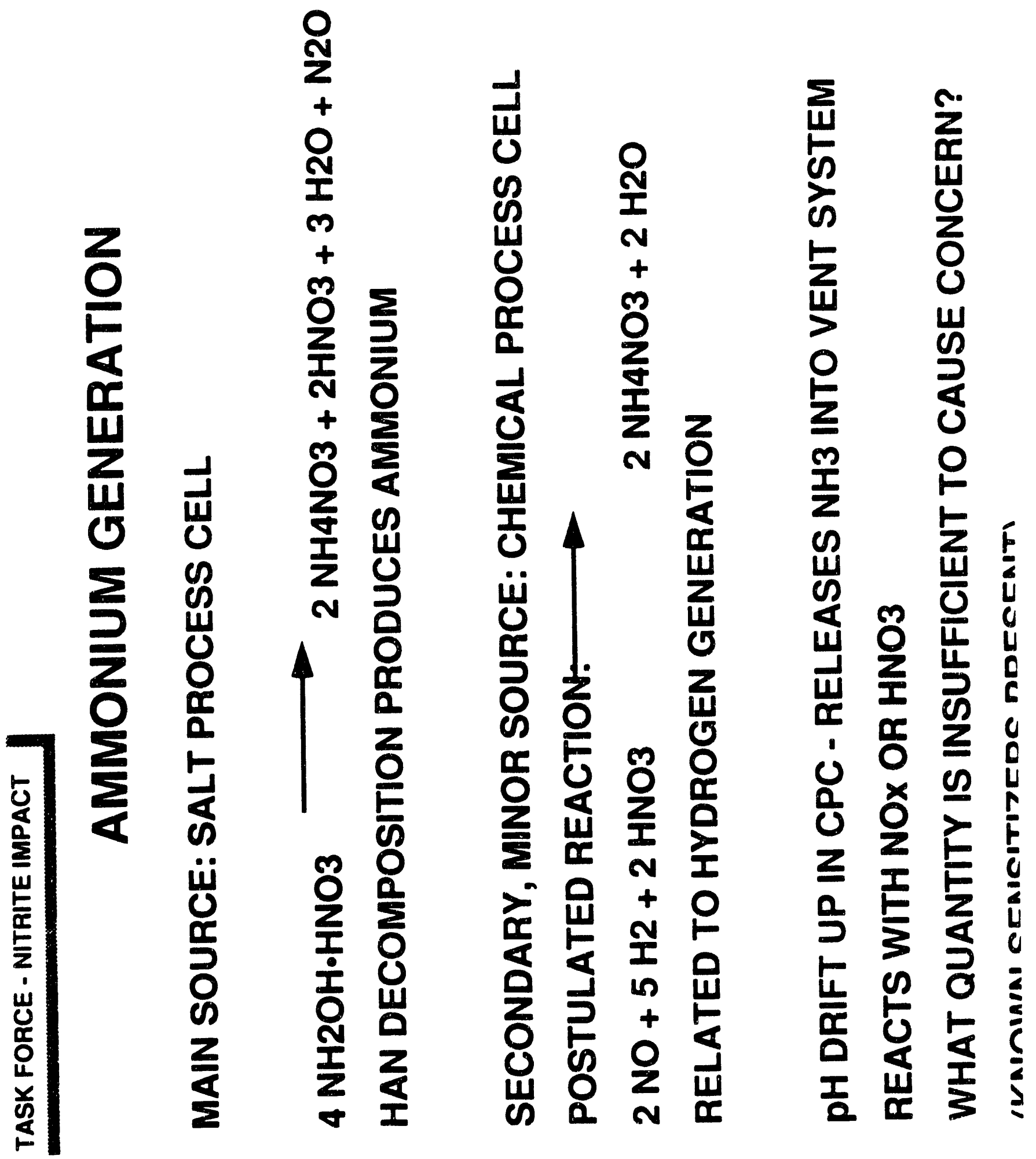




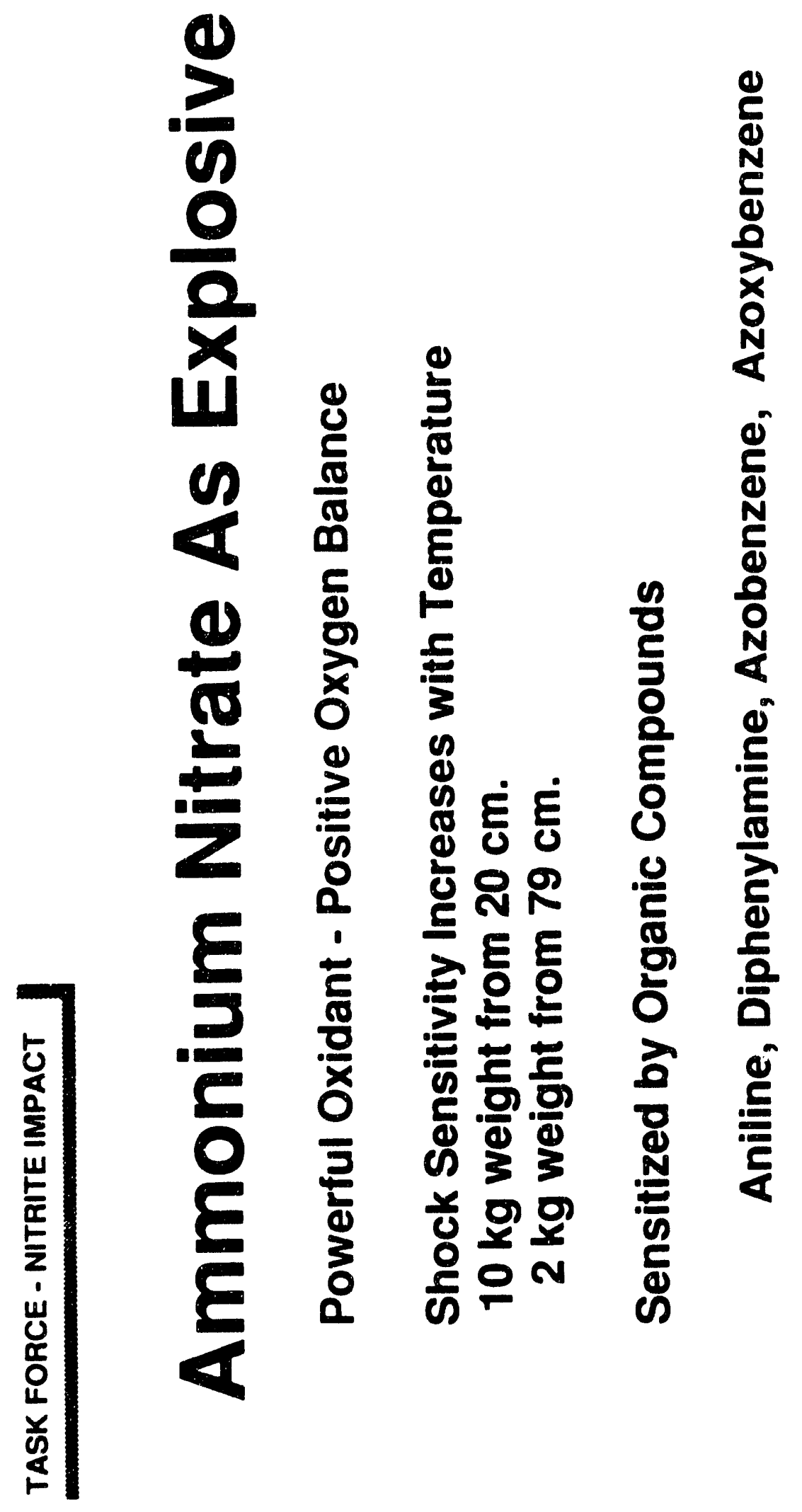

8

क

ㅎํㄴ

용 응

2 능

요요 웅

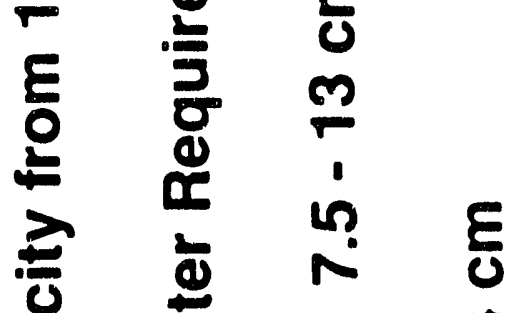

O

क E

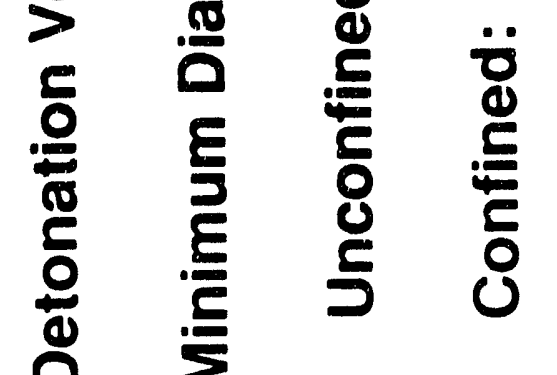


WSRC-TR-92-67

Revision 0

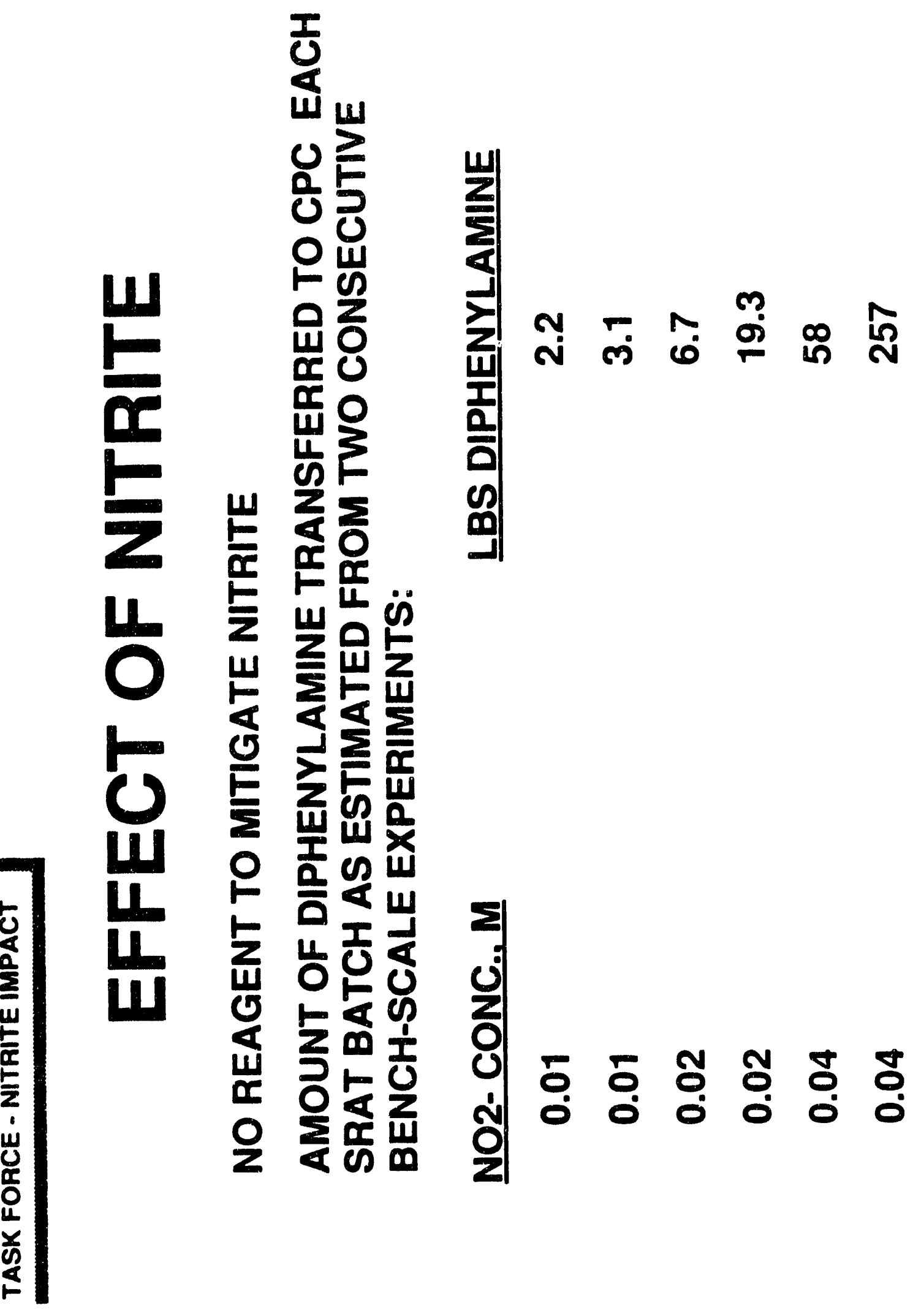




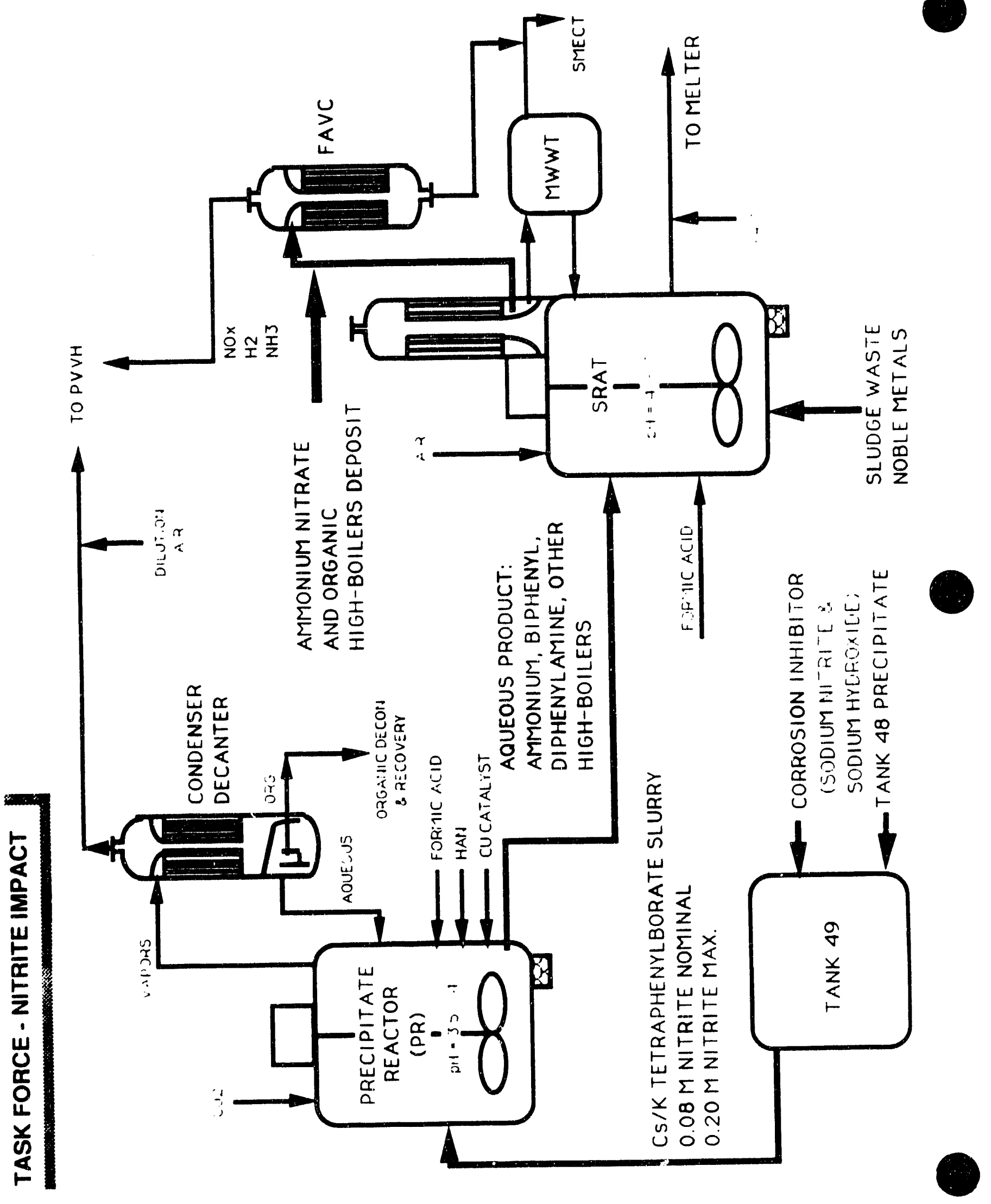


WSRC-TR-92-67

Revision 0

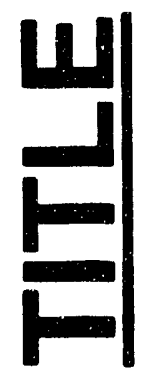

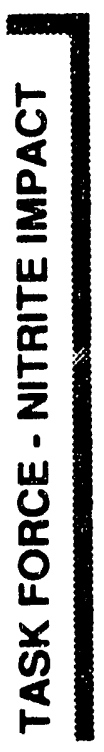


WSRC-TR-92-67

Revision 0

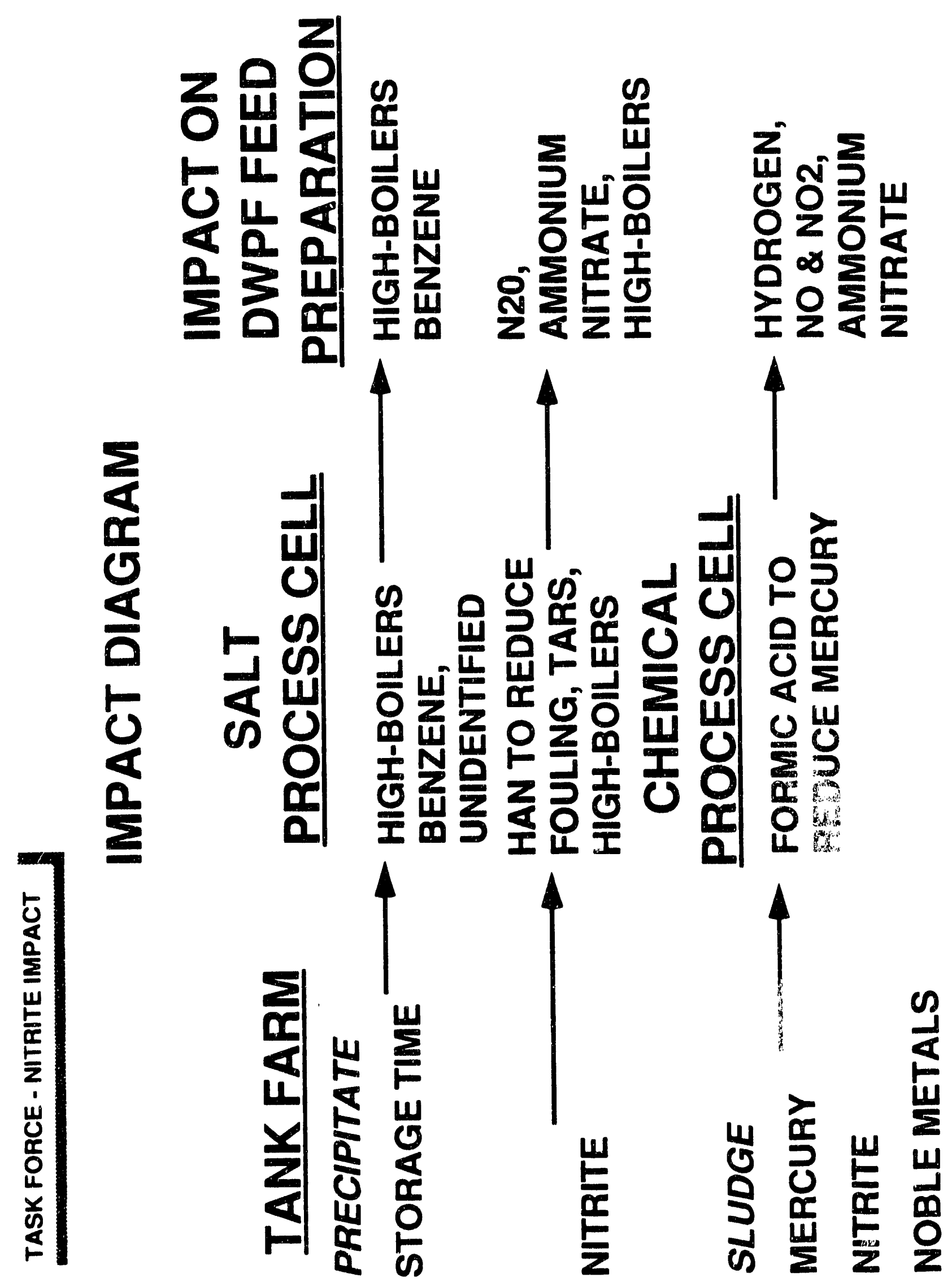




\begin{tabular}{|c|c|}
\hline $\begin{array}{l}\text { CAA } \\
\text { CIF } \\
\text { CPC } \\
\text { CPES } \\
\text { CsTPB }\end{array}$ & $\begin{array}{l}\text { Federal Clean Air Act } \\
\text { Consolidated Incineration Facility } \\
\text { Chemical Process Cell } \\
\text { Chemical Process Evaluation System } \\
\text { Cesium Tetraphenylborate, }\left(\mathrm{C}_{6} \mathrm{H}_{5}\right)_{4} \mathrm{BCs}\end{array}$ \\
\hline $\begin{array}{l}\text { DHEC } \\
\text { DWPF }\end{array}$ & $\begin{array}{l}\text { see SCDHEC } \\
\text { Defense Waste Processing Facility }\end{array}$ \\
\hline $\begin{array}{l}\text { EPA } \\
\text { ESP }\end{array}$ & $\begin{array}{l}\text { U.S. Environmental Protection Agency } \\
\text { Extended Sludge Processing }\end{array}$ \\
\hline $\begin{array}{l}\text { FAVC } \\
\text { FFCA }\end{array}$ & $\begin{array}{l}\text { Formic Acid Vent Condenser } \\
\text { Federal Facilities Compliance Act }\end{array}$ \\
\hline $\begin{array}{l}\text { HAN } \\
\text { HEME }\end{array}$ & $\begin{array}{l}\text { Hydroxylamine Nitrate, } \mathrm{NH}_{2} \mathrm{OH} \cdot \mathrm{HNO}_{3} \\
\text { High-Efficiency Mist Eliminator }\end{array}$ \\
\hline $\begin{array}{l}\text { IDMS } \\
\text { IPHS } \\
\text { ITP }\end{array}$ & $\begin{array}{l}\text { Integrated DWPF Melter System (at TNX) } \\
\text { Integrated Precipitate Hydrolysis System } \\
\text { In-Tank (Precipitation) Process }\end{array}$ \\
\hline КTPB & Potassium Tetraphenylborate, $\left(\mathrm{C}_{6} \mathrm{H}_{5}\right)_{4} \mathrm{BK}$ \\
\hline LEL & Lower Explosive Limit \\
\hline $\begin{array}{l}\text { MFT } \\
\text { MOC }\end{array}$ & $\begin{array}{l}\text { Melter Feed Tank } \\
\text { Minimum Oxidant Concentration (for combustion) }\end{array}$ \\
\hline NaTPB & Sodium Tetraphenylborate, $\left(\mathrm{C}_{6} \mathrm{H}_{5}\right) \mathrm{BNa}$ \\
\hline $\begin{array}{l}\text { OE } \\
\text { OECD } \\
\text { OECT } \\
\text { OSHA } \\
\text { OWST }\end{array}$ & $\begin{array}{l}\text { Organic Evaporator } \\
\text { Organic Evaporator Condenser-Decanter } \\
\text { Organic Evaporator Condensate Tank } \\
\text { U.S. Occupational Safety and Health Administration } \\
\text { Organic Waste Storage Tank }\end{array}$ \\
\hline $\begin{array}{l}\text { PBA } \\
\text { PHA } \\
\text { PHEF } \\
\text { PHP } \\
\text { PR } \\
\text { PRBT } \\
\text { PRC } \\
\text { PRCD } \\
\text { PRFT }\end{array}$ & $\begin{array}{l}\text { Phenylboric Acid, } \mathrm{C}_{6} \mathrm{H}_{5} \mathrm{~B}(\mathrm{OH})_{2} \\
\text { Precipitate Hydrolysis Aqueous product } \\
\text { Precipitate Hydrolysis Experimental Facility (at TNX) } \\
\text { Precipitate Hydrolysis Process } \\
\text { Precipitate Reactor } \\
\text { Precipitate Reactor Bottoms Tank } \\
\text { Precipitate Reactor Condenser (in the PHEF) } \\
\text { Precipitate Reactor Condenser-Decanter } \\
\text { Precipitate Reactor Feed Tank }\end{array}$ \\
\hline
\end{tabular}


PVVF

PVVH

RCT

$S$ Area

SCDHEC

SCVC

SME

SMECT

SPC

SRAT

SRL

SRP

SRS

SRTC

TNX

TOC

TPB

UEL

Z Area
Process Vessel Vent Filter

Process Vessel Vent Header

Recycle Collection Tank

SRS Vitrification Facility (DWPF)

South Carolina Department of Health and Environmental Control

Salt Cell Vent Condenser

Slurry Mix Evaporator

Slurry Mix Evaporator Condensate Tank

Salt Process Cell

Sludge'Receipt and Adjustment Tank

Savannah River Laboratory

Savannah River Plant

Savannah River Site

Savannah River Technology Center (new name for SRL 4/1/92)

SRL's Semiworks Experimental Facility (in the 400 Area)

Total Organic Carbon (aromatic carbon + formate carbon)

Tetraphenylborate, $\left(\mathrm{C}_{6} \mathrm{H}_{5}\right)_{4} \mathrm{~B}^{-}$

Upper Explosive Limit

Saltstone Facility 

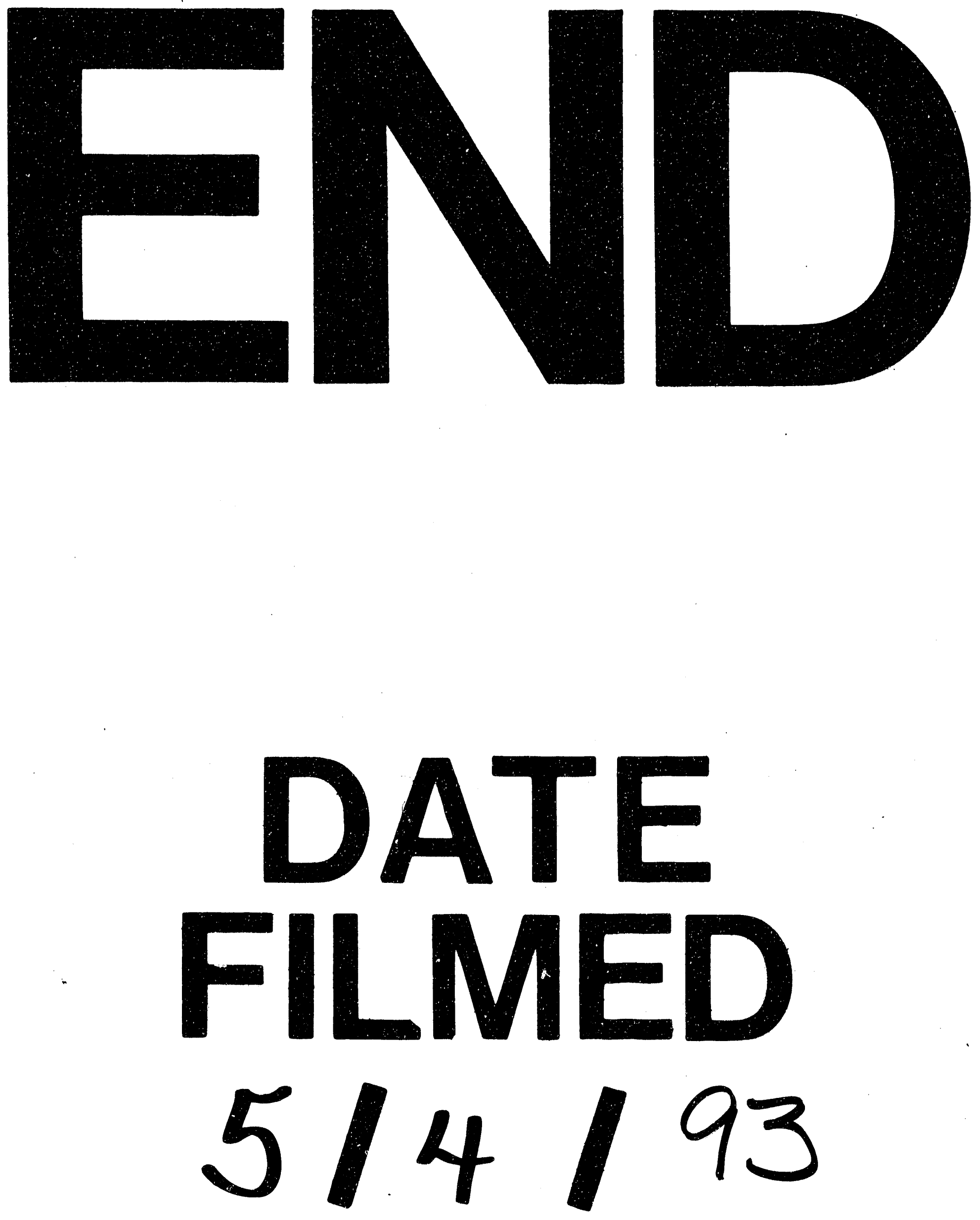
